\title{
Annual Report to Congress on \\ Federal Government Energy Management and Conservation Programs \\ Fiscal Year 1997
}

August 13, 1999

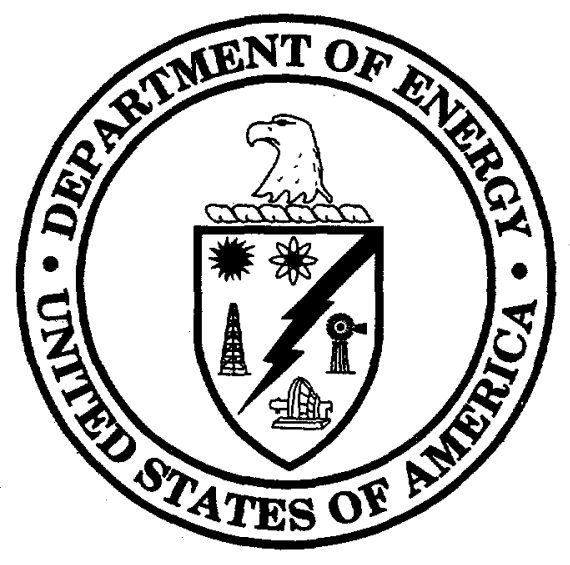

U.S. Department of Energy

Assistant Secretary, Energy Efficiency and Renewable Energy

Federal Energy Management Program

Washington, DC 20585 


\section{DISCLAIMER}

This report was prepared as an account of work sponsored by an agency of the United States Government. Neither the United States Government nor any agency thereof, nor any of their employees, make any warranty, express or implied, or assumes any legal liability or responsibility for the accuracy, completeness, or usefulness of any information, apparatus, product, or process disclosed, or represents that its use would not infringe privately owned rights. Reference herein to any specific commercial product, process, or service by trade name, trademark, manufacturer, or otherwise does not necessarily constitute or imply its endorsement, recommendation, or favoring by the United States Government or any agency thereof. The views and opinions of authors expressed herein do not necessarily state or reflect those of the United States Government or any agency thereof. 


\section{DISCLAIMER}

Portions of this document may be illegible in electronic image products. Images are produced from the best available original document. 


\section{TABLE OF CONTENTS}

EXECUTIVE SUMMARY $\ldots \ldots \ldots \ldots \ldots \ldots \ldots \ldots \ldots \ldots \ldots \ldots \ldots \ldots$

I. OVERVIEW OF FEDERAL ENERGY MANAGEMENT ACTIVITIES ..7

A. Overview of Federal Energy Management Policy and

Legislative Mandates ......................... 7

B. Overall Federal Energy Consumption, Costs, and Carbon Emissions ... 10

C. Federal Coordination ........................... 17

D. Personnel and Energy Awareness Activities ............... 19

- Training ..................................... 19

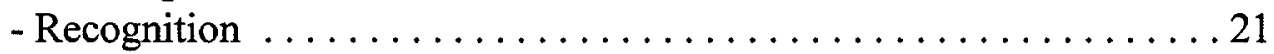

- Energy Awareness ............................24

- Federal Energy Saver Showcase Facilities $\ldots \ldots \ldots \ldots \ldots \ldots . .25$

E. Funding for Energy Efficiency in Buildings and Facilities . . . . . . . 227

- Direct Appropriations . ........................... 27

- Federal Energy Efficiency Fund $\ldots \ldots \ldots \ldots \ldots \ldots \ldots \ldots . \ldots . \ldots . \ldots 29$

- Energy Savings Performance Contracting $\ldots \ldots \ldots \ldots \ldots \ldots \ldots . \ldots \ldots 2$

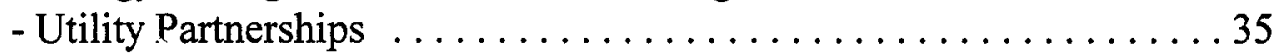

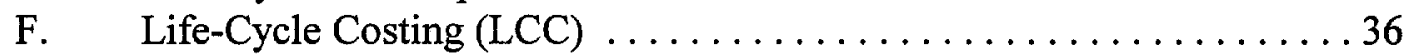

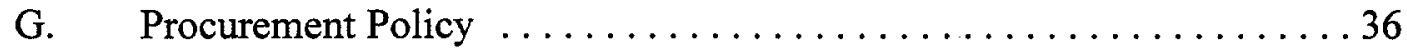

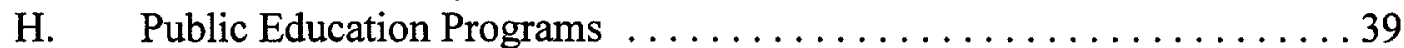

II. ENERGY MANAGEMENT IN BUILDINGS AND FACILITIES $\ldots \ldots \ldots 43$

A. Energy Consumption and Costs for Buildings and Facilities ........43

B. Progress Toward the Mandated Goals for Buildings and Facilities . . . . 51

C. Energy Star Program Participation ..................... 56

D. Federal Building Energy Performance Standards $\ldots \ldots \ldots \ldots \ldots 58$

III. ENERGY INTENSIVE OPERATIONS IN FEDERAL FACILITIES $\ldots .60$

A. Energy Consumption and Costs for Energy Intensive Operations . . . . 60

B. Statutory Background and Progress Toward Goals

for Industrial Facilities . . . . . . . . . . . . . . . . . . . . . 62

IV. ENERGY MANAGEMENT IN VEHICLES AND EQUIPMENT $\ldots \ldots \ldots 66$

A. Energy Consumption and Costs for Vehicles and Equipment ........66

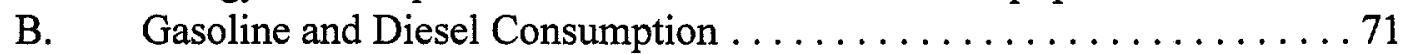

C. Alternative Fuel Vehicles . . . . . . . . . . . . . . . . . . 73

V. FEDERAL AGENCY ENERGY MANAGEMENT ACTIVITIES $\ldots \ldots \ldots 77$

1. Department of Agriculture . . . . . . . . . . . . . . . . . . . . 77

2. Department of Commerce ........................... 79

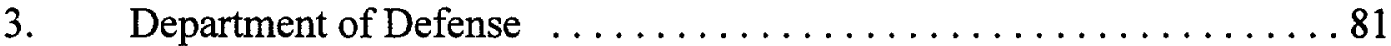

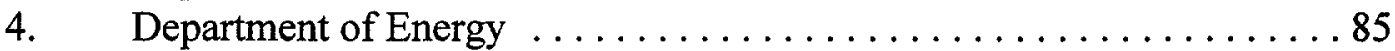

5. Department of Health and Human Services ............... 88

6. Department of Housing and Urban Development .............91 


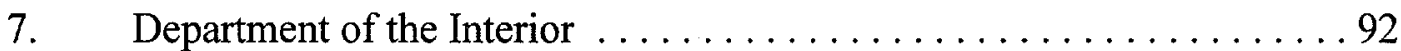

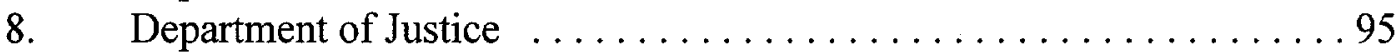

9. Department of Labor $\ldots \ldots \ldots \ldots$. . . . . . . . . . . . . . . 97

10. Department of State . . . . . . . . . . . . . . . . . . . 99

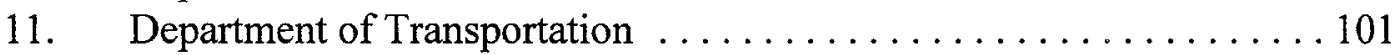

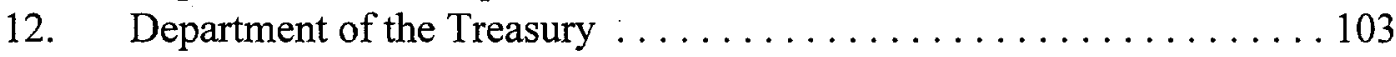

13. Department of Veterans Affairs . . . . . . . . . . . . . . . 105

14. Environmental Protection Agency . . . . . . . . . . . . . . . 107

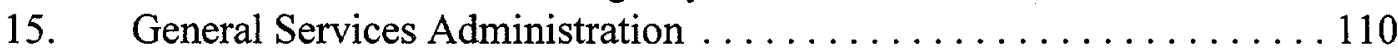

16. National Aeronautics and Space Administration . . . . . . . . . . . 113

17. National Archives and Records Administration . . . . . . . . . . . 117

18. Nuclear Regulatory Commission . . . . . . . . . . . . . 118

19. Panama Canal Commission ....................... 120

20. Railroad Retirement Board .................... 122

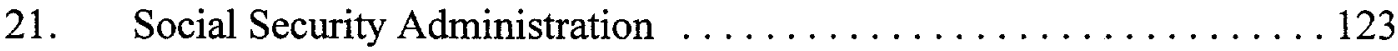

22. Tennessee Valley Authority . . . . . . . . . . . . . . . . 125

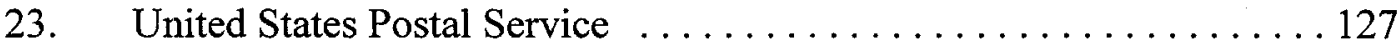

TABLES

Table 1-A

Table 1-B

Table 2

Table 3-A

Table 3-B

Table 4-A

Table 4-B

Table 5

Table 6-A

Table 6-B

Table 7-A

Table 7-B

Table 8

Table 9

Table 10

Table 11-A
Total Primary Energy Consumption By Federal Agencies $\ldots . \ldots \ldots 11$

Total Net Energy Consumption By Federal Agencies . . . . . . . . . . 12

Federal Petroleum Usage in FY $1997 \ldots \ldots \ldots \ldots$

Agency Expenditures for Energy Conservation Retrofits and Capital

Equipment, FY 1985 through FY 1997

(Thousands of Nominal Dollars) . . . . . . . . . . . . 28

Agency Expenditures for Energy Conservation Retrofits and Capital

Equipment, FY 1985 through FY 1997

(Thousands of Constant Dollars) . . . . . . . . . . . . . . 28

Federal Primary Energy Consumption in Buildings and Facilities . . . . 44

Federal Net Energy Consumption in Buildings and Facilities . . . . . . 45

Petroleum-Based Fuel Consumption in Buildings and Facilities . . . . 48

Defense and Civilian Federal Costs for Buildings Energy in FY 1997 . . 49

Consumption and Costs of Federal Buildings Energy

by Fuel Type in FY 1997, FY 1995, and FY 1985 . . . . . . . . 50

Federal Buildings and Facilities Net Energy Use

Per Gross Square Foot, FY 1985 and FY 1997 . . . . . . . . . . . . . . . 53

Federal Buildings and Facilities Primary Energy Use

Per Gross Square Foot, FY 1985 and FY 1997 . . . . . . . . . . . . . 54

Federal Energy Consumption in Excluded Buildings/

Process Operations . . . . . . . . . . . . . . . . . . 61

Defense and Civilian Federal Costs for Excluded Buildings/

Process Energy in FY 1997 . . . . . . . . . . . . . . . . . .6 63

Federal Energy Consumption in Vehicle and Equipment Operations . . 67

Defense and Civilian Federal Costs for Vehicle and Equipment

Energy in FY 1997 
Table 11-B Consumption and Costs of Vehicle and Equipment Energy by Fuel Type in FY 1997, FY 1995, and FY 1985 ............ 70

Table 12 Federal Agency Progress Toward the Goals of Section 10 of Executive Order 12759, FY 1991 and FY 1997 ............. 72

Table 13 Federal Agency Consumption of Alternative Fuels in Non-Tactical Vehicles, FY 1997 . . . . . . . . . . . . . . . . . . . . . 75

Table C Federal Energy Expenditures, FY 1985 through FY 1997 . . . . . . . . C-2

\section{FIGURES}

Figure ES-1 Decrease in Btu per Gross Square Foot in Federal Buildings and Facilities from FY 1985 .................. 4

Figure ES-2 Federal Consumption of Petroleum-Based Fuels

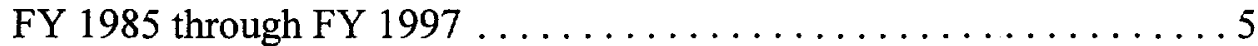

Figure $1 \quad$ Federal Energy Consumption, FY $1997 \ldots \ldots \ldots \ldots \ldots \ldots \ldots \ldots$

Figure $2 \quad$ Federal Energy Costs, FY $1997 \ldots \ldots \ldots \ldots \ldots \ldots \ldots \ldots \ldots$

Figure 3 Carbon Emissions from Federal Energy Consumption,

FY 1990 to FY 1997 ............................. 16

Figure $4 \quad$ Energy Conservation Retrofit Expenditures $\ldots \ldots \ldots \ldots \ldots \ldots \ldots 29$

Figure 5 Defense and Civilian Energy Consumption

in Buildings and Facilities by Fuel Type, FY 1997 . . . . . . . . . 43

Figure 6 Consumption of Electricity and Other Fuels

in Buildings and Facilities, FY 1985 through FY 1997 ......... 46

Figure 7 Energy Expenditures (Constant 1997 Dollars) in Buildings and Facilities, FY 1985 through FY 1997 .................. 47

Figure 8 Progress Toward the Energy Reduction Goals for Buildings and Facilities, FY 1985 through FY 1997 ........... 51

Figure 9 Range of Energy Intensity (Btu/GSF) in Buildings and Facilities by Agency in FY 1997 . . . . . . . . . . . . . . . . . . . . . . . 56

Figure 10 Defense and Civilian Federal Energy Consumption in Vehicles and Equipment by Fuel Type, FY 1997 . . . . . . . . . 68

\section{APPENDICES}

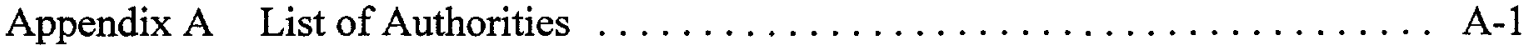

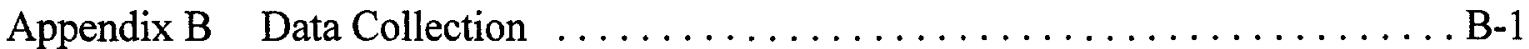

Appendix C Federal Energy Expenditures FY 1985 through FY 1997 . . . . . . . C-1

Appendix D Buildings Exempted From NECPA's Performance Goal in FY 1997 . D-1

Appendix E Department of Energy: Education, Extension, and Information Services ........................ E-1

Appendix F Federal Interagency Energy Policy Committee $\ldots \ldots \ldots \ldots \ldots \ldots$ F-1

Appendix G Personnel of the Department of Energy's Federal

Energy Management Program ..................... G-1 
AGENCY ACRONYMS

Commodity Futures Trading Commission

Central Intelligence Agency

CFTC

Department of Agriculture

CIA

Department of Commerce

USDA

Department of Defense

DOC

Department of Energy

DOD

Department of Health and Human Services

DOE

Department of Housing and Urban Development

Department of the Interior

HHS

HUD

Department of Justice

DOI

Department of Labor

DOJ

Department of State

DOL

ST

Department of Transportation

DOT

Department of the Treasury

Department of Veterans Affairs

TRSY

Environmental Protection Agency

VA

EPA

Equal Employment Opportunity Commission

EEOC

Federal Communications Commission

FCC

Federal Emergency Management Agency

FEMA

Federal Energy Regulatory Commission

FERC

Federal Trade Commission

FTC

General Services Administration

GSA

National Aeronautics and Space Administration

NASA

National Archives and Records Administration

NARA

National Science Foundation

NSF

Nuclear Regulatory Commission

NRC

Office of Personnel Management

OPM

Panama Canal Commission

PCC

Railroad Retirement Board

RRB

SSA

TVA

USIA

Tennessee Valley Authority

USPS

United States Postal Service

INTERNET WEB SITES CITED IN THIS REPORT

Federal Energy Management Program

Energy Efficiency and Renewable

Energy Clearinghouse

National Energy Information Center

Alternative Fuels Data Center

Clean Cities Program www.eren.doe.gov/femp

www.eren.doe.gov

www.eia.doe.gov

www.afdc.nrel.gov

www.ccities.doe.gov 


\section{EXECUTIVE SUMMARY}

This report on Federal Energy Management for Fiscal Year (FY) 1997 provides information on energy consumption in Federal buildings, operations, and vehicles and equipment, and documents activities conducted by Federal agencies to meet the statutory requirements of Title V, Part 3, of the National Energy Conservation Policy Act (NECPA), as amended, 42 U.S.C. $\S \S$ 8251-8259, 8262, 8262b-k, and Title VIII of NECPA, 42 U.S.C. $§ 8287-8287 \mathrm{c}$. Implementation activities undertaken during FY 1997 by the Federal agencies under the Energy Policy Act of 1992 (EPACT) and Executive Order 12902, Energy Efficiency and Water Conservation at Federal Facilities, are also discussed in this report.

Based on reports submitted to the Department of Energy (DOE) by 30 Federal agencies, the total primary energy consumption of the Government of the United States, including energy consumed to produce, process, and transport energy, was 1.53 quadrillion British Thermal Units (quads) during FY 1997. ${ }^{\text {Th }}$ These 1.53 quads consumed by the Government in buildings and operations to provide essential services to its citizens, including the defense of the Nation, represent approximately 1.6 percent of the total 94.21 quads $^{2}$ used in the United States. In total, the Federal Government is the single largest energy consumer in the Nation, although its pattern of consumption is widely dispersed.

The Government consumed 1.08 quads during FY 1997 when measured in terms of energy actually delivered to the point of use (net energy consumption). Unless otherwise noted, this report uses the site-measured conversion factors for electricity and steam. The total net energy consumption in FY 1997 decreased 25.1 percent from the FY 1985 base year. This reduction of 363.4 trillion Btu could satisfy the energy needs of the State of Idaho for more than one year. ${ }^{3}$

The total cost of the 1.08 quads was almost $\$ 8.3$ billion in FY $1997 .{ }^{4}$ This is $\$ 2.2$ billion less than the $\$ 10.5$ billion reported in FY 1985 , a 21.2 percent $^{5}$ decrease in nominal costs. In constant 1997 dollars, this equates to a decrease of 47.4 percent from $\$ 15.0$ billion in FY 1985 to $\$ 8.3$

${ }^{1}$ Primary energy consumption considers all resources used to generate and transport electricity and steam. Tables 1-A, 4-A, and 7-B show primary energy consumption for comparison with net consumption, Tables 1-B, 4-B, and 7-A respectively. Conversion factors of 11,600 Btu per kilowatt hour for electricity and 1,390 Btu per pound of steam are used to calculate gross energy consumption.

${ }^{2}$ DOE/EIA-0384(97), Annual Energy Review 1997, July 1998.

${ }^{3}$ Based on net energy consumption estimates for 1994 in the residential, commercial, industrial, and transportation sectors (299.8 trillion Btu). Source: DOE/EIA-0214(94), State Energy Data Report, 1994, Tables 4, 5, 6, and 7; October 1996.

${ }^{4}$ Unless otherwise noted, all costs cited in this report are in constant 1997 dollars, calculated using Gross Domestic Product implicit price deflators. See DOE/EIA-0384(97), Annual Energy Review 1997, Table 3.1; July 1998. Costs noted as nominal dollars reflect the price paid at the time of the transaction and have not been adjusted to remove the effect of changes in the spending power of the dollar.

${ }^{5}$ Calculation of percent changes in this report do not account for rounding of numbers in text. 
billion in FY 1997, which reflects the reduced energy use and a 25.8 percent reduction in the inflation-adjusted cost of energy per quad. The Federal energy bill for FY 1997 increased $\$ 400.6$ million from \$7.9 billion constant dollars spent in FY 1996.

Federal agencies report energy consumption under three categories: buildings and facilities, energy intensive operations, and vehicles and equipment.

\section{Buildings and Facilities}

In FY 1997, the Federal Government used 350.3 trillion British Thermal Units (Btu) to provide energy to approximately 500,000 buildings and facilities. This consumption represents a 25.7 percent decrease compared to FY 1985 and a 3.9 percent decrease relative to FY 1996. The cost of energy for buildings and facilities in FY 1997 was $\$ 3.6$ billion, a decrease of approximately $\$ 145.8$ million from FY 1996 expenditures, and a decrease of 37.8 percent from the FY 1985 expenditure of $\$ 5.7$ billion. ${ }^{6}$

During FY 1997, Federal agencies had three primary options for financing energy efficiency, water conservation, and renewable energy projects in buildings and facilities: direct appropriated funding, energy savings performance contracts (ESPCs), and utility-sponsored demand side management (DSM) incentives. Funding from the three sources totaled approximately $\$ 229.3$ million in FY 1997. Direct appropriations accounted for approximately $\$ 200.4$ million. ESPC contracts awarded in FY 1997 resulted in \$26.5 million in known contractor investment, and agencies reported more than $\$ 2.4$ million in utility incentives received. FY 1997 also saw the award of DOE's first regional indefinite-delivery, indefinite-quantity Super ESPC to six contractors. These contractors will provide a wide range of energy savings services to Federal facilities in the western region of the U.S. (Alaska, Arizona, California, Hawaii, Idaho, Nevada, Oregon, Washington and the U.S. Pacific Territories).

In FY 1997, direct appropriated funding identified by agencies for energy conservation retrofits and capital equipment increased 8.7 percent from $\$ 182.9$ million dollars in FY 1996 to $\$ 200.4$ million. However, this is still 33.3 percent less than the FY 1995 appropriations.

\section{Energy Intensive Operations}

The energy intensive operations category covers energy used in buildings excluded from the 10 and 20 percent reduction goals for buildings and facilities under section 543 of NECPA, 42 U.S.C. $\S \S 8253(\mathrm{a})(2)$ and 8253 (c). This category includes the energy consumed in industrial operations, certain research and development activities, and electronics-intensive facilities.

In FY 1997, the Federal Government used 66.5 trillion Btu of energy in energy intensive operations, approximately 6.1 percent of the total 1.08 quads consumed. Total energy consumption in this category increased 67.4 percent relative to FY 1985 and decreased 10.3

\footnotetext{
${ }^{6} \mathrm{Cost}$ and consumption figures for FY 1985 may be different from those published in last year's Annual Report since Federal agencies update their files and provide revisions to their data.
} 
percent relative to FY 1996. This increase is the result of changes in reporting procedures by individual agencies as well as changes in agency missions.

The Federal Government spent $\$ 662.2$ million on energy intensive operations energy in FY 1997 , $\$ 13.5$ million more than the FY 1996 expenditure of $\$ 648.7$ million constant dollars.

\section{Vehicles and Equipment}

The vehicles and equipment category includes aircraft and naval fuels, automotive gasoline, diesel fuel consumed by Federally-owned and leased vehicles and privately-owned vehicles used for official business, and the energy used in Federal construction.

In FY 1997, the Federal Government used approximately 665.4 trillion Btu of energy in vehicles and equipment, approximately 61.5 percent of the total 1.08 quads consumed. Total energy consumption in vehicles and equipment decreased 28.8 percent relative to FY 1985 and was 1.4 percent less than the FY 1996 consumption of 675.1 trillion Btu. The Department of Defense consumed 617.2 trillion Btu or 92.8 percent of all vehicles and equipment energy used by the Federal Government.

The Federal Government spent approximately $\$ 4.0$ billion on vehicles and equipment energy in FY 1997, \$532.8 million more than the FY 1996 expenditure.

\section{Agency Progress in Meeting Energy Reduction Goals}

NECPA, as amended by EPACT, requires agencies to take the steps necessary to reduce energy consumption in Federal buildings by 10 percent by 1995 compared to 1985 consumption levels, based on Btu per gross square foot, and requires a 20 percent reduction by 2000 compared to 1985 consumption levels. The 10 percent goal was met by the Government in FY 1995 with a 13.9 percent reduction from FY 1985. Executive Order 12902 adds an additional goal of reducing energy consumption by 30 percent by the year 2005 relative to 1985 consumption levels. During FY 1997 agencies provided data to DOE that indicated a decrease in energy consumption per gross square foot by 17.0 percent relative to FY 1985 . The Government's performance for each year since FY 1985 is illustrated in Figure ES-1. This reduction was the result of significant decreases in the consumption of fuel oil, natural gas, and coal. The use of non-electric fuels in Federal buildings has declined approximately 37.5 percent since 1985, while the consumption of electricity has increased by only 0.8 percent. The installation and increased use of electricity-driven electronic equipment contributed to increases in electricity, which peaked in FY 1990 at 11.2 percent above FY 1985. Since FY 1990, electricity consumption has declined 9.4 percent. Electricity now represents about 71.9 percent of the total energy costs of Federal buildings and accounts for 41.6 percent of total net energy consumption in buildings. This is compared to 30.7 percent of the total net energy consumption in buildings in FY 1985 . Agency efforts undertaken in FY 1997 to increase energy efficiency in buildings included:

- improvement of operations and maintenance procedures;

- implementation of no-cost, low-cost efficiency measures; 
FIGURE ES-1

Decrease in Btu per Gross Square Foot in Federal Buildings and Facilities from FY 1985

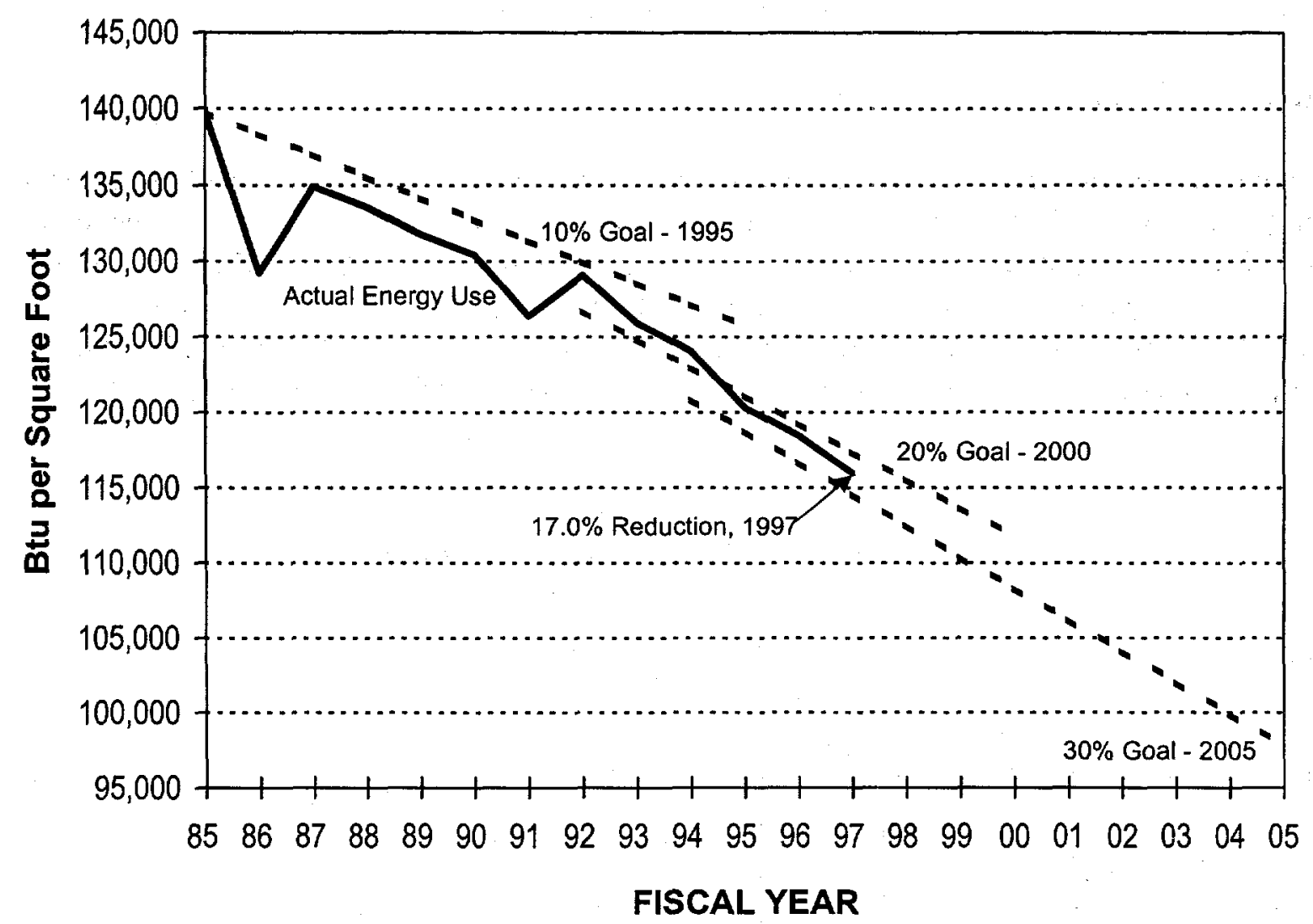

- energy-efficient building retrofits and capital improvements;

- energy awareness activities and employee training programs; and

- procurement of energy-efficient goods and products.

Executive Order 12902 expands the scope of Federal energy management activities beyond the NECPA mandates by establishing goals for industrial facilities. Section 301(b) of Executive Order 12902 requires agencies to implement programs in industrial facilities to increase energy efficiency by at least 20 percent in FY 2005 in comparison to FY 1990 consumption levels to the extent that measures undertaken to achieve the goal are cost-effective.

\section{Procurement of Energy-Efficient Products}

Section 507 of Executive Order 12902 requires all Federal agencies to buy "best practice" products when practicable, when they meet the agency's specific performance requirements, and are cost-effective. Best practice products are those which are in the upper 25 percent of energy efficiency for all similar products, or products that are at least 10 percent more efficient than the minimum level that meets Federal standards. During FY 1997, DOE continued its program to assist agencies in implementing the EPACT and Executive Order requirements for energy 
efficient procurement. In 1997, DOE's Federal Energy Management Program (FEMP) produced and distributed eight additional product energy efficiency recommendations to be added to the one-stop shopping guide, Buying Energy Efficient Products, to help Federal purchasers identify products which meet the energy efficiency requirements of Executive Order 12902. The guide now includes 22 product energy efficiency recommendations.

\section{Reducing Petroleum-Based Fuel Consumption}

Effective management of energy resources is of strategic importance to the Federal Government as well as the Nation. In FY 1997, petroleum-based fuels accounted for 0.71 quads of the total 1.08 quads consumed by the Federal Government, with 0.66 quads used by the Department of Defense primarily for jet fuel and distillate/diesel for vehicles and equipment. The Federal Government consumed 31.5 percent less petroleum-based fuel in FY 1997 than in FY 1985. Figure ES-2 illustrates the trend in the Federal Government's use of petroleum fuels.

FIGURE ES-2

Federal Consumption of Petroleum-Based Fuels

FY 1985 through FY 1997

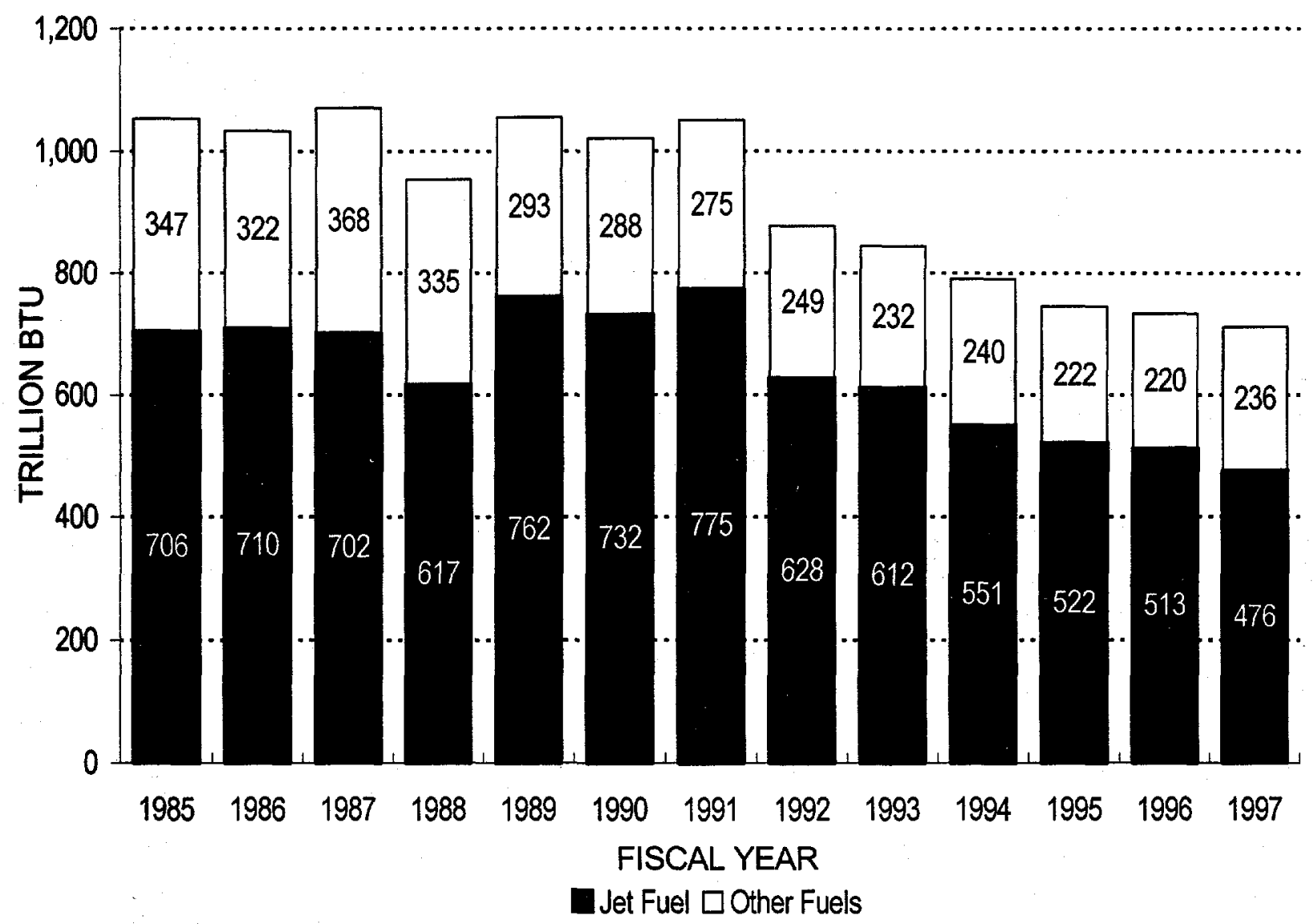


Due to the strategic nature of petroleum-based fuels, section 305 of Executive Order 12902 directs agencies to minimize the use of petroleum-based fuels in buildings and facilities. Federal agencies have made significant progress in reducing their dependence on petroleum-based fuels in their buildings and facilities. For example, Federal agencies report that in FY 1997, 42.0 trillion Btu of petroleum-based fuels were used for buildings and facilities energy, a 62.2 percent decrease from FY 1985 and a 19.3 percent decrease from FY 1996. This represents 12.0 percent of total buildings and facilities energy consumption.

\section{Federal Energy Management Highlights}

Progress is being made in increasing Federal energy efficiency, although there remain opportunities for greater efficiency and cost reduction. Several of the most important findings of this report are listed below:

- The overall real cost of energy consumption in the Federal Government has fallen from $\$ 15.0$ billion in FY 1985 to \$8.3 billion in FY 1997.

- Total net energy consumption in FY 1997 decreased 25.1 percent from FY 1985.

- Energy consumption in buildings in FY 1997 decreased 25.7 percent from FY 1985.

- On a Btu-per-gross-square-foot basis, the 17.0 percent reduction in buildings energy puts the Federal Government on track to meet the 20 percent reduction goal for 2000 .

- Six agencies, the Departments of Agriculture, Commerce, Energy, and Justice, the Federal Emergency Management Agency, and the National Aeronautics and Space Administration have surpassed a 20 percent reduction in buildings energy use per gross square foot from 1985.

- Energy consumption in FY 1997 was used for the following purposes:

End Use

Buildings \& Facilities

Energy Intensive Operations

Vehicles \& Equipment
Percentage

32.4 percent

6.1 percent

61.5 percent
Cost

$\$ 3.6$ billion

$\$ 0.7$ billion

$\$ 4.0$ billion 


\section{OVERVIEW OF FEDERAL ENERGY MANAGEMENT ACTIVITIES}

\section{A. Overview of Federal Energy Management Policy and Legislative Mandates}

This report on Federal Energy Management for Fiscal Year (FY) 1997 provides information on energy consumption in Federal buildings and operations and documents activities conducted by Federal agencies to meet the statutory requirements of Title V, Part 3, of the National Energy Conservation Policy Act (NECPA), as amended, 42 U.S.C. $\S \S 8251-8259,8262,8262 \mathrm{~b}-\mathrm{k}$ and Title VIII of NECPA, 42 U.S.C. § 8287-8287c. Implementation activities undertaken during FY 1997 by the Federal agencies under the Energy Policy Act of 1992 (EPACT), Executive Order 12759 on Federal Energy Management, and Executive Order 12902, Energy Efficiency and Water Conservation at Federal Facilities, are also described in this report. In compliance with section 381(c) of the Energy Policy and Conservation Act (EPCA), as amended, 42 U.S.C. § $6361 \mathrm{c}$, this report also describes the energy conservation and management activities of the Federal Government under the authorization of section 381 of EPCA, 42 U.S.C. $\$ 6361$.

\section{Requirements of National Energy Conservation Policy Act (NECPA) and Energy Policy Act of 1992 (EPACT)}

NECPA provides major policy guidance to Federal agencies to improve energy management in their facilities and operations. Amendments to NECPA made by the Federal Energy Management Improvement Act of 1988, 42 U.S.C. $\S 8253$ (a)(1), required each agency to achieve a 10 percent reduction in energy consumption in its Federal buildings by FY 1995, when measured against a FY 1985 baseline on a Btu-per-gross-square-foot basis. It also directed DOE to establish life-cycle costing methods and coordinate Federal conservation activities through the Interagency Energy Management Task Force. Section 152 of Subtitle F of EPACT, Federal Agency Energy Management, further amends NECPA and contains provisions regarding energy management requirements, life-cycle cost methods and procedures, budget treatment for energy conservation measures, incentives for Federal facility energy managers, reporting requirements, new technology demonstrations, and agency surveys of energy-saving potential.

\section{Requirements of Executive Orders 12759 and 12902}

During FY 1997, two Executive Orders pertaining to energy management were in effect for Federal agencies. Executive Order 12759 on Federal Energy Management, signed by President Bush in April 1991, expanded the scope of Federal energy management activities beyond the NECPA requirements to include industrial facilities and Federal vehicles. Executive Order 12902, Energy Efficiency and Water Conservation at Federal Facilities, signed by President Clinton on March 8, 1994, supersedes Executive Order 12759 but leaves in effect sections 3, 9, and 10 of that Order.

The key requirements of the legislation and Executive Order authorities are outlined in the exhibit below along with current findings. 


\section{KEY REQUIREMENTS OF LEGISLATIVE AND EXECUTIVE ORDER AUTHORITIES}

\begin{tabular}{|c|c|c|c|}
\hline Statute/Directive & Requirement & FY 1997 Findings & $\begin{array}{l}\text { Annual Report } \\
\text { Discussion }\end{array}$ \\
\hline $\begin{array}{l}\text { Section } 543, \text { NECPA, } \\
42 \text { U.S.C., } § 8253(a)(1) \\
\text { Executive Order } 12902\end{array}$ & $\begin{array}{l}20 \text { percent reduction (Btu/GSF) } \\
\text { by } 2000 \text { from } 1985 \\
30 \text { percent reduction (Btu/GSF) } \\
\text { in Federal buildings by } 2005 \\
\text { from } 1985\end{array}$ & $\begin{array}{l}\text { Federal agencies reported a } \\
17.0 \text { percent decrease in } \\
\text { energy consumption in } \\
\text { buildings in FY } 1997, \\
\text { compared to FY } 1985\end{array}$ & $\begin{array}{l}\text { Section II (B), } \\
\text { page } 51\end{array}$ \\
\hline $\begin{array}{l}\text { Section 545, NECPA, } \\
42 \text { U.S.C., } \$ 8254\end{array}$ & $\begin{array}{l}\text { DOE to establish life-cycle cost } \\
\text { methods to determine cost- } \\
\text { effectiveness of proposed energy } \\
\text { efficiency projects }\end{array}$ & $\begin{array}{l}\text { The } 1997 \text { edition of the } \\
\text { energy price indices and } \\
\text { discount factors for life- } \\
\text { cycle cost analysis was } \\
\text { published and distributed to } \\
\text { Federal energy managers }\end{array}$ & $\begin{array}{l}\text { Section } I(F) \text {, } \\
\text { page } 36\end{array}$ \\
\hline $\begin{array}{l}\text { Section } 545, \text { NECPA, } \\
42 \text { U.S.C., } \S 8255\end{array}$ & $\begin{array}{l}\text { Transmit to Congress the amount } \\
\text { of appropriations requested in } \\
\text { each agency budget for electric } \\
\text { and energy costs incurred in } \\
\text { operating and maintaining } \\
\text { facilities and for compliance with } \\
\text { applicable statutes and directives }\end{array}$ & $\begin{array}{l}\text { Approximately } \$ 200.4 \\
\text { million was appropriated } \\
\text { and spent on energy } \\
\text { efficiency projects in } \\
\text { Federal facilities }\end{array}$ & $\begin{array}{l}\text { Section } I(E), \\
\text { page } 27\end{array}$ \\
\hline $\begin{array}{l}\text { Section 546, NECPA, } \\
42 \text { U.S.C., } \$ 8256(\text { a) }\end{array}$ & $\begin{array}{l}\text { Establishment of a program of } \\
\text { incentives within Federal } \\
\text { agencies to expedite Energy } \\
\text { Savings Performance Contracts }\end{array}$ & $\begin{array}{l}21 \text { ESPC contracts were } \\
\text { awarded by Federal } \\
\text { agencies }\end{array}$ & $\begin{array}{l}\text { Section } I(E) \text {, } \\
\text { page } 32\end{array}$ \\
\hline $\begin{array}{l}\text { Section 546, NECPA, } \\
42 \text { U.S.C., } \S 8256(\mathrm{~b})\end{array}$ & $\begin{array}{l}\text { DOE to establish a Federal } \\
\text { Energy Efficiency Fund to } \\
\text { provide grants to agencies }\end{array}$ & $\begin{array}{l}\text { There were no appropri- } \\
\text { ations for the Fund in FY } \\
\text { 1997; FY } 1995 \text { funds were } \\
\text { allocated and progress of } \\
\text { the few remaining projects } \\
\text { is being monitored }\end{array}$ & $\begin{array}{l}\text { Section I }(E), \\
\text { page } 29\end{array}$ \\
\hline $\begin{array}{l}\text { Section 157, EPACT, } \\
42 \text { U.S.C., } \S 8262(\mathrm{c})\end{array}$ & $\begin{array}{l}\text { Federal agencies to establish and } \\
\text { maintain programs to train energy } \\
\text { managers and to increase the } \\
\text { number of trained energy } \\
\text { managers within each agency }\end{array}$ & $\begin{array}{l}\text { DOE's FEMP conducted } 55 \\
\text { training workshops and } \\
\text { symposia for more than } \\
1,700 \text { attendees in the } \\
\text { efficient use and } \\
\text { conservation of energy, } \\
\text { water, and renewable } \\
\text { energy in Federal facilities. }\end{array}$ & $\begin{array}{l}\text { Section I }(D), \\
\text { page } 19 ; \\
\text { Section V, Agency } \\
\text { Reports }\end{array}$ \\
\hline Executive Order 12902 & $\begin{array}{l}20 \text { percent reduction (Btu/GSF) } \\
\text { for Federal industrial facilities by } \\
2005 \text { from } 1990\end{array}$ & $\begin{array}{l}\text { Findings are specific to } \\
\text { individual agencies }\end{array}$ & $\begin{array}{l}\text { Section III (A), } \\
\text { page } 62\end{array}$ \\
\hline Executive Order 12902 & $\begin{array}{l}\text { Conduct prioritization surveys to } \\
\text { establish facility audit priorities. } \\
\text { Implement } 10 \text {-year plan to } \\
\text { conduct comprehensive audits. }\end{array}$ & $\begin{array}{l}\text { Findings are specific to } \\
\text { individual agencies }\end{array}$ & $\begin{array}{l}\text { Section V, Agency } \\
\text { Reports }\end{array}$ \\
\hline
\end{tabular}




\begin{tabular}{|c|c|c|c|}
\hline Statute/Directive & Requirement & FY 1997 Findings & $\begin{array}{l}\text { Annual Report } \\
\text { Discussion }\end{array}$ \\
\hline $\begin{array}{l}\text { Executive Order } 12759 \\
\text { Executive Order } 12902\end{array}$ & $\begin{array}{l}\text { Minimize the use of petroleum } \\
\text { products for facilities operations } \\
\text { or building purposes through } \\
\text { switching to an alternative energy } \\
\text { source if it is estimated to } \\
\text { minimize life-cycle costs; } \\
\text { improve the efficiency with } \\
\text { which petroleum is used in } \\
\text { facilities where alternative fuels } \\
\text { are not practical or cost-effective }\end{array}$ & $\begin{array}{l}\text { The consumption of } \\
\text { petroleum-based fuels in } \\
\text { buildings during FY } 1997 \\
\text { decreased } 62.2 \text { percent } \\
\text { compared to FY } 1985 \text { and } \\
19.4 \text { percent from FY } 1996\end{array}$ & $\begin{array}{l}\text { Section II }(A) \text {, } \\
\text { page } 47\end{array}$ \\
\hline Executive Order 12902 & $\begin{array}{l}\text { Agencies should strive to } \\
\text { purchase products in the top } 25 \\
\text { percent of their class for energy } \\
\text { efficiency }\end{array}$ & $\begin{array}{l}\text { A Federal Acquisition } \\
\text { Circular was issued. Eight } \\
\text { new product energy } \\
\text { efficiency recommendations } \\
\text { were issued by DOE, } \\
\text { bringing the total to } 22 \text {. }\end{array}$ & $\begin{array}{l}\text { Section I }(G) \text {, } \\
\text { page } 36\end{array}$ \\
\hline Executive Order 12902 & $\begin{array}{l}\text { Agencies to ensure design and } \\
\text { construction of new buildings } \\
\text { meet or exceed whichever energy } \\
\text { performance standards will result } \\
\text { in a lower life-cycle cost over the } \\
\text { life of the building. Also } \\
\text { contains provisions for agencies } \\
\text { to showcase their best efficiency } \\
\text { and renewable energy projects }\end{array}$ & $\begin{array}{l}\text { The Energy Code for New } \\
\text { Federal Commercial and } \\
\text { Multi-Family High Rise } \\
\text { Residential Buildings } \\
\text { revises the interim Federal } \\
\text { standards to conform } \\
\text { generally with the codified } \\
\text { version of ASHRAE } \\
\text { Standard } 90.1-1989 . \\
\text { Twenty-seven Federal } \\
\text { Energy Saver Showcases } \\
\text { were designated. }\end{array}$ & $\begin{array}{l}\text { Section II (D), } \\
\text { page } 58 \\
\text { Section I }(D) \text {, } \\
\text { page } 25\end{array}$ \\
\hline
\end{tabular}




\section{B. Overall Federal Energy Consumption, Costs, and Carbon Emissions}

As shown in Table 1-A, the total primary energy consumption of the Government of the United States, including energy consumed to produce, process, and transport energy, was 1.53 quadrillion British Thermal Units (quads) or 1,527,136.5 billion Btu during FY 1997. Primary energy consumption considers all resources used to generate and transport electricity and steam. (The source conversion factors of 11,600 Btu per kilowatt hour for electricity and 1,390 Btu per pound of steam are used to calculate primary energy consumption. See Appendix B for conversion factors used to calculate net energy consumption.) These 1.53 quads represent approximately 1.6 percent of the total 94.21 quads $^{7}$ used in the United States, and reflect Government energy consumption in buildings and operations to provide essential services to its citizens, including the defense of the Nation. In total, the Federal Government is the single largest energy consumer in the Nation, although its pattern of consumption is widely dispersed.

Based on reports submitted to DOE by 30 Federal agencies, the Government consumed 1.08 quads during FY 1997 when measured in terms of energy actually delivered to the point of use (net consumption). As shown in Table 1-B, Federal agencies reported a 25.1 percent decrease in total net energy consumption compared to FY 1985, and a 2.3 percent decrease from FY 1996. The cost of this energy was $\$ 8.3$ billion and represented approximately 0.5 percent of the total Federal expenditures of $\$ 1.686$ trillion $^{8}$ for all purposes in FY 1997. The Federal energy bill for FY 1997 was approximately $\$ 400.6$ million more than the $\$ 7.9$ billion reported for FY $1996 .{ }^{9}$

In FY 1997, the Department of Defense spent $\$ 6.1$ billion for energy of the total Federal energy expenditure of $\$ 8.3$ billion. Overall, the Department of Defense used 29.6 percent less net energy in FY 1997 than in FY 1985.

Figures 1 and 2 depict the percentage of total energy used by the Federal Government in FY 1997 and its cost. As illustrated, jet fuel and electricity account for approximately 60.9 percent of the total energy consumption represented in Figure 1 and approximately 72.4 percent of the total energy costs in Figure 2.

Petroleum-based fuels used by the Federal Government are shown in Table 2. In FY 1997, petroleum-based fuels accounted for 0.71 quads ( $711,516.6$ billion Btu) of the total 1.08 quads consumed by the Federal Government. Of that, approximately 0.66 quads $(655,317.4$ billion Btu) were used by the Department of Defense primarily for jet fuel and distillate/diesel for vehicles and equipment energy. Only 0.04 quads (42,007.9 billion Btu) of petroleum-based fuels were used for Federal buildings and facilities energy.

\footnotetext{
${ }^{7}$ DOE/EIA-0384(97), Annual Energy Review 1997, July 1998.

${ }^{8}$ Analytical Perspectives, Budget of the United States Government, Fiscal Year 1998.

${ }^{9}$ Appendix $\mathrm{C}$ indicates the annual cost of energy used in Federal buildings and facilities, vehicles and equipment, and energy intensive operations for FY 1985 through FY 1997. The combined cost per Btu for energy in each fiscal year is also shown in the table.
} 
TABLE 1-A

TOTAL PRIMARY ENERGY CONSUMPTION BY FEDERAL AGENCIES

(In Billions of Btu, with Conversions to Millions of Barrels of Oil Equivalent [MBOE], and Petajoules [Joule x 10 ${ }^{15}$ ])

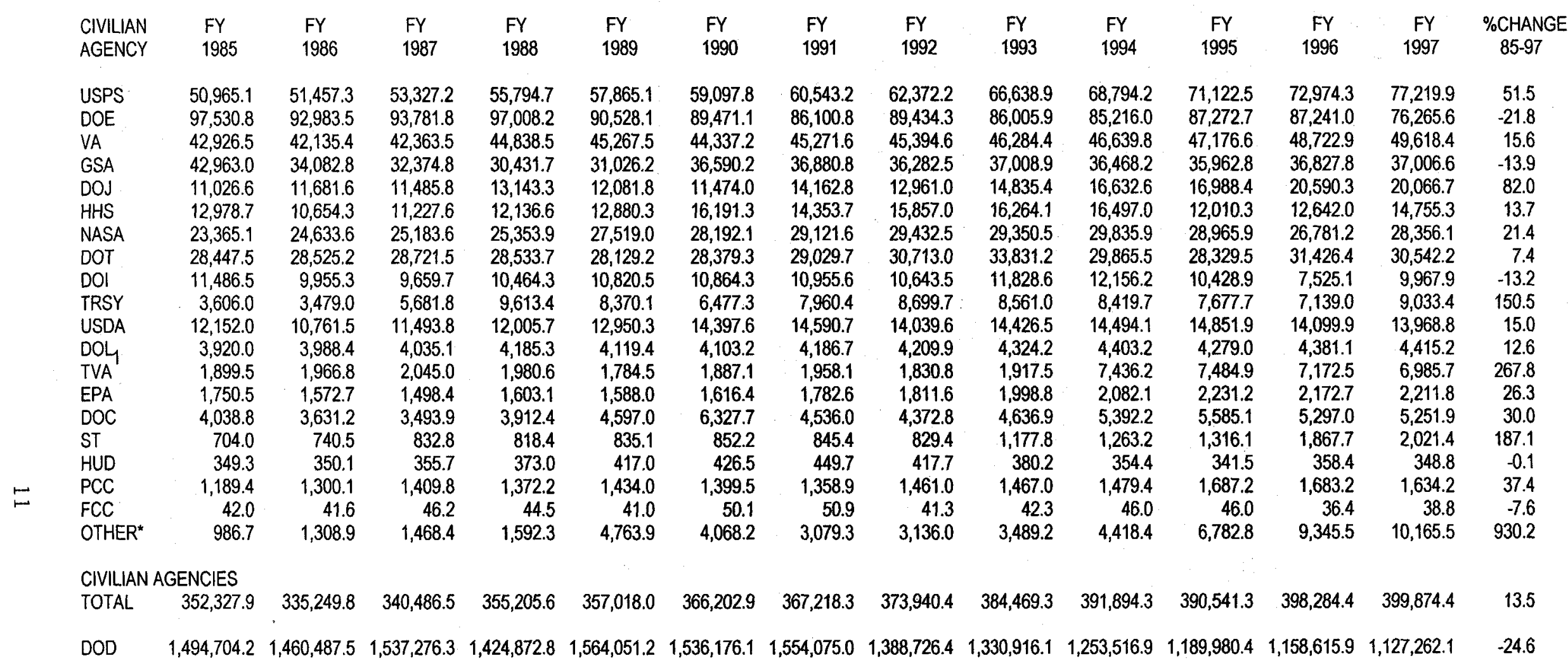

ALL AGENCIES

$\begin{array}{llllllllllllll}\text { TOTAL } & 1,847,032.2 & 1,795,737.3 & 1,877,762.8 & 1,780,078.3 & 1,921,069.1 & 1,902,379.0 & 1,921,293.3 & 1,762,666.8 & 1,715,385.4 & 1,645,411.3 & 1,580,521.6 & 1,556,900.2 & 1,527,136.5\end{array}$

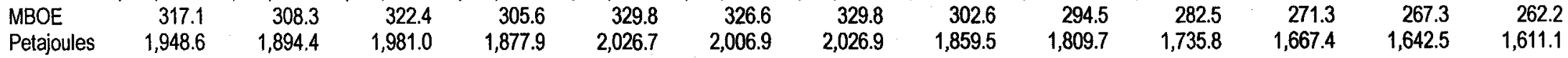

DATA AS OF 01/29/99

*Other includes, for certain years, CFTC, CIA, EEOC, FEMA, FTC, NARA, NSF, NRC, OPM, RRB, SSA, USIA, and FERC.

1 TVA's increase in energy consumption beginning in FY 1994 is the result of first-time reporting of energy consumed at generation sites.

Note: This table uses a conversion factor for electricity of 11,600 Btu per kilowatt hour and 1,390 Btu per pound of steam. Agencies are listed in descending order of consumption for the current year. Sum of components may not equal total due to independent rounding.

Source: Federal Agency Annual Energy Management Data Reports 
TABLE 1-B

TOTAL NET ENERGY CONSUMPTION BY FEDERAL AGENCIES

(In Billions of Btu, with Conversions to Millions of Barrels of Oil Equivalent [MBOE], and Petajoules [Joule x $\left.10^{15}\right]$ )

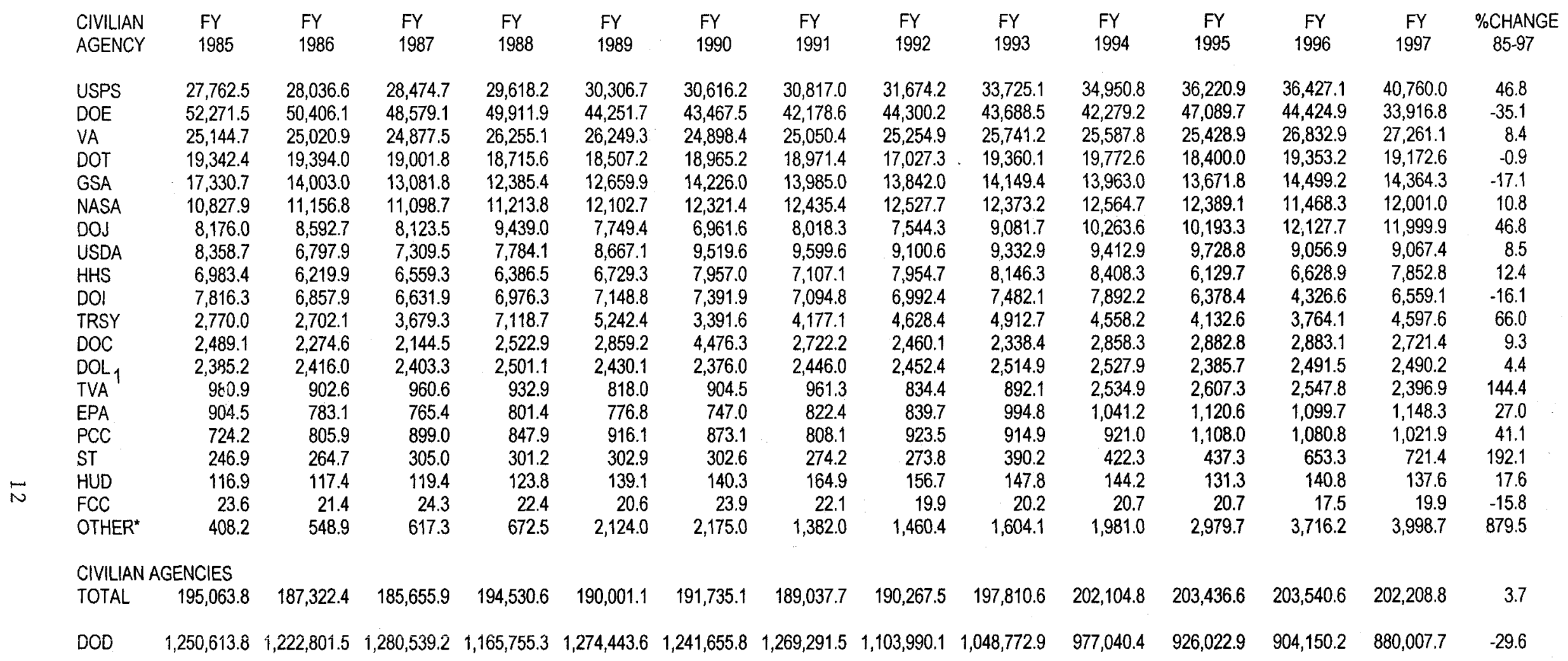

ALL AGENCIES

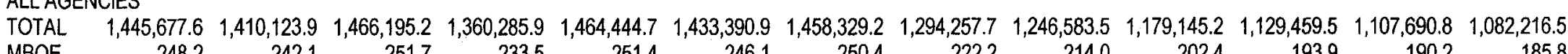

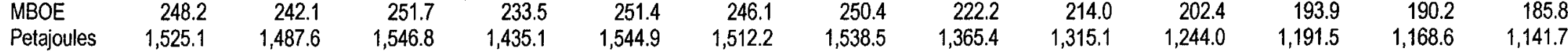

DATA AS OF 01/29/99

*Other includes, for certain years, CFTC, CIA, EEOC, FEMA, FTC, NARA, NSF, NRC, OPM, RRB, SSA, USIA, and FERC

'TVA's increase in energy consumption beginning in FY 1994 is the result of first-time reporting of energy consumed at generation sites.

Note: This table uses a conversion factor for electricity of 3,412 Btu per kilowatt hour and 1,000 Btu per pound of steam. Agencies are listed in descending order of consumption for the current year. Sum of components may not equal total due to independent rounding.

Source: Federal Agency Annual Energy Management Data Reports 

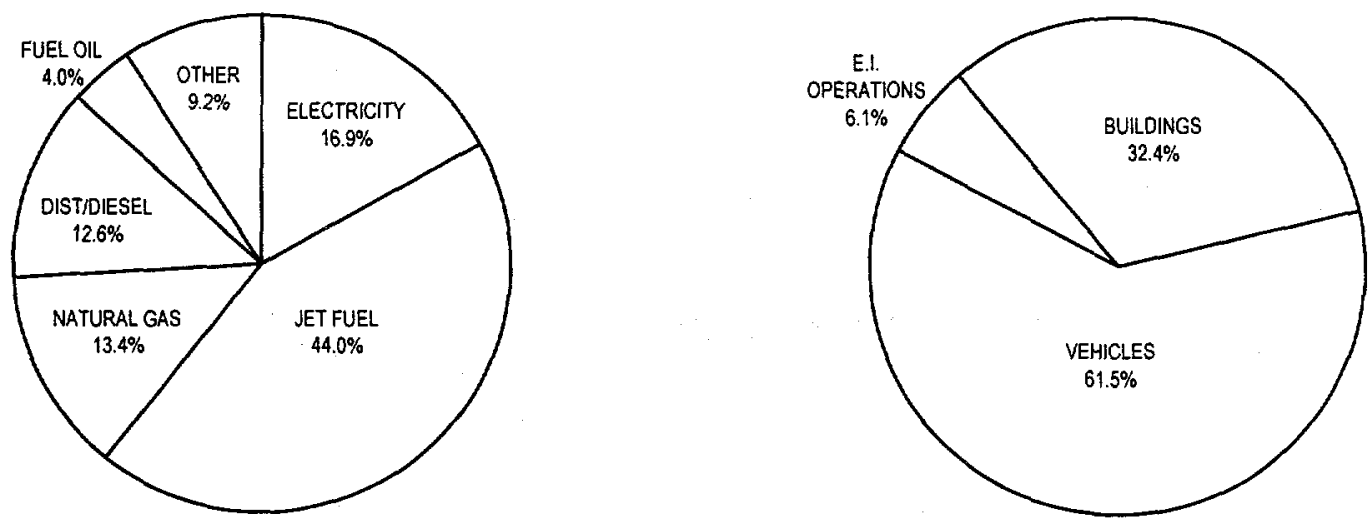

Buildings \& Facilities: 0.35 quads

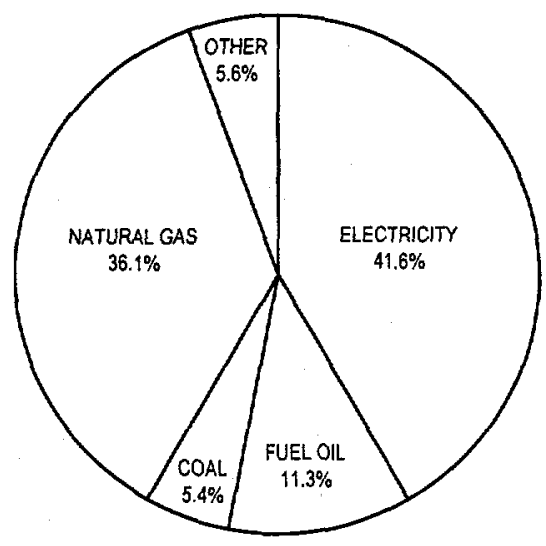

Energy Intensive Operations: 0.07 quads

Vehicles \& Equipment: 0.66 quads
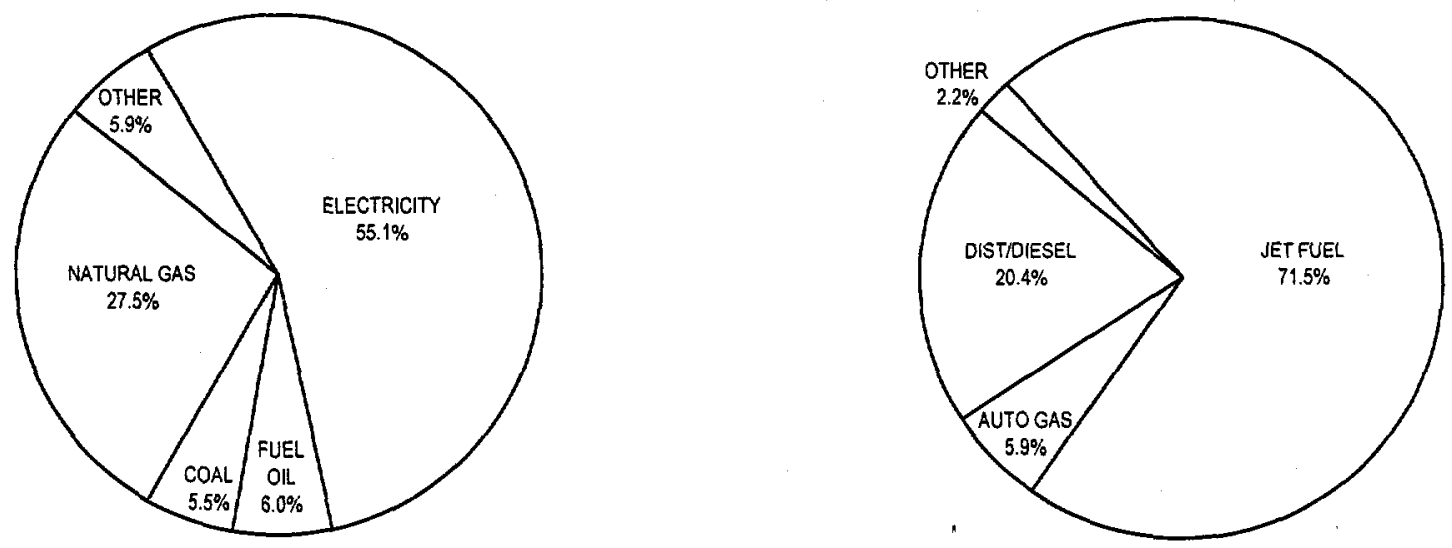

Data as of 01/29/99

Source: Federal Agency Annual Energy Management Data Reports

Note: Sum of components may not equal 100 percent due to independent rounding. 
FIGURE 2

Federal Energy Costs, FY 1997

Total by Energy Type: $\$ 8.25$ Billion

Total by Sector: $\$ 8.25$ Billion
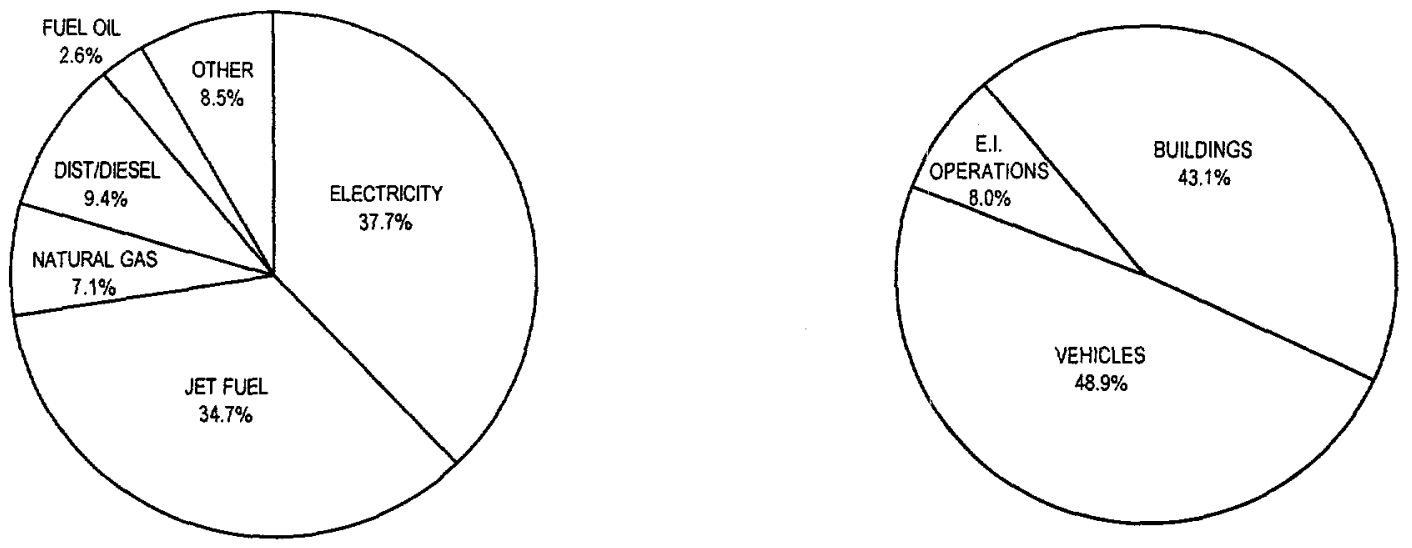

Buildings \& Facilities: \$3.56 Billion

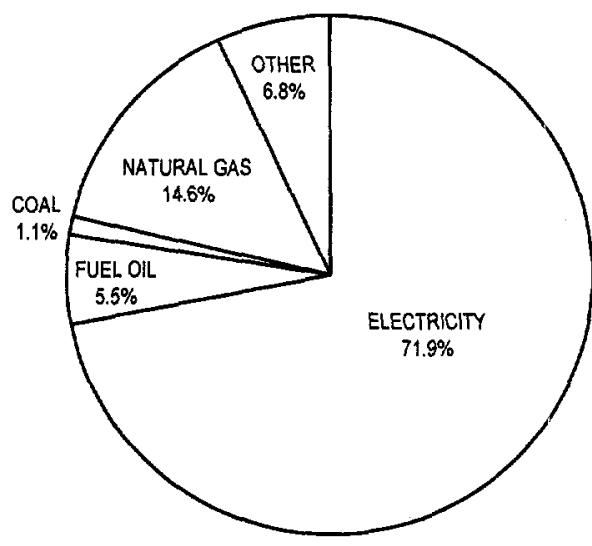

Energy Intensive Operations: \$0.66 Billion

Vehicles \& Equipment: \$4.03 Billion
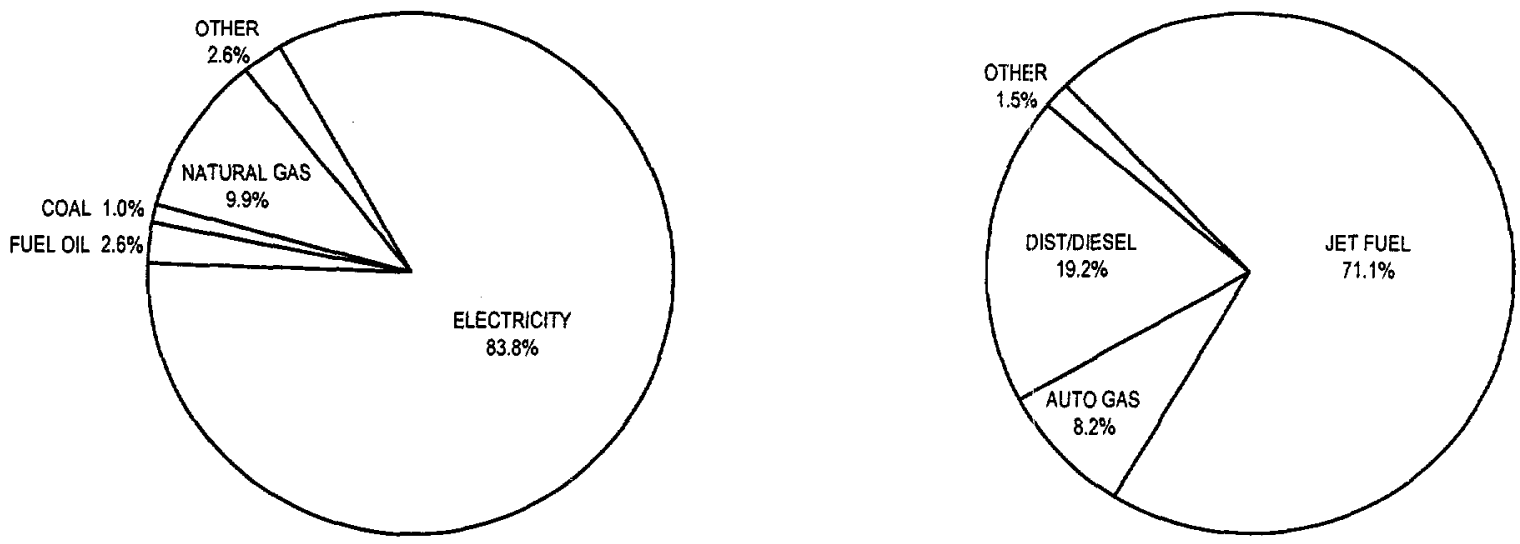

Data as of 01/29/99

Source: Federal Agency Annual Energy Management Data Reports

Note: Sum of components may not equal 100 percent due to independent rounding. 
TABLE 2

FEDERAL PETROLEUM USAGE IN FY 1997

(in Thousands of Gallons, Billions of Btu, and Petajoules [Joule x $10^{15}$ ])

$\begin{array}{rrrrr}\begin{array}{c}\text { Unit Total } \\ \text { (KGal) }\end{array} & \begin{array}{r}\text { BBTU* } \\ \text { DOD }\end{array} & \begin{array}{r}\text { BBTU* } \\ \text { Civilian }\end{array} & \begin{array}{c}\text { BBTU* } \\ \text { Total }\end{array} & \begin{array}{c}\text { Petajoules* } \\ \text { Total }\end{array} \\ & & & & \\ & & & & \\ 255,483.3 & 33,592.6 & 6,003.9 & 39,596.5 & 41.77 \\ & 1,621.8 & 789.6 & 2,411.4 & 2.54 \\ 28,597.1 & & & & \\ 1,837.0 & 2,744.9 & 1,221.5 & 3,966.4 & 4.18 \\ & 122.7 & 52.7 & 175.4 & 0.19 \\ 12,379.9 & & & & \\ 779,423.1 & & & & \\ 2,029.3 & 13,503.3 & 25,544.2 & 39,047.5 & 41.19 \\ 19,371.8 & 10,474.2 & 135,846.0 & 143.34 \\ 0.0 & 0.0 & 253.7 & 253.7 & 0.27 \\ 14,547.2 & 466,161.4 & 9,511.1 & 475,672.5 & 501.82 \\ & 0.0 & 0.0 & 0.0 & 0.00 \\ & 0.0 & 18.7 & 18.7 & 0.02 \\ & 12,199.0 & 2,348.2 & 14,547.2 & 15.35 \\ & & & & \\ & 655,317.4 & 56,199.3 & 711,516.6 & 750.60\end{array}$

Buildings \& Facilities

Fuel Oil

LPG/Propane

$285,483.3$

Energy Intensive Operations

Fuel Oil

LPG/Propane

$28,597.1$
$1,837.0$

$312,379.9$
$979,423.1$
$2,029.3$
$3,659,019.4$
0.0
196.1
$14,547.2$

Vehicles \& Equipment

Motor Gas

Dist. Diesel

Aviation Gas

Jet Fuel

Navy Special

LPG/Propane

Other

-

Total

$655,317.4$

$56,199.3$

DATA AS OF 01/29/99

*Uses a conversion factor of:

95,500 Btu/gallon for LPG/propane

$138,700 \mathrm{Btu} / \mathrm{gallon}$ for fuel oil, distillate-diesel \& petroleum, and navy special

$125,000 \mathrm{Btu} / \mathrm{gallon}$ for motor gasoline and aviation gasoline

$130,000 \mathrm{Btu} / \mathrm{gallon}$ for jet fuel

947.9 Billion Btu/Petajoule

Note: FY 1997 contains estimated data for the following agencies: FEMA, FTC, and OPM. Sum of components may not equal total due to independent rounding.

Source: Federal Agency Annual Energy Management Data Reports 
Carbon emissions from Federal energy consumption have decreased significantly since FY 1990, the base year for the Kyoto Protocol to the United Nations Framework on Climate Change. As shown in Figure 3, the Federal Government has reduced carbon emissions across the three enduse sectors by 21.8 percent from 33.9 million metric tons in FY 1990 to 26.5 million metric tons in FY 1997. ${ }^{10}$ The largest contribution to this reduction is from the vehicles and equipment sector, which has seen a decrease in carbon emissions of 27.9 percent. This is a result of a reduction of almost 5.1 million metric tons of carbon emissions from jet fuel as well as smaller reductions from diesel, aviation gasoline, navy special, and LPG/propane.

Carbon emissions have decreased by 16.9 percent in the buildings and facilities sector since 1990. Contributing to this reduction was a 10.7 percent reduction in gross square footage since FY 1990 and a 5.1 percent decrease in primary energy intensity (246,346 Btu/GSF in FY 1990, 233,896 Btu/GSF in FY 1997).

Carbon emissions from energy intensive activities in excluded buildings increased 2.8 percent $(63,473.1$ metric tons) since FY 1990.

FIGURE 3

\section{Carbon Emissions from Federal Energy Consumption, FY 1990 to FY 1997}

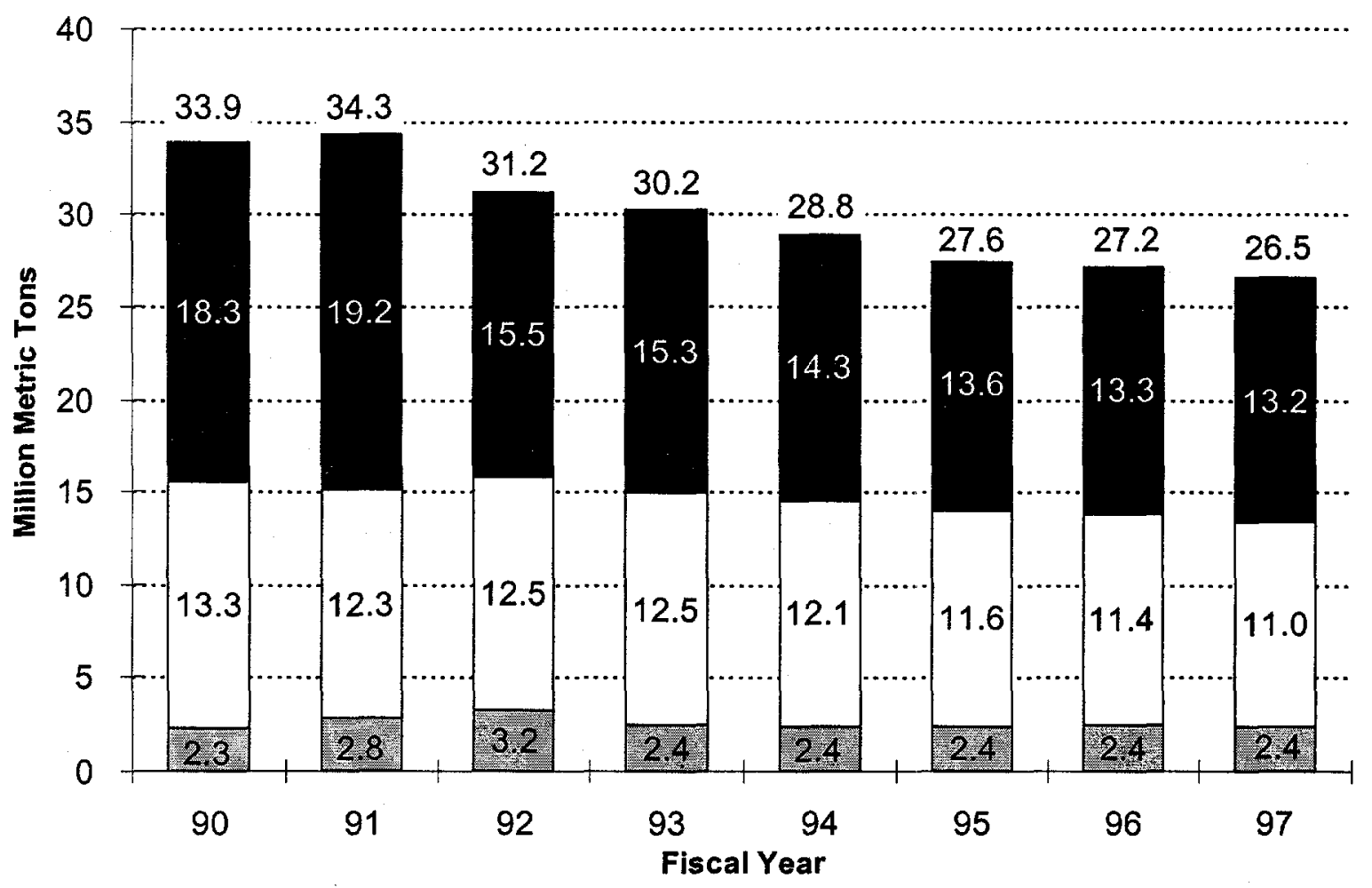

Excluded Bldgs \& Industrial $\square$ Buildings \& Facilities

Vehicles \& Equipment

\footnotetext{
${ }^{10} \mathrm{Carbon}$ emissions were calculated by multiplying energy consumption for each fuel type by an associated carbon coefficient shown in Appendix B. These coefficients are derived from DOE/EIA-0573, Emissions of Greenhouse Gases in the United States, 1987 - 1992, November 1994; Tables 5, A1, A3, and A4).
} 


\section{Federal Coordination}

\section{Federal Interagency Energy Policy Committee (“656” Committee)}

The Federal Interagency Energy Policy Committee ("656" Committee) was established in accordance with Section 656 of the Department of Energy Organization Act (P.L. 95-91) to strengthen Government programs that emphasize productivity through the efficient use of energy, and concurrently, to encourage interagency cooperation in energy conservation. In mid FY 1997, the resignation of Christine Ervin, Assistant Secretary for Energy Efficiency and Renewable Energy and Chair for the "656" Committee, in combination with a number of other vacancies in "656" Committee members, led to the postponement of the meeting scheduled for May 14, 1997. Although the "656" Committee did not meet in FY 1997, the Federal Interagency Energy Management Task Force coordinated a number of Federal energy management activities in FY 1997.

\section{Federal Interagency Energy Management Task Force}

The Interagency Energy Management Task Force was established by section 547 of NECPA, as amended, 42 U.S.C. $\$ 8257$. During the five meetings of the Task Force during FY 1997 the following subjects were examined and discussed:

October 24, 1996:

- FEMP's five-year energy awareness program, You Have the Power, was unveiled;

- The Task Force's Water Working Group addressed activities undertaken to reduce barriers to the implementation of water-savings projects;

- The Corporation for Solar Technologies and Renewable Resources, a nonprofit organization in Nevada, outlined developments toward reaching its goal of marketing 270 megawatts of electricity generated from photovoltaics; and

- Both the Renewable Energy Working Group and the Federal Procurement Working Group reported on their activities and progress.

February 13, 1997:

- The first guidance statement by the Alternative Financing Policy Subcommittee covering the authority to sole-source utility service contracts was discussed;

- A presentation was given on FEMP's Super Energy Savings Performance Contract vehicle designed to streamline the procurement process;

- The New Space Working Group reported that the Building Commissioning Guide was undergoing review and that a model commissioning plan will be developed; 
- Changes to the nomination criteria for the Federal Energy and Water Management Awards were outlined with copies distributed to the Task Force;

- An update on the New Technologies Demonstration Program was presented; and The signing of the Federal Green Lights and Energy Star Buildings Memorandum of Understanding by the Environmental Protection Agency and DOE was announced.

April 30, 1997:

- It was announced that the TeleFEMP V broadcast on Super Energy Savings Performance Contracts on May 22 would include a pretaped opening address by Secretary Peña;

- Issues related to utility rates in a deregulated environment were discussed;

- A representative from the National Fenestration Rating Council delivered a presentation on window standards and their window certification and labeling program;

- Updates were presented on the FY 1997 Federal Energy Saver Showcases and the Federal Procurement Challenge; and

- A new course on design of energy-efficient laboratories, developed by the EPA in collaboration with DOE's Lawrence Berkeley National Laboratory, was announced.

July 15, 1997:

- The findings of the Alternative Energy Financing Policy Subcommittee on Congressional notification for utility projects were summarized and a draft of the policy memorandum on this topic was distributed to Task Force members for comment;

- A representative of the General Services Administration briefed the Task Force on the solicitation developed by the GSA Boston Office for the joint purchase of electricity by Federal agencies in Region 1;

- The Chair of the Task Force announced the award of the Western Region Super Energy Savings Performance Contract and updated members on the status of procurements for the next Super ESPCs for the Southeast and the Rocky Mountain/Central regions;

- The New Space Working Group reported on their response to the proposed rule on Energy Efficiency Code for New Federal Residential Buildings and a representative from the Council of American Buildings Officials delivered a presentation on the development of a common international building code system; and

The Million Solar Roofs initiative was announced and its implementation in the Federal sector was discussed. 
September 17, 1997:

- Model utility service agreements and the Chair's draft testimony on utility competition for upcoming Congressional Hearings were discussed; and

- The Renewable Working Group reported that an amendment to the Federal Acquisition Regulations covering energy efficient and environmental-preferable procurement was issued on August 22, 1997.

The complete minutes of these meetings are available from the DOE Federal Energy Management Program office.

\section{Personnel and Energy Awareness Activities}

\section{Training}

During FY 1997, DOE's Federal Energy Management Program (FEMP) conducted 55 training workshops and symposia for more than 1,700 attendees in the efficient use and conservation of energy, water, and renewable energy in Federal facilities.

Nine workshops on energy savings performance contracting (ESPC) were conducted in FY 1997 for 232 participants. In each workshop, facility managers, contract specialists, and building engineers were instructed on the statutory provisions for this innovative contracting/financial method, and how to identify suitable projects. ESPC allows energy-efficient improvements to be installed by private contractors with no up-front capital costs. Among the agencies that have participated in the courses and produced project solicitations are the National Park Service in Ellis Island, New York (Department of the Interior), the Forbes Field National Guard in Topeka, Kansas (Department of Defense), and the Department of Veterans Affairs Medical Center in Washington, D.C. Each of these facilities has issued a Commerce Business Daily notice for the purpose of installing energy conservation measures.

The Federal Energy Management course provided guidance on meeting the qualifications of "trained energy manager" as defined by EPACT. Two workshops were conducted for 87 participants nationwide. In addition, the Water Resource Management course presented instruction to help Federal facility managers improve the efficiency of water use consistent with legal and environmental requirements. Three workshops were conducted for 99 participants at sites across the country.

The Designing Low Energy Buildings (Non-Residential) course was presented three times for 51 participants, in conjunction with major industry conferences. The two-day course included analyses and case studies of building design using passive solar heating, natural ventilation and cooling, and daylighting; as well as glazing and overhangs.

The Federal Relighting Initiative (FRI) course was conducted three times for a total of 62 participants. The objective was to provide guidance on energy-efficient lighting consistent with other facility lighting considerations, quality and cost, and whole building analysis. Topics 
included: basic lighting concepts; a comprehensive process for Federal relighting project development and implementation; application of the Federal Lighting Expert (FLEX) System and other analytical software tools; and the use of professional lighting design services.

Four Facility Energy Decision Screening (FEDS) workshops were held during FY 1997 for 87 attendees. This is a training course for Federal facility managers on whole-site analysis of energy conservation technical and financial opportunities utilizing the FEDS-Level 1 project screening software and the FEDS-Level 2 project implementation software.

FEMP, in conjunction with the National Institute of Standards and Technology, conducted three workshops on life-cycle costing (LCC) and building retrofit simulation for 79 students. An additional two sessions of the LCC workshop were provided for 30 students by FEMP-trained "DOE-qualified instructors." Three "A Simplified Energy Analysis Method (ASEAM)" workshops for 47 students focused on the use of the building retrofit analytical software.

The Implementing Renewable Energy Projects course was presented twice for 85 students. The Operations and Maintenance Management course was held three times for 50 individuals.

FEMP continued to offer its Water Resource Management course with three workshops for 99 attendees in FY 1997. The course is designed to assist Federal site managers and agencies in meeting the water conservation requirements of EPACT and Executive Order 12902.

During FY 1996, FEMP participated in the organization and presentation of 21 panel discussions on Federal energy efficiency, water conservation, and renewable energy topics at national energy management conferences around the country, attracting 868 attendees.

The Federal Energy Management Program continued to offer its Training Course Locator System to assist Federal agencies in training energy managers and in meeting the requirements of the EPACT. The Locator System connects those seeking particular training courses with the sponsoring organization for those courses by responding to numerous requests from Federal energy managers, utility managers, engineers, building operators, and facility personnel. 


\section{Recognition}

Outstanding accomplishments in energy efficiency and water conservation in the Federal sector were recognized with the presentation of the 1997 Federal Energy and Water Management Awards on October 23, 1997, at the National Press Club in Washington, D.C. The Awards Program is sponsored by the "656" Committee and the Department of Energy. Awards were selected from outstanding Federal energy managers and contributors who:

- Implemented proven energy efficiency, energy and water conservation techniques;

- Developed and implemented energy-related training programs and employee energy awareness programs;

- Succeeded in receiving utility incentives, or awarding ESPC and other Federal-approved performance-based energy and water contracts;

- Made successful efforts to fulfill compliance with energy and water reduction mandates;

- Improved energy efficiency or reduction in energy costs for Federal mobile equipment including aircrafts, ships, and vehicles;

- Improved tracking of energy consumption, costs and energy efficient investments;

- Provided leadership in purchasing or supplying energy-efficient, renewable energy or water-conserving products to one or more Federal agencies; and

- Demonstrated cost-beneficial landscape practices which utilize techniques that seek to minimize the adverse effects of landscaping.

Recipients of the 1997 awards were selected from 174 nominees submitted by 19 Federal agencies. Award recipients totaled 56, representing 13 different Federal agencies. Distribution of awards among the Federal agencies for accomplishments in FY 1996 is indicated below. Awards were presented to agencies in the categories shown in the exhibit below:

\begin{tabular}{|c|c|c|c|c|c|c|c|c|c|c|c|}
\hline Agency & Individual & $\begin{array}{l}\text { Small } \\
\text { Group }\end{array}$ & $\begin{array}{c}\text { Organiza- } \\
\text { tion }\end{array}$ & Total & \begin{tabular}{c|} 
Energy \\
Efficiency
\end{tabular} & ESPC & $\begin{array}{l}\text { Renew- } \\
\text { able } \\
\text { Energy }\end{array}$ & Mobility & $\begin{array}{c}\text { Water } \\
\text { Conserva- } \\
\text { tion }\end{array}$ & \begin{tabular}{|c|} 
Beneficial \\
Land- \\
scaping
\end{tabular} & Special \\
\hline DOD & 1 & & & 1 & & & & & & & 1 \\
\hline Army & 6 & 4 & 8 & 18 & 11 & 3 & 2 & & 1 & & 1 \\
\hline Navy & & & 8 & 8 & 3 & & 1 & 4 & & & \\
\hline USAF & 4 & 2 & 4 & 10 & 6 & 1 & 1 & & 2 & 1 & \\
\hline USMC & & 2 & & 2 & 1 & 1 & & & & & \\
\hline DOE & 2 & 4 & & 6 & 3 & & & & & & 2 \\
\hline $\mathrm{DOI}$ & 4 & & & 4 & 1 & & 2 & & & & 1 \\
\hline $\mathrm{DOJ}$ & 2 & 1 & & 3 & 1 & & 1 & & & & 1 \\
\hline DOT & & 1 & & 1 & & & & & & 1 & \\
\hline GSA & 1 & 5 & & 6 & 5 & & & & & & 1 \\
\hline $\mathrm{HHS}$ & 2 & & 1 & 3 & 2 & & & & & & 1 \\
\hline NASA & 1 & & & 1 & 1 & & . & & & & \\
\hline USDA & & 1 & & 1 & & & & & & & 1 \\
\hline USPS & 2 & 1 & 2 & 5 & 2 & & & & & 2 & 1 \\
\hline VA & 1 & 2 & & 3 & 1 & 2 & & & & & \\
\hline TOTAL & 26 & 24 & 22 & 72 & 37 & 7 & 7 & 4 & 3 & 4 & 10 \\
\hline
\end{tabular}


Each category contained a wide variety of projects. Examples from each award category follow.

\section{Energy Efficiency Award to Organization:}

National Institutes of Health, Department of Health and Human Services, Bethesda, Maryland. The Office of Research Services and the Division of Engineering Services teamed together to retrofit the central heating and cooling plant and upgrade the distribution system achieving savings of more than $\$ 2.4$ million per year. High-efficiency chillers and variable-frequency drive controls will reduce energy consumption by more than 20 megawatt hours and save $\$ 1$ million annually. Variable speed secondary pumping will save $\$ 720,000$ annually. Adding a steamdriven turbine will save $\$ 110,000$ annually. The chilled water flow and heat requirements have been reduced, reducing the size of distribution pipes required, saving $\$ 6$ million in construction costs.

\section{Energy Efficiency Award to Small Group:}

Militza Jennings, Jane Rodgers, Peter Gaddy, Terry Pierce, John Tate, Channing Tucker, and Edward Wasielewski, General Services Administration, San Francisco, California. A GSA/Southern California Edison partnership implemented a comprehensive energy retrofit of the 30-year-old Chet Holifield Federal Building in Laguna Niguel, saving more than $\$ 600,000$ in FY 1996. Southern California Edison contributed $\$ 900,000$ as a co-investment and financed the $\$ 4$ million capital cost. Projects included a 12,000-ton thermal energy storage system, lighting retrofits, high efficiency motors and chillers, an energy management system upgrade, and heating, ventilation, and air conditioning improvements. Electricity usage has decreased by 25 percent.

\section{Energy Efficiency Award to Individual:}

Ben Hawkins, National Park Service, Department of the Interior, Grand Lake, Colorado. Mr. Hawkins developed partnerships with several DOE offices, National Laboratories, and six State energy offices to assist eight National Parks in the Intermountain Field Region in identifying and funding cost effective energy efficiency and renewable energy projects. $\mathrm{He}$ obtained SAVEnergy audits for 20 sites. In FY 1996, nearly $\$ 311,000$ was invested, saving $\$ 66,000$ annually. Energy consumption was reduced by 20 to 30 percent in the respective buildings. Mr. Hawkins also combined the efforts of the Intermountain Field Region and the Pacific West Field Area to develop a joint super energy savings performance contract, and initiated a pilot project based on the DOE's Weatherization Assistance Program. Fifty-eight housing units and eight apartments received insulation, furnace upgrades, and other weatherization measures.

\section{Energy Savings Performance Contracting Award:}

Larry Stevenson, CoJean Sprouse, and Michael Martin, VA North Texas Health Care System, Department of Veteran Affairs, Dallas, Texas.

Taking advantage of a demand side management program offered by T.U. Electric, a $\$ 1.9$ million stratified water thermal storage system was constructed, substantially lowering energy costs at the hospital. The local utility provided $\$ 475,000$ in rebates. The system doubled the capacity of the hospital's energy plant. Savings are expected to be approximately $\$ 250,000$ per year, with a simple payback of six years. 


\section{Renewable Energy Award:}

Clifton Floyd, John Rathman, Richard Mekus, Scott Stermer, Thomas Kearns, and George Allen, Federal Bureau of Prisons, Department of Justice, Phoenix, Arizona.

The energy savings performance contract awarded for the installation, operation, and maintenance of a solar hot water system at the Federal Correctional Institute in Phoenix represents the first renewable ESPC awarded by the Federal Government. The state-of-the-art system will employ parabolic trough reflectors with a 21,000 gallon thermal storage capacity. The system will provide 80 percent of domestic hot water, reducing electrical energy consumption by 1.4 million kilowatt hours per year. Associated savings in electrical charges are expected to be $\$ 90,000$ annually.

\section{Mobility Energy Management Award:}

USS Essex (LHD 2), Department of the Navy.

In FY 1996, the USS Essex consumed 18.3 percent less fuel and saved almost $\$ 1$ million by aggressively training personnel in proper maintenance and operation of the propulsion plant and other auxiliary ship systems. Fuel oil consumption was reduced by 1.2 million gallons, saving almost $\$ 895,000$, by overhauling the propulsion systems and running the ship at economical speeds during long transits. Other measures included weekly equipment monitoring, training, lighting reductions, streamlining the air conditioning system, and installing low-flow showerheads.

\section{Water Management Award:}

Fort Eustis, Department of the Army, Fort Eustis, Virginia.

The Directorate of Public Works implemented water projects that reduced consumption by almost 26 percent, saving 147 million gallons of water annually. A water conservation task force commissioned a water detection survey and corrected the identified leaks. Other initiatives included adjusting the operation of the distribution system to reduce overflow and waste, installing water conservation kits in housing units, and filtering and reusing water for the swimming pool. An investment of only $\$ 100,000$ will save more than $\$ 340,000$ annually over the next 20 years.

\section{Beneficial Landscaping Practices Award:}

Lake Havasu City Post Office, United States Postal Service, Lake Havasu, Arizona.

By using xeriscape landscaping principles, water and landscape maintenance costs will be reduced by approximately $\$ 500$ per month, a savings of 50 percent. Native plants, obtained from the Bureau of Reclamation, were positioned to reduce energy bills through shading. A leaky, inefficient watering system was replaced with a new irrigation system. Pesticide and fertilizer use was reduced. The Postal Service leveraged $\$ 10,000$ in funding with $\$ 10,000$ from a SAVEnergy grant. The remaining $\$ 30,000$ cost was contributed by Lake Havasu Area Chamber of Commerce, the City of Lake Havasu, the Bureau of Land Management, and Arbourtech Landscaping. 
Special Award:

Betsy Gayle, Defense Supply Center, Department of Defense, Richmond, Virginia.

In 1996, on her own initiative, Ms. Gayle began cataloguing the energy efficiency ratios of new air conditioners in the Federal Logistics Information Service (FLIS) database. Previously, energy efficiency information was rarely included as part of the FLIS data for energy using products, effectively precluding Federal customers from evaluating Defense Logistics Agency products based on energy consumption and efficiency. After including the energy efficiency ratios in a miscellaneous section of each record, Ms. Gayle instituted an official "Master Requirement Code" for the ratios. This information will be requested automatically of all manufacturers and will be available to Federal customers. Her model is being duplicated by DOE's FEMP for dozens of other energy-using products and equipment for the Federal Procurement Challenge.

\section{Energy Awareness}

The Federal Government, as the largest single employer in the United States, has the responsibility to set an example for the nation by conducting energy awareness programs. Most agencies have ridesharing, carpooling, and/or public transportation programs in effect. Many agencies also participate in recycling programs. The following exhibit shows the employee awareness activities at the various Federal agencies.

\begin{tabular}{|c|c|c|c|c|c|}
\hline Agency & $\begin{array}{c}\text { Award } \\
\text { Programs }\end{array}$ & Recycling & Ridesharing & $\begin{array}{c}\text { Transit } \\
\text { Subsidies }\end{array}$ & $\begin{array}{l}\text { Information } \\
\text { Dissemination }\end{array}$ \\
\hline USDA & $\checkmark$ & $\checkmark$ & $\checkmark$ & & $\checkmark$ \\
\hline DOC & $\checkmark$ & $\checkmark$ & $\checkmark$ & & \\
\hline DOD & $\checkmark$ & $\checkmark$ & 1 & $\checkmark$ & $\checkmark$ \\
\hline DOE & $\checkmark$ & $\checkmark$ & $\checkmark$ & $\checkmark$ & $\checkmark$ \\
\hline HHS & $\checkmark$ & $\checkmark$ & & & \\
\hline HUD & $\checkmark$ & $\checkmark$ & $\checkmark$ & $\checkmark$ & \\
\hline DOI & $\checkmark$ & $\checkmark$ & $\checkmark$ & $\checkmark$ & $\checkmark$ \\
\hline DOJ & $\checkmark$ & $\checkmark$ & $\checkmark$ & & $\checkmark$ \\
\hline DOL & $\checkmark$ & $\checkmark$ & $\checkmark$ & $\checkmark$ & \\
\hline ST & & $\checkmark$ & $\checkmark$ & & \\
\hline DOT & $\checkmark$ & $\checkmark$ & $\checkmark$ & $\checkmark$ & $\checkmark$ \\
\hline TRSY & & $\checkmark$ & $\checkmark$ & $\checkmark$ & $\checkmark$ \\
\hline VA & & $\checkmark$ & & & \\
\hline EPA & $\checkmark$ & $\checkmark$ & $\checkmark$ & $\checkmark$ & $\checkmark$ \\
\hline GSA & $\checkmark$ & $\checkmark$ & $\checkmark$ & & \\
\hline NASA & $\checkmark$ & $\checkmark$ & $\checkmark$ & $\checkmark$ & $\checkmark$ \\
\hline NARA & $\checkmark$ & & & & \\
\hline NRC & & $\checkmark$ & $\checkmark$ & $\checkmark$ & $\checkmark$ \\
\hline PCC & & & & & $\checkmark$ \\
\hline RRB & & $\checkmark$ & & $\checkmark$ & \\
\hline SSA & $\checkmark$ & $\checkmark$ & & & \\
\hline TVA & & $\checkmark$ & $\checkmark$ & & $\checkmark$ \\
\hline USPS & $\checkmark$ & $\checkmark$ & $\checkmark$ & $\checkmark$ & $\checkmark$ \\
\hline
\end{tabular}




\section{Federal Energy Saver Showcase Facilities}

Section 307 of Executive Order 12902 requires that each agency which constructs at least five buildings in a year shall designate at least one building, at the earliest stage of development, to be a showcase highlighting advanced technologies and practices for energy efficiency, water conservation, or use of solar and other renewable energy. Furthermore, it requires that the agencies attempt to incorporate cogeneration, solar and other renewable energy technologies, and indoor air quality improvements. Selection of such buildings are based on considerations such as the level of non-Federal visitors, historical significance, and the likelihood that visitors will learn from the demonstration and initiate similar projects. The Order charges each agency to develop and implement plans in cooperation with DOE and, where appropriate, in consultation with the General Services Administration, the Environmental Protection Agency, and other appropriate agencies to determine strategies to implement these demonstrations.

The showcase facilities designated in FY 1997 feature a wide variety of approaches and technologies at widely disparate Federal sites. The latest Federal Energy Saver Showcases reach further across the country, extending into 19 states. Although many showcase projects carry out conventional energy saving measures, some also feature cutting-edge technologies. For example, GSA is partnering with their servicing utility and DOE to illuminate the exterior of the Alexander Hamilton Customs House with a sulfur lamp. The Department of Defense has designated three phosphoric fuel cell power plants as showcases. To date, these projects have saved the DOD nearly $\$ 250,000$, and have proven that fuel cells are a highly efficient, environmentally clean, and cost effective method of electricity generation. By installing this technology, DOD has taken the lead in increasing fuel cell use across the United States.

Twenty percent of the showcases have chosen geothermal technology to heat and cool their buildings. This technology is becoming more popular within the Federal sector, and is providing significantly lower utility bills to the energy managers at the Department of the Interior and the Department of Energy. No pollutants are added to the environment by these systems, and during their 20-year equipment life, geothermal heat pump systems save energy, dollars, and reduce emissions at a rate significantly lower than comparable heating and cooling systems.

Renewable energy technologies are also prominent. The Environmental Protection Agency's Ada and Narragansett Laboratories are integrating solar water heating technology. The passive solar design used in the Department of the Interior's Prairie Learning Center will save the Fish and Wildlife Service facility more than 400,000 kilowatt hours and $\$ 17,000$ in annual energy consumption.

The success of these projects reveal the strength of partnering with utilities, national laboratories, energy services companies, other agencies, and FEMP programs such as the SAVEnergy Action Plan audit program. Design assistance, low- or no-cost energy audits, incentives, and funding are available to make these projects a reality. By using conventional and alternative methods that save energy and money, tapping into renewable energy sources, and conserving water, the Federal Government has taken the lead in demonstrating to the nation the benefits of implementing energy saving technologies. 
A comprehensive list of Federal showcase facilities designated in FY 1997 follows:

\section{FY 1997 Federal Energy Saver Showcase Facilities}

USDA

DOD

U.S. Army Corps of Engineers

U.S. Army Construction Engineering Research

Laboratories

EPA

GSA

HHS

DOI, Bureau of Reclamation

DOI, Fish and Wildlife Service

DOI, U.S. Geological Survey
Beltsville Office Complex, College Park, Maryland

Directorate of Public Works, Barracks Buildings 3214, 6921A, and 6944, Fort Campbell, Kentucky

New Tertiary Wastewater Treatment Plant, Edwards Air Force Base, California

W.G. Huxtable Pumping Plant, Marianna, Arkansas

Graham Burke Pumping Plant, Elaine, Arkansas

Building 3502, Defense Finance and Accounting Service, Limestone, Maine

Steam Generator Installation, Picatinny Arsenal, New Jersey

Fort Polk Earth Coupled Heat Pump Project, Fort Polk, Louisiana

Central Energy Facility, Building 1941, Fort Polk, Louisiana

O'Donnell Heights Family Housing Revitalization Project, Fort Riley, Kansas

Central Energy Plant \#2, Fort Jackson, South Carolina

Harrison Villa, Fort Lee, Virginia

Boiler Plant Project, Natick Soldier Systems Command, Massachusetts

Boiler Plant Project, Picatinny Arsenal, New Jersey

Boiler Plant Project, West Point Military Academy, New York

Subsurface Protection and Remediation Division, Ada, Oklahoma

Atlantic Ecology Division, Office of Research and Development, Narragansett, Rhode Island

Chet Holifield Federal Building, Laguna Niguel, California

Alexander Hamilton Customs House, New York, New York

Hawthorne Federal Building, Hawthorne, California

Tampa Federal Courthouse II, Tampa, Florida

Frederick Cancer Research and Development Center, Frederick, Maryland

Davis Dam, Bullhead City, Arizona

Centennial Job Corps Center, Nampa, Idaho

Wichita Mountains Visitor Center, Indiahoma, Oklahoma

Prairie Learning Center, Prairie City, Iowa

EROS Data Center, Mundt Federal Building, Sioux Falls, South Dakota 


\section{E. Funding for Energy Efficiency in Buildings and Facilities}

During FY 1997, Federal agencies had three primary options for financing energy efficiency, water conservation, and renewable energy projects in buildings and facilities: direct appropriated funding, energy savings performance (ESP) contracts, and utility-sponsored demand side management (DSM) incentives. The latter two options utilize non-Government sources of funding and can be used to supplement Government funding. Each of these three sources can be combined with another. Formerly, the DOE's Federal Energy Efficiency Fund grant program was a fourth option available to agencies for funding projects; however, there were no appropriations for the Fund in FY 1997.

To the extent that agencies have been able to provide complete reporting, funding from the three sources totaled approximately \$229.3 million in FY 1997.

\section{Direct Appropriations}

The National Energy Conservation Policy Act requires each agency, in support of the President's annual budget request to Congress, to specifically set forth and identify funds requested for energy conservation measures. Table 3-A presents agency funding (in nominal dollars) reported from FY 1985 through FY 1997 for energy conservation retrofits and capital equipment. Table 3-B presents the same information in constant 1997 dollars. In constant dollars, funding for energy conservation declined from $\$ 370.4$ million in FY 1985 to a low of $\$ 65.4$ million in FY 1989. Reports from Federal agencies indicated that $\$ 200.4$ million was spent on retrofit expenditures in FY 1997, compared with $\$ 182.9$ million in FY 1996. In some cases, the data provided by the agencies include funding from operation and maintenance accounts that was specifically identified as contributing to energy efficiency. Figure 4 illustrates agency spending trends for the five largest energy-consuming agencies and the remaining group of Federal agencies.

The Defense Department funded $\$ 119.0$ million in expenditures for energy efficiency projects in FY 1997, $\$ 4.2$ million more than the previous year.

No direct funding was appropriated for the Department of Energy in FY 1997 for retrofit projects in buildings and metered process facilities.

The General Services Administration funded $\$ 20.0$ million for 92 energy conservation projects in FY 1997. GSA received rebates totaling $\$ 532,587$, in addition to the energy savings accrued from these projects. The rebates were substantially less than in years past, as the utility industry is moving away from utility incentive programs. 
Table 3-A

Agency Expenditures for Energy Conservation Retrofits and Capital Equipment, FY 1985 through FY 1997 (Thousands of Nominal Dollars)

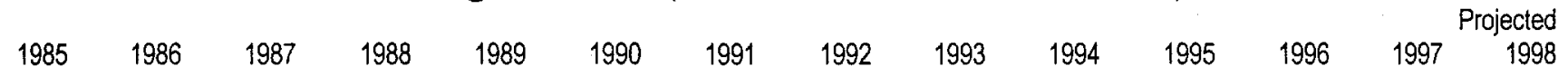

\begin{tabular}{|c|c|c|c|c|c|c|c|c|c|c|c|c|c|c|}
\hline$D O C$ & 0 & 0 & 0 & 0 & 0 & 0 & 0 & 872 & 0 & 51 & 0 & 0 & NA & NA \\
\hline DOD & $\uparrow 36,100$ & 120,000 & 5,550 & 5,280 & 1,500 & 1,020 & 10,000 & 49,669 & 14,444 & 109,000 & 189,600 & 112,487 & 118,970 & 83,033 \\
\hline DE & 14,800 & 14,500 & 16,500 & 18,900 & 19,400 & 19,500 & 20,400 & 20,650 & 20,950 & 24,850 & 30,200 & 0 & 0 & 0 \\
\hline ام & 3,198 & 5,535 & 0 & 0 & 4,338 & 0 & 1,272 & 9,800 & 4,859 & 1,662 & 779 & 891 & 0 & 0 \\
\hline OJ & 0 & 0 & 0 & 195 & 484 & 6,100 & 26,400 & 0 & N/A & 1,284 & 994 & 1,559 & 2,091 & 2,000 \\
\hline DL & 238 & 31 & 106 & 142 & 584 & 17 & 35 & 16 & 0 & 0 & N/A & 366 & 0 & \\
\hline DT & 13,650 & 15,000 & 12,104 & 12,700 & 2,908 & 0 & 460 & 143 & 593 & 5,970 & 3,793 & 2,585 & 3,176 & 3,205 \\
\hline A & 0 & 0 & 0 & 0 & 0 & 0 & 0 & 0 & 500 & 0 & 1,720 & 1,600 & 1,600 & 1,600 \\
\hline SA & 6,700 & 6,100 & 2,900 & 9,400 & 4,868 & 11,125 & 30,123 & 37,000 & 30,000 & 37,000 & 7,242 & 7,400 & 20,000 & NA \\
\hline is & 0 & 0 & 0 & 427 & 427 & 427 & 427 & 0 & 1,813 & 1,915 & 1,271 & 2,676 & 2,879 & 2,245 \\
\hline JD & 0 & 0 & 0 & 0 & 0 & 0 & 0 & 0 & 43 & 30 & 43 & 0 & 2,418 & 77 \\
\hline ASA & 11,800 & 12,100 & 1,700 & 1,400 & 4,499 & 2,943 & 7,556 & 7,086 & 25,072 & 24,658 & 20,666 & 30,266 & 15,919 & 13,997 \\
\hline CC & 1,274 & 73 & 1,174 & 600 & 378 & 361 & 807 & 249 & 500 & 608 & 14 & 23 & 3 & 104 \\
\hline RB & 0 & 0 & 0 & 0 & 0 & 0 & 0 & 0 & 16 & 13 & 33 & 0 & 38 & \\
\hline TATE & 0 & 0 & 0 & 0 & 0 & 0 & 0 & 0 & 0 & 67 & 0 & 0 & 1,902 & 3,000 \\
\hline & 0 & 0 & 2,977 & 2,393 & 2,823 & 1,134 & 836 & 0 & 1,344 & 4,826 & 2,810 & 170 & 2,990 & 70 \\
\hline & 0 & 0 & 0 & 0 & 0 & 0 & 0 & 0 & 475 & 844 & 4,277 & 522 & 1,158 & 63 \\
\hline SDA & 2,500 & 0 & 0 & 500 & 500 & 1,547 & 1,752 & 7,300 & 7,045 & 7,277 & 2,894 & 5.983 & 3,891 & 2.300 \\
\hline & 55,300 & 9,300 & 5,100 & 3,800 & 4,000 & 4,000 & 4,000 & 2,293 & 1,116 & 1,123 & 10,050 & 9,000 & 16,000 & $\mathrm{~N}$ \\
\hline & 13,000 & 11,500 & 9,500 & 9,860 & 5,500 & 11,200 & 9,970 & 10,000 & 12,100 & 9,050 & 11,960 & 3,700 & 7,400 & 11,70 \\
\hline & 258,560 & 194,139 & 57,611 & 65,597 & 52,209 & 59,374 & 114,038 & 145,078 & 120,870 & 230,228 & 288,346 & 179,228 & 200,435 & 124,61 \\
\hline
\end{tabular}

Table 3-B

Agency Expenditures for Energy Conservation Retrofits and Capital Equipment,

FY 1985 through FY 1997 (Thousands of Constant 1997 Dollars)

\begin{tabular}{|c|c|c|c|c|c|c|c|c|c|c|c|c|c|}
\hline \multirow[b]{2}{*}{1985} & \multirow[b]{2}{*}{1986} & \multirow[b]{2}{*}{1987} & \multicolumn{3}{|c|}{ r } & \multirow[b]{2}{*}{1991} & \multirow[b]{2}{*}{1992} & \multirow[b]{2}{*}{1993} & \multirow[b]{2}{*}{1994} & \multirow[b]{2}{*}{1995} & \multirow[b]{2}{*}{1996} & \multicolumn{2}{|c|}{ Projected } \\
\hline & & & 1988 & 1989 & 1990 & & & & & & & 1997 & 1998 \\
\hline 0 & 0 & 0 & 0 & 0 & 0 & 0 & 980 & 0 & 54 & 0 & 0 & 0 & \\
\hline 986 & 167,364 & 7,510 & 6,893 & 1,880 & 1,224 & 11,547 & 55,808 & 15,820 & 115,711 & 197,706 & 114,783 & 118,970 & 81,405 \\
\hline 1,203 & 20,223 & 22,327 & 24,674 & 24,311 & 23,409 & 23,557 & 23,202 & 22,946 & 26,380 & 31,491 & 0 & 0 & 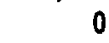 \\
\hline 4,582 & 7,720 & 0 & 0 & 5,436 & 0 & 1,469 & 11,011 & 5,322 & 1,764 & 812 & 909 & 0 & 0 \\
\hline 0 & 0 & 0 & 255 & 607 & 7,323 & 30,485 & 0 & $n$ & 1,363 & 1,036 & 1,591 & 2,091 & 1,961 \\
\hline 341 & 43 & 143 & 185 & 732 & 20 & 40 & 18 & 0 & 0 & 0 & 373 & 0 & 0 \\
\hline 19,556 & 20,921 & 16,379 & 16,580 & 3,644 & 0 & 531 & 161 & 649 & 6,338 & 3,955 & 2,638 & 3,176 & 3,142 \\
\hline & 0 & 0 & 0 & 0 & 0 & 0 & 0 & 548 & 0 & 1,794 & 1,633 & 1,600 & 1,569 \\
\hline 9,599 & 8,508 & 3,924 & 12,272 & 6,100 & 13,355 & 34,784 & 41,573 & 32,859 & 39,278 & 7,552 & 7,551 & 20,000 & 0 \\
\hline 0 & 0 & 0 & 557 & 535 & 513 & 493 & 0 & 1,986 & 2,033 & 1,325 & 2,731 & 2,879 & 2,201 \\
\hline 0 & 0 & 0 & 0 & 0 & 0 & 0 & 0 & 47 & 32 & 45 & 0 & 2,418 & 75 \\
\hline 16,905 & 16,876 & 2,300 & 1,828 & 5,638 & 3,533 & 8,725 & 7,962 & 27,461 & 26,176 & 21,550 & 30,884 & 15,919 & 13,723 \\
\hline 1,825 & 102 & 1,589 & 783 & 474 & 433 & 932 & 280 & 548 & 645 & 15 & 23 & 3 & 102 \\
\hline 0 & 0 & 0 & 0 & 0 & 0 & 0 & 0 & 18 & 14 & 34 & 0 & 38 & 22 \\
\hline 0 & 0 & 0 & 0 & 0 & U & 0 & 0 & 0 & 71 & 0 & 0 & 1,902 & 2,941 \\
\hline 0 & 0 & 4,028 & 3,124 & 3,538 & 1,361 & 965 & 0 & 1,472 & 5,123 & 2,930 & 173 & 2,990 & 689 \\
\hline 0 & 0 & 0 & 0 & 0 & 0 & 0 & 0 & 520 & 896 & 4,460 & 533 & 1,158 & 618 \\
\hline 582 & 0 & 0 & 653 & 627 & 1,857 & 2,023 & 8,202 & 7,716 & 7,725 & 3,018 & 6,105 & 3,891 & 2,255 \\
\hline 226 & 12,971 & 6,901 & 4,961 & 5,013 & 4,802 & 4,619 & 2,576 & 1,223 & 1,192 & 10,480 & 9,184 & 16,000 & 0 \\
\hline 8,625 & 16,039 & 12,855 & 12,872 & 6,892 & 13,445 & 11,513 & 11,236 & 13,253 & 9,607 & 12,471 & 3,776 & 7,400 & 11,471 \\
\hline & 106 & 38 & 85,636 & $42 \quad$ & 71,277 & 37,684 & 63,009 & 132,388 & , 403 & 300,674 & 2,886 & 35 & 22,17 \\
\hline
\end{tabular}

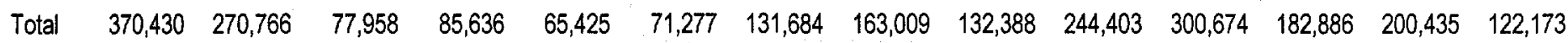

Notes: Bold indicates top five energy users in buildings and facilities (DOD, DOE, VA, USPS, GSA). In past years, DOE also included

funds for energy surveys. Does not include energy savings performance contracts and utility demand side management incentives.

Source: Federal Agency Annual Energy Management Data Reports 
FIGURE 4

ENERGY CONSERVATION RETROFIT EXPENDITURES

(In Constant 1997 Dollars)

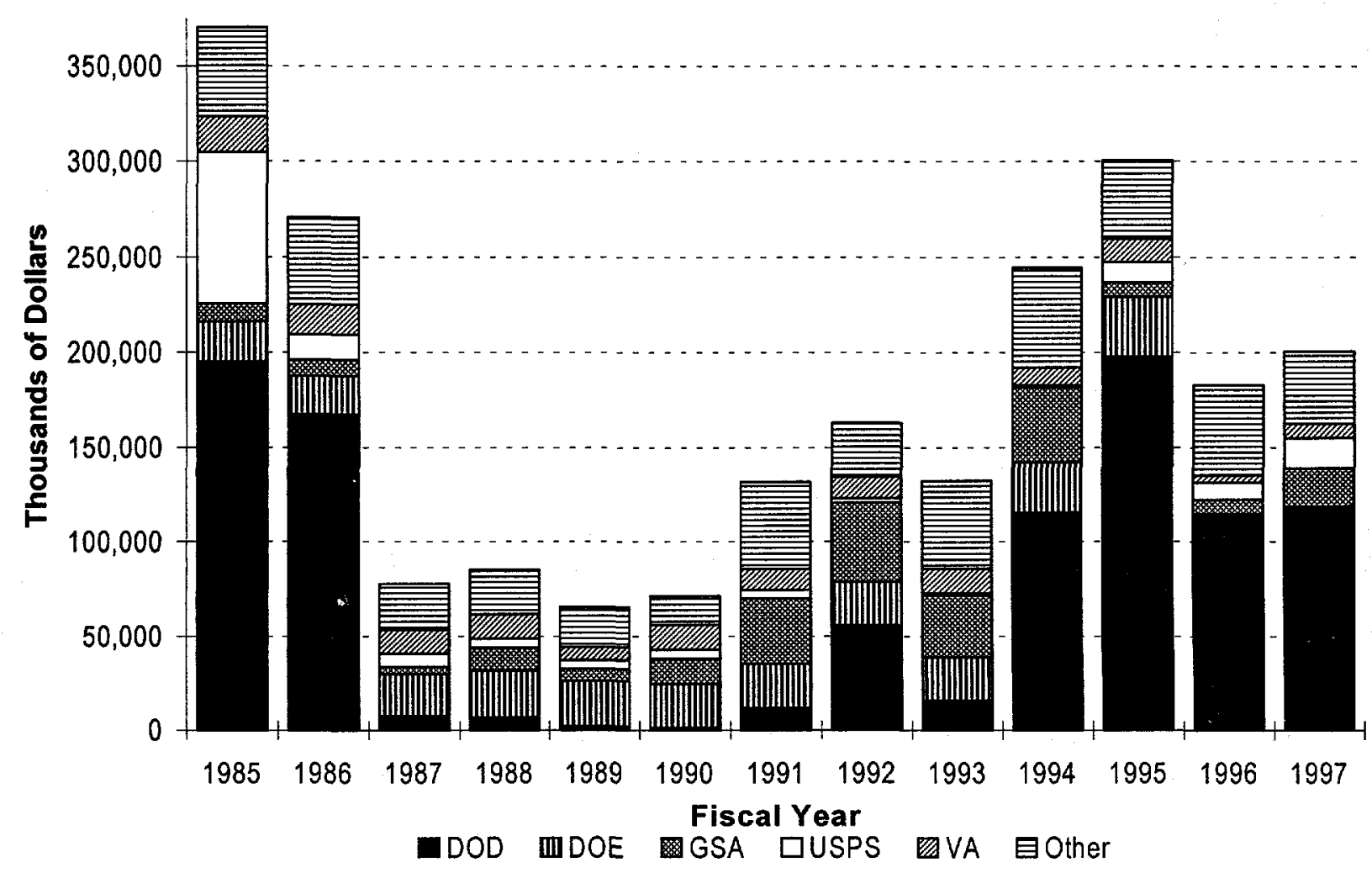

Source: Federal Agency Annual Energy Management Data Reports

\section{Federal Energy Efficiency Fund}

The Federal Energy Efficiency Fund (Fund) was established by section 152 of EPACT, which amended section 546 of NECPA, to provide grants to agencies to assist them in meeting the mandated energy efficiency and water conservation requirements. The limited spending authority available in FY 1994 and FY 1995 was applied to those proposals which were most competitive, considering the five following factors:

1. The cost-effectiveness of the project (saving-to-investment ratio).

2. The net dollar cost savings to the Federal Government.

3. The amount of energy savings to the Federal Government.

4. The amount of funding committed by the agency requesting financial assistance.

5. The amount of funding leveraged from non-Federal sources.

No spending authority has been provided beyond FY 1995. A total of 114 proposals were received during FY 1994 and FY 1995 and Fund grants were provided for 37 projects. Of these, 
35 projects provide energy savings of 5.8 trillion Btu and two projects result in water conservation in the amount of 738 million cubic feet, with an estimated energy and water cost savings of $\$ 54$ million (before payback of the initial investment) over the useful lives of the projects. The total Fund investment to realize these savings was $\$ 7.9$ million, which leveraged $\$ 3.6$ million in Federal-agency funding and $\$ 0.9$ million in non-Federal funding. The projects encompass 14 states and the District of Columbia, with one project located in the Caribbean. A summary of the funded projects is shown on the next page.

EPACT, 42 U.S.C. $\S 8258$, requires energy and cost savings to be reported annually after completion of construction, for each project funded under the Federal Energy Efficiency Fund. Of the 37 funded projects, 23 are complete and operational, realizing annual energy and cost savings which equal or exceed the values projected in the original proposals for Fund grants. Six energy efficient lighting projects, two water projects, and one each HVAC, chiller, and natural gas conversion projects remain under construction for completion by the end of FY 1998. These projects have been integrated into other non-Fund building upgrades funded by the respective agencies, resulting in longer time periods required for completion. In some cases, mission requirements have also limited building access.

Three Federal Energy Efficiency Fund projects will each put in place one base-wide energy savings performance contract (ESPC) for the U.S. Coast Guard in Honolulu, HI, and the National Park Service for the Presidio of San Francisco, CA, and two ESPCs will be put in place for the U.S. Army at Fort Huachuca, AZ. One of the Fort Huachuca projects and the U.S. Coast Guard project will install renewable energy solar hot water systems. 


\section{Federal Energy Efficiency Fund Projects - FY 1997 Status}

\begin{tabular}{|c|c|c|c|c|}
\hline $\begin{array}{ll} & \\
4 & \text { Agency }\end{array}$ & State: & $\begin{array}{l}\text { Broject Bescription } \\
\text { Pros }\end{array}$ & $\begin{array}{l}\text { Funds } \\
\text { Awarded }\end{array}$ & $\begin{array}{l}\text { Installation } \\
\text { Status } \\
\text { (Percent } \\
\text { Complete) }\end{array}$ \\
\hline DOC - NOAA & WA & NW Fish Science Center - Fish Culture System & $\$ 471,399$ & $98 \%$ \\
\hline DoD - US Army & $A Z$ & Solar and Base-wide Upgrades & $\$ 310,000$ & $80 \%$ \\
\hline DOI - National Park Service & UT & Dangling Rope Marina - PV System & $\$ 350,000$ & $100 \%$ \\
\hline DOI - National Park Service & $\mathrm{DC}$ & White House - Transformer \& NPS Detailee & $\$ 74,000$ & $100 \%$ \\
\hline DOI - National Park Service & WY & Yellowstone NP - Lighting, Heat, \& Insulation & $\$ 455,665$ & $95 \%$ \\
\hline DOI - National Park Service & WY & Yellowstone NP - Phase 2 Lighting, Heat, \& Insulation & $\$ 174,500$ & $85 \%$ \\
\hline DOI - National Park Service & $\mathrm{CA}$ & Channel Island Santa Rosa Island - Wind \& PV System & $\$ 272,394$ & $100 \%$ \\
\hline DOI - National Park Service & $\mathrm{CA}$ & Yosemite National Park - Lighting Retrofit & $\$ 73,621$ & $100 \%$ \\
\hline DOI - National Park Service & $\mathrm{CA}$ & Golden Gate NRA, Presidio - Lighting Retrofit & $\$ 175,000$ & $50 \%$ \\
\hline DOL - Job Corps Center & MT & Electric to Natural Gas Conversion & $\$ 225,000$ & $60 \%$ \\
\hline DOT - FAA & $\mathrm{OH}$ & Lighting Retrofit & $\$ 103,706$ & $0 \%$ \\
\hline DOT - Coast Guard & AK & Used Oil Processing Facility & $\$ 530,000$ & $100 \%$ \\
\hline DOT - Coast Guard & MD & USCG Yard, Lighting Retrofit & $\$ 80,671$ & $100 \%$ \\
\hline DOT - Coast Guard & $\mathrm{HI}$ & Housing Area - Solar Water Heating & $\$ 100,000$ & $50 \%$ \\
\hline Treasury - US Mint & $\mathrm{PA}$ & Lighting Retrofit & $\$ 103,180$ & $100 \%$ \\
\hline Exec. Residence Agency & $\mathrm{DC}$ & White House - Lighting Retrofit \& Refrigerator & $\$ 50,477$ & $100 \%$ \\
\hline HHS - NIH/National Cancer Inst. & MD & Chiller Installation & $\$ 283,463$ & $55 \%$ \\
\hline HHS - NIH/National Cancer Inst. & MD & Occupancy Sensor Installation & $\$ 129,090$ & $4 \%$ \\
\hline NASA - Dryden & $\mathrm{CA}$ & Edwards AFB Bldg \#4800 Lighting Retrofit & $\$ 265,414$ & $100 \%$ \\
\hline NASA - Goddard & $M D$ & Bldg's \#17, 21, 22, \& 23 Lighting Retrofit & $\$ 286,715$ & $97 \%$ \\
\hline NASA - Goddard & $\mathrm{VA}$ & E-Building Complex Lighting Retrofit & $\$ 94,812$ & $100 \%$ \\
\hline NASA - Kennedy & FL & Bldg M7-505 Lighting Retrofit & $\$ 144,500$ & $100 \%$ \\
\hline NASA - Kennedy & $F$ & Bidg M6-336 Lighting \& HVAC Retrofits & $\$ 41,800$ & $100 \%$ \\
\hline NASA - Kennedy & $F L$ & Bldgs M6-339 \& M7-581 Lighting Retrofit & $\$ 36,942$ & $100 \%$ \\
\hline NASA - Kennedy & $\mathrm{FL}$ & Hanger L, Bldg 1732 Lighting \& HVAC Mods & $\$ 88,900$ & $100 \%$ \\
\hline NASA - Kennedy & $\mathrm{FL}$ & Launch Complex 39 Lighting Retrofit & $\$ 106,050$ & $100 \%$ \\
\hline NASA - Marshall & $\mathrm{AL}$ & Bldg. 4610 Lighting Modifications & $\$ 120,000$ & $70 \%$ \\
\hline NASA - Marshall & $\mathrm{AL}$ & Building 4250 Water Conservation & $\$ 116,500$ & $70 \%$ \\
\hline National Gallery of Art & $D C$ & HVAC Automation System & $\$ 2,000,000$ & $35 \%$ \\
\hline Smithsonian Institution & MD & Support Center - Phases 3, 4, \& 5 Lighting & $\$ 100,000$ & $100 \%$ \\
\hline Agency for Int"I Development & Jamaica & Executive Office Bldg - Lighting \& Windows & $\$ 69,798$ & $100 \%$ \\
\hline USDA - Agric. Research Service & MD & Bldg 011A - Fluorescent Lamp Retrofit & $\$ 3,640$ & $100 \%$ \\
\hline USDA - Agric. Research Service & MD & Bldg 011A - Lighting Occupancy Sensors & $\$ 33,326$ & $100 \%$ \\
\hline USDA - Forest Service & $A Z$ & Apache-Sitgreaves NF Lighting Retrofit & $\$ 35,000$ & $100 \%$ \\
\hline USDA - Forest Service & $A Z$ & Kaibab NF - Replace Telephone Switch & $\$ 66,500$ & $100 \%$ \\
\hline USDA - Forest Service & $\mathrm{CA}$ & Shasta-Trinity NF - NCSC Lighting Retrofit & $\$ 28,500$ & $100 \%$ \\
\hline US Soldiers \& Airmen's Home & $\mathrm{DC}$ & Ljghting Retrofit & $\$ 274,677$ & $100 \%$ \\
\hline
\end{tabular}




\section{Energy Savings Performance Contracting}

Section 155 of EPACT amended Title VIII of NECPA, sections 801 and 804, relating to shared energy savings contracts. Section 801 , as amended, gives agencies the authority to enter into energy savings performance contracts (ESPCs) and describes the methodology of contract implementation. Energy savings performance contracts are designed to reduce the cost of energy in Federal buildings without capital investment by the building owner. Typically, the terms of such a contract provide for contractor purchase, installation and maintenance of energy conservation measures with a guarantee of annual energy cost savings in consideration for a share of such savings. Under these contracts, the contractor is expected to bear the risk of performance, make a significant initial investment, guarantee significant energy savings to the Government agency, and from these savings, the agency makes a payment to the contractor.

Section 801 required DOE to issue appropriate rules containing: (1) procedures and methods for selecting, monitoring and terminating energy savings performance contracts; and (2) "substitute regulations" for provisions of the Federal Acquisition Regulation (FAR) which are inconsistent with the intent of section 801 as amended and which may be revised consistent with laws governing Federal procurement.

On April 10, 1995, DOE published in the Federal Register (10 CFR Part 436) a final rule that sets forth the regulations for energy savings performance contracting and achieved the directive to substitute regulations for certain provisions in the FAR. On April 18, 1995, DOE published a correction that changed the effective date of the final rule from May 10 to April 10, 1995. The ESPC regulation establishes a pilot program to test for five years the concept of accelerating installation of energy conservation measures in existing Federally owned buildings through energy savings performance contracts. The Federal Acquisition Regulatory Council concurred with the final rule.

DOE released with the ESPC regulations revised versions of model solicitations. These solicitations provide uniform formats and standardized contract provisions recommended for Federal agency use in energy savings performance contracts. The model solicitations include some provisions that have been determined necessary to accommodate the unique nature of energy conservation services which often require third-party financing.

An application process for a Qualified List of Energy Service Companies (ESCOs) was also released with the ESPC regulations. Only firms on the Qualified List may receive an ESPC award. Firms that wish to be on the Qualified List must submit an application to DOE and possess the required experience and expertise. The List is continually updated.

Inherent to implementation of the ESPC regulation is the necessity for action by senior agency officials, agency priority on employing energy savings performance contracts, development and maintenance of trained and dedicated procurement personnel, and accountability for results. FY 1997 completes the third year of the five year ESPC pilot program. During FY 1997 the award of 21 ESPCs resulted in planned contractor investment of at least $\$ 26.5$ million, providing the Government with an opportunity to save millions of dollars in energy costs during the life of the contracts. The ESPCs awarded during FY 1997 included seven by the U.S. Postal Service, three 
by the Department of Veterans Affairs, two (site-specific) contracts by the Department of Energy, three by the Department of the Interior, three by the Department of Defense, and one each by the Department of Justice, Department of the Treasury, and General Services Administration.

\section{Energy Savings Performance Contracts Awarded in FY 1997}

\begin{tabular}{|c|c|c|c|}
\hline Project Name/Location & Project Description & $\begin{array}{l}\text { Contractor } \\
\text { Investment }\end{array}$ & $\begin{array}{c}\text { Government } \\
\text { Share of Savings }\end{array}$ \\
\hline $\begin{array}{l}\text { DOD, Army, Ft. Huachucha, Sierra } \\
\text { Vista, AZ }\end{array}$ & All energy savings for entire base & Max. \$10M & TBD \\
\hline $\begin{array}{l}\text { DOD, Navy, Naval Surface Warfare } \\
\text { Center, Crane, IN }\end{array}$ & $\begin{array}{l}\text { Boiler replacement, DDC and energy } \\
\text { management control system }\end{array}$ & $\$ 1.9 \mathrm{M}$ & TBD \\
\hline $\begin{array}{l}\text { DOD, DLA, Defense Supply Center } \\
\text { Richmond, VA }\end{array}$ & TBD & TBD & TBD \\
\hline DOE, Hanford Site, Richland, WA & $\begin{array}{l}\text { Steam system improvements, site-wide } \\
\text { comprehensive measures }\end{array}$ & TBD & $\mathrm{TBD}$ \\
\hline $\begin{array}{l}\text { DOE, Lawrence Livermore National } \\
\text { Laboratory, Livermore, CA }\end{array}$ & $\begin{array}{l}\text { Comprehensive energy efficiency } \\
\text { measures }\end{array}$ & TBD & TBD \\
\hline $\begin{array}{l}\text { DOE, Regional Super ESPC, } \\
\text { Western Region (AK, AZ, CA, HI, } \\
\text { ID, NV, OR, WA, U.S. Pacific Trust } \\
\text { Territories) }\end{array}$ & Wide-ranging energy savings measures & TBD & TBD \\
\hline $\begin{array}{l}\text { DOI, Weber Basin Job Corps, } \\
\text { Ogden, UT }\end{array}$ & Lighting retrofit & TBD & $\begin{array}{l}\text { All savings dedicated to } \\
\text { repayment }\end{array}$ \\
\hline $\begin{array}{l}\text { DOI, Collbran Job Corps, Collbran, } \\
\text { CO }\end{array}$ & Lighting retrofit & TBD & $\begin{array}{l}\text { All savings dedicated to } \\
\text { repayment }\end{array}$ \\
\hline DOI, Provo Area Office, Provo, UT & Lighting retrofit & TBD & $\begin{array}{l}\text { All savings dedicated to } \\
\text { repayment }\end{array}$ \\
\hline $\begin{array}{l}\text { DOJ, Federal Corrections Institute, } \\
\text { Phoenix, AZ }\end{array}$ & Solar hot water heating system & $\$ 650,000$ & $10 \%$ of total savings \\
\hline $\begin{array}{l}\text { GSA, Deconcini Courthouse and } \\
\text { Federal Building, Tucson, AZ }\end{array}$ & $\begin{array}{l}\text { New construction ESPC (controls, } \\
\text { chillers, and VAVs) }\end{array}$ & $\$ 1,624,787$ & $\$ 794,531$ \\
\hline $\begin{array}{l}\text { Treasury, Bureau of the Mint, } \\
\text { Philadelphia, PA }\end{array}$ & $\begin{array}{l}\text { Lighting retrofit, chiller replacement, } \\
\text { HVAC upgrade, and compressed air } \\
\text { system upgrade }\end{array}$ & $\$ 2.4 \mathrm{M}$ & $\$ 218,000$ per year \\
\hline USPS, Cluster 1, Royal Oak, MI & $\begin{array}{l}\text { Lighting retrofit, HVAC, system controls, } \\
\text { and chiller }\end{array}$ & $\$ 4.9 \mathrm{M}$ & TBD \\
\hline USPS, Cluster 2, Detroit, MI & $\begin{array}{l}\text { Lighting retrofit, HVAC, system controls, } \\
\text { and chiller }\end{array}$ & TBD & TBD \\
\hline USPS, Old Town, Alexandria, VA & $\begin{array}{l}\text { Lighting retrofit, HVAC, system controls, } \\
\text { and chiller }\end{array}$ & TBD & TBD \\
\hline $\begin{array}{l}\text { USPS, Metro District, Washington, } \\
\text { DC }\end{array}$ & $\begin{array}{l}\text { Lighting retrofit, HVAC, system controls, } \\
\text { and chiller }\end{array}$ & TBD & TBD \\
\hline USPS, Jamaica, NY & Lighting retrofit & $\$ 639,000$ & TBD \\
\hline $\begin{array}{l}\text { USPS, Bulk Mail Center, } \\
\text { Atlanta, GA }\end{array}$ & $\begin{array}{l}\text { Lighting retrofit, HVAC, system controls, } \\
\text { and chiller }\end{array}$ & $\$ 2.2 \mathrm{M}$ & TBD \\
\hline USPS, Island, Hawaii, HI & $\begin{array}{l}\text { Lighting retrofit, HVAC, system controls, } \\
\text { and chiller }\end{array}$ & TBD & TBD \\
\hline VA, Medical Center, Lake City, FL & Lighting retrofit & $\$ 280,288$ & None for 7 years \\
\hline VA, Medical Center, Dallas, TX & Thermal water storage & $\$ 1.4 \mathrm{M}$ & None for 6 years \\
\hline VA, Medical Center, Richmond, VA & Installation of cooling towers & $\$ 530,000$ & None for 6 years \\
\hline
\end{tabular}


May 21, 1997 saw the award of the first regional Super energy savings performance contract to: a joint venture of the Bentley Company/BMP Team, Puget Sound Energy, and MacDonald Miller Company; Energy Pacific (a joint venture of Enova and Pacific Enterprises); ERI Services; Johnson Controls; and Honeywell. These contractors will provide a wide range of energy savings services to Federal facilities in the Western Region of the U.S. (Alaska, Arizona, California, Hawaii, Idaho, Nevada, Oregon, Washington, and the U.S. Pacific Territories). The second was awarded on January 12, 1998 to: CES/Way International; Duke Engineering and Services; Energy Masters Corporation; ERI Services; Johnson Controls: and Honeywell. They will provide energy savings services to the Southeast Region of the U.S. (Alabama, Arkansas, Florida, Georgia, Kentucky, Mississippi, North Carolina, South Carolina, Tennessee, Puerto Rico and the U.S. Virgin Islands). The remaining four regional Super ESPCs (Midwest, Central/Rocky Mountain, Northeast, and Mid-Atlantic) will be awarded during FY 1998.

Regional Super ESPCs take the same general concepts as energy savings performance contracts but apply them on a much wider scale. The driving force behind this program is the desire to make the process of obtaining energy and cost savings much simpler for the individual agency.

Regional Super ESPCs share the same general contract terminology and provisions with the sitespecific ESPCs and the primary goal of both is to acquire private-sector funding for energy savings initiatives. Unlike conventional ESPCs the regional Super ESPCs will cover large geographical areas. The aim of this approach is to significantly reduce the lead time in the contracting process with ESCOs. Using delivery orders under a regional Super ESPC, agencies can contract to acquire retrofits and private-sector capital. It is anticipated that the time it takes to award a delivery order will be reduced to a period of around three months, a considerable step forward from the time delays a conventional ESPC can sometimes entail. Agencies will be further helped through the input of Department of Energy contracting and technical specialists. It is hoped that the implementation of the regional Super ESPCs will remove the majority of the procedural difficulties that agency managers have experienced.

The Western Region Super ESPC procurement required ESCOs to provide technical and cost proposals for projects at three agencies: the National Oceanic and Atmospheric Administration (NOAA), the Federal Aviation Administration (FAA), and the U.S. Coast Guard. The proposals from these projects will be the first delivery orders under the Western Super ESPC. NOAA's project at its Western Administrative Support Center at Sand Point in Seattle, Washington, includes lighting and heating, ventilation, and air-conditioning systems. FAA's project involves lighting, chillers, and motors at its Air Traffic Control Center in Auburn, Washington. The Coast Guard project is at the Integrated Support Center in Kodiak, Alaska. It includes lighting, an energy management system, replacement of doors and water heaters, and a boiler and controls upgrade.

An expansion of the technology specific Super ESPC program will also occur, starting in FY 1998. The first technology specific Super ESPC was awarded in September 1996 to Industrial Solar Technology (IST) Corporation to provide solar hot water heating via parabolic troughs. It is available on a sole-source basis to meet the needs of any Federal facility. Over 20 more contracts may be awarded to "buy energy savings" from specific technologies, including solar water heating, photovoltaics, or CFC-free chillers. 


\section{Utility Partnerships}

Although the availability of utility-sponsored demand side management programs is waning, Federal agency reports identified the receipt of at least $\$ 2.4$ million in incentive rebates in FY 1997. Utility incentive activities reported by the agencies occurred at installations widely distributed across the country. This decentralization of utility incentive participation makes it difficult for agencies to track all utility incentive activities undertaken by all respective subagencies, bureaus, and field offices. Total utility incentive benefits received by the Federal Government as a whole for FY 1997 are therefore assumed to be greater than reported.

Under incentive programs, utilities offer rebates to the customer which partially fund and help to promote the installation of new, more efficient equipment such as lighting systems, insulation, cooling equipment, and high efficiency motors. The customer, in this case the Federal Government, is then required to finance the remainder of the equipment cost. Utility incentive programs provide leverage for the user's investment dollars and at the same time help the utility to avoid the cost of building new power plants. EPACT and the Executive Order 12902 place heavy emphasis on utility incentive as a means for Federal agencies to achieve energy conservation.

The following agencies reported participation in demand side management programs in FY 1997:

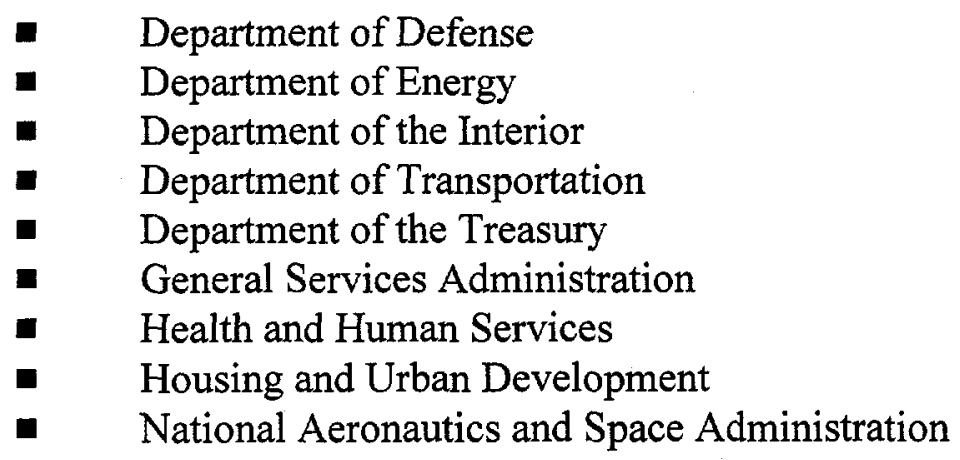

DOD has engaged in utility incentive programs in all four branches of the armed services. The Navy has utilized their partnership with San Diego Gas and Electric to retrofit nearly all Navy facilities in the greater San Diego area with the most life-cycle cost effective, energy efficient lighting systems. This $\$ 17$ million contract, partially funded by SDG\&E ( 30 percent), will save the Navy $\$ 2.5$ million annually. 


\section{F. Life-Cycle Costing (LCC)}

Section 544 of NECPA, as amended in 1988, requires DOE to establish practical and effective methods for estimating and comparing the life-cycle costs for Federal buildings using the sum of all capital and operating costs for energy systems of new buildings involved over the expected life of such systems or during a period of 25 years, whichever is shorter, and using average fuel costs and a discount rate determined by the Secretary of Energy. In addition, section 544 requires that procedures be developed in applying and implementing the methods that are established. EPACT further amends NECPA to require, after January 1, 1994, agencies which lease buildings to fully consider the efficiency of all potential building space at the time of renewing or entering into a new lease.

On November 20, 1990, DOE issued a Notice of Final Rulemaking to amend Title 10 of the Code of Federal Regulations, Part 436, which sets forth guidelines applicable to Federal agency in-house energy management programs. The principal regulatory changes involved amending the life-cycle cost methodology and procedures to provide for an annually determined, market-based discount rate and for a more effective system to revise annually the energy cost escalation rates that Federal agencies are required to assume. In developing the final amendments, the Department of Energy actively consulted with the Office of Management and Budget, the Department of Defense, and the General Services Administration.

In the past, DOE's Federal Energy Management Program has published updated fuel price projections for life-cycle cost analyses on October 1 of each year to coincide with the beginning of the fiscal year. The FY 1997 update of the Energy Price Indices and Discount Factors for Life Cycle Cost Analysis, Annual Supplement to Handbook 135 was published and distributed to Federal energy managers in July 1996 in order to bring the publication date closer to that of the price projections and energy analyses the Energy Information Administration publishes in their Annual Energy Outlook. In FY 1997, the official release date of the Annual Supplement for FY 1998 was changed from October 1, 1997 to April 1, 1997 and will remain April 1 in the future. The data within the Supplement is now applicable from April 1 through March 31. It is important to note that the life-cycle cost analysis data no longer runs concurrently with the Federal fiscal year or with the calendar year.

\section{G. Procurement Policy}

The Federal Government is the single largest purchaser of energy-related products and the largest user of energy in the U.S. Each year, the Federal Government purchases an estimated $\$ 10$ to $\$ 20$ billion in energy-related products. There is enormous potential for energy and dollar savings through procurement policies emphasizing energy efficiency. Such policies will not only reduce emission of green house gases, but will expand the market for efficient products, create a strong "market pull" for new technologies, and set a clear example for state and local governments and private industry.

Executive Order 12902, Energy Efficiency and Water Conservation at Federal Facilities," in conjunction with EPACT, established a clear mandate for agencies to use life-cycle cost analysis in their purchasing of energy-consuming equipment and to purchase "best practice" products 
whenever practicable and whenever they meet the agency's specific performance requirements and are cost-effective. Best practice products are those which are in the upper 25 percent of energy efficiency for all similar products, or products that are at least 10 percent more efficient than the minimum level that meets Federal standards.

Real or perceived barriers to energy-efficient purchasing also arise at the policy level. To ameliorate this situation, a Federal Acquisition Circular (FAC)-the medium for Federal Acquisition Regulation (FAR) amendments-was issued on August 22, 1997. The new regulation includes language on the acquisition of environmentally preferable and energyefficient products and services, defining "energy-efficient" in accordance with Executive Order 12902. The relevant section from 48 CFR, Part 23.704 states:

(a) Agencies shall implement cost-effective contracting preference programs favoring the acquisition of environmentally preferable and energy-efficient products and services.

(b) The following environmental objectives shall be addressed through the acquisition process:

(1) Obtaining products and services considered to be environmentally preferable (based on EPA-issued guidance).

(2) Obtaining products considered to be energy-efficient; i.e., products that are in the upper 25 percent of energy-efficiency for all similar products or products that are at least 10 percent more efficient than the minimum level that meets Federal standards (see E.O. 12902, Section 507).

DOE has also developed policy guidance for its own purchasing officers and program staff, including a section on energy-efficient purchasing in the DOE Acquisition Guide.

In FY 1997, DOE completed a feasibility study, currently undergoing internal review, that was produced in response to Section 152 of EPACT directing the Secretary of Energy to conduct a study to evaluate the potential use of the purchasing power of the Government to promote the development and commercialization of energy-efficient products. The study has two major parts: the first covers the process used in buying new products, the models in use, and how to do a new technology procurement, while the second part covers product selection, including a discussion of product characteristics with merit.

To assist Federal agencies in meeting the requirements of EPACT and E.O. 12902, the DOE Office of Federal Energy Management Program (FEMP), in cooperation with the Council on Environmental Quality and OMB's Office of Federal Procurement Policy, sponsored the Federal Procurement Challenge in September 1995. The heads of 22 Government agencies, representing almost 95 percent of the total Federal buying power, signed the Procurement Challenge committing themselves to purchasing energy- and water-saving products that will reduce their operating costs.

DOE FEMP provides Procurement Challenge participants with decision tools and technical support to help them achieve the Challenge goals. In 1997, FEMP produced and distributed eight 
additional product energy efficiency recommendations to be added to the one-stop shopping guide, Buying Energy Efficient Products, to help Federal purchasers identify products which meet the energy efficiency requirements of E.O. 12902. FEMP is planning to produce a ten minute video to support the guide. The video will introduce the energy efficiency directives of E.O. 12902, energy efficient procurement, and tools and resources available through FEMP.

The guide, which is also available on FEMP's Internet Web site at www.eren.doe.gov/femp, now includes 22 product energy efficiency recommendations. The guide also covers streamlined procurement, including a discussion of the Basic Ordering Agreement for CFC-free chillers, and will ultimately contain recommendations for 60 products. Categories covered range from fluorescent lighting to office equipment to commercial chillers. These recommendations will help agencies meet the goals of the Procurement Challenge by clearly defining the top 25 percent of efficiency for each product category, as well as illustrating the dollar savings that purchasers will realize from choosing products that meet the recommended levels instead of less efficient models. The first procurement training on Buying Energy Efficient Products was held in Washington, D.C., on March 7, 1997. A second training session was held on September 25, 1997 in Atlanta, Georgia.

To be most effective, the product efficiency recommendations must reach Federal buyers in a form they can use and be closely linked with other purchasing guidance, such as technical specifications and agency-specific policies and practices. Pursuant to this concern, FEMP has made considerable progress in partnership with the two major Government supply agencies, the General Services Administration and the Defense Logistics Agency. FEMP is working with GSA's Tools and Appliance Center in Fort Worth and with the Defense Logistics Agency (DLA) to identify energy efficient appliances in their supply system and code them with the energy efficient symbol ${ }_{\mathrm{E}}^{\mathrm{E}}$. Four appliances have been labeled so far. Cooperative efforts with GSA and DLA will extend use of the ${ }_{E}{ }_{E}$ symbol to other products in the Federal supply system, including on-line databases for electronic commerce. As a result of FEMP's coding efforts, customers shopping on-line can query for performance information.

Both DOD and GSA use the Federal Logistics Information System (FLIS) to procure products and equipment. FLIS catalogs millions of items by National Stock Numbers which can be accessed by vendor name or code. Currently the FAR requires only information on price, performance, and delivery schedule. DLA is trying to establish environmental segments and attributes within FLIS. DOD's Joint Logistics Commanders (JLC) support this initiative and have established the JLC Environmental Steering Committee. The Steering Committee will spearhead the development of an acquisition process to collect and rank information on environmental preferences, including energy efficiency, hazardous or toxic materials in the item or packaging, percent of recycled content, and biodegradability.

FEMP is working to expand the line of products available through Single Order Purchasing. The biggest success has been the chiller Basic Ordering Agreement (BOA). This innovative initiative was developed by the DOE Office of Defense Programs, FEMP, and the General Services Administration to streamline the procurement of large, energy-efficient, $\mathrm{CFC}$-free replacement chillers. Effective on November 15, 1996, the BOA allows Federal agencies to purchase chillers through the GSA Schedule by adopting a series of general specifications while permitting other 
important features to be individually specified. Five manufacturers have met the DOE general specifications and any chiller bought under this agreement complies with Executive Order 12902. The DOE Rocky Flats facility was the first site to use the BOA. The streamlined procurement takes 45 to 60 days, allowing customers to avoid the cumbersome bidding process previously required for chiller purchases. Cumulative energy cost savings are estimated at $\$ 1.4$ billion over the 20-year life of replacement chillers to be installed in Federal facilities. Agencies will also realize an estimated $\$ 600$ million in administrative cost savings and associated operation/maintenance services. This BOA will help "pull" the entire chiller market toward greater efficiency.

Coordination efforts with other buyer groups, utilities, and "market-pull" programs give FEMP's Procurement Challenge even greater leverage in meeting its energy saving, cost saving, and pollution prevention objectives. To help educate and inform government buyers at the State, local, and Federal levels on energy-efficient purchasing practices, DOE and EPA began the Energy Efficient Procurement Collaborative and the Energy Star Procurement Challenge. Its mission is to help educate and inform government buyers at the State, local, and Federal levels on energy-efficient purchasing practices, including on-line access to databases on efficient products and coordination of efficiency criteria and model specifications among public agencies. An important part of the strategy is to gain support at the top from such groups as the National Governors' Association and National Association of Counties.

Other FEMP outreach activities include the "You Have the Power" campaign to increase awareness of energy efficient procurement among Federal personnel. The Alliance to Save Energy, a non-profit, bipartisan group promoting energy efficiency currently chaired by Senator Jeff Bingaman, is developing a program with industry to promote the use of the energy efficient symbol, ${ }_{\mathrm{E}}^{\mathrm{E}}$

The Energy Efficiency Procurement Working Group announced that it will hold three interagency roundtable discussions in early November 1997 to obtain feedback on Federal procurement issues. The roundtables are intended to improve the Working Group's and FEMP's understanding of the Federal procurement process, to obtain feedback on existing program activities and information, and to solicit ideas on how to increase the program's effectiveness.

\section{H. Public Education Programs}

NECPA, 42 U.S.C. $\S 8258$ (b), requires the Secretary of Energy to include in this and subsequent annual reports information on public education programs carried out by Federal agencies and previously reported under the authority of section 381 of the Energy Policy and Conservation Act (EPCA), 42 U.S.C. $\S 6361(b)$.

EPCA requires the Secretary of Energy to establish and carry out public education programs to encourage energy conservation and energy efficiency and to promote vanpooling and carpooling arrangements. The Department of Transportation (DOT) has promoted ride sharing activities, while DOE has been responsible for other energy conservation education programs. 
Through its Federal Highway Administration, DOT obligates Federal aid funds to assist State and local agencies in implementing programs designed to encourage the use of car pools, van pools, and buses by commuters. DOT efforts have included van pool acquisition programs, fringe and corridor parking facilities, ride-matching projects, preferential treatments for high occupancy vehicles, and transit service improvement. Since 1974, over \$823.3 million in Federal-aid highway funds have been spent on such projects in an effort to establish self-sufficient programs across the Nation.

A series of reports based on joint research on Travel Demand Management (TDM) by the Federal Highway Administration and the Federal Transit Administration was published and distributed through the DOT Technology Sharing Program. "Implementing Effective Travel Demand Management Measures: Inventory of Measures and Synthesis of Experience," "Guidance Manual for Implementing Effective Employer-Based Travel Demand Management Programs," and "Overview of Travel Demand Management Measures" are three available reports. To obtain copies of these reports call 202-366-4208. A microcomputer analysis tool for the evaluation of TDM projects is also available through the University of Florida, Center for Microcomputers in Transportation, 512 Weil Hall, Gainesville, FL 32611-6585; telephone: 800-226-1013.

All of these reports and analysis tools are intended to provide technical assistance to individuals in the public and private sectors who are responsible for planning, implementing, operating, and/or monitoring TDM activities. They also are designed to educate these individuals on the state-of-the-practice and guide in the development of TDM programs.

The Department of Energy's public education programs encompass a wide variety of services, objectives, and audiences, covering all major areas of conservation and renewable energy. DOE has organized its technology transfer programs to meet the specific information requirements of various audiences.

The following four services are managed through subcontracts at the National Renewable Energy Laboratory (NREL). DOE's Energy Efficiency and Renewable Energy Clearinghouse (EREC). EREC provides basic, technical, and financial information on various energy efficiency/ renewable energy technologies and programs. The audience served by EREC includes the general public, business and industry, educational community, media, utility companies, and State and local governments. Information is provided in the form of fact sheets, DOE and National Laboratory books and brochures, bibliographies, and on-line computer-generated technology synopses. Some requests are handled completely over the phone and the caller receives no publications. EREC's telephone number is 800-DOE-EREC and its Web site is located at www.eren.doe.gov on the Internet. In 1997, EREC staff responded to 111,492 inquiries and disseminated 333,397 publications.

The Technical Information Program, operated by the National Renewable Energy Laboratory, provides information on energy efficiency and renewable energy to decision-makers at the Federal, State, and local levels as well as professionals in the buildings, industrial, utilities, and transportation sectors. TIP develops and produces communications products in support of EERE goals and technologies, including brochures, fact sheets, resource directories, videos, exhibits, and compilations of photos and documents. 
The Office of Federal Energy Management Programs (FEMP) Help Desk provides Federal energy managers with specialized information on effective energy management practices, technical assistance on implementing Federal sector energy projects, financing information, energy modeling software, publications, and energy management training programs. The primary goal of this service is to assist Federal agencies in meeting various legislative requirements. The Help Desk responds to requests for information via a toll-free automated telephone service, electronic mail, and through the Internet. The Help Desk was merged into EREC in FY 1997. The telephone number is $800-363-3732$.

The National Energy Information Center (NEIC) responds to public and private sector questions on energy production, consumption, prices, resource availability, and projections of supply and demand. It also makes available the publications, and data tapes produced by the DOE Energy Information Administration. NEIC provides information to Federal employees and the public through an on-line bulletin board service 202-586-2557 and at http://www.eia.doe.gov on the Internet. Electronic inquiries may be sent to infoctr@eia.doe.gov on the Internet. In 1997, NEIC staff responded to 30,331 inquiries and distributed approximately 34,538 publications.

The Office of Scientific and Technical Information (OSTI), as part of the Office of Energy Research, provides coordination and direction for the management of scientific and technical information resulting from the DOE's multi-billion dollar research and development activities. As a cross-cutting Headquarters office, OSTI accomplishes its mission through the Scientific and Technical Information Program (STIP). STIP operates in partnership with Program offices, operations offices, and contractor elements to develop and implement information management "best business practices" to ensure that DOE maximizes the return on its $\$ 6$ billion annual R\&D investment.

In support of national competitiveness, OSTI collects, processes, and disseminates DOEoriginated research information and selected worldwide research literature on subjects of interest to domestic communities. OSTI also provides scientific and technical information services to, or on behalf of, DOE elements in support of Departmental mandates, missions, and objectives. OSTI serves the public directly or indirectly through agreements with the National Technical Information Service, Government Printing Office, depository libraries, and commercial vendors. In 1997 OSTI unveiled EnergyFiles, a publicly available, web-based gateway to a wide array of energy-related information. Included among the EnergyFiles family is the DOE Information Bridge, an electronic full-text collection of 23,000 documents available to the DOE research community. DOE Information Bridge will be made publicly available sometime in 1998.

OSTI manages a comprehensive collection of approximately one million scientific and technical information documents, representing 50 years of energy-related activities. The organization also maintains the Energy Science and Technology Database (EDB), which has over 3.5 million summaries of DOE and worldwide information. EDB is made available to the public on-line and on CD-ROM through commercial vendors. The majority of its users are industry, Federal and State officials, contractors, libraries, research institutions, and the public. In FY 1997, OSTI added over 158,000 research summaries to the database and provided 16,000 full-text documents for public availability to the National Technical Information Service and the Government Printing Office Depository Library Program. 
FY 1997 initiatives included a strategic effort to process and disseminate information in an increasingly decentralized environment. As a continuing step towards a "National Library of Energy Science and Technology," the effort will significantly improve DOE and public access to bibliographic and full-text information without major additional investment. In addition to the core program activities, OSTI's other services include developing Internet-based applications for DOE offices, providing information management advice and consultation to the Departmental community, managing and disseminating DOE and Nuclear Regulatory Commission scientific and technical software, and representing the United States in multilateral and bilateral international information exchange agreements.

The DOE public information mechanisms include several direct service programs designed to provide technical assistance to specific target groups. Some of these include:

- The State Energy Program, a consolidated grant program which includes the former Institutional Conservation Program, provides a flexible, supportive framework to enable the States to address their own energy priorities as well as focus on national initiatives and strengthens their capabilities to deliver energy services. This customer-driven program seeks to increase the extent to which Federal, State, and local governments work with other public and private sector entities to achieve widespread adoption of available energy efficiency and renewable energy technologies, and to demonstrate the use of emerging technologies which benefit the entire economy. This also includes working with the building industry and consumers for improvements in residential energy efficiency.

- The Industrial Assessment Center Program (IAC) provides no-charge energy, waste, and productivity assessments to help small and mid-sized manufacturers identify measures and plant and office designs to maximize energy-efficiency, reduce waste, and improve productivity. The analyses are performed by local teams of engineering faculty and students from 30 participating universities across the country.

A full list of DOE's energy education, extension, and information services is Appendix E to this report. 


\section{ENERGY MANAGEMENT IN BUILDINGS AND FACILITIES}

\section{A. Energy Consumption and Costs for Buildings and Facilities}

The Federal Government provides energy to approximately 500,000 buildings and facilities comprising approximately 3.0 billion square feet of floor area. This energy is used to provide lighting, heating, ventilation, air conditioning, and other standard building services, as well as a significant amount of process operations that are not reported separately. ${ }^{11}$ Federal buildings include both Federally-owned and leased buildings. However, in many instances the lessor pays the energy bill, and consumption and cost data may not be available to the Government. Accordingly, Federal agencies report data for leased space to the maximum extent practicable. ${ }^{12}$

Table 4-A shows the total primary energy consumed in Federal buildings and facilities, including energy resources used to generate, process, and transport electricity and steam. ${ }^{13}$ Primary energy consumed in buildings and facilities in FY 1997 decreased 14.0 percent from FY 1985 and 2.3 percent from FY 1996.

Table 4-B shows that agencies have decreased net energy consumption in buildings by 25.7 percent, from 471.6 trillion Btu in FY 1985 to 350.3 trillion Btu in FY 1997. A comparison to FY 1996 shows a decrease of 3.9 percent in total buildings energy consumption.

Of the 28 agencies represented on the tables for FY 1997, 11, including DOD, consume over 98 percent of the reported buildings energy use. Energy used in buildings accounts for approximately 32.4 percent of the total 1.08 quads used by the Federal Government. The mix of Federal buildings energy use for Defense and civilian agencies is depicted in Figure 5. Electricity constitutes 41.6 percent (145.9 trillion Btu) of Federal buildings energy use; 36.1 percent is accounted for by natural gas

\section{FIGURE 5}

Defense and Civilian Energy Consumption in Buildings and Facilities by Fuel Type, FY 1997

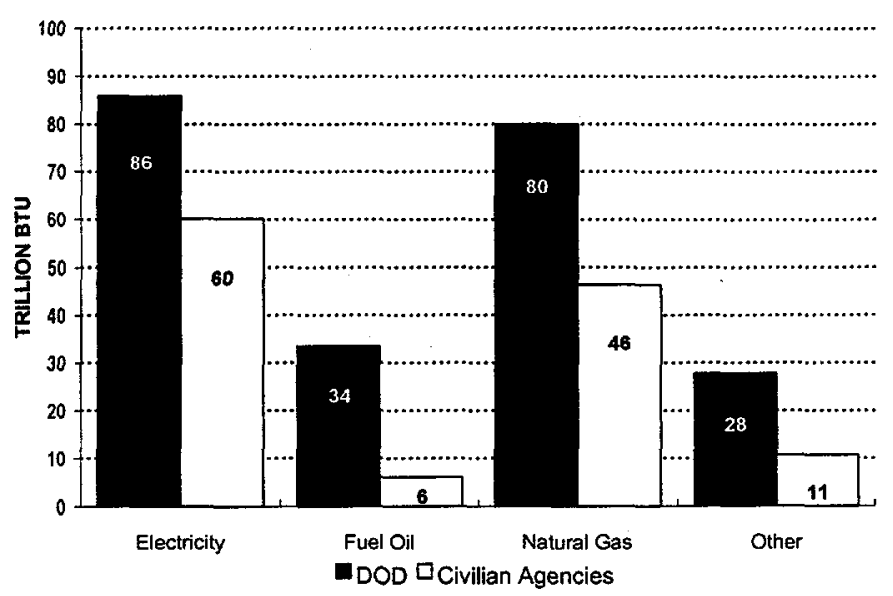

\footnotetext{
${ }^{11}$ Process energy is that energy used in buildings for operations other than standard building services. In cases where separate reporting was not possible, due to the lack of meters or estimation techniques, process energy was reported as though it was part of the energy used for standard building services.

${ }^{12}$ The General Services Administration (GSA) is the primary leasing agent for the Federal Government, although most of the other agencies do have some leasing authority. In some cases, GSA will delegate operations and maintenance responsibility to individual agencies for leased space, requiring the agency to be responsible for paying the utility bills and reporting energy consumption.
}

\footnotetext{
${ }^{13}$ Source conversion factors of 11,600 Btu per kilowatt hour for electricity and 1,390 Btu per pound of steam are used to calculate primary energy consumption. See Appendix B for conversion factors for net energy consumption.
} 
TABLE 4-A

FEDERAL PRIMARY ENERGY CONSUMPTION IN BUILDINGS AND FACILITIES

(In Billions of Btu, with Conversions to Millions of Barrels of Oil Equivalent [MBOE], and Petajoules [Joule $\times 10^{15}$ ])

\begin{tabular}{|c|c|c|c|c|c|c|c|c|c|c|c|c|c|c|}
\hline $\begin{array}{l}\text { CIVILIAN } \\
\text { AGENCY }\end{array}$ & $\begin{array}{l}\text { FY } \\
1985\end{array}$ & $\begin{array}{c}F Y \\
1986\end{array}$ & $\begin{array}{c}F Y \\
1987\end{array}$ & $\begin{array}{c}F Y \\
1988\end{array}$ & $\begin{array}{c}\text { FY } \\
1989\end{array}$ & $\begin{array}{c}\text { FY } \\
1990\end{array}$ & $\begin{array}{c}F Y \\
1991\end{array}$ & $\begin{array}{c}F Y \\
1992\end{array}$ & $\begin{array}{c}\mathrm{FY} \\
1993\end{array}$ & $\begin{array}{c}F Y \\
1994\end{array}$ & $\begin{array}{c}\text { FY } \\
1995\end{array}$ & $\begin{array}{c}\text { FY } \\
1996\end{array}$ & $\begin{array}{c}\text { FY } \\
1997\end{array}$ & $\begin{array}{c}\% \text { Change } \\
85-97\end{array}$ \\
\hline USPS & $39,441.0$ & $39,869.0$ & $41,604.2$ & $43,801.4$ & $45,783.8$ & $46,961.6$ & $48,347.0$ & $50,147.1$ & $54,073.7$ & $55,445.6$ & $56,551.3$ & $58,757.3$ & $53,728.0$ & 36.2 \\
\hline DOE & $57,430.1$ & $55,887.9$ & $55,086.1$ & $56,902.3$ & $54,218.3$ & $54,839.0$ & $52,941.5$ & $56,282.4$ & $57,050.7$ & $55,100.0$ & $53,654.4$ & $53,930.0$ & $51,709.7$ & -10.0 \\
\hline VA & $42,333.7$ & $41,539.9$ & $41,703.6$ & $44,208.4$ & $44,638.1$ & $43,818.9$ & $44,954.2$ & $44,759.7$ & $45,620.4$ & $46,265.4$ & $46,823.0$ & $48,062.3$ & $48,419.3$ & 14.4 \\
\hline GSA & $41,207.0$ & $33,948.9$ & $32,264.2$ & $30,314.2$ & $30,916.4$ & $35,985.0$ & $34,685.4$ & $34,300.3$ & $34,198.2$ & $33,661,4$ & $32,912.4$ & $34,286.0$ & $34,492.7$ & -16.3 \\
\hline DOJ & $8,962.7$ & $9,539.8$ & $9,290.5$ & $11,160.0$ & $9,929.5$ & $9,376.1$ & $12,038.8$ & $9,285.9$ & $11,999.4$ & $11,390.0$ & $11,836.6$ & $14,391.8$ & $14,681.7$ & 63.8 \\
\hline HHS & $12,605.4$ & $10,322.4$ & $10,869.2$ & $11,930.4$ & $12,676.1$ & $16,191.3$ & $14,353.7$ & $15,857.0$ & $16,086.8$ & $16,320.7$ & $11,904.8$ & $12,623.5$ & $14,320.3$ & 13.6 \\
\hline NASA & $6,373.5$ & $6,710.6$ & $6,875.1$ & $6,995.9$ & $7,305.3$ & $7,363.2$ & $7,388.3$ & $7,151.6$ & $7,056.1$ & $7,299.4$ & $7,854.2$ & $8,571.6$ & $9,857.0$ & 54.7 \\
\hline DOT & $8,298.7$ & $8,694.0$ & $7,377.3$ & $7,315.5$ & $6,692.7$ & $7,114.8$ & $6,609.9$ & $8,355.1$ & $8,687.6$ & $8,427,4$ & $9,020.4$ & $9,097.4$ & $9,378.3$ & 13.0 \\
\hline $\mathrm{DOI}$ & $8,432.5$ & $6,849.9$ & $6,692.3$ & $.7,366.5$ & $7,745.0$ & $7,511.8$ & $7,746.9$ & $6,824.4$ & $8,320.8$ & $8,186.2$ & $7,646.7$ & $6,177.5$ & $7,024.2$ & -16.7 \\
\hline TRSY & $1,451.0$ & $1,423.9$ & $3,488.5$ & $6,691.5$ & $5,656.9$ & $5,004.1$ & $4,372.2$ & $4,805.4$ & $4,250.4$ & $4,351.0$ & $3,752.5$ & $3,607.0$ & $4,802.7$ & 231.0 \\
\hline USDA & $4,347.2$ & $4,210.0$ & $4,734.5$ & $4,366.4$ & $4,399.9$ & $5,397.9$ & $5,604.9$ & $5,339.6$ & $5,477.6$ & $5,253.7$ & $5,118.6$ & $5,280.2$ & $4,701.3$ & 8.1 \\
\hline $\mathrm{DOL}$ & $3,687.8$ & 3.751 .7 & $3,785.1$ & 3.914 .9 & $3,880.5$ & $3,864.3$ & $3,784.8$ & $3,821.2$ & $3,955.1$ & $4,033.6$ & $3,922.1$ & $4,043.4$ & $4,079.0$ & 10.6 \\
\hline TVA & $1,321.0$ & $1,526.2$ & $1,551.2$ & $1,500.1$ & $1,383.8$ & $1,410.5$ & $1,423.4$ & $1,422.0$ & $1,465.1$ & $2,228.3$ & $2,465.3$ & $2,387.9$ & $2,250.3$ & 70.3 \\
\hline EPA & $1,618.3$ & $1,539.7$ & $1,465.9$ & $1,565.4$ & $1,558.7$ & $1,616.4$ & $1,782.6$ & $1,811.6$ & $1,898.2$ & $1,984.3$ & $2,131.8$ & $2,096.3$ & $2,075.0$ & 28.2 \\
\hline DOC & $1,189.1$ & $2,571.4$ & $2,485.7$ & $2,683.6$ & $3,062.9$ & $3,227.4$ & $3,220.7$ & 1483.1 & 1.664 .7 & $2,047.3$ & $1,361.7$ & $1,313.7$ & $1,303.3$ & 9.6 \\
\hline ST & 689.2 & 724.5 & 803.1 & 781.1 & 796.4 & 817.3 & 845.4 & 829.4 & 133.4 & 235.6 & 255.3 & 780.5 & 968.1 & 40.5 \\
\hline HUD & 349.3 & 350.1 & 355.7 & 373.0 & 417.0 & 426.5 & 417.0 & 384.1 & 348.6 & 323.7 & 316.1 & 332.9 & 320.6 & -8.2 \\
\hline PCC & 90.5 & 90.8 & 92.4 & 96.6 & 95.8 & 97.2 & 110.2 & 102.3 & 110.5 & 106.8 & 108.6 & 110.3 & 115.3 & 27.3 \\
\hline FCC & 29.5 & 31.9 & 34.5 & 35.2 & 32.4 & 41.0 & 43.7 & 33.9 & 35.1 & 39.4 & 39.4 & 31.7 & 31.7 & 7.2 \\
\hline OTHER* & 947.5 & $1,257.2$ & $1,426.1$ & $1,549.7$ & $1,757.2$ & $1,747.8$ & $1,281.1$ & $1,273.7$ & $1,035.2$ & $1,023.3$ & $3,054.3$ & $5,026.6$ & $5,292.9$ & 458.6 \\
\hline \multicolumn{15}{|c|}{ CIVILIAN AGENCIES } \\
\hline TOTAL & $240,805.2$ & $230,839.8$ & $231,985.4$ & $243,552.1$ & $242,946.3$ & $252,812.0$ & $251,951.8$ & $254,269.7$ & $263,467.8$ & $263,723.0$ & $260,729.6$ & $270,907.9$ & $269,551.3$ & 11.9 \\
\hline DOD & $581,170.2$ & $552,598.8$ & $595,765.7$ & $546,127.6$ & $576,994.6$ & $580,184.6$ & $523,370.8$ & $524,164.8$ & $523,295.3$ & $502,215.0$ & $476,188.2$ & $452,388.4$ & $436,940.7$ & -24.8 \\
\hline \multicolumn{15}{|c|}{ ALL AGENCIES } \\
\hline TOTAL & $821,975.4$ & $783,438.6$ & $827,751.1$ & $789,679.6$ & $819,941.0$ & $832,996.6$ & $775,322.5$ & $778,434.5$ & $786,763.0$ & $765,938.1$ & $736,917.7$ & $723,296.4$ & $706,492.1$ & -14.0 \\
\hline MBOE & 141.1 & 134.5 & 142.1 & 135.6 & 140.8 & 143.0 & 133.1 & 133.6 & 135.1 & 131.5 & 126.5 & 124.2 & 121.3 & \\
\hline Petajoules & 867.2 & 826.5 & 873.2 & 833.1 & 865.0 & 878.8 & 817.9 & 821.2 & 830.0 & 808.0 & 777.4 & 763.1 & 745.3 & \\
\hline
\end{tabular}

*Other includes for certain years the CFTC, CIA, EEOC, FEMA, FTC, NARA, NSF, NRC, OPM, RRB, SSA, USIA, and FERC.

Note: This table uses a conversion factor for electricity of 11,600 Btu per kilowatt hour and 1,390 Btu per pound of steam. Agencies are listed in descending order of consumption for the current year. Sum of components may not equal total due to independent rounding.

Source: Federal Agency Annual Energy Management Data Reports 
TABLE 4-B

FEDERAL NET ENERGY CONSUMPTION IN BUILDINGS AND FACILITIES

(In Billions of Btu, with Conversions to Millions of Barrels of Oil Equivalent [MBOE], and Petajoules [Joule x 10 ${ }^{15}$ ])

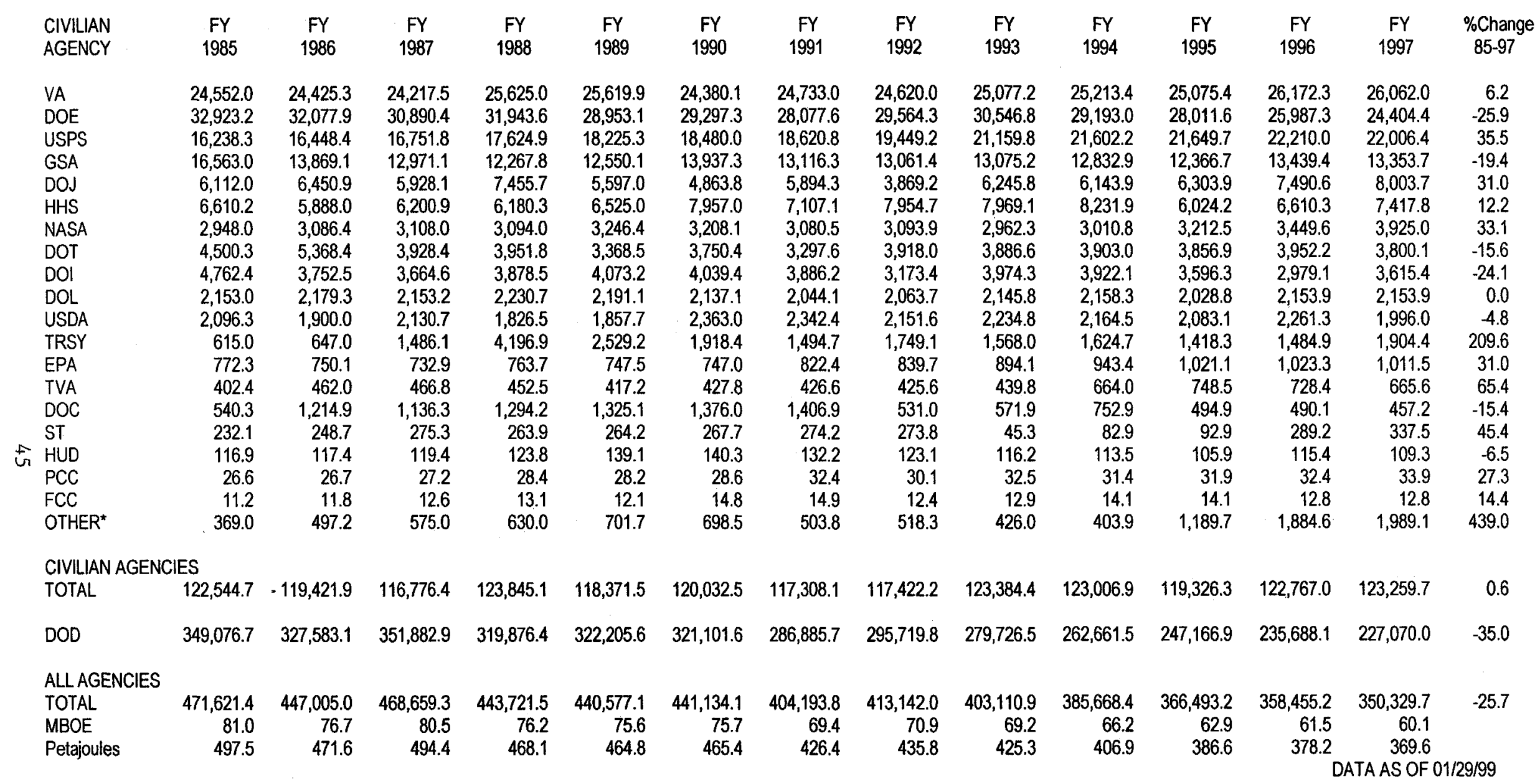

*Other includes for certain years the CFTC, CIA, EEOC, FEMA, FTC, NARA, NSF, NRC, OPM, RRB, SSA, USIA, and FERC.

Note: This table uses a conversion factor for electricity of 3,412 Btu per kilowatt hour. Agencies are listed in descending order of consumption for the current year.

Sum of components may not equal total due to independent rounding.

Source: Federal Agency Annual Energy Management Data Reports 
(126.4 trillion Btu), and 11.3 percent by fuel oil (39.6 trillion Btu). Coal, purchased steam, liquefied petroleum gas (LPG)/propane, and energy reported as "other" (comprised mainly of chilled water and renewable energy), account for the remaining 11.0 percent.

Figure 6 illustrates the proportion of energy consumption in buildings and facilities that is attributable to electricity for FY 1985 through FY 1997. The figure also breaks out the amount of Btu lost through the generation and transmission processes and amount of Btu delivered to the site. In FY 1997, electricity consumption, including energy used at the source of generation, accounted for approximately 70.2 percent of the total primary Btu consumed in buildings and facilities (706,492.1 billion Btu; see Table 4-A). Of this amount, approximately 29.4 percent or 145.9 trillion Btu reached the site of use. The remaining 70.6 percent, 350.0 trillion Btu, was lost during the generation and transmission processes.

\section{FIGURE 6 \\ Consumption of Electricity and Other Fuels in Buildings and Facilities, FY 1985 through FY 1997}

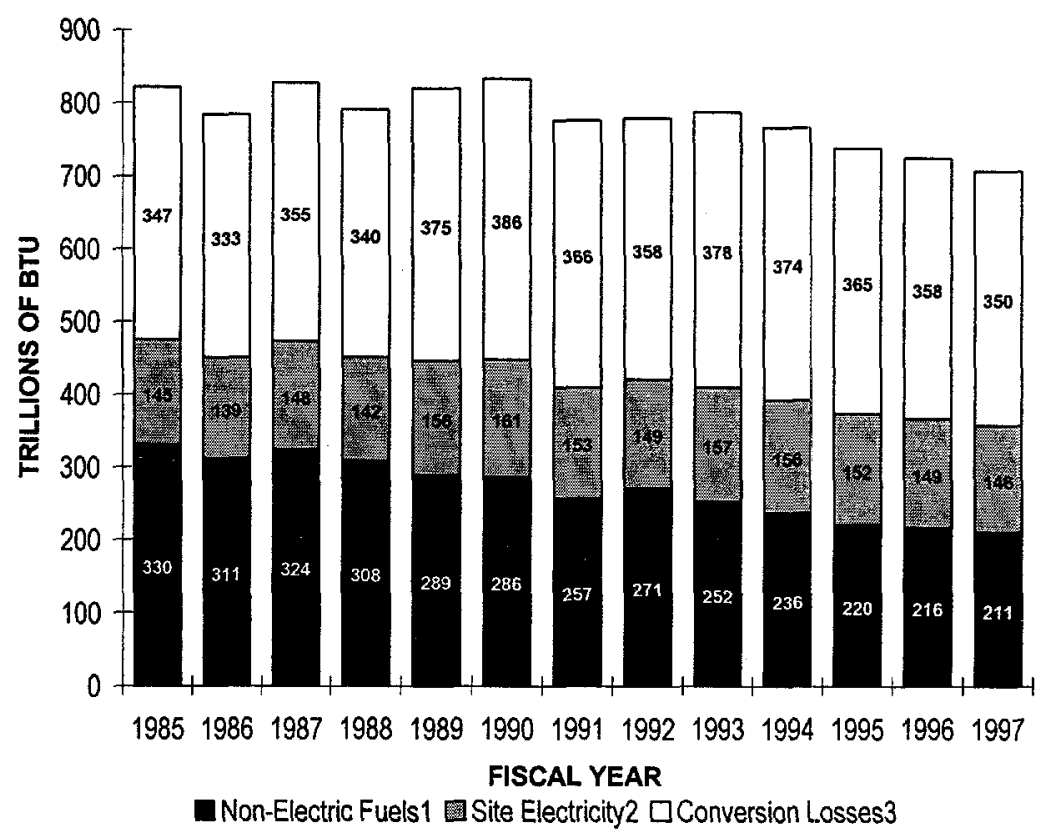

'Includes Fuel Oil, Natural Gas, LPG/Propane, Coal, Purchased Steam, and Other. Uses a conversion factor for steam of 1,390 Btu per pound (source conversion).

${ }^{2}$ Uses a conversion factor of 3,412 Btu per kilowatt hour. Amount of energy which reaches the site of use when generation and transmission losses are subtracted.

${ }^{3}$ Amount of energy lost through generation and transmission processes. When added to amount of energy reaching the point of use, the total equals amount of Btu consumed at the source. The source conversion factor is 11,600 Btu per kilowatt hour.

Source: Federal Agency Annual Energy Management Data Reports 
Decreases in consumption relative to FY 1996 were seen in fuel oil (19.8 percent), LPG/propane (13.7 percent), purchased steam (10.0 percent), and electricity ( 2.2 percent). Increases from the previous year were seen in natural gas ( 4.1 percent), coal (3.8 percent), and fuels reported under the category of "other" (768.5 percent). "Other" fuels comprise only 0.4 percent of buildings and facilities energy.

The mix of fuels consumed by Government buildings has changed notably from FY 1985 through FY 1997. The actual consumption of electricity has remained constant since FY 1985, with an increase of 0.8 percent in FY 1997 while square footage has declined 11.2 percent. However, the proportion of energy consumed in Federal buildings and facilities that is electricity has increased from 30.7 percent in FY 1985 to 41.6 percent in FY 1997. Over the same period, fuel oil use decreased from 22.8 percent of the total in FY 1985 to only 11.3 percent in FY 1997. The portion of the Federal buildings fuel mix comprised by natural gas has increased from 30.7 percent in FY 1985 to 36.1 percent in FY 1997. The use of coal as a fuel source, which accounted for 12.3 percent of the total energy consumed in FY 1985, has declined to 5.4 percent of the total in FY 1997. Contributing to this has been the practice of agencies, such as DOE, to purchase steam rather than generating their own in coal-fired plants.

As shown in Table 5, the consumption of petroleum-based fuels in buildings during FY 1997 decreased 62.2 percent compared to FY 1985 and 19.4 percent from FY 1996. Efforts by agencies to utilize natural gas as a cost-effective substitute for petroleum-based fuels in buildings as well as conservation of fuel oil and LPG/propane in buildings contributed to these reductions. Petroleum fuel consumption in buildings during FY 1997 represented only 12.0 percent of all energy consumed in Federal buildings. Of this amount, 94.3 percent is attributed to fuel oil and the remaining 5.7 percent to $\mathrm{LPG} /$ propane.

The energy used in buildings in FY 1997 accounted for approximately 43.1 percent of the total Federal energy bill. Tables 6-A and 6-B show that the Federal Government spent approximately $\$ 3,560.0$ million for buildings energy during the fiscal year, a decrease in constant dollars of approximately $\$ 145.7$ million from FY 1996 expenditures. The combined cost of buildings energy in FY 1997 was $\$ 10.16$ per million Btu, down 1.7 percent from the combined cost of $\$ 10.34$ reported in FY 1996.

FIGURE 7

Energy Costs (Constant 1997 Dollars) in Buildings and Facilities, FY 1985 through FY 1997

Figure 7 illustrates energy expenditures for buildings and facilities from FY 1985 through FY 1997. In constant 1997 dollars, Federal energy costs for buildings and facilities decreased 37.8 percent from $\$ 5,723.1$ million in FY 1985 to $\$ 3,560.0$ million in FY 1997 . The combined cost for buildings energy in constant dollars in FY 1997 was $\$ 10.16$ per million Btu, down 16.2 percent from $\$ 12.14$ per million Btu in FY 1985.

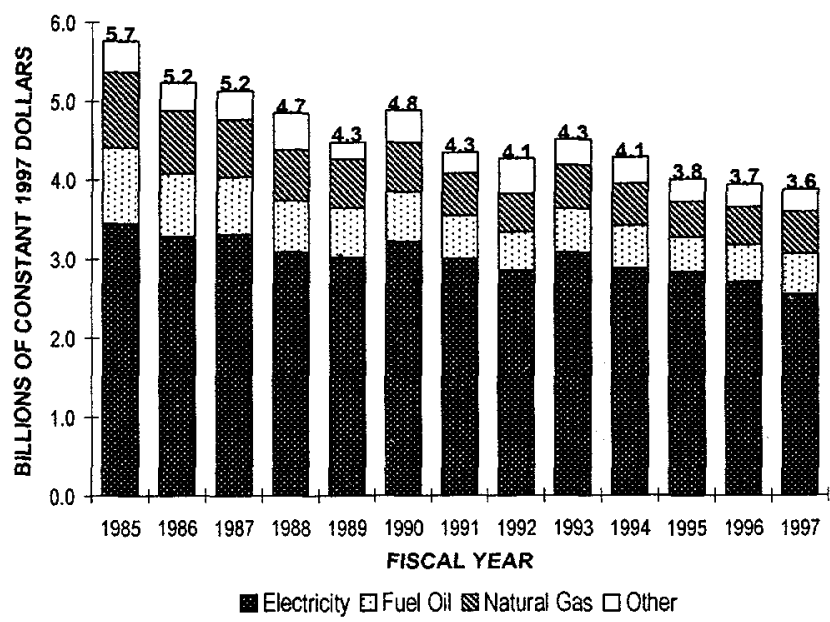

47 
TABLE 5

PETROLEUM-BASED FUEL* CONSUMPTION IN BUILDINGS AND FACILITIES

(In Billions of Btu)

\begin{tabular}{|c|c|c|c|c|c|c|c|c|c|c|c|c|c|c|}
\hline AGENCY & $\begin{array}{l}\text { FY } \\
1985\end{array}$ & $\begin{array}{c}\text { FY } \\
1986\end{array}$ & $\begin{array}{c}\text { FY } \\
1987\end{array}$ & $\begin{array}{c}\text { FY } \\
1988\end{array}$ & $\begin{array}{c}\text { FY } \\
1989\end{array}$ & $\begin{array}{c}\text { FY } \\
1990\end{array}$ & $\begin{array}{c}\text { FY } \\
1991\end{array}$ & $\begin{array}{c}\text { FY } \\
1992\end{array}$ & $\begin{array}{c}\text { FY } \\
1993\end{array}$ & $\begin{array}{c}\mathrm{FY} \\
1994\end{array}$ & $\begin{array}{c}\text { FY } \\
1995\end{array}$ & $\begin{array}{c}\text { FY } \\
1996\end{array}$ & $\begin{array}{r}F Y \\
1997\end{array}$ & $\begin{array}{c}\text { \%CHANGE } \\
85-97\end{array}$ \\
\hline DOD & $96,817.3$ & $85,607.3$ & $90,403.2$ & $78,345.1$ & $70,701.8$ & $69,030.1$ & $59,451.5$ & $65,654.1$ & $55,585.9$ & $50,285.7$ & $42,939.0$ & $42,861.7$ & $35,214.4$ & -63.6 \\
\hline DOE & $1,650.8$ & $1,315.4$ & $1,530.2$ & $1,563.5$ & $1,729.0$ & $1,900.5$ & $2,063.7$ & $2,042.7$ & $1,943.5$ & $1,924.4$ & $1,973.5$ & $1,554.1$ & $1,398.9$ & -15.3 \\
\hline VA & $2,176.7$ & $2,118.5$ & $2,261.3$ & $2,488.2$ & $2,328.8$ & $2,219.3$ & $1,404.9$ & $1,506.0$ & $1,533.9$ & $1,827.4$ & $1,292.9$ & $2,098.2$ & $1,186.3$ & -45.5 \\
\hline USPS & $1,673.2$ & $1,591.6$ & $1,556.3$ & $1,602.6$ & $1,555.7$ & $1,502.2$ & $1,219.4$ & $1,195.8$ & 988.8 & 983.7 & 813.9 & 595.2 & 819.0 & -51.1 \\
\hline $\mathrm{DOI}$ & $1,591.6$ & $1,430.7$ & $1,272.1$ & $1,364.7$ & $1,376.7$ & $1,273.9$ & $1,141.1$ & 919.1 & $1,181.9$ & $1,560.6$ & $1,574.3$ & $1,177.7$ & 799.6 & -49.8 \\
\hline HHS & $2,199.6$ & $2,680.8$ & $2,643.8$ & $2,008.1$ & $2,059.8$ & $2,138.7$ & $1,545.9$ & $2,144.2$ & $1,765.2$ & $1,525.7$ & $1,152.5$ & $1,718.8$ & 760.7 & -65.4 \\
\hline DOT & $2,376.9$ & $3,564.0$ & $2,107.2$ & $2,100.0$ & $1,534.8$ & $1,524.1$ & $1,308.4$ & $1,426.0$ & 854.0 & $1,001.6$ & 911.7 & 709.2 & 670.5 & -71.8 \\
\hline USDA & 414.2 & 260.7 & 191.0 & 206.4 & 229.1 & 260.0 & 291.3 & 242.9 & 255.6 & 236.3 & 244.1 & 242.5 & 272.2 & -34.3 \\
\hline $\mathrm{DOL}$ & 437.8 & 414.5 & 427.0 & 387.3 & 394.5 & 331.2 & 258.3 & 263.6 & 276.1 & 277.5 & 210.8 & 220.6 & 254.2 & -41.9 \\
\hline GSA & 991.3 & 667.8 & 530.3 & 561.8 & 544.0 & 668.1 & 443.1 & 418.2 & 359.4 & 379.8 & 199.0 & 242.3 & 143.0 & -85.6 \\
\hline DOJ & 381.7 & 363.4 & 467.3 & 970.3 & 310.8 & 371.6 & 503.7 & 383.8 & 250.8 & 234.8 & 182.8 & 234.3 & 134.9 & -64.6 \\
\hline NASA & 230.2 & 233.2 & 262.0 & 253.1 & 291.2 & 277.8 & 161.6 & 217.6 & 134.5 & 139.6 & 88.6 & 110.9 & 93.2 & -59.5 \\
\hline ClA & 0.0 & 0.0 & 0.0 & 0.0 & 0.0 & 0.0 & 0.0 & 0.0 & 0.0 & 0.0 & 49.6 & 87.9 & 84.6 & $N / A$ \\
\hline TRSY & 22.5 & 25.4 & 172.9 & 294.2 & 319.3 & 281.3 & 127.7 & 84.2 & 190.5 & 160.8 & 116.6 & 116.2 & 57.0 & 153.9 \\
\hline EPA & 16.8 & 15.8 & 14.6 & 12.4 & 14.3 & 5.9 & 6.4 & 17.6 & 13.9 & 26.8 & 43.4 & 51.8 & 26.1 & 55.6 \\
\hline ST & 0.0 & 0.0 & 0.0 & 0.0 & 0.0 & 0.0 & 0.0 & 0.0 & 0.0 & 0.0 & 0.0 & 21.8 & 21.2 & N/A \\
\hline $\mathrm{DOC}$ & 130.3 & 95.5 & 78.9 & 85.1 & 36.8 & 77.6 & 13.1 & 9.8 & 23.8 & 52.4 & 10.8 & 33.4 & 9.3 & -92.8 \\
\hline FCC & 1.7 & 1.6 & 1.4 & 1.7 & 1.5 & 1.9 & 1.0 & 1.3 & 1.3 & 1.3 & 1.3 & 1.7 & 1.7 & 0.8 \\
\hline TVA & 4.2 & 2.9 & 1.6 & 3.0 & 1.2 & 3.2 & 0.1 & 1.3 & 2.7 & 3.5 & 3.9 & 4.1 & 0.0 & -100.0 \\
\hline OTHER ${ }^{* *}$ & 76.1 & 85.1 & 82.7 & 86.5 & 89.6 & 83.7 & 59.1 & 67.2 & 67.6 & 49.1 & 49.1 & 57.3 & 60.9 & -20.0 \\
\hline TOTAL & $111,193.0$ & $100,474.3$ & $104,003.9$ & $92,334.1$ & $83,519.0$ & $81,951.0$ & $70,000.2$ & $76,595.5$ & $65,429.4$ & $60,671.0$ & $51,857.6$ & $52,139.7$ & $42,007.9$ & -62.2 \\
\hline
\end{tabular}

DATA AS OF 01/29/99

*Petroleum-based fuels include fuel oil and LPG/propane.

**Other includes for certain years EEOC, FEMA, NSF, SSA, and USIA

Note: FY 1996 contains estimated data for the following agencies: FEMA, FTC, and OPM.

Sum of components may not equal total due to independent rounding.

Source: Federal Agency Annual Energy Management Data Reports 
TABLE 6-A

DEFENSE AND CIVILIAN FEDERAL COSTS FOR BUILDINGS ENERGY IN FY 1997

(In Millions of Dollars)

$\begin{array}{lcrrrrrrr} & \text { ELECTRICITY } & \text { FUEL OIL } & \begin{array}{c}\text { NATURAL } \\ \text { GAS }\end{array} & \begin{array}{c}\text { LPG/ } \\ \text { PROPANE }\end{array} & \text { COAL } & \begin{array}{c}\text { PURCHASED } \\ \text { STEAM }\end{array} & \text { OTHER } & \text { TOTAL } \\ \text { DEFENSE } & 1,467.868 & 162.963 & 317.292 & 15.459 & 34.336 & 159.713 & 0.748 & 2,158.379 \\ \text { CIVILIAN } & 1,091.887 & 34.438 & 202.298 & 6.693 & 6.261 & 52.966 & 7.040 & 1,401.583 \\ \text { TOTAL } & 2,559.755 & 197.401 & 519.590 & 22.152 & 40.597 & 212.679 & 7.788 & 3,559.962\end{array}$

AVERAGE COST PER UNIT, BASED ON REPORTS FROM AGENCIES

$\begin{array}{llrl}\text { ELECTRICITY } & =59.88, \text { MWH } \\ \text { FUEL OIL } & =0.69, \text { GALLON } \\ \text { NATURAL GAS } & =4.24, \text { THOUSAND CUBIC FEET } \\ \text { LPG/PROPANE } & =0.88, \text { GALLON } \\ \text { COAL } & =52.87, \text { SHORT TON } \\ \text { PURCHASED } & & \\ \text { STEAM } & =13.56, \text { MLLLION BTU } \\ \text { OTHER } & =5.16, \text { MILLION BTU }\end{array}$

DATA AS OF 01/29/99

Note: Contains estimated data for the following agencies: FEMA, FCC, FTC, and OPM.

Sum of components may not equal total due to independent rounding.

Source: Federal Agency Annual Energy Management Data Reports. 
TABLE 6-B

CONSUMPTION AND COSTS OF FEDERAL BUILDINGS ENERGY

BY FUEL TYPE IN FY 1997, FY 1996, AND FY 1985

(Constant 1997 Dollars)

\begin{tabular}{|c|c|c|c|}
\hline ENERGY TYPE & $\begin{array}{c}\text { BILLIONS OF } \\
\text { BTU }\end{array}$ & $\begin{array}{l}\text { COST PER } \\
\text { MMBTU }\end{array}$ & $\begin{array}{c}\text { COST (IN MILLIONS } \\
\text { OF DOLLARS) }\end{array}$ \\
\hline \multicolumn{4}{|l|}{ FY 1997} \\
\hline ELECTRICITY & $145,867.3$ & 17.5485 & $2,559.755$ \\
\hline FUEL OIL & $39,596.5$ & 4.9853 & 197.401 \\
\hline NATURAL GAS & $126,392.9$ & 4.1109 & 519.590 \\
\hline LPG/PROPANE & $2,411.4$ & 9.1863 & 22.152 \\
\hline COAL & $18,873.3$ & 2.1510 & 40.597 \\
\hline PURCHASEO STEAM & $15,679.8$ & 13.5639 & 212.679 \\
\hline OTHER & $1,508.5$ & 5.1626 & 7.788 \\
\hline TOTAL & $350,329.7$ & & $3,559.962$ \\
\hline \multicolumn{4}{|c|}{ COMBINED COST PER MMBTU $=\$ 10.162$} \\
\hline \multicolumn{4}{|l|}{ FY 1996} \\
\hline ELECTRICITY & $149,200.1$ & 18.1595 & $2,709.393$ \\
\hline FUEL OIL & $49,344.6$ & 4.8357 & 238.616 \\
\hline NATURAL GAS & $121,335.3$ & 3.8937 & 472.442 \\
\hline LPG/PROPANE & $2,795.1$ & 7.8471 & 21.934 \\
\hline COAL & $18,180.9$ & 2.3270 & 42.307 \\
\hline PURCHASED STEAM & $17,425.4$ & 12.3853 & 215.819 \\
\hline OTHER & 173.7 & 29.9101 & 5.195 \\
\hline TOTAL & $358,455.2$ & & $3,705.707$ \\
\hline \multicolumn{4}{|c|}{ COMBINED COST PER MMBTU $=\$ 10.338$} \\
\hline \multicolumn{4}{|l|}{ FY 1985} \\
\hline ELECTRICITY & $144,693.9$ & 23.8527 & $3,451.351$ \\
\hline FUEL OIL & $107,588.8$ & 8.5576 & 920.702 \\
\hline NATURAL GAS & $144,948.7$ & 6.6113 & 958.307 \\
\hline LPG/PROPANE & $3,604.2$ & 9.9132 & 35.729 \\
\hline COAL & $58,069.5$ & 3.3626 & 195.266 \\
\hline PURCHASED STEAM & $8,006.4$ & 16.1388 & 129.215 \\
\hline OTHER & $4,709.9$ & 6.9033 & 32.514 \\
\hline TOTAL & $471,621.4$ & & $5,723.085$ \\
\hline \multicolumn{4}{|c|}{ COMBINED COST PER MMBTU $=\$ 12.135$} \\
\hline DATA AS OF 01/29/99 & & & \\
\hline
\end{tabular}

Note: $\quad$ FY 1996 contains estimated data for the following agencies: FEMA, FTC, and OPM; FY 1997 contains estimated data for: FEMA, FCC, FTC, and OPM.

This table uses a conversion factor for electricity of 3,412 Btu per kilowatt hour. Sum of components may not equal total due to independent rounding.

Source: Federal Agency Annual Energy Management Data Reports 
Electricity costs of $\$ 2,559.8$ million represent approximately 71.9 percent of the total expenditures of $\$ 3,560.0$ million for buildings energy in FY 1997. Natural gas costs account for approximately 14.6 percent of the total, expenditures for fuel oil account for 5.5 percent, with the remaining 8.0 percent attributable to expenditures for LPG/propane, coal, purchased steam, and "other."

In FY 1997, the cost of all energy used in Federal buildings was $\$ 1.18$ per gross square foot. Of the $\$ 1.18$ spent per square foot Government-wide, $\$ 0.85$ was spent for electricity, $\$ 0.17$ was spent for natural gas, $\$ 0.07$ was spent for fuel oil, and the remaining $\$ 0.09$ was spent for purchased steam, coal, LPG/propane, and other fuels.

\section{B. Progress Toward the Mandated Goals for Buildings and Facilities}

Both the magnitude of energy consumption and the potential for energy savings have prompted legislative and executive branch initiatives to achieve energy conservation in the Federal buildings sector. ${ }^{14}$ Federal Government progress toward the 10, 20, and 30 percent energy reduction goals of NECPA and Executive Order 12902 is illustrated in Figure 8. Overall, the Federal Government reduced its net energy consumption in buildings and facilities by 17.0 percent in FY 1997 compared to FY 1985 when measured in terms of British Thermal Units consumed per gross square foot (Btu/GSF) of floor area.

FIGURE 8

Progress Toward the Energy Reduction Goals for Buildings and Facilities, FY 1985 through FY 1997

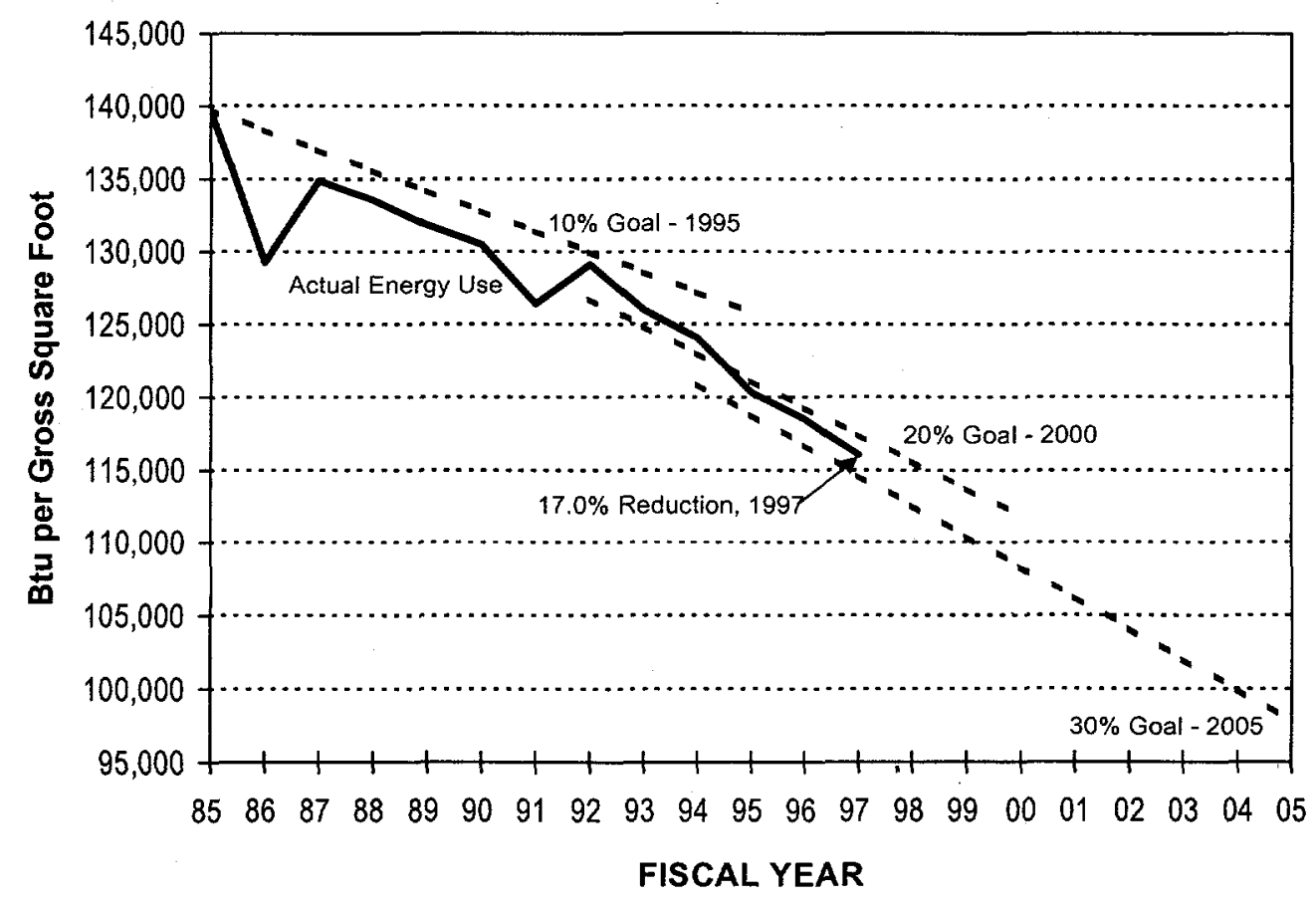

${ }^{14}$ The legislative authorities for Federal agencies are detailed in Appendix A. 
Table 7-A shows the FY 1997 performance of the individual agencies in net Btu/GSF compared to FY 1985. Net Btu reflects the amount of energy delivered to the point of use and is used to measure agency performance toward the mandated goals.

Table 7-B shows the performance of the agencies measured in terms of primary Btu/GSF. Primary Btu represents the average amount of energy required at the source of generation (primary energy) rather than the actual Btu delivered to the site. Primary Btu includes energy resources used to generate, process, and transport electricity and steam. Measured in terms of source energy, the Federal Government shows a reduction of 4.0 percent in FY 1997 compared to FY 1985. This large difference from the net Btu/GSF reduction of 17.0 percent reflects the significant declines in direct use of fossil fuels and the offsetting increases in the share of the fuel mix contributed by electricity.

Contributing to the overall reduction of 17.0 percent in net Btu/GSF were the percentage reductions greater than 10 percent made by the following 13 agencies: the Departments of Agriculture, Defense, Commerce, Energy, Justice, Veterans Affairs, the Interior, Transportation, and the General Services Administration, National Aeronautics and Space Administration, Environmental Protection Agency, the Tennessee Valley Authority, and the United States Postal Service.

These agencies used a variety of strategies to reduce their energy consumption. Operations and maintenance $(\mathrm{O} \& \mathrm{M})$ procedures continued to be emphasized as a major component in the effort to achieve the energy reduction goals. Improvements in energy efficiency were achieved through improved energy systems operations and both preventive maintenance and improved maintenance. O\&M funding, used for the replacement of boilers, HVAC equipment, windows, and lighting systems, continued to benefit energy conservation.

In FY 1997, the implementation of many no-cost and low-cost energy conservation measures was continued, such as reducing lighting levels, lowering hot water temperatures, turning off unused equipment, and installing energy-efficient windows, insulation, weather stripping, and set-back thermometers.

Numerous energy-efficient building retrofits and energy conservation projects were undertaken to supplement the no-cost, low-cost measures. These initiatives can be categorized by lighting system replacement, HVAC equipment modernization, building envelope improvements, and other miscellaneous projects, such as installation of energy management control systems. Utilitysponsored demand side management programs were often pursued as supplemental sources of funding, as well as energy savings performance contract initiatives.

Other activities include energy awareness programs featuring energy awareness seminars, the identification of no-cost or low-cost measures, the designation of building energy monitors, publication of materials promoting energy efficiency, the procurement of energy-efficient goods and products, increased maintenance training, and increased engineering assistance. 
TABLE 7-A

\section{FEDERAL BUILDINGS AND FACILITIES NET ENERGY USE PER GROSS SQUARE FOOT, FY 1985 AND FY 1997}

FISCAL YEAR 1985

GSF

(Thousands) (Billions) BTU/GSF

$\begin{array}{lrrr}\text { VA } & 123,650.0 & 24,552.0 & \mathbf{1 9 8 , 5 6 0} \\ \text { DOE } & 73,415.8 & 32,923.2 & \mathbf{4 4 8 , 4 4 9} \\ \text { USPS } & 189,400.0 & 16,238.3 & \mathbf{8 5 , 7 3 6} \\ \text { GSA } & 196,341.4 & 16,563.0 & \mathbf{8 4 , 3 5 8} \\ \text { DOJ } & 20,768.8 & 6,112.0 & \mathbf{2 9 4 , 2 8 9} \\ \text { HHS } & 22,611.3 & 6,610.2 & \mathbf{2 9 2 , 3 4 0} \\ \text { NASA } & 11,509.0 & 2,948.0 & \mathbf{2 5 6 , 1 4 9} \\ \text { DOT } & 32,007.8 & 4,500.3 & \mathbf{1 4 0 , 5 9 9} \\ \text { DOI } & 54,154.4 & 4,762.4 & \mathbf{8 7 , 9 4 0} \\ \text { DOL } & 18,268.3 & 2,153.0 & \mathbf{1 1 7 , 8 5 2} \\ \text { USDA } & 28,980.5 & 2,096.3 & \mathbf{7 2 , 3 3 6} \\ \text { TRSY } & 5,776.9 & 615.0 & \mathbf{1 0 6 , 4 6 3} \\ \text { EPA } & 1,931.2 & 772.3 & \mathbf{3 9 9 , 9 2 3} \\ \text { TVA } & 4,886.6 & 402.4 & \mathbf{8 2 , 3 5 7} \\ \text { DOC } & 4,522.6 & 540.3 & \mathbf{1 1 9 , 4 7 6} \\ \text { ST } & 2,597.0 & 232.1 & \mathbf{8 9 , 3 9 0} \\ \text { HUD } & 1,432.0 & 116.9 & \mathbf{8 1 , 6 6 8} \\ \text { PCC } & 492.5 & 26.6 & \mathbf{5 4 , 0 7 9} \\ \text { FCC } & 121.0 & 11.2 & \mathbf{9 2 , 1 8 2} \\ \text { OTHER* } & 2,558.5 & 369.0 & \mathbf{1 4 4 , 2 3 2}\end{array}$

CIVILIAN AGENCIES

$\begin{array}{lrrrrrrr}\text { TOTAL } & 795,425.6 & 122,544.7 & 154,062 & 993,670.9 & 123,259.7 & 124,045 & -19.5 \\ \text { DOD } & 2,578,984.0 & 349,076.7 & 135,354 & 2,026,870.0 & 227,070.0 & 112,030 & -17.2 \\ \text { TOTAL } & 3,374,409.6 & 471,621.4 & 139,764 & 3,020,540.9 & 350,329.7 & 115,982 & -17.0 \\ & & & & & & \text { DATA AS OF 01/29/99 }\end{array}$

FISCAL YEAR 1997

\begin{tabular}{|c|c|c|c|}
\hline $\begin{array}{c}\text { GSF } \\
\text { (Thousands) }\end{array}$ & $\begin{array}{c}\text { BTU } \\
\text { (Billions) }\end{array}$ & BTU/GSF & $\begin{array}{c}\% \text { CHANGE } \\
1985-1997\end{array}$ \\
\hline $151,225.0$ & $26,062.0$ & 172,339 & -13.2 \\
\hline $87,131.7$ & $24,404.4$ & 280,086 & -37.5 \\
\hline $292,125.8$ & $22,006.4$ & 75,332 & -12.1 \\
\hline $183,077.1$ & $13,353.7$ & 72,940 & -13.5 \\
\hline $43,014.1$ & $8,003.7$ & 186,072 & -36.8 \\
\hline $25,587.0$ & $7,417.8$ & 289,907 & -0.8 \\
\hline $20,485.6$ & $3,925.0$ & 191,599 & -25.2 \\
\hline $33,570.2$ & $3,800.1$ & 113,198 & -19.5 \\
\hline $48,945.4$ & $3,615.4$ & 73,866 & -16.0 \\
\hline $18,582.5$ & $2,153.9$ & 115,912 & -1.6 \\
\hline $37,917.9$ & $1,996.0$ & 52,641 & -27.2 \\
\hline $11,836.5$ & $1,904.4$ & 160,894 & 51.1 \\
\hline $2,850.1$ & $1,011.5$ & 354,893 & -11.3 \\
\hline $9,756.3$ & 665.6 & 68,226 & -17.2 \\
\hline $5,635.0$ & 457.2 & 81,127 & -32.1 \\
\hline $3,438.4$ & 337.5 & 98,158 & 9.8 \\
\hline $1,432.0$ & 109.3 & 76,340 & -6.5 \\
\hline 500.9 & 33.9 & 67,708 & 25.2 \\
\hline 124.8 & 12.8 & 102,204 & 10.9 \\
\hline $16,434.6$ & $1,989.1$ & 121,029 & -16.1 \\
\hline $993,670.9$ & $123,259.7$ & 124,045 & -19.5 \\
\hline $2,026,870.0$ & $227,070.0$ & 112,030 & -17.2 \\
\hline $3,020,540.9$ & $350,329.7$ & 115,982 & -17.0 \\
\hline & & DAT & \\
\hline
\end{tabular}

*Other includes the Federal Trade Commission, Federal Emergency Management Agency, National Archives and Records Administration, National Science Foundation, Nuclear Regulatory Commission, Office of Personnel Management, Railroad Retirement Board, the U.S. Information Agency, and the Federal Energy Regulatory Commission.

Note: This table uses a conversion factor for electricity of 3,412 Btu per kilowatt hour.

Sum of components may not equal total due to independent rounding;

Source: Federal Agency Annual Energy Management Data Reports 
TABLE 7-B

FEDERAL BUILDINGS AND FACILITIES PRIMARY ENERGY USE PER GROSS SQUARE FOOT, FY 1985 AND FY 1997

FISCAL YEAR 1985

GSF

(Thousands)

$189,400.0$

$73,415.8$

$123,650.0$

$196,341.4$

$20,768.8$

$22,611.3$

$11,509.0$

$32,007.8$

$54,154.4$

$5,776.9$

$28,980.5$

$18,268.3$

$4,886.6$

$1,931.2$

$4,522.6$

$2,597.0$

$1,432.0$

492.5

121.0

$2,558.5$
BTU

(Billions) BTU/GSF

$39,441.0 \quad \mathbf{2 0 8 , 2 4 2}$

$57,430.1 \quad 782,258$

$42,333.7 \quad 342,367$

$41,207.0 \quad 209,874$

$8,962.7 \quad \mathbf{4 3 1 , 5 4 5}$

$12,605.4 \quad 557,484$

$6,373.5 \quad 553,783$

$8,298.7 \quad 259,270$

$8,432.5 \quad 155,713$

$1,451.0 \quad 251,178$

$4,347.2$

$3,687.8$

$1,321.0$

$1,618.3$

$1,189.1$

689.2

349.3

90.5

29.5

947.5
150,004

201,871

270,333

838,001

262,925

265,377

243,951

183,854

244,132

370,333
FISCAL YEAR 1997

$\begin{array}{rrrr}\begin{array}{c}\text { GSF } \\ \text { (Thousands) }\end{array} & \begin{array}{c}\text { BTU } \\ \text { (Billions) }\end{array} & \text { BTU/GSF } & \begin{array}{r}\text { \%CHANGE } \\ 1985-1997\end{array} \\ & & & \\ 292,125.8 & 53,728.0 & 183,921 & -11.7 \\ 87,131.7 & 51,709.7 & \mathbf{5 9 3 , 4 6 6} & -24.1 \\ 151,225.0 & 48,419.3 & \mathbf{3 2 0 , 1 8 0} & -6.5 \\ 183,077.1 & 34,492.7 & \mathbf{1 8 8 , 4 0 5} & -10.2 \\ 43,014.1 & 14,681.7 & \mathbf{3 4 1 , 3 2 4} & -20.9 \\ 25,587.0 & 14,320.3 & \mathbf{5 5 9 , 6 7 2} & 0.4 \\ 20,485.6 & 9,857.0 & \mathbf{4 8 1 , 1 6 6} & -13.1 \\ 33,570.2 & 9,378.3 & \mathbf{2 7 9 , 3 6 4} & 7.8 \\ 48,945.4 & 7,024.2 & \mathbf{1 4 3 , 5 1 0} & -7.8 \\ 11,836.5 & 4,802.7 & \mathbf{4 0 5 , 7 5 4} & 61.5 \\ 37,917.9 & 4,701.3 & \mathbf{1 2 3 , 9 8 6} & -17.3 \\ 18,582.5 & 4,079.0 & \mathbf{2 1 9 , 5 0 6} & 8.7 \\ 9,756.3 & 2,250.3 & \mathbf{2 3 0 , 6 5 0} & -14.7 \\ 2,850.1 & 2,075.0 & \mathbf{7 2 8 , 0 3 7} & -13.1 \\ 5,635.0 & 1,303.3 & \mathbf{2 3 1 , 2 8 9} & -12.0 \\ 3,438.4 & 968.1 & \mathbf{2 8 1 , 5 6 6} & 6.1 \\ 1,432.0 & 320.6 & \mathbf{2 2 3 , 8 6 3} & -8.2 \\ 500.9 & 115.3 & \mathbf{2 3 0 , 1 9 4} & 25.2 \\ 124.8 & 31.7 & \mathbf{2 5 3 , 8 3 8} & 4.0 \\ 16,434.6 & 5,292.9 & \mathbf{3 2 2 , 0 5 8} & -13.0 \\ & & & \\ 993,670.9 & 269,551.3 & \mathbf{2 7 1 , 2 6 8} & -10.4 \\ & & & -4.3 \\ 2,026,870.0 & 436,940.7 & \mathbf{2 1 5 , 5 7 4} & \\ & & & -4.0 \\ 3,020,540.9 & 706,492.1 & \mathbf{2 3 3 , 8 9 6} & \\ & & & \text { DATA AS OF 01/29/99 }\end{array}$

*Other includes the Federal Trade Commission, Federal Emergency Management Agency, National Archives and Records Administration, National Science Foundation, Nuclear Regulatory Commission, Office of Personnel Management, Railroad Retirement Board, the U.S. Information Agency, and the Federal Energy Regulatory Commission.

Note: This table uses a conversion factor for electricity of 11,600 Btu per kilowatt hour and 1,390 Btu per pound of steam. Sum of components may not equal total due to independent rounding.

Source: Federal Agency Annual Energy Management Data Reports 
A number of agencies began submitting energy data to DOE starting in FY 1989 in compliance with NECPA as amended by the Federal Energy Management Improvement Act of 1988 (Pub. L. 100-615). Among these agencies are the Department of State, the Office of Personnel Management, and the Federal Energy Regulatory Commission. These three agencies submitted historical energy data back to FY 1985.

For FY 1990 and forward, Federal Energy Regulatory Commission energy consumption is reported as part of DOE and is therefore grouped under the category of "Other." Other agencies grouped under the category of "Other" in the tables had no buildings data to report for FY 1985. These agencies include the Federal Trade Commission, the National Archives and Records Administration, the Nuclear Regulatory Commission, the Railroad Retirement Board, and the U.S. Information Agency. The National Science Foundation, Federal Emergency Management Agency, and Office of Personnel Management are also grouped under this category due to lack of reporting in more recent years.

In FY 1997, GSA continued to delegate building management authority to agencies that occupy buildings owned and operated by GSA. As a result, several agencies reported increased gross square footage and energy consumption relative to FY 1985, while GSA reported decreases in these categories during the same period. The GSA delegation accounts for the significant interyear changes in energy consumption reported by various individual agencies. Two agencies, the Department of Health and Human Services and the Department of Commerce, adjusted their baseline year consumption and GSF figures during FY 1988 to reflect GSA delegations. DOC added the Jeffersonville Federal Center to its data reports, which greatly increased its gross square footage. In addition, three Commerce Bureaus, the Bureau of Economic Affairs, the National Technical Information Service, and the Patent and Trademark Office, all became eligible for reporting in FY 1989 as a result of leasing delegation.

The Treasury Department's large increase in buildings energy consumption since FY 1985, is a result of the addition of the Internal Revenue Service delegated buildings to the Department's building inventory. Also contributing to the Treasury's increase was the additions, in FY 1989, of the Office of Thrift Supervision's square footage and the GSA delegation of building management authority for the Financial Management Service. The energy consumption and square footage for these delegated buildings were included in GSA's FY 1985 reports. 
Figure 9 illustrates the range of energy intensity in agency buildings measured in terms of Btu/GSF. High rates of energy intensity at the EPA, HHS, and DOE reflect the special requirements of their laboratory and research facilities. At DOE, if more than 80 percent of a facility's metered energy is dedicated to process operations, then the entire facility's energy is excluded from the buildings category, according to how DOE defines its buildings and facilities. The Interior Department's relatively low Btu/GSF results from the lack of energy intensive activities (i.e., laboratories, hospitals, etc.) in space under its control. The wide range of rates of Btu/GSF among different agencies is a result of the varying missions of the agencies as well as their varying criteria for excluding energy intensive facilities.
FIGURE 9

Range of Energy Intensity (Btu/GSF) in Buildings and Facilities by Agency in FY 1997

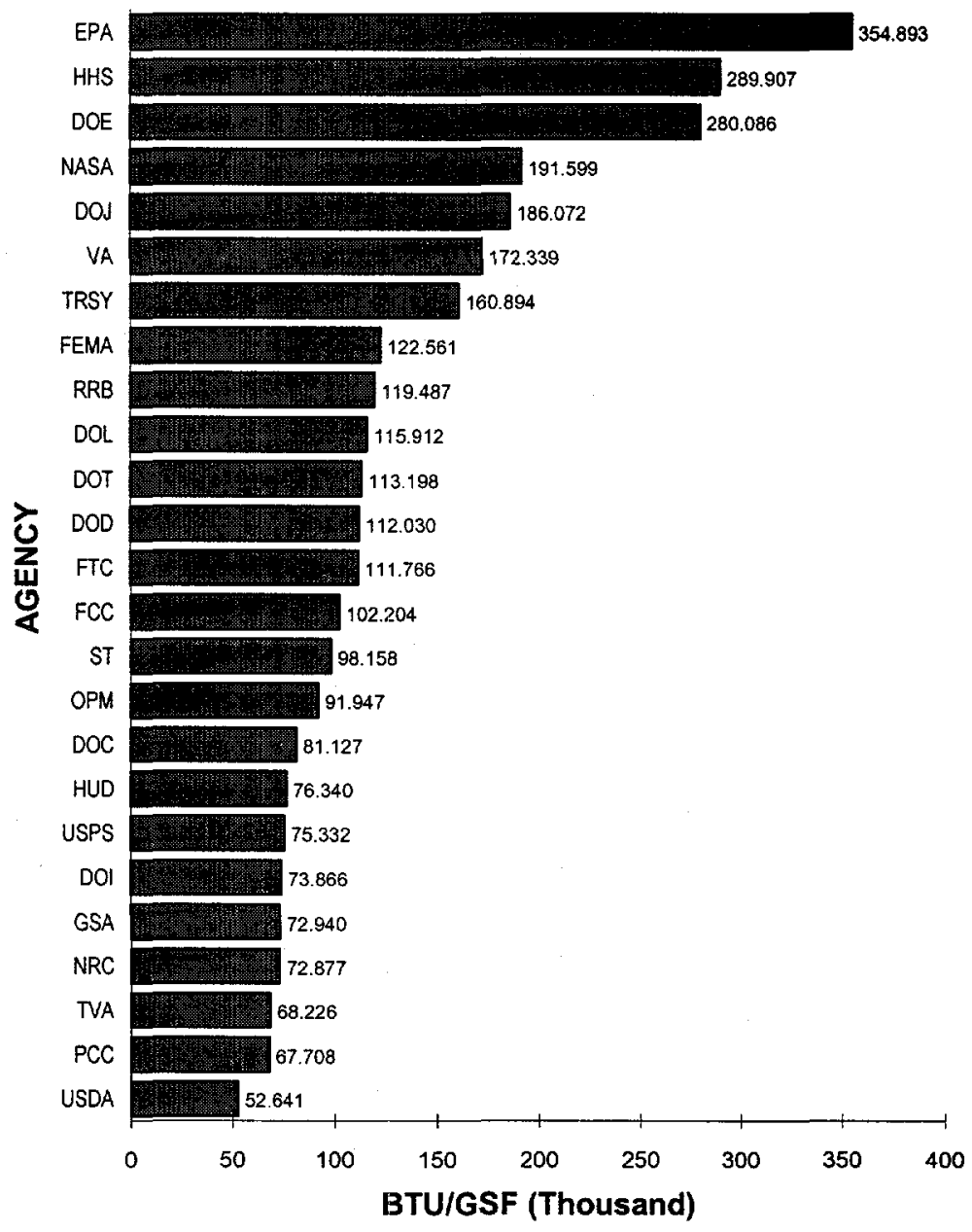

\section{Energy Star Program Participation}

The Federal Energy Star Buildings Program Memorandum of Understanding (MOU) was signed by Mary Nichols, Environmental Protection Agency (EPA), and Christine Ervin, Assistant Secretary for Energy Efficiency and Renewable Energy, Department of Energy, in March 1997.

During FY 1997, several Federal agencies took actions regarding both the Federal Energy Star Buildings and the Green Lights programs:

- Department of Defense. The Norfolk District, Army Corps of Engineers, in a joint demonstration with DOD and the EPA, developed a military housing design to achieve an "EPA 5 Star Energy Efficiency Rating" for 135 family housing units at Fort Lee, Virginia. 
- Department of the Interior. In conjunction with EPA and DOE, DOI prepared a MOU to participate in the Federal Energy Star Program partnerships. This MOU was forwarded to the Interior's Assistant Secretary for Policy, Management and Budget.

- Department of Transportation. The United States Coast Guard is actively engaged in the development of eight Energy Star buildings that will become showcase buildings upon project completion.

- Environmental Protection Agency. Several EPA facility construction projects demonstrate Energy Star Buildings technologies and concepts including the New Headquarters Buildings (Washington, DC), the New Consolidated RTP Facility (Research Triangle Park, NC), the Region IV Science and Ecosystems Support Laboratory (Athens, GA), Region IV Office (Atlanta, GA), Region III Office (Philadelphia, PA), Region VII Central Regional Laboratory (Kansas City, KS), National Vehicle and Fuel Emissions Laboratory (Ann Arbor, MI), and the Fort Meade Environmental Science Center (Fort Meade, MD).

- Department of Health and Human Services. The HHS Energy Officer and the operating division energy coordinators met with EPA to discuss the Federal Energy Star Buildings program. Each HHS operating division will sign a MOU which will be forwarded to operating division heads with a cover letter encouraging participation from the Office of the Secretary's Assistant Secretary for Management and Budget.

- National Aeronautics and Space Administration. Both Goddard Space Flight Center and the Santa Susana Field Laboratory participate in the Green Lights program.

- Tennessee Valley Authority (TVA). TVA is in the process of becoming a partner in the Federal Energy Star Buildings program. As a member of the Green Lights program, TVA developed the SWAP program to eliminate the cycle time for lighting upgrades and to reduce survey and design cost as part of these efforts. SWAP II, which will evaluate the implementation of lighting controls as a first step in the reduction of energy, will be initiated in FY 1998.

- United States Postal Service. Signed MOU with EPA to participate in the Federal Energy Star Buildings program. 


\section{Federal Building Energy Performance Standards}

Federal agencies are subject to the provisions of $10 \mathrm{CFR}$ part 435, subpart A, which set forth interim building energy performance standards for new Federal buildings. Standards for new Federal buildings are issued under the Energy Conservation Standards in New Buildings Act of 1976, as amended, 42 U.S.C. 6831 et seq, and under Title V, subtitle H, of the Energy Security Act, 42 U.S.C. $\S 8286$ and 8286a. On August 6, 1996, the Department of Energy issued a proposed rule in the Federal Register, 61 FR 40882, to revise the 1989 interim rule, 10 CFR part 435 , which established energy efficiency voluntary performance standards for design of new Federal commercial and multi-family high-rise residential buildings.

EPACT mandates that new Federal buildings must contain energy saving and renewable energy specifications that meet or exceed the energy saving and renewable energy specifications of the American Society of Heating, Refrigerating and Air Conditioning Engineers (ASHRAE)/ Illuminating Engineering Society of North America (IES) Standard 90.1-1989 and the Council of American Building Officials Model Energy Codes (MEC) 1992.

Furthermore, Executive Order 12902, which was designed to assist agencies in meeting or exceeding the Federal energy and water efficiency provisions contained in EPACT, requires each agency involved in the construction of a new facility that will be either owned by or leased to the Government to:

(1) design and construct such facility to minimize the life-cycle cost of the facility by utilizing energy efficiency, water conservation, or solar or other renewable energy technologies;

(2) ensure that the design and construction of facilities meet or exceed the energy performance standards applicable to Federal residential or commercial buildings as set forth in 10 CFR 435, local building standards, or a Btu-per-gross-square-foot ceiling as determined by the Task Force within 120 days of the date of this order, whichever will result in a lower life-cycle cost over the life of the facility;

(3) establish and implement, within 270 days of the date of this order, a facility commissioning program that will ensure that the construction of such facilities meets the requirements outlined in this section before the facility is accepted into the Federal facility inventory; and

(4) utilize passive solar design and adopt active solar technologies, where cost-effective.

The Department of Energy has endeavored to fulfill these requirements by developing common energy conservation standards for all new Federal buildings and by issuing life-cycle costing procedures for use by Federal agencies in the assessment of energy conserving investments for existing buildings.

In response to the Executive Order 12902 requirement for Federal agencies to establish and implement a facility commissioning program, DOE formed the New Space Working Group under the Federal Interagency Energy Management Task Force. The Working Group, in conjunction with GSA and other Federal agencies, drafted a Building Commissioning Guide 
which has been distributed to agencies for final comment. The Guide is designed to help all parties involved in the planning, design, construction, acceptance, and post-acceptance phases work together to produce a building that operates according to design intent and provides occupant comfort and energy savings. The draft Guide will be posted on the Federal Energy Management Program's Internet Web site at www.eren.doe.gov/femp for use during the review process.

A proposed rule, Energy Code for New Federal Commercial and Multi-Family High Rise Residential Buildings, revises the interim Federal standards to conform generally with the codified version of ASHRAE Standard 90.1-1989 and incorporates changes in the areas of lighting, mechanical ventilation, motors, building envelope, and fenestration rating procedures, and test procedures for heating and cooling equipment. Since Standard 90.1-1989 is written as a standard of professional practice, it cannot be directly adopted as a building code. DOE's New Space Working Group expressed concern that the Energy Code be concise as possible, publishing the minimal exceptions to the commercial standard, rather than publishing an entire new energy code. Using one standard would allow the architect/engineer community to focus on designing energy saving elements, rather than on implementing an unique Federal standard. The Working Group also recommended that an electronic version of the codified rule be placed on the Internet. The final version of the Energy Code is expected to be published by DOE in June 1998.

A separate proposed rule for new Federal residential buildings was issued by the Department of Energy in the Federal Register in May 1997. The proposed rule, Energy Code for New Federal Residential Buildings, uses the Model Energy Code (MEC) format and contains performance standards from the current Federal residential standard, the MEC, and the codified version of ASHRAE Standard 90.2-1993 that are economically justified and technologically feasible.

DOE has also worked closely with HUD in coordinating the technical factors and data used to develop HUD's Manufactured Housing Standards and has committed to work closely with all Federal agencies to coordinate and upgrade the standards applied by these agencies to nonFederal buildings.

DOE is concurrently working on a model commissioning plan based on a GSA plan for a Federal courthouse in Portland, Oregon. This model will be more detailed than the Building Commissioning Guide and will include forms, model plans, training, and acceptance procedures for the building. 


\section{ENERGY INTENSIVE OPERATIONS IN FEDERAL FACILITIES}

\section{A. Energy Consumption and Costs for Energy Intensive Operations}

NECPA, as amended, 42 U.S.C. $\S 8253$, allows agencies to exclude from the buildings goal, facilities which house energy intensive activities. The energy consumed in these facilities is reported under the category of excluded/process energy. The reporting of energy used in excluded buildings assures that total Federal energy consumption is monitored.

The designation of excluded buildings is at the discretion of each agency. Currently, 15 agencies are excluding specific facilities from the NECPA goal: the Departments of Agriculture, Commerce, Defense, Energy, Justice, State, Transportation, and the Treasury, the General Services Administration, the National Aeronautics and Space Administration, the National Archives and Records Administration, the Panama Canal Commission, the Social Security Administration, the Tennessee Valley Authority, and the U.S. Information Agency. Lists of the excluded buildings that have been identified by the agencies are included in Appendix D.

Table 8 shows that fuels consumed by excluded/process energy have increased 67.4 percent compared to FY 1985 and decreased 10.3 percent from FY 1996. During FY 1997, the Department of Defense consumed 35.7 trillion Btu of excluded/process energy, 53.7 percent of all excluded/process energy used by the Federal Government.

Some of the fluctuations in consumption of excluded/process energy resulted from agencies changing data collection and reporting procedures. The Social Security Administration began reporting its energy separately from the Department of Health and Human Services in FY 1996 and has elected to exclude check processing facilities as energy intensive. In FY 1994, the Tennessee Valley Authority began reporting electricity used for certain processes of its generating plants. The Department of Justice also commenced reporting energy consumption in its excluded buildings during FY 1994. Increases in consumption of excluded/process energy compared to FY 1985 is also partially attributable to DOD's reallocation, beginning in the FY 1988 reporting year, of energy previously reported in the buildings category to the process category. Also contributing to this increase was the Treasury Department's initial reporting of process energy in FY 1991. Treasury neither reported process energy prior to 1991 nor revised its building energy consumption prior to 1990 to exclude process energy. NASA began reporting process energy in FY 1989 and has revised its prior year data. As a result of the prioritization survey required by Executive Order 12902, NASA redesignated the entire Dryden Flight Research Center, virtually all of the White Sands Test Facility, and many individual facilities at the Goddard Space Flight Center and the Langley Research Center as non-exempt facilities in FY 1996. NASA also redesignated the entire Michoud Assembly Facility as an industrial facility. USIA also began reporting energy under this category in FY 1989. USIA has not reported any process energy consumption for any prior years. GSA began reporting energy in excluded buildings in FY 1990 and has backed out this energy consumption from its FY 1985 buildings data. The Departments of Agriculture and Commerce both began excluding buildings where energy intensive activities occur in FY 1992. USDA revised all of its prior year buildings data back to FY 1985 to reflect the exclusion of the Agricultural Research Service. The Commerce 


\section{TABLE 8}

FEDERAL ENERGY CONSUMPTION IN EXCLUDED BUILDINGS/PROCESS OPERATIONS

(In Billions of Btu, with Conversions to Millions of Barrels of Oil Equivalent [MBOE], and Petajoules [Joule $\times 10^{15}$ ])

\begin{tabular}{|c|c|c|c|c|c|c|c|c|c|c|c|c|c|c|c|}
\hline & $\begin{array}{l}\text { CIVILIAN } \\
\text { AGENCY }\end{array}$ & $\begin{array}{c}\text { FY } \\
1985\end{array}$ & $\begin{array}{c}\text { FY } \\
1986\end{array}$ & $\begin{array}{c}F Y \\
1987\end{array}$ & $\begin{array}{c}F Y \\
1988\end{array}$ & $\begin{array}{c}F Y \\
1989\end{array}$ & $\begin{array}{c}F Y \\
1990\end{array}$ & $\begin{array}{c}F Y \\
1991\end{array}$ & $\begin{array}{c}\text { FY } \\
1992\end{array}$ & $\begin{array}{c}F Y \\
1993\end{array}$ & $\begin{array}{c}F Y \\
1994\end{array}$ & $\begin{array}{c}F Y \\
1995\end{array}$ & $\begin{array}{c}F Y \\
1996\end{array}$ & $\begin{array}{c}F Y \\
1997\end{array}$ & $\begin{array}{c}\text { \%CHANGE } \\
85-97\end{array}$ \\
\hline & DOE & $16,401.6$ & $15,439.8$ & $14,929.5$ & $15,239.0$ & $12,581.2$ & $11,649.9$ & $11,541.3$ & $12,657.8$ & $10,900.5$ & $11,000.3$ & $17,236.2$ & $16,876.6$ & $7,541.4$ & -54.0 \\
\hline & NASA & $5,907.2$ & $6,242.2$ & $6,479.8$ & $6,569.7$ & $7,206.4$ & $7,376.6$ & $7,490.8$ & $7,558.5$ & $7,612.9$ & $7,819.0$ & $7,419.5$ & $6,479.4$ & $6,453.9$ & 9.3 \\
\hline & USDA & $1,942.8$ & $1,655.3$ & $1,530.5$ & $1,657.5$ & $2,026.0$ & $2,204.2$ & $2,133.3$ & $1,966.3$ & $2,166.9$ & $2,119.3$ & $2,824.0$ & $2,140.8$ & $3,918.3$ & 101.7 \\
\hline & DOT & $2,885.1$ & $3,318.9$ & $3,615.8$ & $3,727.3$ & $3,724.6$ & $3,064.0$ & $3,323.0$ & $4,406.8$ & $4,703.8$ & $2,952.5$ & $2,349.4$ & $3,178.1$ & $3,024.6$ & 4.8 \\
\hline & USPS & 0.0 & 0.0 & 0.0 & 0.0 & 0.0 & 0.0 & 0.0 & 0.0 & 0.0 & 0.0 & 0.0 & 0.0 & $1,974.4$ & N/A \\
\hline & DOC & 938.6 & 0.0 & 0.0 & 0.0 & 0.0 & 0.0 & 0.0 & 976.6 & 770.8 & $1,110.2$ & $1,627.4$ & $1,823.0$ & $1,335.2$ & 42.3 \\
\hline & TVA & 0.0 & 0.0 & 0.0 & 0.0 & 0.0 & 0.0 & 0.0 & 0.0 & 0.0 & $1,390.6$ & $1,317.1$ & $1,235.6$ & $1,251.8$ & N/A \\
\hline & TRSY & 0.0 & 0.0 & 0.0 & 0.0 & 0.0 & 0.0 & $1,026.8$ & 814.1 & 923.7 & 771.8 & 941.0 & 928.3 & $1,131.8$ & N/A \\
\hline & USIA & 0.0 & 0.0 & 0.0 & 0.0 & $1,354.4$ & $1,406.9$ & 850.6 & 828.5 & 796.8 & 861.1 & 878.2 & 936.2 & $1,092.2$ & N/A \\
\hline & GSA & 623.6 & 0.0 & 0.0 & 0.0 & 0.0 & 160.6 & 746.2 & 677.6 & 994.6 & $1,060.2$ & $1,213.8$ & 961.0 & 890.7 & 42.8 \\
\hline & DOJ & 0.0 & 0.0 & 0.0 & 0.0 & 0.0 & 0.0 & 0.0 & 0.0 & 0.0 & 668.4 & 707.8 & 944.1 & 846.9 & N/A \\
\hline & NARA & 0.0 & 0.0 & 0.0 & 0.0 & 0.0 & 0.0 & 0.0 & 0.0 & 274.7 & 610.7 & 792.2 & 562.9 & 572.7 & N/A \\
\hline$\sigma$ & ST & 0.0 & 0.0 & 0.0 & 0.0 & 0.0 & 0.0 & 0.0 & 0.0 & 337.4 & 339.4 & 344.4 & 364.1 & 339.1 & N/A \\
\hline$\mapsto$ & PCC & 167.2 & 179.2 & 185.7 & 190.0 & 187.6 & 190.8 & 197.1 & 193.9 & 197.5 & 201.3 & 209.4 & 218.6 & 221.2 & 32.3 \\
\hline & SSA & 0.0 & 0.0 & 0.0 & 0.0 & 0.0 & 0.0 & 0.0 & 0.0 & 0.0 & 0.0 & 0.0 & 215.5 & 204.7 & $N / A$ \\
\hline & \multicolumn{15}{|c|}{ CIVILIAN AGENCIES } \\
\hline & TOTAL & $28,866.0$ & $26,835.4$ & $26,741.3$ & $27,383.5$ & $27,080.2$ & $26,052.9$ & $27,309.0$ & $30,080.1$ & $29,679.5$ & $30,904.6$ & $37,860.3$ & $36,864.3$ & $30,799.0$ & 6.7 \\
\hline & DOD & $10,857.2$ & $11,449.9$ & $11,890.3$ & $42,284.8$ & $36,792.9$ & $39,209.1$ & $56,372.1$ & $67,913.1$ & $41,159.3$ & $39,781.4$ & $37,962.6$ & $37,260.1$ & $35,702.3$ & 228.8 \\
\hline & \multicolumn{15}{|c|}{ ALL AGENCIES } \\
\hline & TOTAL & $\begin{array}{r}39,723.2 \\
-10.3\end{array}$ & $38,285.3$ & $38,631.6$ & $69,668.3$ & $63,873.1$ & $65,262.1$ & $83,681.1$ & $97,993.2$ & $70,838.9$ & $70,686.0$ & $75,822.8$ & $74,124.4$ & $66,501.2$ & 67.4 \\
\hline & MBOE & 6.8 & 6.6 & 6.6 & 12.0 & 11.0 & 11.2 & 14.4 & 16.8 & 12.2 & 12.1 & 13.0 & 12.7 & 11.4 & \\
\hline & Petajoules & 41.9 & 40.4 & 40.8 & 73.5 & 67.4 & 68.8 & 88.3 & 103.4 & 74.7 & 74.6 & 80.0 & 78.2 & 70.2 & \\
\hline
\end{tabular}

Note: This table uses a conversion factor for electricity of 3,412 Btu per kilowatt hour.

Sum of components may not equal total due to independent rounding.

Source: Federal Agency Annual Energy Management Data Reports 
Department revised its FY 1985 base year data only to reflect the exclusion of its energy intense facilities. The State Department and NARA began reporting excluded/process energy in FY 1993 and have not revised data for any prior years. The Justice Department commenced reporting of excluded buildings in FY 1994 and has not revised data for any prior years. The U.S. Postal Service began reporting energy consumption under this category in FY 1997 with no revisions to prior years.

Energy used in energy intensive operations accounts for approximately 6.1 percent of the total 1.08 quads used by the Federal Government. Electricity constitutes 41.6 percent of the energy used in energy intensive operations, 36.1 percent is accounted for by natural gas, 5.4 percent by coal, and 11.3 percent by fuel oil. Small amounts of purchased steam, liquefied petroleum gas (LPG)/propane, and "other" energy account for the remaining 5.6 percent.

The energy used in energy intensive operations in FY 1997 accounted for approximately 8.0 percent of the total Federal energy bill. Table 9 shows that the Federal Government spent approximately $\$ 662.2 \mathrm{million}$ for excluded/process energy during the fiscal year. The combined cost of excluded/process energy in FY 1997 was $\$ 9.96$ per million Btu, up 13.8 percent from the combined cost of $\$ 8.75$ reported in FY 1996 (see Appendix C).

\section{B. Statutory Background and Progress Toward Goals for Industrial Facilities}

Under section 543(a)(2) of NECPA, as amended by EPACT, 42 U.S.C. $\S 8253$, buildings that house energy-intensive activities may be excluded from NECPA's performance goal for buildings. These buildings are listed in Appendix D. Most energy used in excluded buildings is process energy. Process energy is consumed in industrial operations, certain R\&D activities, and in electronic-intensive facilities.

Executive Order 12759 expanded the scope of Federal energy management activities beyond the NECPA mandates by establishing goals for industrial operations. It required industrial facilities to increase energy efficiency by at least 20 percent by FY 2000 in comparison to FY 1985 to the extent that measures undertaken are cost-effective and minimize life-cycle costs. Executive Order 12902 changes this goal to require an increase in energy efficiency by at least 20 percent by 2005 as compared to 1990 . Measures undertaken to achieve this goal must be cost-effective, and agencies are also directed to implement all cost-effective water conservation projects. The Executive Order goal applies to certain buildings currently excluded under NECPA where industrial operations are performed. During FY 1994, a working group of the Interagency Energy Management Task Force concentrated efforts on developing appropriate indicators for measuring performance under this goal.

The Department of Defense excludes two types of energy from the NECPA performance goal: process energy and "cold iron" energy. Process energy is used in facilities that perform production or industrial functions. "Cold iron" energy is used to supply power to Navy ships docked in port. Both types of energy are included in this report under the category of excluded/process. 
TABLE 9

DEFENSE AND CIVILIAN FEDERAL COSTS FOR EXCLUDED BUILDINGS/ PROCESS ENERGY IN FY 1997 (In Millions of Dollars)

$\begin{array}{lcccccccc} & \text { ELECTRICITY } & \text { FUEL OIL } & \begin{array}{c}\text { NATURAL } \\ \text { GAS }\end{array} & \begin{array}{c}\text { LPG/ } \\ \text { PROPANE }\end{array} & \text { COAL } & \begin{array}{c}\text { PURCHASED } \\ \text { STEAM }\end{array} & \text { OTHER } & \text { TOTAL } \\ \text { DEFENSE }^{1} & 205.894 & 10.371 & 43.839 & 0.614 & 6.135 & 5.844 & 0.000 & 272.697 \\ \text { CIVILIAN }^{2} & 349.132 & 7.076 & 21.700 & 0.372 & 0.633 & 10.281 & 0.336 & 389.530 \\ \text { TOTAL } & 555.026 & 17.447 & 65.539 & 0.986 & 6.768 & 16.125 & 0.336 & 662.227\end{array}$

AVERAGE COST PER UNIT, BASED ON REPORTS FROM AGENCIES

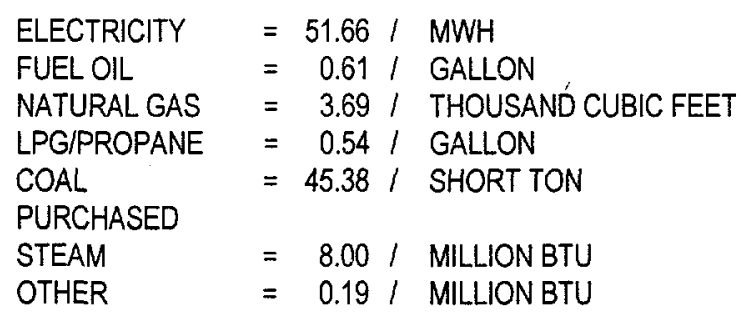

DATA AS OF 07/10/98

${ }^{1}$ Includes DOD costs for process and cold iron energy.

${ }^{2}$ Includes DOE costs for metered process energy and energy costs for buildings excluded from performance measurement by DOC, DOJ, DOT, GSA, NASA, NARA, PCC, SSA, STATE, TRSY, TVA, USDA, and USIA.

Note: Sum of components may not equal total due to independent rounding.

Source: Annual energy cost data submitted to DOE by Federal agencies. 
The Department of Energy reports its use of metered energy in extensive experimental research and production processes under excluded/process energy. The metered process energy used by DOE includes energy consumed in: production nuclear reactors, industrial-type operations for weapons and nuclear fuel production, and research and development facilities such as experimental nuclear reactors and linear accelerators. Excluded/process energy totaled 7.5 trillion Btu in FY 1997, which represents 18.5 percent of all energy consumed by DOE. The use of excluded process energy by DOE in FY 1997 was 54.0 percent less than in FY 1985, and 55.3 percent less than FY 1996. The primary contributor to this one-year decrease was the sale by DOE of the Naval Petroleum Reserve, California, during the fiscal year, and subsequent decreases in natural gas consumption.

NASA excludes from the NECPA performance goal facilities which fall under its definition of mission-variable facilities. These highly specialized, energy-intensive facilities house space science experimental and testing activities, as well as some industrial operations. Examples of these facilities include wind tunnels driven by multi-thousand horsepower electric motors, launch facilities, space simulation chambers, space communication facilities, and research analysis centers. The Michoud Assembly Facility (MAF), which manufactures the Space Shuttle external tank, is the only NASA facility subject to the Executive Order goal for industrial facilities. MAF selected billion Btu (BBtu) per external tank as its industrial energy metric. In the FY 1990 baseline year, MAF total energy consumption was $925.8 \mathrm{BBtu}$ at a production rate of 4.6 external tanks per year, or 201.3 BBtu/external tank. In FY 1997, MAF total energy consumption was 965.3 BBtu at a production rate of 6.0 external tanks per year, or $160.9 \mathrm{BBtu} /$ external tank. This represents a 20.1 percent reduction in energy consumption per external tank produced and an energy efficiency improvement of 25.1 percent.

The Department of Commerce excludes buildings operated by three of its agencies: the National Institute of Standards and Technology (NIST), the National Oceanic and Atmospheric Administration (NOAA), and the Bureau of the Census. NIST installations have been excluded because they are comprised of general purpose and special laboratories that require constant environmental space control and base electrical loads for scientific equipment and computer systems. NOAA Weather Service facilities operate 24 hours a day and consist of radar towers, computers, special gauges, meters and other sophisticated equipment. Marine Fisheries and Laboratories conduct marine biology research and utilize refrigerators, freezers, incubators, coolers, seawater pumps, and compressors that operate 24 hours a day. The Bureau of Census Charlotte Computer Center is a leased facility and is used solely as a computer center. The building is operated 24 hours a day.

Within the Department of Transportation, the Federal Aviation Administration excludes all buildings involved in implementing the National Airspace System Plan. These buildings house energy-intensive electronic equipment with the associated HVAC requirements to maintain an environment for reliable equipment operation.

The U.S. Information Agency designates domestic and overseas Voice of America Relay Stations as energy-intensive facilities and reports this consumption as process energy excluded from the NECPA performance goal. 
A substantial amount of the Panama Canal Commission energy consumption is dedicated to process functions, primarily comprising the locks, industrial, and other canal ancillary or support facilities.

The GSA excludes from the NECPA performance goal those buildings and facilities where energy usage is skewed significantly due to reasons such as: buildings entering or leaving the inventory during the year; buildings down-scaled operationally to prepare for disposal; buildings undergoing major renovation and/or major asbestos removal; or buildings functions like that of outside parking garages which consume essentially only lighting energy, yet are classed as buildings. GSA's excluded buildings, due to these factors, could distort GSA's actual progress toward meeting the energy reduction goal.

Energy reported by the Treasury Department under the category of excluded/process energy is comprised mainly of industrial energy consumption by the Bureau of Engraving and Printing and the Mint.

The State Department excludes unique, special-use facilities with special security and operational requirements including the President's guest house, a computer facility, the International Chancery Center, and the Main State Facility.

NARA designates all 12 of its facilities as energy intensive because of stringent records storage requirements which demand that documents and records be maintained in a controlled environment 24 hours per day, 365 days per year.

The Department of Justice excludes the Justice Data Center in Washington, DC, a 24-hour-a-day energy intensive facility and five installations operated by the Federal Bureau of Investigation which operate 24 hours per day. These facilities have limited conservation measures available. Also exempted by the Justice Department are Immigration and Naturalization Service repeater stations located nationwide that house equipment operations only.

The Social Security Administration, which began reporting energy consumption this year as an independent agency, has designated its National Computer Center as an energy intensive facility. The Center contains SSA's main database and query server and operates 24 hours per day and 365 days per year.

Since 1985, the Postal Service has deployed energy intensive automated equipment which has improved the efficiency of mail operations. Surveys indicate that this equipment deployment has increased process energy usage by 8 percent in FY 1997. The Postal Service energy consumption reported under this category reflects process energy consumed by mail processing equipment. This consumption has been factored out of energy consumption of Postal Service non-excluded buildings in order to provide a better measure of the energy efficiency status of Postal Service facilities. 


\section{ENERGY MANAGEMENT IN VEHICLES AND EQUIPMENT}

\section{A. Energy Consumption and Costs for Vehicles and Equipment}

Vehicle and equipment energy consists of energy used by equipment ranging in size and function from aircraft carriers to forklifts. It includes aircraft and naval fuels, automotive fuels consumed by Federally-owned and leased vehicles and privately-owned vehicles used for official business, and the energy used in Federal construction.

Table 10 shows that in FY 1997, the Federal Government used approximately 665.4 trillion Btu of energy for vehicles and equipment, a decrease of 28.8 percent relative to FY 1985. DOD's vehicle and equipment energy consumption decreased 30.7 percent from FY 1985, while the civilian agencies increased consumption by 10.3 percent. Overall, vehicle and equipment consumption decreased 1.4 percent from FY 1996. Federal energy consumption in vehicles and equipment is at its lowest level since Federal agencies began reporting consumption in 1975. This is mainly attributable to decreased operations by the Department of Defense.

Jet fuel consumption accounted for 71.5 percent of all vehicle and equipment energy in FY 1997. In FY 1997 compared to the previous year, jet fuel consumption decreased 7.3 percent from 513.0 trillion Btu to 475.7 trillion Btu.

Agencies have taken many tangible steps to keep the use of vehicle fuels to a minimum. For example, USPS continues to modernize its fleet, adding diesel delivery vans and long-life vehicles to its inventory, both of which are more fuel efficient than the older vehicles they replaced. DOD continues to increase the use of flight simulators, as well as the use of new propulsion technologies in order to lessen the growth of vehicle and equipment fuel consumption.

Increased mission activities accounted for higher levels of operations energy use by some agencies. The Commerce Department's significant increase in consumption during FY 1990 was due primarily to increased miles driven by Census personnel in conducting the 1990 Census. Energy consumption in DOC's vehicles has declined by 70.0 percent in FY 1997 from FY 1990.

Other fluctuations in consumption of vehicle fuels resulted from changes in data collection and reporting procedures. The significant decrease in vehicular fuel consumption compared to FY 1985 reported by the Department of Health and Human Services is the result of data collection difficulties which omitted from their reports fuel consumed by leased vehicles and privately-owned vehicles authorized for Government service after FY 1987. HHS reported no vehicles under the agency's control during FY 1990, FY 1991, and FY 1992. 
TABLE 10

FEDERAL ENERGY CONSUMPTION IN VEHICLE AND EQUIPMENT OPERATIONS

(In Billions of Btu, with Conversions to Millions of Barrels of Oil Equivalent [MBOE], and Petajoules [Joule x $10^{15}$ ])

\begin{tabular}{|c|c|c|c|c|c|c|c|c|c|c|c|c|c|c|}
\hline $\begin{array}{l}\text { CIVILIAN } \\
\text { AGENCY }\end{array}$ & $\begin{array}{c}\text { FY } \\
1985\end{array}$ & $\begin{array}{c}F Y \\
1986\end{array}$ & $\begin{array}{l}\text { FY } \\
1987\end{array}$ & $\begin{array}{c}F Y \\
1988\end{array}$ & $\begin{array}{c}F Y \\
1989\end{array}$ & $\begin{array}{c}\text { FY } \\
1990\end{array}$ & $\begin{array}{c}F Y \\
1991\end{array}$ & $\begin{array}{c}\text { FY } \\
1992\end{array}$ & $\begin{array}{c}\text { FY } \\
1993\end{array}$ & $\begin{array}{c}\text { FY } \\
1994\end{array}$ & $\begin{array}{c}\text { FY } \\
1995\end{array}$ & $\begin{array}{c}F Y \\
1996\end{array}$ & $\begin{array}{c}F Y \\
1997\end{array}$ & $\begin{array}{c}\text { \%CHANGE } \\
85-97\end{array}$ \\
\hline USPS & $11,524.2$ & $11,588.2$ & $11,722.9$ & $11,993.3$ & $12,081.4$ & $12,136.2$ & $12,196.2$ & $12,225.0$ & $12,565.3$ & $13,348.6$ & $14,571.2$ & $14,217.1$ & $16,779.2$ & 45.6 \\
\hline DOT & $11,957.0$ & $10,706.6$ & $11,457.7$ & $11,036.6$ & $11,414.2$ & $12,150.8$ & $12,350.7$ & $8,702.6$ & $10,769.7$ & $12,917.0$ & $12,193.7$ & $12,222.9$ & $12,347.9$ & 3.3 \\
\hline USDA & $4,319.6$ & $3,242.7$ & $3,648.3$ & $4,300.1$ & $4,783.4$ & $4,952.3$ & $5 ; 123.8$ & $4,982.7$ & $4,931.2$ & $5,129.1$ & $4,821.7$ & $4,654.8$ & $3,153.0$ & -27.0 \\
\hline DOJ & $2,064.0$ & $2,141.8$ & $2,195.3$ & $1,983.3$ & $2,152.3$ & $2,097.9$ & $2,124.0$ & $3,675.1$ & $2,835.9$ & $3,451.3$ & $3,181.6$ & $3,693.0$ & $3,149.3$ & 52.6 \\
\hline DOI & $3,053.9$ & $3,105.4$ & $2,967.3$ & $3,097.8$ & $3,075.5$ & $3,352.5$ & $3,208.6$ & $3,819.1$ & $3,507.8$ & $3,970.0$ & $2,782.2$ & $1,347.5$ & $2,943.7$ & -3.6 \\
\hline DOE & $2,946.7$ & $2,888.4$ & $2,759.3$ & $2,729.3$ & $2,717.4$ & $2,520.4$ & $2,559.7$ & $2,078.1$ & $2,241.3$ & $2,085.9$ & $1,841.9$ & $1,561.0$ & $1,971.0$ & -33.1 \\
\hline NASA & $1,972.7$ & $1,828.1$ & $1,510.8$ & $1,550.1$ & $1,649.9$ & $1,736.7$ & $1,864.0$ & $1,875.4$ & $1,798.0$ & $1,734.9$ & $1,757.0$ & $1,539.3$ & $1,622.1$ & -17.8 \\
\hline TRSY & $2,155.0$ & $2,055.1$ & $2,193.3$ & $2,921.9$ & $2,713.2$ & $1,473.2$ & $1,655.7$ & $2,065.2$ & $2,420.9$ & $2,161.8$ & $1,773.4$ & $1,350.9$ & $1,561.4$ & -27.5 \\
\hline VA & 592.8 & 595.5 & 660.0 & 630.1 & 629.4 & 518.3 & 317.4 & 634.9 & 663.9 & 374.4 & 353.6 & 660.7 & $1,199.1$ & 102.3 \\
\hline DOC & $1,010.2$ & $1,059.8$ & $1,008.2$ & $1,228.7$ & $1,534.1$ & $3,100.3$ & $1,315.2$ & 952.5 & 995.7 & 995.2 & 760.6 & 570.1 & 929.1 & -8.0 \\
\hline PCC & 530.4 & 600.0 & 686.2 & 629.5 & 700.3 & 653.7 & 578.6 & 699.6 & 684.9 & 688.4 & 866.7 & 829.7 & 766.8 & 44.6 \\
\hline TVA & 578.5 & 440.6 & 493.8 & 480.4 & 400.8 & 476.6 & 534.7 & 408.8 & 452.4 & 480.3 & 541.7 & 583.8 & 479.5 & -17.1 \\
\hline HHS & 373.3 & 331.9 & 358.4 & 206.2 & 204.3 & 0.0 & 0.0 & 0.0 & 177.3 & 176.3 & 105.5 & 18.6 & 435.0 & 16.5 \\
\hline DOL & 232.2 & 236.7 & 250.1 & 270.4 & 239.0 & 239.0 & 401.9 & 388.7 & 369.1 & 369.6 & 356.9 & 337.7 & 336.2 & 44.8 \\
\hline EPA & 132.2 & 33.0 & 32.5 & 37.7 & 29.4 & 0.0 & 0.0 & 0.0 & 100.7 & 97.8 & 99.5 & 76.3 & 136.8 & 3.5 \\
\hline GSA & 144.1 & 134.0 & 110.7 & 117.6 & 109.8 & 128.1 & 122.6 & 102.9 & 79.6 & 69.9 & 91.3 & 98.8 & 119.9 & -16.8 \\
\hline ST & 14.8 & 16.0 & 29.7 & 37.4 & 38.8 & 34.9 & 0.0 & 0.0 & 7.5 & 0.0 & 0.0 & 0.0 & 44.7 & 202.7 \\
\hline HUD & 0.0 & 0.0 & 0.0 & 0.0 & 0.0 & 0.0 & 32.7 & 33.6 & 31.6 & 30.7 & 25.4 & 25.4 & 28.3 & $N / A$ \\
\hline FCC & 12.4 & 9.6 & 11.7 & 9.3 & 8.6 & 9.1 & 7.2 & 7.5 & 7.2 & 6.6 & 6.6 & 4.8 & 7.1 & -42.8 \\
\hline OTHER ${ }^{*}$ & 39.2 & 51.8 & 42.3 & 42.5 & 67.9 & 69.6 & 27.6 & 113.6 & 106.7 & 105.4 & 119.6 & 116.9 & 140.1 & 257.1 \\
\hline \multicolumn{15}{|c|}{ CIVILIAN AGENCIES } \\
\hline TOTAL & $43,653.1$ & $41,065.1$ & $42,138.3$ & $43,302.0$ & $44,549.5$ & $45,649.7$ & $44,420.7$ & $42,765.2$ & $44,746.7$ & $48,193.3$ & $46,250.1$ & $43,909.3$ & $48,150.2$ & 10.3 \\
\hline DOD & $890,679.9$ & $883,768.6$ & $916,766.0$ & $803,594.2$ & $915,445.1$ & $881,345.1$ & $926,033.6$ & $740,357.2$ & $727,887.1$ & $674,597.5$ & $640,893.4$ & $631,202.0$ & $617,235,4$ & -30.7 \\
\hline \multicolumn{15}{|c|}{ ALL AGENCIES } \\
\hline TOTAL & $934,333.0$ & $924,833.7$ & $958,904.3$ & $846,896.1$ & $959,994.5$ & $926,994.8$ & $970,454.3$ & $783,122.4$ & $772,633.7$ & $722,790.8$ & $687,143.4$ & $675,111.3$ & $665,385.6$ & -28.8 \\
\hline MBOE & 160.4 & 158.8 & 164.6 & 145.4 & 164.8 & 159.1 & 166.6 & 134.4 & 132.6 & 124.1 & 118.0 & 115.9 & 114.2 & \\
\hline Petajoules & 985.7 & 975.7 & $1,011.6$ & 893.4 & $1,012.8$ & 977.9 & $1,023.8$ & 826.2 & 815.1 & 762.5 & 724.9 & 712.2 & 702.0 & \\
\hline
\end{tabular}

*Other includes for certain years the CFTC, CIA, FEMA, HUD, NSF, NRC, OPM, and USIA.

Note: FY 1996 contains estimated data for the following agency: OPM.

Sum of components may not equal total due to independent rounding.

Source: Federal Agency Annual Energy Management Data Reports 
Figure 10

Defense and Civilian Federal Energy Consumption in

Vehicles and Equipment by Fuel Type, FY 1997

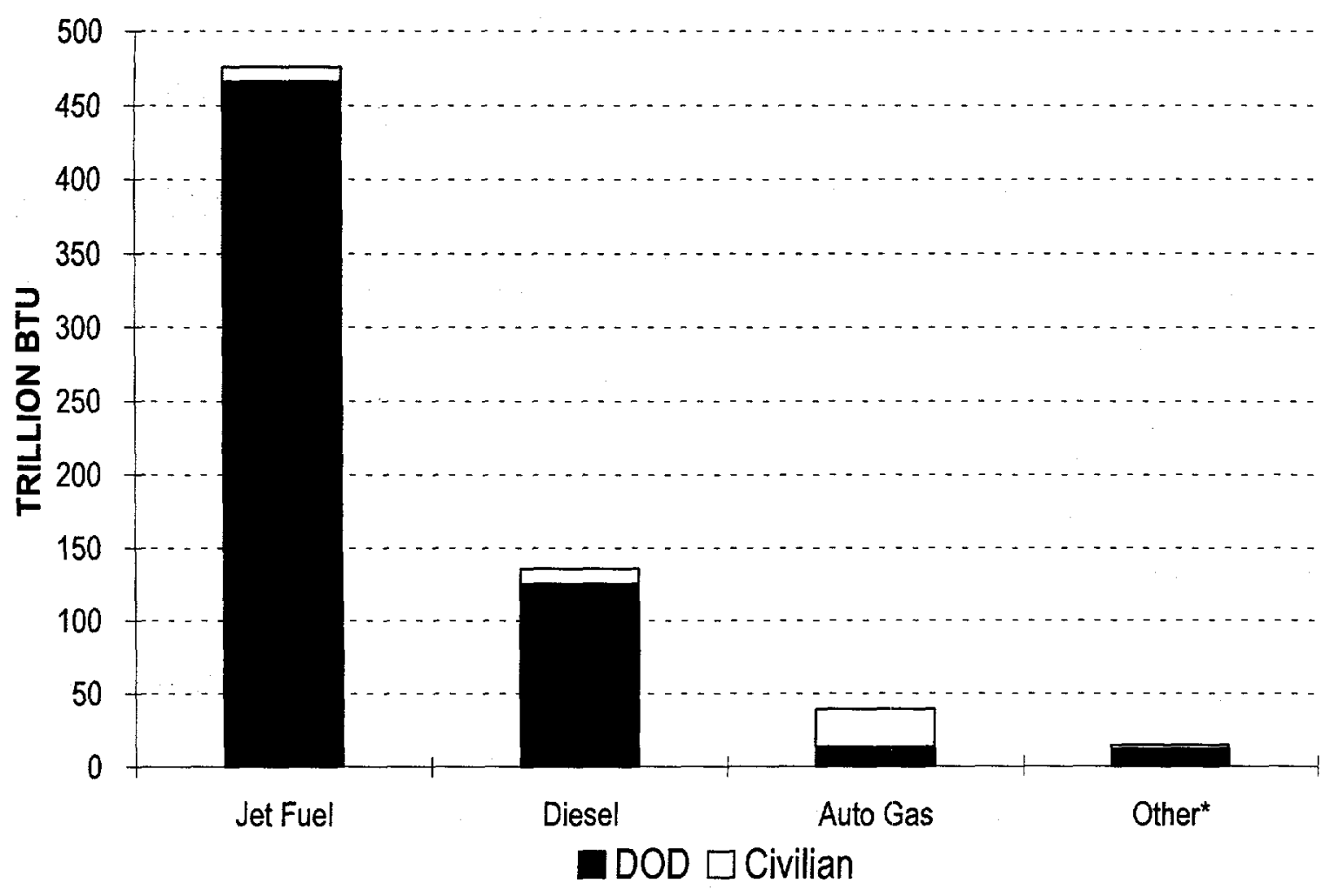

*Other includes navy special, aviation gas, and LPG/propane

Figure 10 depicts the vehicles and equipment fuel mix within DOD and civilian agencies. Jet fuel accounts for 475.7 trillion Btu or 71.5 percent of the total energy usage in the category, with 20.4 percent attributed to diesel and distillate fuel, 5.9 percent to auto gasoline, and 2.2 percent to aviation gasoline, navy special, LPG/propane and other fuels, combined.

As shown in Tables 11-A and 11-B, the Federal Government spent $\$ 4,032.6$ million on vehicles and equipment energy in FY 1997, 15.2 percent more than the FY 1996 expenditure of $\$ 3,499.8$ million constant dollars. In FY 1997, the combined price for all types of vehicles and equipment energy was $\$ 6.06$ per million Btu, up 16.9 percent from FY 1996. The average real cost of gasoline to the Federal Government remained constant from FY 1996 to FY 1997 at $\$ 1.05$ per gallon. The unit cost for diesel/distillate fuel increased 32.8 percent while the unit cost for jet fuel rose 16.4 percent.

When compared to FY 1985 using constant 1997 dollars, energy costs for vehicles and equipment decreased 53.6 percent from $\$ 8,687.9$ million to $\$ 4,032.6$ million in FY 1997. During that same period, the Government's combined cost for vehicles and equipment energy, in constant dollars, fell 34.8 percent from $\$ 9.30$ per million Btu to $\$ 6.06$ per million Btu.

Vehicle and equipment fuel costs in FY 1997 represent 48.9 percent of the Government's total energy costs of $\$ 8.3$ billion. 
TABLE 11-A

DEFENSE AND CIVILIAN FEDERAL COSTS FOR VEHICLE AND EQUIPMENT ENERGY N FY 1997

(In Millions of Dollars)

$\begin{array}{lrrrrrrrr} & \text { AUTOGAS } & \begin{array}{c}\text { DIST. } \\ \text { DIESEL }\end{array} & \begin{array}{c}\text { LPGI } \\ \text { PROPANE }\end{array} & \begin{array}{c}\text { AVIATION } \\ \text { GAS }\end{array} & \text { JET FUEL } & \begin{array}{c}\text { NAVY } \\ \text { SPECIAL }\end{array} & \text { OTHER } & \text { TOTAL } \\ \text { DEFENSE } & 90.089 & 707.494 & 0.000 & 0.000 & 2,797.500 & 0.000 & 41.486 & 3,636.568 \\ \text { CIVILIAN } & 238.823 & 67.792 & 0.162 & 3.707 & 69.256 & 0.000 & 16.290 & 396.030 \\ \text { TOTAL } & 328.912 & 775.286 & 0.162 & 3.707 & 2,866.756 & 0.000 & 57.776 & 4,032.599\end{array}$

AVERAGE COST PER UNIT, BASED ON REPORTS FROM AGENCIES

$\begin{array}{ll}\text { AUTO GAS } & =1.05, \text { GALLON } \\ \text { DISTIDIESEL } & =0.79 ; \text { GALLON } \\ \text { LPG/PROPANE } & =0.83, \text { GALLON } \\ \text { AVIATION GAS } & =1.83, \text { GALLON } \\ \text { JET FUEL } & =0.78, \text { GALLON } \\ \text { NAVY SPECIAL } & =0.00, \text { GALLON } \\ \text { OTHER } & =3.97, \text { MLLION BTU }\end{array}$

DATA AS OF 01/29/99

Note: Sum of components may not equal total due to independent rounding.

Source: Federal Agency Annual Energy Management Data Reports 
TABLE 11-B

CONSUMPTION AND COSTS OF VEHICLE AND EQUIPMENT

ENERGY BY FUEL TYPE IN FY 1997, FY 1996, AND FY 1985

(Constant 1997 Dollars)

\begin{tabular}{|c|c|c|c|}
\hline ENERGY TYPE & $\begin{array}{c}\text { BILLIONS OF } \\
\text { BTU }\end{array}$ & $\begin{array}{l}\text { COST PER } \\
\text { MMBTU }\end{array}$ & $\begin{array}{l}\text { COST (IN MILLIONS } \\
\text { OF DOLLARS) }\end{array}$ \\
\hline \multicolumn{4}{|l|}{ FY 1997} \\
\hline AUTO GASOLINE & $39,047.5$ & 8.4234 & 328.912 \\
\hline DIST/DIESEL & $135,846.0$ & 5.7071 & 775.286 \\
\hline LPGIPROPANE & 18.7 & 8.6408 & 0.162 \\
\hline AVIATION GASOLINE & 253.7 & 14.6158 & 3.707 \\
\hline JET FUEL & $475,672.5$ & 6.0267 & $2,866.756$ \\
\hline NAVY SPECIAL & 0.0 & 0.0000 & 0.000 \\
\hline OTHER & $14,547.2$ & 3.9716 & 57.776 \\
\hline TOTAL & $665,385.6$ & & $4,032.599$ \\
\hline \multicolumn{4}{|c|}{ COMBINED COST PER MMBTU $=\$ 6.061$} \\
\hline \multicolumn{4}{|l|}{ FY 1996} \\
\hline AUTO GASOLINE & $27,562.9$ & 8.3950 & 231.390 \\
\hline DIST/DIESEL. & $115,618.7$ & 4.2990 & 497.039 \\
\hline LPG/PROPANE & 22.1 & 8.6607 & 0.191 \\
\hline AVIATION GASOLINE & 241.4 & 14.3507 & 3.464 \\
\hline JET FUEL & $512,969.1$ & 5.1723 & $2,653.277$ \\
\hline NAVY SPECIAL & 0.0 & 0.0000 & 0.000 \\
\hline OTHER & $18,697.1$ & 6.1206 & 114.437 \\
\hline TOTAL & $675,111.3$ & & $3,499.797$ \\
\hline \multicolumn{4}{|c|}{ COMBINED COST PER MMBTU $=\$ 5.184$} \\
\hline \multicolumn{4}{|l|}{ FY 1985} \\
\hline AUTO GASOLINE & $50,481.7$ & 10.8311 & 546.772 \\
\hline DIST/DIESEL & $169,217.9$ & 8.6437 & $1,462.675$ \\
\hline LPG/PROPANE & 149.3 & 10.0463 & 1.500 \\
\hline AVIATION GASOLINE & $1,882.3$ & 16.0000 & 30.116 \\
\hline JET FUEL & $705,675.5$ & 9.3405 & $6,591,345$ \\
\hline NAVY SPECIAL & $6,687.7$ & 8.0160 & 53.609 \\
\hline OTHER & 238.6 & 7.7277 & 1.844 \\
\hline TOTAL & $934,333.0$ & & $8,687.862$ \\
\hline
\end{tabular}

COMBINED COST PER MMBTU $=\$ 9.298$

DATA AS OF 01/29/99

Note: Sum of components may not equal total due to independent rounding.

Source: $\quad$ Federal Agency Annual Energy Management Data Reports 


\section{B. Gasoline and Diesel Consumption}

Section 10 of Executive Order 12759 established an energy-efficiency goal for Federal vehicles to reduce gasoline and diesel consumption by at least ten percent by FY 1995 in comparison to FY 1991. Although the goal period for this requirement is past, this report will continue to track progress against the FY 1991 base year.

Table 12 shows that of the agencies reporting gasoline consumption, the level of consumption overall increased 14.4 percent from 273.2 million gallons in FY 1991 to 312.4 million gallons in FY 1997.

Of the agencies reporting consumption of diesel fuel, the overall level of consumption decreased 12.6 percent from 1,120.1 million gallons in FY 1991 to 979.4 million gallons in FY 1997. DOD's 15.8 percent decrease in diesel consumption is the main contributing factor in this decrease. The high level of diesel consumption by DOD during FY 1991 is attributed to Desert Shield/Desert Storm operations. Diesel consumption data may include other types of off-road vehicles and equipment, in addition to on-road passenger cars and trucks. 
TABLE 12

FEDERAL AGENCY PROGRESS TOWARD THE GOALS OF SECTION 10 OF EXECUTIVE ORDER 12759, FY 1991 and FY 1997

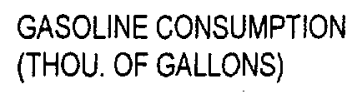

DOC

TVA

DOL

NASA

EPA

GSA

ST

PCC

HUD

SSA

OPM

CIA

FEMA

USIA

SBA

NSF

FCC

NRC

RRB

FTC

SSS

NARA

EEOC

TOTAL

1991

$72,152.0$

$37,949.6$

$17,834.8$

$14,260.1$

$9,439.7$

$2,094.0$

$5,500.8$

$5,666.7$

0.0

$2,525.0$

$2,234.0$

$3,215.0$

$2,576.0$

0.0

980.5

0.0

335.9

261.5

0.0

0.0

0.0

90.1

0.0

0.0

55.8

35.5

0.0

0.0

0.0

0.0

0.0
DIESEL CONSUMPTION

(THOU. OF GALLONS)

$\begin{array}{rc}1997 & \% \text { CHANGE } \\ & \\ 108,026.0 & 12.6 \\ 01,718.4 & 41.0 \\ 25,060.1 & -34.0 \\ 17,050.4 & -4.4 \\ 14,588.2 & 2.3 \\ 9,563.9 & 1.3 \\ 7,881.3 & 276.4 \\ 6,514.0 & 18.4 \\ 5,322.5 & -6.1 \\ 3,168.3 & \text { N/A } \\ 2,798.9 & 10.8 \\ 2,612.9 & 17.0 \\ 2,282.4 & -29.0 \\ 1,997.2 & -22.5 \\ 1,044.3 & \text { N/A } \\ 950.1 & -3.1 \\ 325.4 & \text { N/A } \\ 284.4 & -15.3 \\ 225.0 & -14.0 \\ 174.5 & 0.0 \\ 166.3 & 0.0 \\ 137.9 & 0.0 \\ 133.8 & 0.0 \\ 103.7 & 15.1 \\ 93.1 & \text { N/A } \\ 61.5 & \text { N/A } \\ 56.9 & 2.0 \\ 28.4 & -19.9 \\ 7.1 & \text { N/A } \\ 1.4 & \text { N/A } \\ 1.2 & \text { N/A } \\ 0.3 & \text { N/A } \\ 0.2 & \text { N/A }\end{array}$

AGENCY 1991

$\begin{array}{lr}\text { DOD } & 1,073,084.0 \\ \text { DOT }^{1} & 94.8\end{array}$

USPS $\quad 22,907.0$

PCC $\quad 3,869.0$

DOE $\quad 6,067.8$

DOC $\quad 6,637.1$

DOI $\quad 1,514.2$

VA $\quad 401.0$

TVA

NASA

$1,791.0$

644.0

775.2

DOL

HHS

TRSY

USIA

USDA

CIA

EPA

SSA

ST

FEMA

GSA

NSF

SBA

HUD

NRC

OPM

SSS

FCC

TOTAL $\quad 1,120,133.0$

14.4
1997 \%CHANGE

$\begin{array}{rc}903,906.0 & -15.8 \\ 27,587.2 & 29,200.4 \\ 26,638.7 & 16.3 \\ 5,272.1 & 36.3 \\ 4,122.2 & -32.1 \\ 3,425.5 & -48.4 \\ 3,361.8 & 122.0 \\ 1,542.6 & 284.7 \\ 1,004.7 & -43.9 \\ 833.7 & 29.5 \\ 574.3 & -25.9 \\ 366.6 & \mathrm{~N} / \mathrm{A} \\ 280.8 & \mathrm{~N} / \mathrm{A} \\ 177.2 & 186.7 \\ 94.0 & 15.4 \\ 67.9 & -96.9 \\ 40.0 & \mathrm{~N} / \mathrm{A} \\ 33.8 & \mathrm{~N} / \mathrm{A} \\ 32.3 & \mathrm{~N} / \mathrm{A} \\ 29.2 & \mathrm{~N} / \mathrm{A} \\ 17.0 & \mathrm{~N} / \mathrm{A} \\ 8.4 & \mathrm{~N} / \mathrm{A} \\ 3.1 & \mathrm{~N} / \mathrm{A} \\ 1.4 & \mathrm{~N} / \mathrm{A} \\ 1.0 & \mathrm{~N} / \mathrm{A} \\ 0.7 & 41.3 \\ 0.5 & \mathrm{~N} / \mathrm{A} \\ 0.5 & \mathrm{~N} / \mathrm{A} \\ 0.0 & -100.0 \\ & \\ 979,423.1 & -12.6 \\ & \\ \text { DATA AS OF } 01 / 29 / 99\end{array}$

${ }^{1}$ DOT reported diesel fuel used in U.S. Coast Guard vessels under this category.

Note: FY 1996 contains estimated data for the following agencies: FCC and OPM.

Sum of components may not equal total due to independent rounding.

Source: Federal Agency Annual Energy Management Data Reports 


\section{Alternative Fuel Vehicles}

An alternative fuel vehicle (AFV) can be manufactured as an AFV or converted to an AFV as either a bi-fuel, flexible fuel, or dedicated vehicle. A bi-fuel vehicle has the ability to operate on either an alternative fuel or gasoline, whereas a flexible fuel vehicle has the ability to operate on a mixture of alternative fuel and petroleum-based fuels. Dedicated vehicles are designed to operate only on alternative fuel. The alternative fuels currently used by Federal agencies are: M-85 (85 percent methanol, 15 percent gasoline), E-85 ( 85 percent ethanol, 15 percent gasoline), CNG (compressed natural gas), LNG (liquified natural gas), LPG (liquified petroleum gas), and electricity.

Sections 301 to 311 of Title III of EPACT contain provisions affecting Federal fleets. These sections of EPACT expand and confirm the activities and goals of section 11 of Executive Order 12759. Executive Order 12759, section 11, requires that the Federal Government acquire the maximum number practicable of AFVs. To meet the requirements of Executive Order 12759, each Federal agency has developed a five-year plan for introducing AFVs into its fleet. Section 303 of EPACT, 42 U.S.C. $\S 13212$, mandates the fleet requirements for new acquisitions to the Federal fleet listed in the first column of the following table. With the Executive Order 12844 of April 21, 1993, the President has established even more aggressive goals for increased AFV usage. Under this Executive Order, each agency should exceed EPACT requirements by 50 percent for FY 1993 through 1995. The Federal fleet targets under this order are listed below.

AFV Requirements for New Acquisitions in Federal Fleet

\begin{tabular}{||l|c|c||}
\hline Fiscal Year & EPACT & Executive Order 12844 \\
\hline FY 1993 & 5,000 & 7,500 \\
\hline FY 1994 & 7,500 & 11,250 \\
\hline FY 1995 & 10,000 & 15,000 \\
\hline FY 1996 & $7,150^{15}$ & N/A \\
\hline FY 1997 & 9,500 & N/A \\
\hline
\end{tabular}

Through its Interagency Fleet Management System (IFMS) and the Automotive Center, the General Services Administration plays a key role in the implementation of AFV legislation. GSA provides vehicles and support services to other Federal agencies through the IFMS. The IFMS accounts for approximately 25 percent of the total Federally-owned inventory of 550,000 vehicles and 75 percent of the annual Federal light duty vehicle acquisitions. During FY 1996, the latest year for which data was provided, GSA's Automotive Center procured 1,541 AFVs; the types and models of these are shown below.

\footnotetext{
${ }^{15}$ These figures based on GSA estimates of approximately 28,000 annual vehicle acquisitions by EPACTcovered Federal fleets. Section 303 of the EPACT states that 25 percent of all new acquisitions in 1996 and 33 percent in 1997 must be AFVs.
} 
FY 1996 AFV Purchases by GSA's Automotive Center

\begin{tabular}{||l|l|c||}
\hline \multicolumn{1}{|c|}{ Make and Model } & \multicolumn{1}{|c|}{ Fuel } & $\begin{array}{c}\text { Number } \\
\text { Purchased }\end{array}$ \\
\hline Ford Taurus Mid-Size Sedan & M85 Flexible Fuel & 9 \\
\hline Ford Taurus Mid-Size Sedan & E85 Flexible Fuel & 1,132 \\
\hline Chrysler Eight-Passenger Van & CNG Dedicated & 10 \\
\hline Various Makes and Models & CNG Bi-Fuel & 249 \\
\hline $\begin{array}{l}\text { Chrysler Minivan/ } \\
\text { General Motors S10 Pickup }\end{array}$ & Electricity & 141 \\
\hline
\end{tabular}

The GSA Automotive Center is the central source for establishing Federal contracts with manufacturers for the purchase of vehicles. The Center handles the acquisition of all light and medium duty vehicles for all Federal agencies, including the IFMS. The Center, as part of its effort under the Alternative Motor Fuels Act (AMFA), developed specifications and procurement descriptions for the acquisition of AFVs with original equipment manufacturers (OEM).

The U.S. Postal Service continues to operate the largest CNG fleet in the country. Since 1989, more than 7,000 vehicles have been converted to compressed natural gas. Most USPS AFVs are dual-fueled (gasoline and $\mathrm{CNG}$ ) and it plans to continue converting more vehicles to dual-fuel CNG. USPS has also been investigating the use of electric vehicles in joint efforts with the Department of Energy and under contract with Ford Motor Company and General Motors Corporation-Hughes. It plans to convert an additional 20 vehicles from gasoline to electric for delivery in 1997. The USPS also is testing a small group of ethanol powered vehicles. Its engineering staff, in cooperation with other Federal agencies and private industry, continues to evaluate electric and alternative fuel technologies as they become available.

Section 308 of Title III of EPACT, 42 U.S.C. $\S 13217$, requires agencies to measure the aggregate percentage of alternative fuel use in dual-fueled vehicles in their fleets. In an effort to better fulfill this reporting requirement, vehicle fleet managers and representatives from DOE, GSA, and other agencies conducted coordinating meetings during FY 1996 on this issue. These meetings resulted in a revised GSA Agency Report of Motor Vehicle Data (form SF-82) for collecting acquisition, fuel consumption, and fuel cost data for non-tactical motor vehicles. The revised SF-82 was distributed by GSA to agency fleet managers beginning in FY 1997. GSA compiled this data for FY 1997, including alternative fuel consumption data reported under Sections 303 and 308 of EPACT, and forwarded this information to DOE for inclusion in the Annual Report to Congress.

As shown in Table 13, the Federal Government consumed 529.0 billion Btu of alternative fuels in non-tactical vehicles during FY 1997. This is equivalent to 4.2 million gallons of gasoline. Alternative fuel consumption comprises 0.1 percent of the energy used in all Government vehicles and equipment. When compared with Federal consumption of automobile gasoline, alternative fuels comprise 1.4 percent of this energy use. 
TABLE 13

FEDERAL AGENCY CONSUMPTION OF ALTERNATIVE FUELS IN NON-TACTICAL VEHICLES, FY 1997

(In Billions of Btu)

\begin{tabular}{|c|c|c|c|c|c|c|}
\hline Agency & CNG & E-85 & $M-85$ & Electricity & LPG/Propane & Total \\
\hline U.S. Postal Service & 369.6 & 0.0 & 0.0 & 0.0 & 0.0 & 369.6 \\
\hline U.S. Air Force & 95.2 & 0.6 & 2.2 & 5.0 & 0.0 & 102.9 \\
\hline Department of Transportation & 2.4 & 9.6 & 5.8 & 0.0 & 0.0 & 17.8 \\
\hline U.S. Marine Corps & 12.4 & 0.0 & 1.0 & 0.0 & 0.0 & 13.4 \\
\hline Department of Agriculture & 1.1 & 4.9 & 1.6 & 0.0 & 4.6 & 12.2 \\
\hline Department of Energy & 5.9 & 0.0 & 0.0 & 0.0 & 0.0 & 5.9 \\
\hline U.S. Army Corps of Engineers & 0.3 & 0.0 & 0.5 & 1.1 & 0.0 & 2.0 \\
\hline U.S. Army & 0.2 & 0.1 & 0.0 & 0.0 & 0.0 & 0.3 \\
\hline Department of Justice & 0.0 & 0.2 & 0.0 & 0.0 & 0.0 & 0.2 \\
\hline NASA & 4.5 & 0.0 & 0.0 & 0.0 & 0.0 & 4.5 \\
\hline Total & 491.7 & 15.5 & 11.1 & 6.1 & 4.6 & 529.0 \\
\hline
\end{tabular}

During FY 1997, compressed natural gas (CNG) comprised the largest portion of alternative fuel consumption with 92.9 percent. An ethanol and gasoline blend (E-85) is the second most consumed alternative fuel with 3.0 percent.

The U.S. Postal Service uses the majority of alternative fuels, consuming 69.9 percent of the total alternative fuel used by the Federal Government. The Postal Service's consumption of 369.6 billion Btu of CNG comprises 2.2 percent of the agency's total fuel consumption.

The U.S. Air Force consumes the highest fleet report ratio of alternative fuel to petroleum-based fuels with 3.8 percent. Although 92.5 percent of the agency's alternative fuel consumption is $\mathrm{CNG}$, the Air Force operates one of the world's largest fleets of electric vehicles.

The Department of Energy has made efforts to provide the private and public sector with information on issues concerning AFVs. An Alternative Fuels Hotline (1-800-423-1DOE) was established in June 1992 to provide callers from Federal agencies, industry and the public with answers to questions on AFVs. By calling the toll free number, callers can request information on AFVs. In 1997, 6,261 calls were received and 77,425 documents were distributed. Many callers had questions concerning the purchase of and conversion to AFVs, EPACT and Clean Air Act requirements, funding and tax incentives, and training and safety issues.

The Alternative Fuels Data Center (AFDC), which is located at the National Renewable Energy Laboratory (NREL) in Golden, Colorado, may be accessed by the public on the Internet at http://www.afdc.nrel.gov. The site was accessed more than 655,000 times in 1997, indicating a growing public interest in alternative fuels. The AFDC is the central repository for data from DOE's alternative fuel vehicle demonstration programs. The AFDC stores data on demonstration programs that receive funding support authorized by the AMFA of 1988 . Information collected and provided by the AFDC includes: 
- data on 600 government fleet vehicles;

- refueling site information for CNG, LPG, Ethanol, and Methanol;

- information on emissions, mileage, fuel economy;

- information on emissions, for flexible fuel vehicles running on alcohol fuels and gasoline;

- repair and maintenance logs for alternative fuel fleet vehicles;

- heavy duty and transit bus data on performance, emissions, fuel economy, and mileage;

- data on the Clean Fleet Program - run by Federal Express and South Coast Air Quality Management District (a controlled comparative study of operating data from gasoline vehicles and different types of alterative fuels).

Federal efforts to expand deployment of AFVs were boosted by the Clean Cities Program during FY 1997. The Clean Cities Program, initiated by the DOE in September 1993, is a voluntary program designed to increase fleet vehicle alternative fuel use by encouraging partnerships between fuel suppliers, vehicle manufacturers, fleet managers, and Federal, State, and local government agencies. DOE supports Clean Cities participants through the placement of Federal vehicles and by maintaining a national hotline and a support staff member at each of its ten regional support offices, which provide local assistance concerning federal and State requirements for AFV acquisitions and conversions and assist local Clean Cities with their alternative fuels market development. In 1997, seven new cities were awarded the Clean Cities designation, for a total of 60 Clean Cities. DOE has established a number to handle inquiries from cities interested in joining the program: 1-800-CCITIES. The program's Internet address, www.ccities.doe.gov, was accessed 107,646 times during FY 1997. 


\section{FEDERAL AGENCY ENERGY MANAGEMENT ACTIVITIES}

\section{DEPARTMENT OF AGRICULTURE (USDA)}

Energy Efficiency Performance and Implementation Strategies In FY 1997, the United States Department of Agriculture reported a decrease of 27.2 percent in Btu per gross square foot compared to FY 1985.

\section{USDA Performance Toward Buildings Energy Reduction Goals}

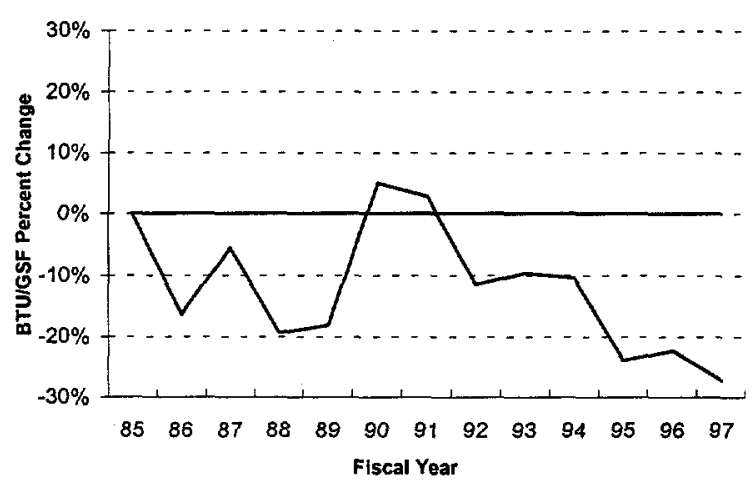

USDA Buildings Energy Use and Costs, FY97

$\begin{array}{lrr} & \text { BBtu } & \text { \$(Thou.) } \\ \text { Electricity } & 1,109.5 & 20,663.0 \\ \text { Fuel Oil } & 66.9 & 483.0 \\ \text { Natural Gas } & 448.8 & 2,054.7 \\ \text { LPG/Propane } & 205.3 & 1,291.0 \\ \text { Coal } & 0.6 & 2.9 \\ \text { Purchased Steam } & 109.3 & 1,146.4 \\ \text { Other } & 55.6 & 1.4 \\ & & \\ \text { Total } & 1,996.0 & 25,642.4\end{array}$

The USDA Energy Management Plan delineates the Department's strategy to achieve the goals of Executive Order 12902. Components of the strategy include increasing occupant awareness, maintaining building envelope and systems, implementing no- and low-cost energy conservation actions, and using energy-saving operation and maintenance techniques.

USDA is a highly decentralized department comprised of about 30 agencies with an extensive nationwide field structure. Each agency has its own field system and operates its facilities independently and in cooperation with its own clientele group.
Following are details of individual agencies' energy conservation improvements in FY 1997:

- Office of Operations (OO). The Washington Area Service Center (WASC) undertook several projects, including HVAC upgrades in the Whitten and South buildings, a steam system survey and repairs, light sensor replacements, hot water system upgrades, and insulation upgrades. The WASC office complex in Beltsville, Maryland, has been designed to incorporate passive solar features.

- Marketing and Regulatory Programs (MRP). The National Veterinary Services Laboratory installed a new energy-efficient chiller; the New York Animal Import Center converted its oil fuel incinerator to natural gas and an HVAC system from electricity to natural gas; the Pocatello Supply Depot converted a steam heating system to natural gas; and the Wildlife Services Predator Research Building upgraded $\mathrm{a}$ boiler and its air conditioning system.

- Agricultural Research Service (ARS). As part of the FY 1997 repair, maintenance, and modernization program effort, ARS invested more than $\$ 2.2$ million in building energy conservation and efficiency projects at more than 20 locations. The projects included HVAC upgrades, energy audits, boiler improvements, lighting retrofits, insulation upgrades, and chiller replacements.

- The Forest Service undertook several projects during FY 1997. These included boiler replacements, insulation improvements, electrical system upgrades, HVAC upgrades, and energy retrofits. Several more projects around the country are scheduled to be completed in FY 1998. The Forest Service continued in its relationship with DOE's Sandia Laboratory for the development of photovoltaic projects. Fourteen solar and wind energy projects were implemented during FY 1997, the majority generating energy to power ranger stations or water pumps.

- The Farm Service Agency, USDA's major lease holder, reported the addition of an alternate energy award factor in its Solicitation for Offers which rewards offers for potential leased space that use alternative energy sources like solar, wind, geothermal, or biomass. 
Energy Showcase Facilities

The WASC office complex in Beltsville, Maryland, has been designated a showcase. The new facility will include passive solar features, low-emissivity windows, building overhangs, photo sensors, and beneficial landscaping. The Whitten and South Buildings at the headquarters facility were also designated as showcases. Features include energy-efficient lighting, occupancy sensors, a chiller plant with an ice storage system that shifts electric load to off-peak hours, and a solar hot water heating system.

The ARS Southern Plains Area designated the Children's Nutrition Research Center in Houston, Texas, to highlight energy efficiency and water conservation measures. The Horticultural Research Laboratory in Fort Pierce, Florida, and the San Joaquin Valley Agricultural Center in Parlier, California, are ARS's new showcases.

\section{Training}

During FY 1997, the MRP energy manager attended one GSA energy efficiency workshop, the Farm Service Agency energy coordinator received 24 hours of energy training, Forest Service personnel received energy training, 11 ARS personnel attended seminars or courses, and three Office of Procurement and Property Management personnel attended various energy management courses.

\section{Funding}

Funds for facility energy efficiency improvements are typically included in repair and alterations or operations and maintenance accounts. Energy improvements are incorporated into building maintenance and alteration activities, making it difficult to specifically identify exact amounts requested or appropriated for energy efficiency projects.

The Office of Operations funded energy improvements to the amount of $\$ 347,450$ in FY 1997. MRP spent $\$ 258,597$ on its chiller replacement and just over $\$ 1$ million on other projects. ARS invested \$2.2 million in improvements. The Forest Service does not request separate funding for energy projects and does not require fiscal accounting to track this information.

\section{Energy Savings Performance Contracts}

To date, USDA has not entered into any energy savings performance contracts with energy service companies or utilities. Potential projects under investigation include:

- Forest Products Laboratory (Forest Service) in Madison, Wisconsin, has potential for a lighting retrofit ESPC: Potential savings are 10 to 15 percent of current consumption rates and between $\$ 60,000$ and $\$ 70,000$ per year.

- Forest Service is expecting proposals for ESPCs at the Science Research Laboratory in Corvallis, Oregon and the Aerial Fire Depot in Missoula, Montana. The latter project is with Montana Power under a GSA area wide contract.

- Plum Island Animal Disease Center (ARS) in Greenport, New York, is in the planning stages of an ESPC for primary and secondary chilled water loops, lighting, power generators, and HVAC systems.

- The National Agricultural Library (ARS) in Beltsville, Maryland, has been selected as a pilot site for DOE's Mid-Atlantic Regional Super ESPC when it is awarded.

- The National Animal Disease Center (ARS) in Ames, Iowa, has been selected as a pilot site for the Midwest Regional Super ESPC.

\section{Vehicles}

The Department's Agriculture Property Management Regulations instruct agencies to implement vehicle sharing programs with co-located and closely situated agencies and activities in the field. The objectives of this program are to maximize vehicle utilization and to reduce associated cost and fuel consumption through vehicle pooling and sharing. The regulations also require operators to perform routine energy-saving tasks: inspect vehicles annually, follow the manufacturer's recommended maintenance schedule, check tire inflations, and obey posted speed limits.

\section{Environmental Activities}

WASC, ARS, and the Forest Service all are making progress in the procurement of environmentally-sound, energy-efficient products and those products that contain a high percentage of recovered materials.

\section{Energy Management Contact}

Ms. Sharon Holcombe

Acting Chief, Energy and Environment Staff

Procurement and Property Management

U.S. Department of Agriculture

14th and Independence Avenue, SW

Washington, DC 20250

Phone: 202-720-3820

Fax: 202-690-1209 


\section{DEPARTMENT OF COMMERCE}

\section{Energy Efficiency Performance and Implementation Strategies}

In FY 1997, the Department of Commerce reported a decrease in buildings energy consumption of 32.1 percent in Btu per gross square foot compared to FY 1985.

\section{DOC Performance Toward Buildings Energy Reduction Goals}

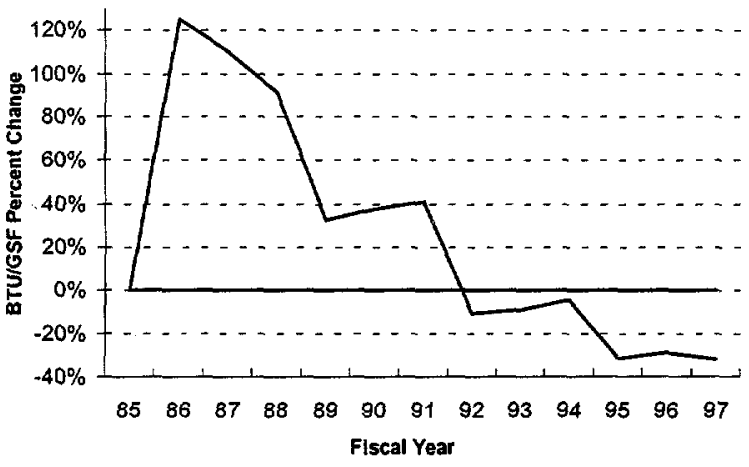

Commerce Buildings Energy Use and Costs, FY97

$\begin{array}{lrr} & \text { BBtu } & \text { \$(Thou.) } \\ \text { Electricity } & 347.4 & 6,935.1 \\ \text { Fuel Oil } & 8.5 & 61.7 \\ \text { Natural Gas } & 68.4 & 345.2 \\ \text { Propane } & 0.8 & 7.5 \\ \text { Purchased Steam } & 32.0 & 465.0 \\ & & \\ \text { Total } & 457.2 & 7,814.5\end{array}$

DOC's comprehensive Strategic Implementation Plan provides guidance for agencies and bureaus; reporting requirements; list of facility energy supervisors; and a motor vehicle fuel reduction plan. The Plan also includes individual conservation plans for the Herbert C. Hoover Building; National Oceanic and Atmospheric Administration; National Institute of Standards and Technology; and the Bureau of the Census.

FY 1997 activities of Commerce Department Agencies include the following:

- The National Institute of Standards and Technology (NIST). NIST facilities are defined as energy intensive due to the nature of the laboratory operations and required environmental conditions. However, NIST activities include efforts to meet energy and water conservation goals. NIST contin- ues to improve the Chilled Water System Master Plan for its campus. These improvements include the recent addition of the variable speed pumping system. A project for two additional boilers includes upgrading the efficiency of the four existing boilers.

- Bureau of the Census. The Charlotte Computer Center is also designated an energy intensive facility. The Jeffersonville Federal Center (JFC) is working with the Public Service of Indiana to implement cost-effective projects identified through an energy audit. JFC has completed measures with a three year payback.

- National Oceanic and Atmospheric Administration (NOAA). The Atlantic Marine Center conducted a study of its HVAC systems during FY 1997 with the goal of upgrading or replacing the existing systems into one cost-effective, energy-efficient system. Problem areas identified included nonfunctional valves and air controls to disconnected ducts blowing air into the overhead.

The NOAA Headquarters in Silver Spring, Maryland consists of three leased, all-electric buildings. During FY 1997, these buildings began an energy and water audit sponsored by DOE/FEMP's SAVEnergy Program. The audit started in July 1997 and site evaluation is now in progress.

DOC is also funding energy audits via the SAVEnergy Program at Weather Service Offices in Ewa Beach, Oahu, and Pago Pago; and the Pacific Tsunami Warning Center (PTWC) in Honolulu.

\section{Energy Showcase Facilities}

The Herbert C. Hoover Building has been designated an energy showcase and has identified eight major projects at an estimated cost of $\$ 3$ million and savings of $\$ 745,000$ annually. Commerce is working with GSA to directly fund a chiller replacement project and to implement water conservation projects that save more than 50 million gallons per year.

NOAA designated the Kihei Whale Sanctuary in Kihei Maui, Hawaii, as its showcase. At the end of FY 1997 , the Sanctuary was placed under contract for the Capital Improvement Program (CIP) and security renovation. Projects include conversion to energy-efficient lighting, photovoltaic security lighting, and solar water heaters. Maui Electric Company is contributing $\$ 2,000$ in copayment. 


\section{Training}

DOC managers attend numerous training workshops in an ongoing effort to stay current with Federal energy requirements and new conservation technologies and methodologies.

\section{Energy Savings Performance Contracts}

The Western Regional Center (WRC) is working with DOE to use its Super ESPC regional contact to implement energy cost savings projects. The WRC was the third agency to be contracted for energy efficiency improvements. The proposed projects include:

- Upgrading existing HVAC units on the roofs of two buildings, and

- Retrofitting fluorescent lighting fixtures.

WRC is considering the Super ESPC to fund its solar/fuel cell projects, in support of the President's Million Solar Roofs Initiative, for the Pacific WSO and PTWC. The project could include photovoltaics for total daytime electrical power and fuel cells for nighttime power. DOE will provide feasibility study, design, and construction assistance.

\section{Utility Partnerships}

NOAA is working with utility companies where services and rebates are available. Through the "Early Chiller Retirement" program offered by Potomac Electric Power Company, NOAA was part of a third party agreement along with the lessor. NOAA projects include LED exit lighting, efficient fluorescent lights,; and occupancy sensors in offices and enclosed areas. The project cost of $\$ 20,000$ for retrofitting the exit lights in two buildings included a rebate of $\$ 8,000$ and resulted in a simple payback of less than a year.

\section{Environmental Activities}

The Commerce Department is a signatory to the Energy Efficiency and Resource Conservation Challenge.

DOC cosponsored the World Energy and Environmental Congress/Environmental Technology Conference (WEEC/ETE) hosted by the Association of Energy Engineers. Over 5,000 professionals from 48 states and 16 countries participated. WEEC/ETE was selected by DOC as an official Foreign Buyer Program in support of the export potential of the industry it serves.

\author{
Energy Management Contact \\ Mr. James Woods \\ Energy Manager \\ Office of Federal Property Programs \\ U.S. Department of Commerce \\ Herbert C. Hoover Building, Room 1329 \\ $14^{\text {th }}$ and Constitution Avenue, NW \\ Washington, DC 20230 \\ Phone: 202-482-0885 \\ Fax: 202-482-1969
}




\section{DEPARTMENT OF DEFENSE (DOD)}

\section{Energy Efficiency Performance and Implementation Strategies}

In FY 1997, the Department of Defense reported a decrease in its buildings and facilities energy of 17.2 percent in Btu per gross square foot compared to FY 1985.

\section{DOD Performance Toward Buildings Energy Reduction Goals}

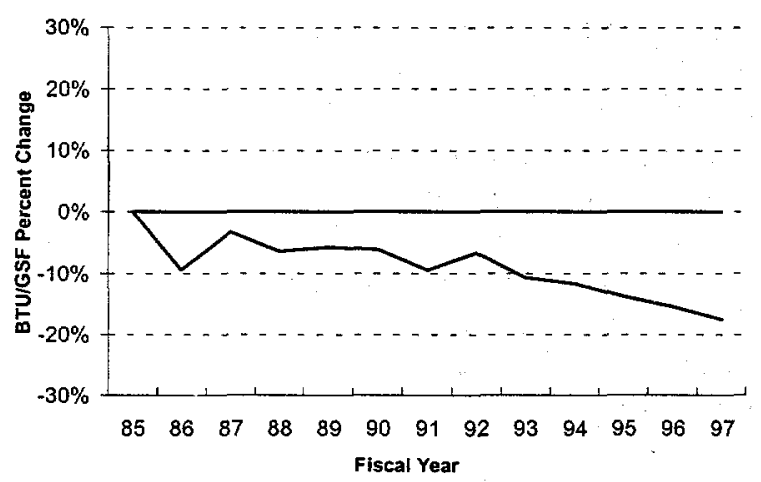

DOD Buildings Energy Use and Costs, FY97

$\begin{array}{lrr} & \text { BBtu } & \text { \$(Thou.) } \\ \text { Electricity } & 85,772.7 & 1,467,868.0 \\ \text { Fuel Oil } & 33,592.6 & 162,963.0 \\ \text { Natural Gas } & 79,901.9 & 317,292.0 \\ \text { Propane } & 1,621.8 & 15,459.0 \\ \text { Coal } & 15,137.0 & 34,336.0 \\ \text { Purchased Steam } & 10,350.0 & 159,713.0 \\ \text { Other } & 694.0 & 748.0 \\ & & \\ \text { Total } & 227,070.0 & 2,158,379.0\end{array}$

DOD continues to emphasize good energy stewardship in operations and management by developing and implementing energy conservation practices and installation of energy-efficient equipment.

The Army gives major commands and installations the flexibility to run their own unique energy programs. The primary objectives of the Army are to improve energy efficiency and eliminate energy waste by investing in energy-efficient technologies and in energy monitoring and control systems (EMCS).

\section{Surveys and Audits}

During FY 1997, the Army completed $\$ 1.7$ million of lighting retrofit work with a total net discounted savings of nearly $\$ 5$ million and an average simple payback of
4.2 years and an overall savings to investment ratio (SIR) of 2.84 .

During FY 1997, the Navy published technical guidance on numerous low-cost/no-cost maintenance actions to increase energy efficiency. The Navy is pursuing an aggressive campaign to heighten energy awareness and increase the training of all personnel involved in energy management.

Marine Corps installation managers continue to provide a key link to effective operation and maintenance procedures that affect energy conservation. There is a new emphasis on predictive maintenance of energy systems and the use of computerized programs to make this effort even more effective. Since Headquarters Marine Corps completed development of an artificial intelligence demonstration program at the Marine Corps Air Ground Combat Center at Twentynine Palms, California, the continued operation and validation has met the original efficiency estimates for the central heating plant. This project provides central heating plant operators real-time efficiency monitoring of the central plant and diagnostics of efficiency degradation.

Numerous efforts are under way in the Air Force to reduce consumption through review of operation and maintenance procedures. Examples of operational enhancements include EMCS to control HVAC operating hours, metering to identify high energy users, rescheduling work loads, establishing no-heat/no-cool periods, and instituting holiday shutdowns.

Improved oversight at Defense Commissary Agency (DeCA) sites has resulted in improved contractor maintenance, improved equipment operation, and decreased energy consumption. Additional refrigeration and HVAC maintenance contracts have increased operating efficiency.

The National Security Agency/Central Security Service (NSA/CSS) reduced energy costs by adjusting operating schedules, temperature settings, and varying equipment operations to meet HVAC demands. NSA/CSS has also published guidance to ensure motors and lighting fixtures are replaced and/or maintained in an energy "smart" fashion.

The National Imaging and Mapping Agency (NIMA) recently completed business process reengineering of the installation's maintenance processes including operations of HVAC and utility systems. In addition, projects are being initiated to upgrade the EMCS at the 
Bethesda, Maryland and St. Louis, Missouri installations to improve HVAC operations.

The Navy's 10-year plan for auditing all facilities, begun in 1995, is on schedule. In FY 1997, the Navy audited 27 million square feet for a total of 143 million square feet. This is approximately 37 percent of total Navy shore square footage.

In FY 1997, the Marine Corps funded more than $\$ 2$ million for energy surveys, training, and energy project development. These surveys and studies addressed:

- high voltage electrical distribution systems,

- water system analysis,

- renewable energy sources,

- lighting retrofits,

- steam trap maintenance and replacement,

- steam and condensate line replacement and insulation,

- gas line leaks,

- facility envelope insulation,

- window replacement,

- infrared analysis, and

- high-efficiency motor applications.

Comprehensive energy audits were completed for over 7 million square feet and identified over $\$ 36$ million of projects. The DOD Energy Conservation Investment Program (ECIP) funded five projects for $\$ 2.6$ million.

Each Air Force Major Command (MAJCOM) developed its own plan to accomplish energy surveys. Several MAJCOMS have survey teams at their headquarters.

DeCA completed audits at approximately 24 percent of its total facility inventory of 14.6 million square feet. Audits and surveys are determined by energy use, facility age and size, and current new construction or alteration status.

NSA/CSS has completed comprehensive audits on 96 percent of its owned space. Most long-term leased space is scheduled to be audited by FY 2000 .

Washington Headquarters Services (WHS) initiated two projects as a result of energy audits in FY 1997 to install direct digital controls in portions of the Pentagon and a nearby facility. This project will be expanded in FY 1998, in addition to a water conservation project at the Pentagon River Entrance.

\section{Renewable Energy Use}

In areas where it is cost competitive, DOD emphasizes the use of renewable energy resources. Service pro- grams are dependent on resources, geographic location, and economics. The Army continues to fund and implement renewable energy projects at installations where such projects prove to be cost effective:

- Yuma Proving Ground, Arizona. A $\$ 5$ million photovoltaic power station (900 kilovolt ampere utility-size array) was opened in March 1997 to offset peak demand and serve as an emergency power system for Yuma's water treatment plant.

- The Army Corps of Engineers, Pacific Ocean Division, awarded in early April 1997 a designbuild contract for $\$ 2.1$ million to install multiple photovoltaic power systems at Pohakuloa Training Area in Hawaii. The project consists of 14 kilowatts of arrays at remote locations to power a control tower for a small arms firing range and moving targets for a helicopter training range. A 10 kilowatt array to power runway lighting at a remote landing strip was also installed.

Current Navy renewable energy production is equivalent to 16 percent of its total usage ashore. Renewable energy will be emphasized for facility applications where it displaces the direct use of petroleum fuels. The Navy has a self-imposed goal of attaining an additional 10 percent of its energy from renewable, alternative, or geothermal sources as they become available. These activities resulted in an additional megawatt of photovoltaic generation installed in FY 1997. Additional accomplishments include:

- Geothermal. A 180-megawatt power plant is located at the Naval Air Weapons Station (NAWS) in China Lake, California. Revenue from the excess electric power from this geothermal plant is used to finance energy cost reduction efforts throughout the Navy.

- Solar. Seven hybrid photovoltaic/diesel power systems, totaling 1 megawatt of capacity, were installed in FY 1997, and several smaller systems were installed in previous years, resulting in savings of $\$ 1$ million per year. The largest is a 350 kilowatt system at the Superior Valley Test Site on the NAWS. Operational testing of solar domestic hot water systems continues in Navy housing in Pearl Harbor. As a result of this demonstration, the activity wants to increase installations up to 1,000 units.

- Wind. DOE and the Navy collaborated to award a contract to place two wind turbine generators on the Navy's facility at San Clemente Island. These will save approximately $\$ 500,000$ per year. 
The Marine Corps implemented two renewable energy projects. The first is a solar water heating retrofit project at Camp Pendleton, California, which will retrofit seven swimming pool heating systems and a barracks water heating system. The second is a photovoltaic power generating system to power a tank target range at Twentynine Palms, California.

Headquarters, Pacific Air Forces, Hickam AFB, Hawaii, installed an 18-kilowatt photovoltaic demonstration project at the vehicle repair shop. The Air National Guard headquarters implemented two projects that included active solar/renewable energy components in 1997. A solar water heating panel was installed on a Wing administration building at Madison, Wisconsin and a geothermal heat pump was included as part of a military construction project. Space Command's Advanced Airlift Tactics Training Facility in St. Joseph, Missouri, completed two renewable energy projects, a $\$ 3.5$ million wind farm and a $\$ 1.4$ million photovoltaic system at Ascension Island. These renewable projects will save 450,000 gallons of fuel oil per year and $\$ 9.5$ million over the 25-year life of the project.

\section{Training}

DOD components use training resources available in the DOD, DOE, other Government agencies, and the private sector.

The U.S. Army Corps of Engineers offered a course throughout FY 1997 to train energy managers. The Army Logistics Integration Agency presented a 34-hour training course for Army energy coordinators in Europe during FY 1997. During FY 1997, 1,404 Army personnel were trained.

Nearly 400 Navy personnel received technical training during FY 1997 through universities, associations, and Government agencies. The Navy also conducted four sessions of an in-house facilities energy management course covering Navy policy and instructions, energy data reporting, lighting technology, energy awareness, and project development.

During FY 1997, the Marine Corps sent its energy managers to the DOD Energy Managers Training Workshop in conjunction with the Association of Energy Engineers annual seminar and exposition.

The Air Force Institute of Technology (AFIT) Civil Engineering School at Wright-Patterson AFB in Ohio added a 40-hour energy management training course to its offerings. AFIT has also incorporated emphasis on energy efficiency in its other technical courses.
DeCA presents an annual energy/environment awareness briefing to approximately 160 commissary officers and managers as part of their Commissary Officer Basic and Advanced Courses. Store-orientated energy management training was completed in FY 1997 for 118 facility energy supervisors. DeCA also produced and distributed a training video entitled "Energy Reduction Action Plan for Facility Supervisors" to over 300 facilities.

\section{Energy Savings Performance Contracts}

The U.S. Army Corps of Engineers, Engineering and Support Center, Huntsville, Alabama, is the Technical Center of Expertise for energy savings performance contracts programming and project development within the Army. In FY 1997, a total of 18 indefinite delivery/ indefinite quantity (IDIQ) ESPCs were awarded for two separate regions. Seven contracts were awarded in January 1997 for the four-state region of Virginia, North Carolina, South Carolina, and Georgia. Eleven additional contracts were awarded in August 1997 to cover the rest of the U.S. and Puerto Rico. These 18 ESPC agreements, with up to 25-year terms, have a potential cumulative capital investment of $\$ 2$ billion. In FY 1997, two proposals were being evaluated for Fort Bragg, North Carolina, and Fort Stewart, Georgia and ESPC task orders were initiated for 13 additional sites.

The Naval Facilities Engineering Service Center (NFESC), Port Hueneme, California, teams with the Naval Facilities Contracts Office and Engineering Field Divisions to provide technical and contractual expertise to all Navy and Marine Corps activities and engineering field divisions. In FY 1997, the team awarded an ESPC for the Naval Surface Warfare Center, Crane, Indiana, for energy management control systems, direct digital controls, and boiler system replacement/improvements. The Navy assisted facility managers in deciding on ESPC viability at seven facilities. Six of these began implementing ESPCs. Execution will begin once endorsement from headquarters offices has been obtained. A regional ESPC, involving three facilities in the Caribbean area, will be awarded in June 1998.

The Navy plans to make maximum use of wide-area ESPC delivery order contracts through the DOE. Naval Facilities Engineering Command has signed a Memorandum of Understanding with DOE, establishing roles and respansibilities of a partnership that will facilitate use of DOE Super ESPCs. It has also signed a similar agreement with the U.S. Army Corps of Engineers, Engineering and Support Center, Huntsville to use their IDIQ ESPCs. At the end of FY 1997, the Marine Corps issued delivery orders on an Army Corps of Engineers ESPC, for Marine Corps Base, Hawaii. 
The Air Force ESPC program is two-tiered operating at the headquarters and installation level. The Air Force Civil Engineer Support Agency (HQ AFCESA) is the Air Force ESPC expert. The Air Force has successfully awarded four ESPC actions that are available to Air Force activities at seven locations. Additional ESPC contracts are being pursued to make ESPC resources available to all Air Force activities within the U.S.

DeCA will use the Huntsville ESPC contracts. DeCA currently has two shared energy savings contracts for 10 locations in the San Diego area. The contract was transferred to DeCA from the Navy for administration in March 1992.

The Defense Logistics Agency (DLA) had one ESPC in place in FY 1997 at the Defense Supply Center Richmond (DSCR), which was established through the Corps of Engineers.

\section{Utility Partnerships}

An example of a successful Army uitlity partnership is the agreement between Fort Lewis, Washington, and Tacoma Public Utilities, where equipment has been installed under a customized DSM program. DSM opportunities are under investigation at Fort Irwin, California; and Fort Bliss and Fort Hood, Texas. Fort Gordon, Georgia is investigating the feasibility of constructing peaking plants for management of electricity demand.

The Navy had implemented 66 DSM projects by the end of FY 1997. The Navy invested \$4.9 million and received $\$ 19$ million in utility financing and an additional $\$ 9$ million in financial utility incentives. The projects are located primarily in the Norfolk, Virginia and San Diego, California areas and cover a wide range of technologies, including lighting, natural gas vehicles, controls, and boiler systems. The Navy's Basic Ordering Agreement with San Diego Gas and Electric (SDG\&E) has been in place for several years. This $\$ 17$ million program, with SDG\&E contributing about 30 percent of installation costs, will save the Navy approximately $\$ 2.5$ million per year.

Engineering Field Activity Midwest entered into a major DSM agreement with Commonwealth Edison of Chicago to identify and implement projects at the Naval Training Center Great Lakes. The Navy has also entered into agreements with ENVEST, Pacific Gas and Electric, Sierra Electric, Puget Power, Public Services of New Mexico, Jacksonville Electric, Virginia Power, Peoples Gas, East Mississippi Electric Power Association, South Carolina Electric and Gas, Mississippi Power, and Central Texas Power and Light.
In FY 1997, Marine Corps Base Camp Pendleton continued implementation of the DSM contract with SDG\&E. Since the contract started, over 200,000 lighting fixtures have been retrofitted and over 600 leaks in the natural gas supply lines were repaired. Lighting upgrades totaling \$5.3 million were completed before the end of 1997 with Southern California Edison Electric Company and Marine Corps Logistics Base, Barstow, California and the Marine Corps Base at Twentynine Palms, California.

The Air Force has DSM projects at several installations. Little Rock AFB has a $\$ 15$ million project funded by Entergy through a DSM agreement for the installation of 1,535 ground source heat pumps. During FY 1997 the Air Mobility Command began using utility-sponsored DSM programs at Scott AFB, Illinois; Fairchild AFB, Washington; and Grand Forks AFB, North Dakota. A DSM with the Education and Training Command and NorAm Energy Corporation completed a lighting retrofit at 13 base facilities. Maxwel//Gunter AFB, Alabama, conducted energy surveys through a DSM agreement.

Southern California Edison assisted DeCA in evaluating the specialized aspects of commissary energy usage, providing intensive instrumentation and computer modeling of the Twentynine Palms Commissary.

\section{Environmental Activities}

DOD completed an Energy Star Buildings Memorandum of Understanding with DOE and EPA in April 1997. The Norfolk District, Army Corps of Engineers, in a joint demonstration with DOD and the EPA, developed a military housing design to achieve an "EPA 5 Star Energy Efficiency Rating" for 135 family housing units at Fort Lee, Virginia.

The Army, Marine Corps, DeCA, NSA/CSS, and WHS all continue to replace their older chiller and refrigeration systems with new energy-efficient units that eliminate dependence on CFC-based refrigerants.

\section{Energy Management Contact}

Captain Kevin Gross

Director, Energy and Engineering

Office of the Deputy Under Secretary of Defense

(Industrial Affairs and Installations)

U.S. Department of Defense, Room 206

400 Army Navy Drive

Arlington, VA 22204-2884

Phone: 703-604-6022

Fax: 703-604-6024 


\section{DEPARTMENT OF ENERGY (DOE)}

Energy Efficiency Performance and

Implementation Strategies

During FY 1997, the Department of Energy reported a 37.5 percent reduction in buildings consumption in Btu per gross square foot compared to FY 1985 . Contributing to this reduction is reduced missions activity and stand-down status at several of the DOE sites. Efforts are ongoing to consolidate operations and minimize energy use in vacated buildings.

\section{DOE Performance Toward Buildings Energy Reduction Goals}

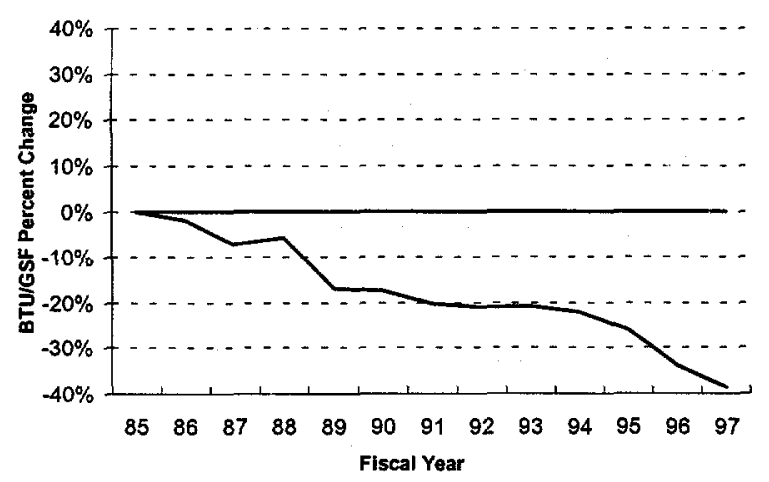

DOE Buildings Energy Use and Costs, FY97

$\begin{array}{lrr} & \text { BBtu } & \text { \$(Thou.) } \\ \text { Electricity } & 11,088.4 & 141,507.8 \\ \text { Fuel Oil } & 1,337.3 & 6,354.3 \\ \text { Natural Gas } & 6,595.2 & 22,074.2 \\ \text { Propane } & 61.7 & 487.6 \\ \text { Coal } & 3,514.8 & 5,964.5 \\ \text { Purchased Steam } & 1,783.7 & 11,946.7 \\ \text { Other } & 23.3 & 560.9 \\ & & \\ \text { Total } & 24,404.4 & 188,895.9\end{array}$

In FY 1997, DOE's Energy Management Team and Energy Management Steering Committee (EMSC) continued to integrate energy management activities into DOE program operations. The EMSC (comprising the Federal Energy Management Program and DOE Secretarial Officer representatives) establishes and implements internal policy for energy management and integrates that policy into DOE program operations.

Development continued and implementation began with performance agreements at DOE's operations offices and sites. Performance agreements with some field elements were negotiated with headquarters program offices to more clearly define energy management performance measures for achieving cost savings. Performance agreements have been developed with the eight DOE operations offices, which account for almost 80 percent of DOE's annual energy costs.

DOE employs operations and maintenance procedures to increase energy efficiency. Specific strategies include:

- Use of pre-engineered operating schedules to optimize chiller plant operations.

- Window replacement and space renovation,

- Thermograph techniques to locate "hot spots" in energy systems,

- Recalibration of thermostats and humidistats, cleaning of coils and louvers, and drip pan replacements,

- Set back and shut down of laboratory fumehood exhaust systems,

- Direct digital control systems to monitor and control HVAC equipment,

- Steam trap inspection and replacement programs,

- Annual boiler tune-up procedures,

- Inspection procedures for ensuring proper operation of controls on energy using equipment, and

- Review of building maintenance plans for energy use features.

In FY 1997, a number of site-wide comprehensive audits were completed at a number of DOE sites. Implementation of performance agreements will continue until all required DOE facilities have met minimum objectives. Examples of operational and energy efficiency projects accomplished in FY 1997 include the following:

- The Oak Ridge Y-12 Plant in Tennessee completed eight major projects. These retrofit projects have a total estimated annual energy savings of $\$ 1.8$ million. The largest savings is from the extended utility monitoring system project at two buildings, funded at $\$ 686,000$ with a projected annual cost savings of $\$ 431,000$. 
- The Lawrence Livermore National Laboratory completed prioritization surveys and comprehensive energy audits on 80 percent of its facilities. Energy efficiency projects were identified which would save an estimated \$1.4 million annually. Four retrofit projects were also completed which will result in an estimated $\$ 435,000$ in annual cost savings.

- The Lawrence Berkeley National Laboratory completed one electrical and six energy efficiency retrofits with an estimated $\$ 350,000$ in annual savings. The projects included an HVAC upgrade, including an energy monitoring and control system for the building and velocity controls for the fume hoods; replacement of the HVAC electric resistance space heating with natural gas fired hot water heating; replacement of the domestic hot water storage system with an 'instant on' electric system; process cooling water system upgrade; installation of building automation systems; and installation of energy-efficient motors.

- The Microelectronics Development Laboratory, at Sandia National Laboratories, completed modifications in FY 1997 to the process water treatment systems at a cost of $\$ 107,113$. Savings are estimated to be 38 million gallons of water a year with combined water, sewer, and energy savings totaling to $\$ 120,000$.

- The Savannah River Operations Office Spent Fuel Storage Division replaced a 3,600-horsepower water pump with a 600 -horsepower pump at a cost of $\$ 550,000$ with projected annual savings in excess of $\$ 1.3$ million.

- Argonne National Laboratory-East developed a free cooling concept which was implemented through low-cost cooling modifications. The result is energy cost savings of about $\$ 55,000$ per year.

\section{Energy Showcase Facilities}

During FY 1997, construction and occupancy was completed on two very large Federal showcase facilities at the Richland Operations Office. The Environmental Molecular Science Laboratory and the Hazardous Materials Management and Emergency Response Training and Education Center were designed and built with energy-efficient technologies such as:

- variable air volume;

- heat recovery;

- premium efficiency motors in ventilation fans

- energy-conserving lighting and windows; and

- occupancy sensors.
In October 1997, DOE held its 18th Annual Awards ceremony at DOE headquarters in Washington, DC. The DOE Headquarters Energy Efficiency Awards Program recognizes DOE individuals and organizations who have made significant contributions to energy efficiency as a result of leadership and management excellence. The winners are presented with a plaque and a letter of congratulations from the Secretary of Energy. A number of DOE sites have their own internal energy efficiency awards programs; for example, the Argonne National Laboratory-East Pacesetter Award Program.

Partnership Initiatives/Team Franchising Activities The Federal Energy Management Program (FEMP), the Federal Aviation Administration, the California Institute for Energy Efficiency, and a variety of Center for Building Sciences Research Programs provided approximately $\$ 400,000$ to Lawrence Berkeley National Laboratory for team franchising efforts related to building measurement and verification protocols.

The Laboratory also completed the energy efficiency report for the Seattle Air Route Traffic Control Centers (ARTCCs) and reviewed energy audits of the Denver and Salt Lake City ARTCCs.

Lawrence Livermore National Laboratory provided franchising services to the Los Alamos National Laboratory, DOE Headquarters Energy Management Team, and also provided consulting services to Greening America in its report to FEMP.

The Oak Ridge $Y$-12 Plant engineering staff provided energy audit assistance and training on Market Manager software and consultation services for the DOE Princeton Plasma Physics Laboratory. They also worked with the Oak Ridge Centers for Manufacturing Technology and the Oak Ridge National Laboratory Energy Division to provide energy management services to other Federal agencies, private sector companies, and state and local governments.

\section{Funding}

No project funding for DOE in-house energy management was appropriated for FY 1997. However, DOE continued to implement new projects through alternative financing mechanisms when and where possible.

\section{Energy Savings Performance Contracts}

DOE has four energy savings performance contracts in place, two of which were awarded in FY 1997:

- Richland Operations Office's Hanford Site awarded an ESPC valued at $\$ 160.3$ million over 25 
years. This is one of the largest Federal contracts of its type. Part I provides energy conservation measures related to steam systems for Areas 200 and 300. Part II implements cost-effective, reliable energy conservation measures for all facilities in those areas. The contract is expected to save DOE about $\$ 108$ million over 25 years.

- Lawrence Livermore National Laboratory signed a Master Task Agreement with two energy service contractors to perform ESPC tasks at the Laboratory. Final task assignments were in the process of being made at the end of FY 1997.

- The ESPC at the headquarters Forrestal Building in Washington, DC, signed in FY 1993 is saving approximately $\$ 400,000$ and over 6 million kilowatt hours per year.

- The ESPC at the Lawrence Berkeley National Laboratory, California, is producing cost savings estimated at $\$ 44,500$ in the first year and increasing to $\$ 88,100$ at the end of FY 1997.

\section{Utility Partnerships}

Examples of DOE sites participating in or providing utility incentive programs include the following:

- Bonneville Power Administration is a DOE Federal electric power marketing organization in the Northwest which provides power to various public utilities. BPA offers several energy conservation incentive programs to its utility customers, such as the Manufactured Housing Acquisition Program (MAP), which offers $\$ 2,500$ per house to home manufacturers if the home is built to technical specifications that reduce up to half the electricity needed to heat the home.

- Argonne National Laboratory-East, Illinois, continued to participate in a demand side reduction program with their local utility. Savings are estimated to be approximately $\$ 80,000$ for the year.

- Lawrence Berkeley National Laboratory implemented a holiday shutdown by turning off equipment and resetting space temperature setpoints. Savings amounted to more than 1.0 million kilowatt hours and 1,011 therms valued at $\$ 54,538$.

- Albuquerque Operations Office signed a $\$ 1.6$ million utility incentive contract in FY 1997 with the Public Service Company of New Mexico to install gas-fired heating systems in 11 buildings. The steam-to-hot-water conversion project will reduce energy consumption and eliminate all steam costs. The project is expected to generate savings of $\$ 250,000$ per year.

\section{Vehicles}

DOE has an ongoing project to improve vehicle efficiency, including acquiring alternative fuel vehicles (AFVs), downsizing vehicles, upgrading preventive maintenance programs, improving maintenance techniques, expanding waste minimization programs to reduce vehicle waste streams, implementing driver awareness training, and providing employee outreach.

In FY 1997, DOE acquired over $100 \mathrm{AFVs}$ with most being compressed natural gas bi-fuel and dedicated vehicles. A few flex-fueled ethanol and methanol vehicles were also acquired as were some compact electric pick-up trucks. Additional AFV acquisitions are planned for FY 1998.

Most DOE sites have an ongoing employee commuter program to encourage gasoline conservation by employees. These promote ridesharing and mass transit.

Argonne National Laboratory-East reduced the number of cars and light trucks in its fleet by over 42.3 percent (from 234 to 135) and the total number of vehicles by over 27.5 percent (from 396 to 287 ).

\section{Environmental Activities}

Pacific Northwest National Laboratory and the City of Richland formed a partnership called "Rebuild America," that will expand to include schools, hospitals, and private companies. It is designed to expedite improvements in the City's energy metering/billing system and in the energy efficiency of the City's own facilities.

During FY 1997, DOE continued to focus on reduction of CFCs through projects to replace CFC chillers. Other projects include fluorescent lamp recycling, procuring recycled goods and products, reduction of power plant emissions in California, and site-wide recycling of aluminum cans, batteries, cardboard, paper, and lamps.

\section{Energy Management Contact}

Mr. Victor Petrolati, EE-91

DOE Energy Management Team Leader

Federal Energy Management Program

Office of Energy Efficiency and Renewable Energy

U.S. Department of Energy

1000 Independence Avenue, SW

Washington, DC 20585-0121

Phone: 202-586-4549

Fax: 202-586-3000 


\section{DEPARTMENT OF HEALTH AND HUMAN SERVICES (HHS)}

\section{Energy Efficiency Performance and \\ Implementation Strategies}

The Department of Health and Human Services reported a 0.8 percent reduction in buildings consumption in Btu per gross square foot in FY 1997 when compared to FY 1985.

HHS Performance Toward Buildings Energy Reduction Goals

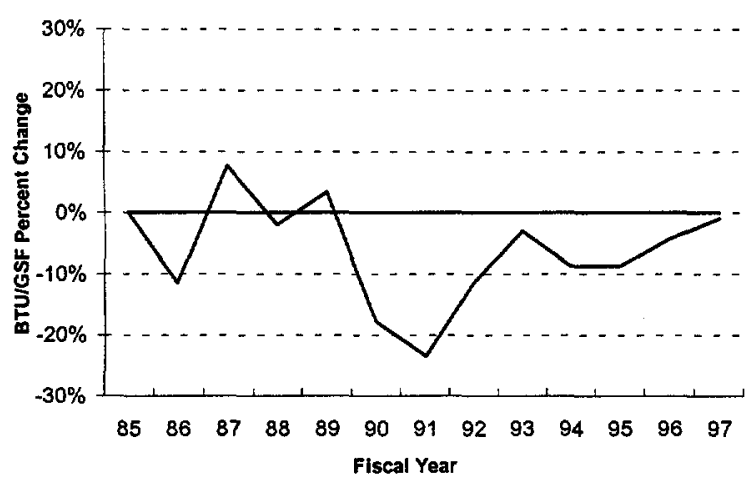

HHS Buildings Energy Use and Costs, FY97

$\begin{array}{lrr} & \text { BBtu } & \text { \$(Thou.) } \\ \text { Electricity } & 2,872.6 & 50,510.0 \\ \text { Fuel Oil } & 639.5 & 3,529.0 \\ \text { Natural Gas } & 3,761.5 & 14,569.0 \\ \text { Propane } & 121.2 & 853.0 \\ \text { Purchased Steam } & 23.0 & 342.0 \\ & & \\ \text { Total } & 7,417.8 & 69,803.0\end{array}$

HHS has developed 10-year plans for each of its operating divisions (OPDIVs). The OPDIVs were then responsible for the completion of prioritization surveys and comprehensive energy audits within each of their facilities. Each OPDIV 10-Year Audit Plan was developed based on prioritization survey results. Audits were completed at 11.5 percent of HHS square footage in FY 1997 , resulting in a cumulative 29 percent of total HHS space having been audited. These audits have been performed by utility companies, energy contractors, inhouse personnel, university engineering students, university industrial assessment centers, and the DOE SAVEnergy audit program.

Energy and water conservation projects and initiatives performed during FY 1997 include:
- Indian Health Service (IHS). Eight new comprehensive energy audits were performed. Recommendations from these audits will be used to prepare an energy savings performance contract package. Energy savings measures identified included lighting retrofits, installing energy management control systems, replacing chillers, air-balancing HVAC systems, replacing heat exchangers, and installing energy-efficient motors. IHS will begin to implement many of these actions in FY 1998. In FY 1997 completed projects included: the installation of a ground source thermal water closed loop system, lighting retrofits, boiler and chiller upgrades, installation of HVAC control systems, insulation upgrades, and building envelope upgrades.

- Food and Drug Administration (FDA). At the start of FY 1997, the HHS Energy Officer met with FDA officials to discuss HHS's centralized energy conservation plans. As a result, the FDA is developing a comprehensive formal energy management plan that is supported by upper level management. A lighting retrofit project at the Laurel, Maryland, facility has been planned, which is expected to save 957 million Btu and $\$ 14,000$ annually. A roof replacement project was performed at the Winchester Engineering and Analytical Center in FY 1997 , which will reduce heat loss by approximately 60 percent.

- Center for Disease Control (CDC). In FY 1997, CDC spent approximately $\$ 1.3$ million on HVAC upgrades that originated from an in-house analysis. Anticipated annual savings are 2.7 billion Btu and $\$ 47,000$. One project included a recirculating cooling tower to provide chilled water to HVAC cooling equipment.

- Gillis W. Long Hansen's Disease Center, Health Resources and Services Administration (HRSA), Carville, Louisiana. In FY 1997, a direct digital controls (DDC) project for the HVAC systems in 10 buildings was awarded, as well as a new DDC controlled walkway lighting system. Annual savings are expected to be 2.3 billion Btu and $\$ 45,600$.

- Office of the Secretary (OS) Headquarters, Hubert H. Humphrey Building, Washington, DC. Lighting retrofits performed as the result of an in-house analysis will save $\$ 10,600$ annually. GSA funded and completed an extensive chiller plant upgrade. 
Plans for FY 1998 include the installation of solar film on the windows, analyzing other solar applications, and reprogramming the energy management control system to automatically curtail the HVAC operations during unoccupied hours.

- Program Support Center (PSC), Parklawn Building, Rockville, Maryland. Some delamping was performed, and occupancy sensors were installed. Also, the owner of this leased building funded a chiller replacement project initiated by the PSC building management staff.

- National Institutes of Health (NIH). The Main Campus, Bethesda, Maryland, is implementing a major upgrade to its central heating and cooling plant. The project includes the following measures and savings: installation of high-efficiency chillers $(\$ 820,000)$; implementation of variable-speed secondary pumping $(\$ 720,000)$; increase of chilled water temperature differential $(\$ 10,000)$; addition of steam-driven turbines on new electric chillers $(\$ 110,000)$; incorporation of free cooling in power plant design $(\$ 340,000)$; use of boiler economizers $(\$ 250,000)$; and modification of chiller operation during off-peak months $(\$ 35,000)$.

In FY 1997, NIH continued the development of its nascent centralized energy management program. An $\mathrm{NIH}$ civil/environmental engineer will assist the $\mathrm{NIH}$ energy engineer with the management and implementation of the energy program.

FY 1997 was the first year of the HHS Energy and Water Management Awards. Seven awards were presented to individuals, small groups, and organizations for their achievements in energy management and conservation.

\section{Energy Showcase Facilities}

HHS has two designated energy showcases, the Hubert H. Humphrey Building and the NIH Frederick Cancer Research and Development Center (FCRDC), Frederick, Maryland. This is a 90-building facility, occupying approximately 1 million square feet, located on the DOD Fort Detrick campus. This was the first HHS component to enter into a Basic Ordering Agreement, which was signed by HHS, DOD, the operating and technical contractor at Fort Detrick, and the local utility.

\section{Training}

OS held a one-day energy seminar in FY 1997. HHS energy managers from across the country attended to learn the latest from speakers from DOE, the National
Renewable Energy Laboratory, Pacific Northwest National Laboratory, HHS, and private industry. Topics discussed included energy auditing, renewable energy, water conservation, ESPCs, energy awareness, energyefficient operations and maintenance, and new technologies.

CDC sent seven individuals to energy management training courses in FY 1997. One HRSA energy manager attended a course sponsored by the local utility.

The IHS energy coordinator continues to offer a oneweek course for the IHS Area engineers and facility managers. At the completion of the course, the attendees have the option of taking a four-hour exam administered by the Association of Energy Engineers for energy manager certification.

The Navajo Area Headquarters offered a shorter version of the course that provided a very practical overview of energy management. This training was attended by the Navajo Service Unit Facility managers and Area staff engineers.

The IHS Albuquerque Area conducted a course for its engineers and facility managers. Approximately ten people completed this training. In the Billings Area, facility managers are annually trained on the direct digital controls of their specific HVAC system.

\section{Funding}

The total amount invested in energy and water efficiency projects in FY 1997 was $\$ 2.9$ million, which was a 7.6 percent increase from FY 1996. In prior years, direct agency funding was the primary vehicle for implementing energy and water efficiency projects. In FY 1998, this funding is expected to decrease to $\$ 2.1$ million. It is expected that ESPCs will be relied upon more in the future.

\section{Energy Savings Performance Contracts}

FY 1997 was the first year for HHS involvement in energy savings performance-type contracts. Three of the seven OPDIVs entered into these contracts.

- The NIH FCRDC became partners with DOD in developing and signing a Basic Ordering Agreement with Allegheny Power, the local utility.

- CDC facilities in Cincinnati, Ohio, are utilizing a GSA area wide public utilities contract developed with the local utility. In early FY 1998, CDC in Atlanta will participate in that regions GSA area wide contract. 
- The FDA National Center for Toxicology Research entered into a GSA area wide public utilities contract with Entergy (one of GSA's contractors).

The IHS Aberdeen (South Dakota) Area office is working with engineers from the IHS Engineering Services in Seattle to prepare a Super ESPC delivery order with DOE. The Area expects a delivery order to be awarded in the second or third quarter of FY 1998.

\section{Utility Partnerships}

HHS facilities are beginning to purchase natural gas on the spot market. In FY 1998, PSC will purchase deregulated gas from Washington Gas Energy Services, with expected savings of approximately $\$ 25,000$ for the year. The IHS Oklahoma Area is also considering this type of purchase.

\section{Environmental Activities}

In FY 1997, the HHS Energy Officer and the OPDIV energy coordinators met with EPA to discuss the Federal Energy Star Buildings Program. Each HHS OPDIV will sign a memorandum of understanding for the program. These will be forwarded from the HHS Energy Office to each OPDIV head with a brief description of the program and a letter stressing the benefits of energy conservation and of becoming part of the Energy Star program.

\section{Energy Management Contact}

Mr. Scott Waldman

Department-Wide Energy Manager

U.S. Department of Health and Human Services

HHS Cohen Building, Room 4700

330 Independence Avenue, SW

Washington, DC 20201

Phone: 202-619-0426

Fax: 202-619-1407 


\section{DEPARTMENT OF HOUSING AND URBAN DEVELOPMENT (HUD)}

\section{Energy Efficiency Performance and}

Implementation Strategies

During FY 1997, the Department of Housing and Urban Development reported a 6.5 percent decrease in buildings consumption in Btu per gross square foot compared to FY 1985.

\section{HUD Performance Toward Buildings Energy Reduction Goals}

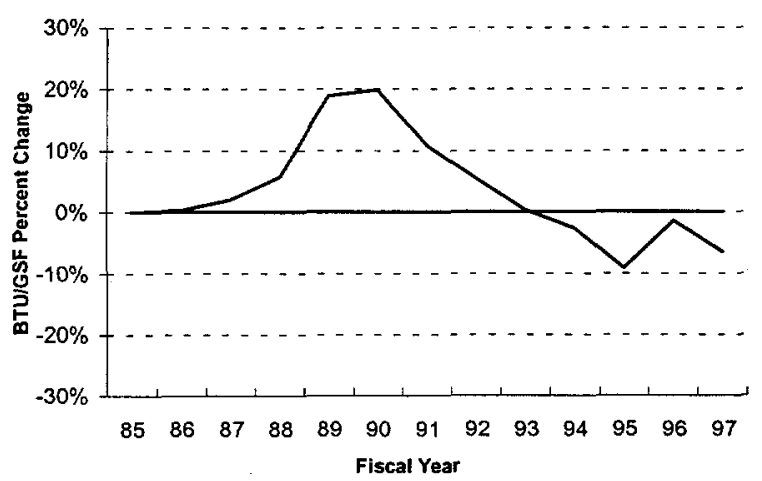

HUD Buildings Energy Use and Costs, FY97

$\begin{array}{lrr} & \text { BBtu } & \text { \$(Thou.) } \\ \text { Electricity } & 83.9 & \mathbf{1 , 8 2 4 . 0} \\ \text { Natural Gas } & 0.2 & 1.7 \\ \text { Purchased Steam } & 25.2 & 376.4 \\ & & \\ \text { Total } & 109.3 & 2,202.1\end{array}$

HUD's energy strategy includes continuously reviewing operations to identify opportunities for energy savings, aggressively pursuing identified energy conservation measures, and purchasing of energy-efficient equipment, such as Energy Star computers.

In FY 1997, HUD completed two major energy efficiency projects at its headquarters building in Washington, DC. These were:

- A chiller replacement project was completed in March 1997. Existing CFC chillers were replaced with non-CFC, energy efficient chillers; and

- An upgrade of the variable frequency drives on the building's eight main air handlers and return fans was completed in December 1997.
A number of initiatives are planned for FY 1998, including:

- Completion of automation control system for on/off control of the building's 1,584 fan coil units.

- Lighting retrofit throughout building. Replacing T12, 34-watt fluorescent lamps with magnetic ballasts with $\mathrm{T}-8,32$-watt lamps with reflectors and electronic ballasts.

\section{Energy Showcase Facilities}

The HUD headquarters building was designated a showcase in recognition of its chiller replacement program.

\section{Funding}

HUD submits energy conservation measures to GSA for funding through their fund for agencies that have been delegated control of their buildings. HUD's Office of Procurement and Contracts has escalated the procurement process to award energy conservation measures within the fiscal year they are proposed.

\section{Utility Partnerships}

During FY 1997, HUD continued participation in Potomac Electric Power Company's Electrical Load Curtailment Program. This will continue in FY 1998.

\section{Energy Management Contact}

Ms. Elaine Robinson

Director, Building Operations Division

Department of Housing and Urban Development

Room 5180

4517 th Street, SW

Washington, DC 20410-3000

Phone: 202-708-2711

Fax: 202-708-0299 


\section{DEPARTMENT OF THE INTERIOR (DOI)}

\section{Energy Efficiency Performance and}

Implementation Strategies

In FY 1997, the Interior Department reported a decrease in energy consumption in buildings of 16.0 percent in Btu per gross square foot compared to FY 1985.

\section{Interior Performance Toward Buildings Energy Reduction Goals}

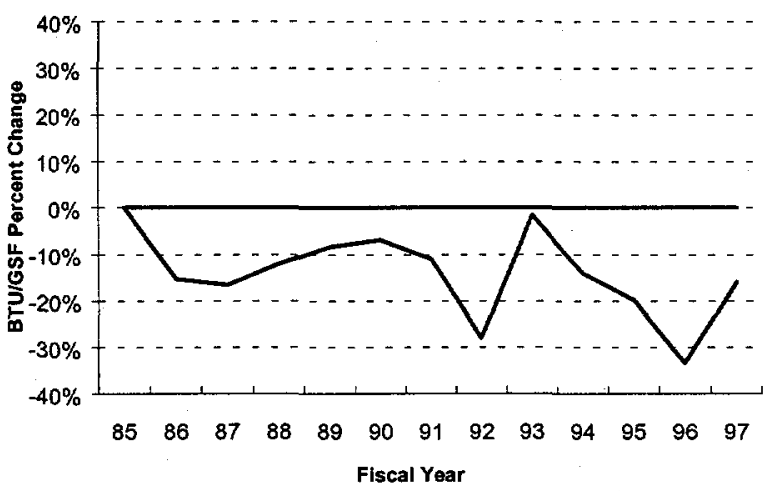

Interior Buildings Energy Use and Costs, FY97

$\begin{array}{lrr} & \text { BBtu } & \text { \$(Thou.) } \\ \text { Electricity } & 1,413.5 & 31,190.3 \\ \text { Fuel Oil } & 465.5 & 3,850.2 \\ \text { Natural Gas } & 1,329.7 & 5,870.8 \\ \text { Propane } & 334.2 & 3,423.2 \\ \text { Coal } & 1.5 & 0.8 \\ \text { Purchased Steam } & 43.0 & 324.5 \\ \text { Other } & 28.1 & 184.2 \\ & & \\ \text { Total } & 3,615.4 & 44,844.0\end{array}$

The Interior's Energy Management Plan for Buildings and Facilities, revised in June 1995 to meet requirements of EPACT and Executive Order 12902, provides guidance to its Bureaus in establishing and implementing energy management programs.

Energy conservation measures are being applied on a daily basis, including informing employees through various means of energy and water conservation needs, purchase of energy-efficient equipment, replacing lighting and plumbing fixtures with energy- and waterefficient equipment, and entering into demonstration projects and partnerships.

Operation and maintenance procedures have been adopted at many DOI bureaus which require that all new or replacement purchases of energy-consuming devices be evaluated on energy efficiency characteristics. Procedures also require that incandescent lamps be replaced with compact fluorescent lamps; fluorescent lamps be replaced with lower wattage and more efficient lamps; air conditioners and heat pumps, when worn out, be replaced with high energy rating units; and faucets and toilets be replaced with low water consumption units.

The following are energy conservation initiatives that were underway during FY 1997:

\section{Pacific Northwest Region:}

- Snake River Area West. Energy conservation measures included the replacement of old PCB ballast light fixtures, retrofit of fluorescent lights, installation of double glazing, installation of insulation in two basement offices, replacing old water heaters, and installation of a new insulated back door.

- Snake River Area East. The replacement of windows with new thermal pane windows.

\section{Mid Pacific Region:}

- Willows Construction Area Office. Energy conservation measures included ceiling insulation, wall insulation and weather stripping; energy efficient windows and sunscreens; occupancy sensors; and energy efficient air conditioning and heating units.

- New Melones Reservoir, California. Measures included installation of motion sensors; and high efficiency fluorescent lighting.

- Folsorn Dam, California. The installation of 27watt compact fluorescent bulbs.

- Lake Berryessa Recreation Facility, California. A lighting retrofit, and the continued installation of motion sensor lighting controls.

\section{Upper Colorado Region:}

- The Provo Area Office, the Weber Basin Job Corps Center, Utah, and the Collbran Job Corps Center, Colorado each entered into energy savings performance contracts.

The Bureau of Land Management (BLM) has been actively working on solar energy projects. During FY 1997 , ten solar projects were completed. These projects included water pumping applications, campground lighting, and facility power. 


\section{Showcase Facilities}

DOI designated the National Conservation Training Center (NCTC), West Virginia as a new construction energy showcase. Fish and Wildlife Service engineers used computer models to verify compliance with Federal regulations, extensively incorporated passive solar energy strategies and energy efficient technologies into the design, and specified use of recycled materials in construction.

The Bureau of Reclamation has two showcase facilities. Glen Canyon Dam Visitor's Center demonstrates energy conservation within a hydroelectric generating facility. Lighting retrofits and occupancy sensors are being installed throughout the facility. Toilets were replaced with low-flush units, single pane windows were replaced with insulated glass, and the existing solar hot water heating system was repaired.

The Denver Federal Center showcase facility is a joint effort between Reclamation, GSA, DOE, EPA, the local water utility, and four manufacturers of watersaving devices. This two-year project demonstrates and evaluates water conservation technologies and provides a learning center for other Federal agencies, private organizations, and the general public. The project will also document the performance of water conservation devices, determine life-cycle cost savings, and determine if improvements are needed before deployment in the Federal sector.

Reclamation's Pacific Northwest Region showcase facility is the new Centennial Job Corps Center in Nampa, Idaho. It was completed in September 1997. Included at the October dedication ceremony was an exhibit which featured the following energy-efficient and water conservation technologies:

- Water loop heat pumps and a direct digital control energy management system.

- Low-flush urinals and toilets, flow-restricted showers, and thermally-efficient hot water heaters.

- Occupancy sensors, T-8 fluorescent lamps, compact fluorescents, and self-luminous exit signs.

- Xeriscaping. Drought-tolerant grasses.

- Windows. Insulating glass, low-E double panes.

During FY 1997, DOI nominated five additional showcase buildings. They include Fish and Wildlife Service buildings in Indiahoma, Oklahoma, and Prairie City, Idaho; Reclamation buildings in Bullhead City,
Arizona, and Nampa, Idaho; and the U.S. Geological Survey's EROS Data Center's Mundt Building in Sioux Falls, South Dakota.

\section{Training}

Energy managers involved in building energy efficiency and water conservation have attended workshops offered by the DOE as well as training offered by GSA, EPA, the Association of Energy Engineers, public utilities, and at Bureau energy coordinators meetings.

DOI conducted a two-day seminar on energy management for representatives from the Bureau of Indian Affairs, Fish and Wildlife Service, and the Bureau of Reclamation in Albuquerque, New Mexico in June 1997.

\section{Funding}

DOI funded $\$ 300,000$ for retrofits and capital equipment in FY 1997 and estimate funding of $\$ 470,000$ for FY 1998. DOI funding for energy retrofits and capital improvements comes from the Bureaus' operations, maintenance, construction, and rehabilitation funds.

The Fish and Wildlife Service nominated several sites for energy audits utilizing the SAVEnergy Audit program conducted through DOE FEMP contractors. Audits have identified energy conservation opportunities and retrofits that estimated costs exceeded the available funding for FY 1997. Bureaus report having backlogs of energy conservation maintenance programs totaling millions of dollars.

Maintenance projects are reviewed for their relation to energy conservation measures, and a high priority is placed on those projects that would reduce energy consumption.

\section{Energy Savings Performance Contracts}

An ESPC for lighting is currently in place at the National Park Service's Statue of Liberty and Ellis Island National Monument. DOI continues to explore locations where energy savings performance contracts might be effectively implemented. Several offices have trained contract specialists and energy managers to negotiate performance contracts.

Reclamation produces much of the power it consumes, or pays very little. At larger facilities, Reclamation has not been able to enter into any ESPCs. However, in FY 1997, Reclamation entered into three ESPCs at the Weber Basin Job Corps Center, Collbran Job Corps Center, and the Provo Area Office. 
Based on a Fish and Wildlife Service technical review, a work group examining the feasibility of ESPCs determined that their facilities, due to their relative small size, low energy consumption and remote/isolated locations, do not have potential for such contracts.

The use of the indefinite delivery, indefinite quantity contracts, developed by the National Park Service in conjunction with the DOE, are expected to increase familiarization with ESPCs and help increase the number of ESPCs in the DOI. Bureaus are very optimistic about participating in the DOE's Super ESPCs.

\section{Utility Partnerships}

The U.S. Geological Survey consults with servicing utilities at least annually to ensure that each facility has the lowest possible rate schedule. Utilities are consulted about incentive and rebate opportunities. High energyuse systems are scheduled to take advantage of off-peak rates.

Fish and Wildlife Service field stations also maintain contact with their local utilities in order to obtain any available demand side management services.

\section{Vehicles}

In FY 1997, DOI had a fleet of approximately 32,000 vehicles, of which approximately 50 percent are owned by DOI, while the other 50 percent are leased through the GSA.

A cornerstone of DOI's efforts to reduce dependency on petroleum is the use of cleaner-burning fuels in its motor vehicles. Currently, DOI has over 300 alternative fueled vehicles (AFV) nationwide. About 80 percent use an alcohol-based fuel (methanol or ethanol/gasoline blend) and 15 percent use natural gas and propane gas. Less than 5 percent of the AFVs are powered by electricity or bio-diesel derived from industrial rapeseed, canola, or soybeans.

Working closely with other Federal agencies and industry, DOI seeks to:

- Establish clean transportation zones for demonstrating alternative fuel technologies;

- Support the DOE's Clean Cities initiatives;

- Convert the fleet, as much as possible, to AFVs using DOE's AFV program funds and GSA's vehicle leasing program;

- Through the assistance of the DOE and DOT, develop transportation systems at National Parks incorporating more energy-efficient and environmentally-friendly transportation modes such as alternative fueled transit vehicles, cleanburning fixed rail systems, alternative fueled water shuttles and bicycles, and by establishing transportation hubs, intelligent transportation systems, information kiosks, and bicycle and walking trails;

- Participate in DOE heavy truck demonstration projects to test operation and performance of heavy duty AFVs;

- Demonstrate electric, natural gas, etc. through vehicle loaners with utilities; and

- Promote via visitor education programs the use of AFVs as an important component in creating sustainable communities.

The following are examples of recent accomplishments in DOI cost-sharing partnerships:

- Acquisition of electric mass transit vehicles at the Patuxent National Wildlife Visitor Center, Back Bay National Wildlife Refuge, Golden Gate National Recreational Area, Yosemite National Park and Grand Canyon National Park;

- Participation in a DOE heavy truck demonstration project in the Washington, DC area, resulting in DOI acquisition of a natural gas powered refuse hauler;

- DOI acquired DOE and GSA funding to purchase AFVs and a fueling infrastructure;

- Establishment of various projects to demonstrate the applications of electric, natural gas, and biodiesel-powered vehicles;

- Development of a framework to turn other DOI facilities into multi-modal clean transportation zones; and

- Establishment of convenient fueling stations at several urban and rural DOI sites.

\section{Energy Management Contact}

Mr. John Moresko

Property Management Specialist

Office of Acquisition and Property Management

U.S. Department of the Interior

Main Interior Building, Room 5512

1849 C Street, NW

Washington, DC 20240

Phone: 202-208-5704

Fax: 202-208-6301 


\section{DEPARTMENT OF JUSTICE (DOJ)}

\section{Energy Efficiency Performance and Implementation Strategies}

In FY 1997, the Department of Justice reported a decrease of energy consumption in buildings of 36.8 percent in Btu per gross square foot compared to FY 1985.

\section{Justice Performance Toward Buildings Energy Reduction Goals}

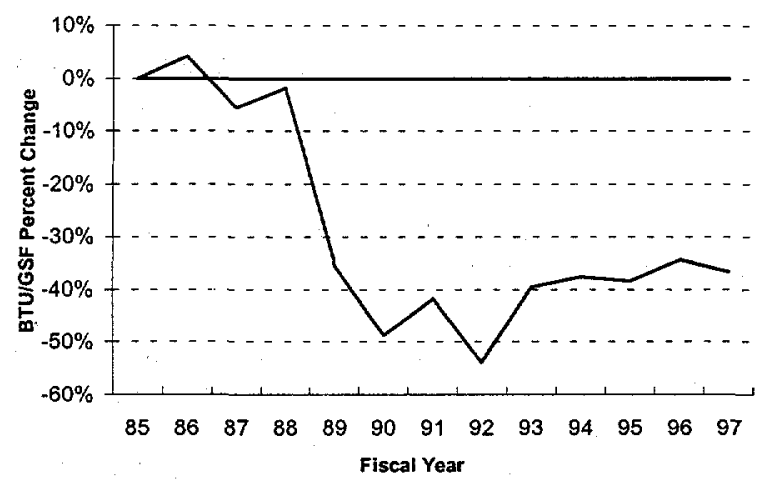

Justice Buildings Energy Use and Costs, FY97

$\begin{array}{lrr} & \text { BBtu } & \text { \$(Thou.) } \\ \text { Electricity } & 2,729.2 & 46,643.1 \\ \text { Fuel Oil } & 124.4 & 620.5 \\ \text { Natural Gas } & 4,723.8 & 23,407.0 \\ \text { Propane } & 10.5 & 76.1 \\ \text { Coal } & 69.1 & 131.0 \\ \text { Purchased Steam } & 329.6 & 3,167.4 \\ \text { Other } & 17.0 & 163.4 \\ & & \\ \text { Total } & 8,003.7 & 74,208.5\end{array}$

DOJ has reviewed and updated its energy management conservation efforts and plans in accordance with Executive Order 12902, and has provided guidance and information to all bureaus concerning energy conservation plans.

Energy conservation highlights from FY 1997 include:

\section{DOJ Headquarters:}

- Main Justice Building (MJB), Washington, DC. Projects such as the installation of occupancy sensors and more energy efficient lighting fixtures occurred in FY 1997. Major renovation is scheduled to begin in FY 1998 under the direction of GSA. Numerous energy conservation enhancements will be incorporated in the seven-year renovation project including the installation of energy-efficient chillers, electric motors, pumps, HVAC equipment, and lights.

\section{Federal Bureau of Investigation:}

- J. Edgar Hoover building, Washington, DC. Occupancy sensors were installed to control lighting in offices, bathrooms, and hallways. Old ballasts were replaced with electronic switching. An energy management system is being designed, with $\$ 1.8$ million allocated from GSA. At least $\$ 690,000$ of additional energy conservation projects will be implemented in FY 1998, including replacing garage lights, installing high-efficiency motors, and installing variable speed drives for pumps.

- FBI Academy, Quantico, Virginia. Equipment is being converted from fuel oil to natural gas. Twenty-five-year-old chillers are being replaced with models that are 30 percent more efficient. All future facilities, such as the 180,000-square-foot training facility and the 500,000-square-foot laboratory, are designed using the most energyefficient methods appropriate for the facility.

\section{Bureau of Prisons (BOP)}

- Federal Correctional Institute (FCI) Otisville, New York. A lighting retrofit was performed, resulting in annual savings of 148,000 kilowatt hours and $\$ 26,000$.

- Metropolitan Detention Center, Los Angeles, California. A project was established to replace the existing boilers with more efficient models. Annual savings are estimated at approximately 10,000 therms of natural gas. Also, a new jockey pump was installed with annual savings in excess of 100,000 kilowatt hours and $\$ 8,000$.

- FCI Balstrop, Texas. The existing chiller was replaced, with expected annual savings of 1.5 million kilowatt hours and approximately $\$ 60,000$.

- FCI Estill, South Carolina. A lighting retrofit will save 140,000 kilowatt hours and $\$ 10,000$ annually.

- Federal Prison Camp (FPC) Seymour Johnson Air Force Base, North Carolina. A lighting retrofit and the replacement of exit signs with LED models will save 150,000 kilowatt hours and $\$ 9,000$ annually. Also, an energy management system was installed to reduce both electricity and natural gas 
consumption. Approximately 350,000 kilowatt hours, 15,000 therms, and $\$ 30,000$ will be saved annually.

- FCI Petersburg, Virginia. Energy efficient lighting fixtures and controls were installed and are expected to save 500,000 kilowatt hours and more than $\$ 30,000$ annually. Another project to allow more efficient boiler operation during non-heating months is expected to save 4 billion Btu and $\$ 20,000$ annually.

- FCI Marianna, Florida. An energy management system was installed to reduce consumption of electricity and natural gas. Annual savings are expected to be over 950,000 kilowatt hours, 31,000 therms, and in excess of $\$ 80,000$.

- FPC Yankton, South Dakota. Windows were replaced at selected locations throughout the institution. Projected annual savings are over 50,000 therms of natural gas and more than $\$ 22,000$.

- FCI Florence, Colorado. A lighting retrofit is expected to save more than 1.3 million kilowatt hours and $\$ 50,000$.

- FCI Phoenix, Arizona. A lighting retrofit will save more than 500,000 kilowatt hours and $\$ 38,000$.

BOP has completed 66 energy audits to date. The audits have enabled the BOP to justify budget enhancements and the establishment of energy conservation projects.

\section{Training}

Employees attend low- or no-cost classes such as DOEsponsored classes and meetings, and GSA classes whenever possible.

BOP conducts a facilities management training course that includes energy conservation topics. About 25 employees attended in FY 1997. Topics include energy program review, required documentation for requesting energy projects, and life-cycle costing. An overview of the energy conservation program was given in July 1997 at the National Facilities Managers Training. Facility Managers from every BOP institution, regional staff, and central office attended.

\section{Funding}

Federal funds for energy conservation projects are requested on a case-by-case basis. Projects are prioritized in order of emergency, life and fire safety, and mission operational or maintenance necessity. Consideration is given to life-cycle cost effectiveness and equipment condition. DOJ also continues to seek funding from other agencies (GSA, DOE) to accomplish energy savings projects and energy audits.

\section{Energy Savings Performance Contracts}

BOP entered into an energy savings performance contract for the FCI Phoenix, Arizona, in FY 1996. This contract was for the installation of a solar energy water recovery system that will provide for the potential use of a renewable domestic heated water system. It will begin to show measurable energy savings in FY 1998.

\section{Utility Partnerships}

Both electric and natural gas utilities have worked with BOP by providing services, guidance, and financial incentives involving lighting and HVAC systems. The cost savings generated by these efforts have allowed for the funding of additional projects.

\section{Vehicles}

DOJ is looking at the potential for use of alternative fueled vehicles (AFVs) used for non-law enforcement purposes. The FBI has purchased and is using ten AFVs in its Oklahoma City, Denver, and Washington, DC, Field Offices and three additional AFVs for the Criminal Justice Information Services complex in Clarksburg, West Virginia.

\section{Environmental Activities}

DOJ's Transportation Coordinator serves on both the Transportation Demand Management Association and the Interest and Commuter Connections, which are programs designed to promote ride-sharing. The program's main thrust is to reduce traffic, pollution, and to promote high occupancy vehicle usage through positive actions and publicity.

\section{Energy Management Contact}

Mr. Warren Oser

Environmental Executive

U.S. Department of Justice

Main Justice Building, Room 1111

950 Pennsylvania Avenue, NW

Washington, DC 20530-0001

Phone: 202-514-0458

Fax: 202-616-6695 


\section{DEPARTMENT OF LABOR (DOL)}

\section{Energy Efficiency Performance and \\ Implementation Strategies}

In FY 1997, the Department of Labor reported a 1.6 percent decrease in buildings consumption in Btu per gross square foot compared to FY 1985.

\section{Labor Performance Toward Buildings Energy Reduction Goals}

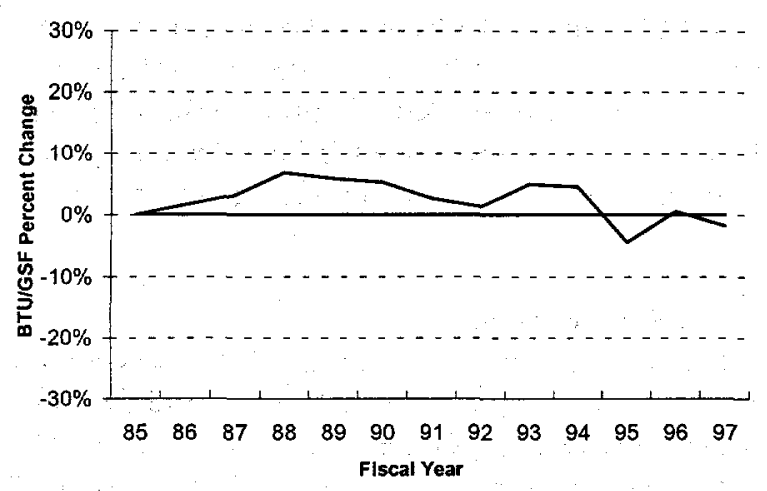

DOL Buildings Energy Use and Costs, FY97

$\begin{array}{lrr} & \text { BBtu } & \text { S(Thou.) } \\ \text { Electricity } & 794.6 & 15,535.3 \\ \text { Fuel Oil } & 226.3 & 1,207.3 \\ \text { Natural Gas } & 1,058.3 & 5,342.0 \\ \text { Propane } & 27.9 & 276.2 \\ \text { Purchased Steam } & 46.9 & 659.0 \\ & & \\ \text { Total } & 2,153.9 & 23,019.8\end{array}$

During FY 1996, DOL completed the development of a revised energy management plan for all DOL component facilities. The plan called for an aggressive program of audits, retrofits, and new construction through FY 2005, which would result in a 20 percent reduction in energy use DOL-wide from the FY 1985 baseline. The plan has been updated to reflect FY 1997 data, but the Executive Order 12902 mandated goal of a 30 percent reduction by FY 2005 continues to appear unrealistic due to the poor conditions of many Job Corps facilities. Because of these poor conditions, achieving the energy reduction goal would not be economically justified.

However, a myriad of energy improvements are ongoing as part of Job Corp's overall facility capital improvement program. These projects include:

- HVAC improvements;
- Lighting upgrades;

- Window replacements; and

- Building control system improvements.

An energy survey was performed in conjunction with an HVAC upgrade at the St. Louis Job Corps Center. Two applications were submitted to DOE for comprehensive facility audits funded through FEMP's SAVEnergy program. Due to its small size, one Center's application was turned down. However, the application for the North Texas Job Corps Center was approved, and site visits will occur in early FY 1998.

There is currently one Job Corps Center, San Diego, that utilizes solar power, for domestic water heating. It is planned that an existing non-functioning solar water heater at the Gary, Texas, Job Corps Center will be recommissioned.

DOL funded lighting retrofits at the Cassadaga Job Corps Center, New York, that were completed during FY 1997, and the retrofit at the Glenmont Job Corps Center was nearing completion. Both of these projects will begin producing energy savings in FY 1998. Payback for both retrofits should occur in less than five years.

DOL headquarters, at the Frances Perkins Building in Washington, $D C$, implemented the first stage of a major landscaping renovation plan designed to save water and energy (gasoline from mowers and other machinery). The gardens were replaced with grasses and other plants native to the area. Within three years, the rooftop gardens will be virtually maintenance-free.

The Frances Perkins Building also has an ongoing project to replace light switches with motion sensors. Energy-efficient motors for the HVAC system were also purchased and are being installed. In addition, the building's energy management system is being upgraded to link all the reheats and thermostats to the computerized system. These measures are expected to start producing energy savings in FY 1998.

DOL has signed on as a member of the Energy Procurement Challenge. During FY 1997, the Guide to Environmentally Preferable Procurement, which includes energy efficient procurement, was put on the DOL Intranet page. It is also available to DOL contractors and grantees through the Internet. 
Each year the Secretary of Labor presents awards to DOL employees, in ceremonies at headquarters and in the regions, for significant achievements accomplished in the past year. Major achievements in the energy reduction area can be recognized through this process by supervisors or by the energy management team.

\section{Energy Showcase Facilities}

The Frances Perkins Building has been designated as a showcase facility and has engaged in several promotional activities to show how it is saving energy. DOL was one of ten Federal agencies to participate in the DOE's "You Have the Power" campaign. A large "You Have the Power" banner was displayed over the building's front door, and a display was put up in the main lobby to highlight the various energy savings projects in the building.

\section{Training}

One Labor Department employee attended three DOE/FEMP training seminars on federal energy management, purchasing energy-efficient products, and energy savings performance contracts.

\section{Funding}

Job Corps has been evaluating several different options for the implementation of energy conservation projects. While direct agency funding remains the best, most effective method for completing projects, a variety of other methods have been examined.

Possible options include GSA's area-wide utility contracts, the DOE's Regional Super energy savings performance contracts (ESPCs), and the U.S. Army Corps of Engineers' ESPC program. To date, most efforts have been focused on DOE Regional ESPCs and the GSA area-wide contracts.

\section{Energy Savings Performance Contracts}

Job Corps is involved with a number of projects utilizing DOE's Regional Super ESPCs. Details follow:

- Gary Job Corps Center, Texas. The DOE Central Region chose the Gary facility as one of two Federal facilities to be included in their RFP solicitation. A delivery order will be issued for the Gary site one to two months following the award.

- Inland Empire/Sacramento Job Corps Centers, California. ERI Services has expressed interest in submitting a proposal for a "bundled" project. Verbal authorization has been given by DOE. However, ERI has expressed concern that the low value of the delivery order (less than $\$ 100,000$ ) may not be cost-effective. If a proposal is submit- ted and approved, a delivery order may be issued in mid FY 1998.

\section{Utility Partnerships}

Job Corps is working on two projects which utilize GSA area-wide contracts. These contracts allow energy conservation projects to be financed through local utility companies. Details follow:

- Kittrell Job Corps Center, North Carolina. Job Corps has received a proposal from Carolina Power \& Light for approximately $\$ 290,000$ of lighting, HVAC, and building envelope improvements. The projects would be self financing over a 10 year term.

- Pittsburgh Job Corps Center. Equitable Gas has performed a series of site visits. A project proposal to Job Corps has been submitted and accepted. A detailed site audit is in the planning stage, and indications suggest that HVAC and lighting upgrades will present the best opportunities for savings.

\section{Vehicles}

The DOL vehicle fleet consists of 4,013 GSA Interagency Fleet Management System vehicles, 182 agency-owned vehicles, six commercially leased vehicles, and an undetermined number of privately owned vehicles.

The number of alternative fuel vehicles (AFVs) remains at 7 percent. All AFVs are a part of the GSA IFMS group. Ninety percent of DOL's AFVs are flexible-fuel cars. The other 10 percent of AFVs are dedicated-fuel vans that use compressed natural gas.

\section{Energy Management Contact}

Ms. Jacqueline V. Wilson

U.S. Department of Labor

Room S-1521

200 Constitution Avenue, NW

Washington, DC 20210

Phone: 202-219-5205, ext. 126

Fax: 202-219-6886 


\section{DEPARTMENT OF STATE (ST)}

\section{Energy Efficiency Performance and Implementation Strategies}

In FY 1997, the Department of State reported an increase in buildings energy of 9.8 percent in Btu per gross square foot compared to FY 1985.

\section{State Performance Toward Buildings Energy Reduction Goals}

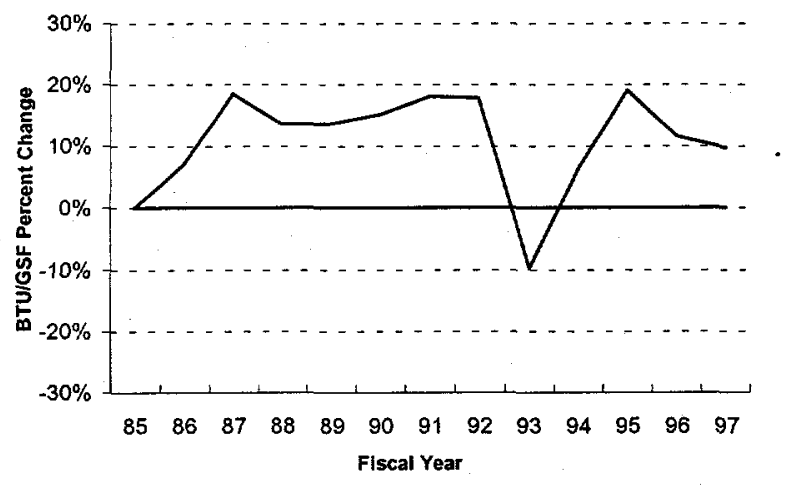

State Buildings Energy Use and Costs, FY97

$\begin{array}{lrr} & \text { BBtu } & \text { \$(Thou.) } \\ \text { Electricity } & 262.8 & 6,379.2 \\ \text { Fuel Oil } & 21.2 & 84.0 \\ \text { Natural Gas } & 53.5 & 327.2 \\ \text { Purchased Steam } & 0.0 & 14.0 \\ & & \\ \text { Total } & 337.5 & 6,804.4\end{array}$

In FY 1997, the Department of State continued to implement its Energy Management and Conservation Plan that was developed to meet the requirements and goals of EPACT and Executive Order 12902. The Energy Conservation Plan requires identification and implementation of cost effective energy conservation opportunities (ECOs) wherever practicable. The Department developed an integrated facilities management program and associated Energy Conservation Form to collect construction/alteration data utilized by State Department estimators and designers.

Efforts in FY 1997 resulted in a 13 percent reduction from FY 1996 energy consumption levels for comparative building loads. By implementing ECOs and operating the facilities under energy efficient standards, energy consumption will continue to decline. Details of State Department energy consumption patterns continue to be carefully monitored and are recorded monthly in the utility consumption charts.
In FY 1997, the State Department conducted three energy/audits. Each manager has developed an plan to complete ECOs identified from those audits.

Eleven buildings completed energy projects during FY 1997. Most projects focused on lighting upgrades to T8 fluorescent tubes, reflectors and electronic ballasts, and replacement and/or upgrades to energy-efficient motors. Projects also included variable-speed controllers, more efficient heat pumps, insulation, and upgraded exit lights. Weatherization, photovoltaics, HVAC controls, and better maintenance schedules for more optimum energy efficient operation have also been accomplished.

The State Department Office of Foreign Buildings Operations (FBO) completed energy surveys for buildings in Ankara, Bangkok, Dakar, Frankfurt, Geneva, London, San Jose, San Salvador, Tel Aviv, and Vienna. Abbreviated surveys, focusing only on utility rate analysis and energy metering, were completed in Brasilia and Caracas.

FBO purchased an energy accounting program to facilitate storage and manipulation of energy billing and energy use data collected from overseas posts.

Due to the nature of the building inventory, most audits have been simplified walk-through surveys of State Department warehouse facilities. However, the State Department is conducting more complex survey/audits with program personnel in office facilities with 40,000 to 85,000 square feet.

Adherence to energy efficiency standards is routinely noted in architectural/engineering (A/E) contracts for new construction. The A/E firm's compliance with energy efficiency requirements is reviewed and monitored as part of the normal design and construction review process.

\section{Energy Showcase Facility}

The State Department has selected the National Foreign Affairs Training Center in Arlington, Virginia, as its showcase facility. An ESPC procurement is planned, which will include renewable energy technology, if practicable, and new lighting technology incorporating a microwave energy source.

\section{Training}

The Department's building management employees continue to be trained in energy management principles and practices and are encouraged to implement and maintain appropriate operating standards and guidelines. Training of Department building managers in 
energy management principles and practices, across the broad range of mechanical and electrical fields, has helped to promote the identification of ECOs.

\section{Funding}

The basic approach of the State Department's energy retrofit program is to prioritize and survey buildings and facilities for all reasonable ECOs, not to perform expensive comprehensive audits on all properties, and to apply new technologies. The results of these surveys are categorized by cost-effectiveness, practicality of accomplishment, and then implemented as timing and funds are available.

Funding requests for energy conservation retrofit and capital equipment replacement are included in the State Department's budget process. Projects are prioritized in order of emergency, life and fire safety, mission, operation, and maintenance necessity. Consideration is given to life-cycle cost effectiveness, equipment condition, and savings-to-investment ratio.

\section{Energy Savings Performance Contracts}

The ESPC at Beltsville (Maryland) Information Management Center (awarded in FY 1996) provided energyefficient lighting with reflectors, LED exit signs, occupancy sensors, and variable-speed drives on chilled water pumps. Installation continued throughout FY 1997 , including additional variable-speed drives and testing of an ultrasonic humidification unit in the computer room HVAC units. After 16 months, the entire project cost, $\$ 54,602$, was paid through realized energy savings.

The relamping ESPC at the Main State Building was 95 percent complete in December 1996. The scope of the work included the installation of energy-efficient lighting, reflectors, and new lenses throughout the New State section of the Main State building. Eighty percent of eight-foot tandem, four-lamp fixtures were retrofitted with one electronic ballast, two reflectors, two lenses, and two tubes. This produced nearly a 67 percent reduction in energy consumption and a 34 percent illumination increase. Other retrofitted fixtures averaged reduced energy consumption of 50 percent. Annual energy savings are projected to be 5,111 megawatt hours per year, representing an annual cost saving of $\$ 464,278$.

\section{Utility Partnerships}

As part of its payment, the Beltsville Information Management Center ESPC contractor received a $\$ 32,700$ rebate from Potomac Electric Power Company's Custom Rebate Program. This was $\$ 27,500$ less than the $\$ 60,230$ originally expected. As a result, the Department opted to pay the contractor in full, avoiding excessive interest charges, which would have negated cost savings for about three years.

Difficulties in implementing energy projects have arisen during FY 1997 due to the loss of rebate incentives from utility companies.

\section{Vehicles}

The Department is participating in the DOE Alternative Fuel Vehicle Five-Year Acquisition Plan Program. The Department is also utilizing alternative fueled vehicles obtained through the GSA Interagency Fleet Management System lease program.

The Department also commits energy and resources to promote ride sharing and the use of public transportation. An active employee education program has been initiated, stressing the roles and responsibilities leading to energy conservation of every employee when operating vehicles.

\section{Environmental Activities}

The Department is scheduled to have non-CFC refrigeration machines installed by the GSA in the near future, in conjunction with the first phase of the Main State building renovation. Other operating equipment that use CFC refrigerants will be phased out depending on the availability of funds.

The Department has one of the most successful Federal recycling programs in the Washington Metropolitan Area. The Department recycles paper, glass, cardboard, aluminum and steel cans, construction debris, and toner cartridges. All light tubes and ballasts were recycled by the ESPC contractor in accordance with hazardous waste removal standards and procedures. Additionally, oils, solvents, and paints are recycled in accordance with EPA hazardous waste collection guidelines.

\section{Energy Management Contact}

Mr. Richard T. Arthurs

Energy Manager

Facilities Management and Support Services

Department of State

A/OPR/FMSS

$2201 \mathrm{C}$ Street, NW

Washington, DC 20520

Phone: 202-647-8970

Fax: 202-647-1873 


\section{DEPARTMENT OF TRANSPORTATION (DOT)}

Energy Efficiency Performance and

Implementation Strategies

During FY 1997, the Department of Transportation reported a 19.5 percent reduction in buildings consumption in Btu per gross square foot compared to FY 1985.

\section{DOT Performance Toward} Buildings Energy Reduction Goals

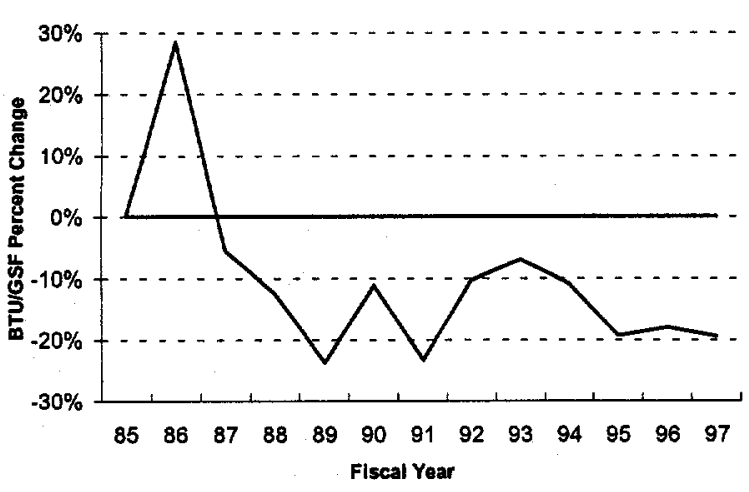

DOT Buildings Energy Use and Costs, FY97

$\begin{array}{lrr} & \text { BBtu } & \text { \$(Thou.) } \\ \text { Electricity } & 2,321.0 & 45,651.5 \\ \text { Fuel Oil } & 661.7 & 4,434.0 \\ \text { Natural Gas } & 786.9 & 3,888.3 \\ \text { Propane } & 8.8 & 110.0 \\ \text { Purchased Steam } & 21.7 & 278.5 \\ & & \\ \text { Total } & 3,800.1 & 54,362.3\end{array}$

The eight operating administrations that operate facilities and the Transportation Administration Service Center (TASC) all have active energy and water efficiency programs. The U.S. Coast Guard (USCG) is the largest user of reportable building and facility energy in the DOT. In FY 1997, a new Commandant Instruction, laying the foundation for the current energy program, was issued.

The Federal Aviation Administration (FAA) issued Order 1053.1A, Energy and Water Management Program for FAA Buildings and Facilities, in December 1996. This order commits the FAA to consider energy and water conservation measures in all agency activities.

Some notable energy surveys and energy conservation measures completed in FY 1997 are listed below:
- The TASC completed the installation of occupancy sensors in 1,800 offices in the DOT headquarters building. Approximately 75 percent of the lighting fixtures now have occupancy sensors.

- The FAA completed 13 audits in FY 1997. Approximately 100 energy conservation measures were investigated for cost and payback period. Lighting upgrades and air conditioning chiller upgrades were the two most frequently occurring energy conservation measures noted.

- Renovation of the Air Navigation Facility \#1 at the Mike Monroney Aeronautical Center, Oklahoma, was completed in 1997. All electrical and mechanical equipment was replaced with more energy efficient equipment. All glass was replaced with insulated glass. Roof and wall insulation was increased. Computer simulation predicts a 33 percent reduction in energy consumption over 1985 usage.

- The Federal Highway Administration continued its \$6.5 million renovation of the Fairbanks Building in McLean, Virginia. This included a new variable air volume HVAC system, roof insulation, and window/door replacement.

- The Maritime Administration has continued to make improvements at the Merchant Marine Academy at King's Point, New York. In FY 1997, new roofs, windows, and doors were installed.

Operation and maintenance procedures are decentralized within the Department. Basic procedures at facilities include securing HVAC equipment, unnecessary lighting, and office equipment during unoccupied hours. The FAA even reduced airport and runway lighting when it did not compromise safety of aircraft operations.

During FY 1997, audits of over 3 million square feet of space were completed. Over $\$ 8$ million in projects have been identified in over 11 million square feet where audits have been completed. The USCG has completed SAVEnergy audits at eight major facilities, representing approximately one-third of USCG space.

USCG is continuing efforts to secure approval for a 280-unit solar hot water project for residential units in Hawaii. Financial and technical support is being provided by DOE and the National Renewable Energy Laboratory. 
The FAA has installed photovoltaic panels as the primary power source at 21 remote communication links in the Western Pacific Region. Photovoltaic technology was also installed at beacons for the Instrument Landing System at Guam. An additional 268 remote communication sites may eventually be scheduled for this technology.

DOT agrees to purchase "best practice" products that are practical and cost-effective and in the upper 25 percent of energy and water efficiency. The FAA has provided each of its energy managers, purchasing agents, and contracting officers with the DOE FEMP publication Buying Energy Efficient Products.

\section{Energy Showcase Facilities}

Because fewer than five buildings are constructed each year, DOT is not required to identify a new building showcase. However, USCG is actively engaged in the development of eight Energy Star Buildings that will become showcase buildings once projects have been completed.

DOT's headquarters building was chosen as an existing building showcase in 1995. Energy improvements help avoid $\$ 1$ million in costs each year. Projects include retrofitting lights, installing occupant sensors, LED exit lights, more efficient window air conditioning units, and an energy management control system.

\section{Training}

The USCG conducted two energy training workshops attended by approximately 80 facility engineers in FY 1997. The first focused on the EPA Energy Star Program, while the second provided computer training with DOE's ASEAM building energy modeling program.

FAA Airway Facilities invested $\$ 22,200$ to train 40 people on various aspects of energy management. FAA plans to provide its energy managers the Energy Managers Training Course offered by the Association of Energy Engineers. Also, all FAA energy managers attended a DOE workshop in February 1997 which provided training on how to establish and administer an energy savings performance contract.

\section{Funding}

DOT has had to leverage funding to accomplish surveys and audits. The USCG and FAA have both used the DOE FEMP SAVEnergy program and utility company incentive programs, as well as in-house staff, to perform surveys.
A portion of the USCG operations and maintenance account has been set aside to fund energy projects costing less than $\$ 25,000$.

The total energy conservation measures backlog in the FAA is currently about $\$ 2$ million. Approximately $\$ 755,000$ from the energy program was budgeted during FY 1997 for energy conservation measure implementation.

\section{Energy Savings Performance Contracts}

The implementation of ESPCs is decentralized within DOT. There are several ESPCs nearing award. The Research and Special Programs Administration has developed an ESPC to install an energy management system and new lighting at its Cambridge, Massachusetts, research facility.

The USCG and FAA each have facilities that are participating in DOE's Western Region Super ESPC. USCG has offered its Air Station in Cape Cod, and its Support Center in Elizabeth City as pilot ESPC sites for the Northeast and Mid-Atlantic Regional Super ESPCs.

\section{Utility Partnerships}

The availability of utility incentives is becoming very limited. The O'Hare Air Traffic Control Tower has an agreement with Commonwealth Edison for a reduced stand-by generator rate that will save approximately $\$ 24,000$ per year. The Crossroads Systems Management (SMO) Office renewed a load shedding contract with Indianapolis Power and Light, saving around $\$ 8,800$ per year. A Chiller II modifications agreement with Northern States Power will save around \$12,500. The Minneapolis SMO has an agreement with Northern States Power to operate generators on standby that saves approximately $\$ 40,000$ per year.

\section{Environmental Activities}

The FAA has established an energy and water conservation category within their Environmental Excellence Award Program. The USCG has developed a similar incentive program.

\author{
Energy Management Contact \\ Mr. George Kuehn \\ Administrative Services Policy Division \\ U.S. Department of Transportation \\ 4007 th Street, SW \\ Washington, DC 20590 \\ Phone: 202-366-4243 \\ Fax: 202-493-2006
}




\section{DEPARTMENT OF THE TREASURY (TRSY)}

\section{Energy Efficiency Performance and \\ Implementation Strategies}

During FY 1997, the Department of the Treasury reported a 51.1 percent increase in buildings consumption in Btu per gross square foot compared to FY 1985.

\section{Treasury Performance Toward Buildings Energy Reduction Goals}

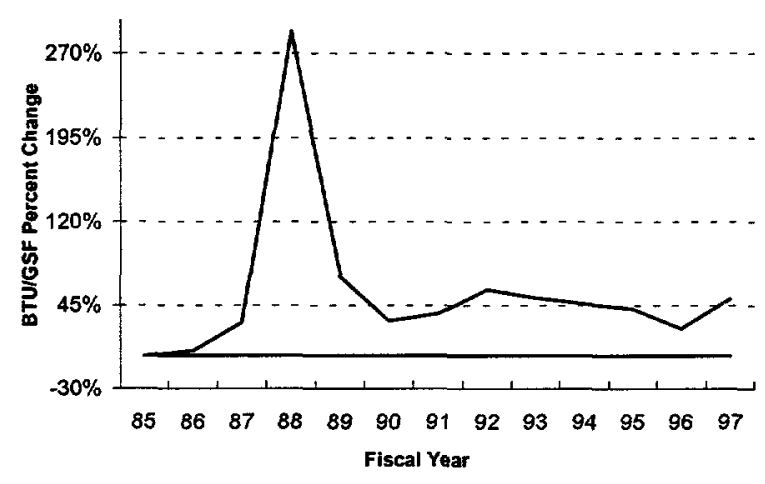

Treasury Buildings Energy Use and Costs, FY97

$\begin{array}{lrr} & \text { BBtu } & \text { \$(Thou.) } \\ \text { Electricity } & 1,194.1 & 23,625.1 \\ \text { Fuel Oil } & 53.4 & 271.1 \\ \text { Natural Gas } & 569.3 & 2,357.6 \\ \text { Propane } & 3.7 & 40.0 \\ \text { Purchased Steam } & 84.0 & 1,054.0 \\ & & \\ \text { Total } & 1,904.4 & 27,347.8\end{array}$

The Treasury Department's energy program is implemented at the Bureau level. Accordingly, each of the 12 Treasury Bureaus has developed an energy program that supports the requirements of the Energy Policy Act and Executive Order 12902. All Bureaus are committed to achieving a 30 percent reduction in energy use at their buildings and facilities by 2005 . Industrial facilities at the Bureau of the Mint and the Bureau of Engraving and Printing are working toward their 20 percent goal.

The Bureaus' energy management plans emphasize:

- Participation in public utility company incentive programs;

- Training for energy managers and related personnel;
- Using alternative financing such as energy savings performance contracting; and

- Expanding the use of alternative fuel vehicles.

The following are energy and water savings projects performed during FY 1997:

- The Internal Revenue Service's Andover Service Center, Massachusetts, continued its upgrade program. A new 250-ton chiller was installed, which is expected to yield a 234,000 -kilowatthour-per-year energy savings, a lighting retrofit was carried out, and 70 nine-year-old photocopiers were replaced with Energy Star compliant models. In FY 1998, Andover expects to remove from service two mainframe computers and all supporting equipment for an additional 200 kilowatt hour reduction.

- At the Fallon Federal Building in Baltimore, where the IRS is the primary occupant, GSA is replacing chillers and retrofitting the lighting.

- The Ogden Service Center has installed new cooling towers, variable-speed tower fans, and heat exchangers. Cost savings of $\$ 75,000$ to $\$ 90,000$ per year are expected.

- The Atlanta Service Center completed a lighting retrofit, installed occupancy sensors, and replaced restroom faucets with sensor-type faucets.

- The Cincinnati Service Center installed a new chiller plant with free cooling capabilities and a new cooling tower.

- The Office of Thrift Supervision installed a new heat exchanger, a new cooling tower, and replaced pneumatic control devices, pump motors, bearings, and seals.

- The Financial Management Services installed water-conserving faucets at its headquarters building and retrofitted its lighting.

- At the Birmingham Regional Financial Center, GSA started a major renovation, including lighting, building envelope, and HVAC upgrades.

- The Federal Law Enforcement Training Center in Glynco, Georgia, continued to implement a lighting upgrade. 
- Treasury is committed to buying products in the top 25 percent of energy efficiency. All computers, monitors, printers, and copiers purchased by Treasury are Energy Star compliant.

\section{Training}

Treasury supports and strongly encourages the Bureaus to develop effective training programs for their energy managers and facility energy coordinators. During FY 1997, eight Treasury employees attended energy management training courses, including those sponsored by DOE's Federal Energy Management Program.

\section{Funding}

Treasury Bureaus spent $\$ 3$ million installing energy and water conservation measures during FY 1997. This figure does not reflect GSA's expenditures in buildings delegated to Treasury. Anticipated savings from the FY 1997 investment total $\$ 352,000$ per year.

The Bureaus plan to spend $\$ 703,000$ to implement energy efficiency measures in FY 1998, the bulk of which will be at the Main Treasury building and IRS facilities.

\section{Energy Savings Performance Contracts}

Treasury Bureaus implemented their first two ESPCs in FY 1997. Details follow:

- The US Secret Service implemented an ESPC at their Beltsville, Maryland, training facility. The ESPC with Washington Gas covered converting the existing heating plant from oil to natural gas. Savings from the conversion are expected to be $\$ 15,000$ annually.

- The Bureau of the Mint implemented an ESPC with Honeywell at the Philadelphia Mint. The \$2.4 million contract included lighting retrofits, chiller replacement, HVAC upgrades, and upgrading the compressed air system. Anticipated savings are 2,440 megawatt hours per year and 2.2 million gallons of water per year. Installation will be complete in the second quarter of FY 1998.

In FY 1998, Treasury expects to enter into three more ESPCs. The Secret Service anticipates a lighting retrofit ESPC at its Beltsville facility. The Bureau of the Mint expects to enter into two more ESPCs for chiller replacement, lighting retrofit, and compressed air equipment upgrades at their Denver and San Francisco facilities.

\section{Utility Partnerships}

The IRS's Andover Service Center received a $\$ 21,000$ rebate for its retrofits and a $\$ 3,750$ credit for participation in the Performance Interruptible Credit Program run by Massachusetts Electric.

\section{Vehicles}

The Bureaus have implemented driver awareness programs aimed at getting their employees to drive in the most fuel-efficient manner possible. Bureaus continue to eliminate vehicles wherever possible and request the smallest class of vehicle which will still accommodate the mission.

Treasury continues to slowly expand its alternative fuel vehicle fleet; however, the loss of DOE funds for vehicle conversion has hurt this effort.

Treasury continues to support an incentive program aimed at getting employees to use public transportation whenever possible. A telecommuting policy is in development, allowing work from home or satellite locations, thereby reducing the number of vehicles on the road.

\section{Environmental Activities}

CFCs removed from old equipment are recovered and turned over to the Defense Logistic Agency CFC bank. Several Bureaus are now specifying the new lowmercury lamps in all purchases, thereby reducing the amount of hazardous waste generated at their facilities.

\author{
Energy Management Contact \\ Mr. Bill McGovern \\ Environment and Energy Programs Officer \\ Department of the Treasury \\ $1310 \mathrm{G}-400$ West \\ 1500 Pennsylvania Ave., NW \\ Washington, DC 20220 \\ Phone: 202-622-0043 \\ Fax: 202-622-1468
}




\section{DEPARTMENT OF VETERANS AFFAIRS (VA)}

Energy Efficiency Performance and Implementation Strategies

During FY 1997, the Department of Veterans Affairs reported a 13.2 percent reduction in buildings consumption in Btu per gross square foot compared to FY 1985.

VA Performance Toward Buildings Energy Reduction Goals

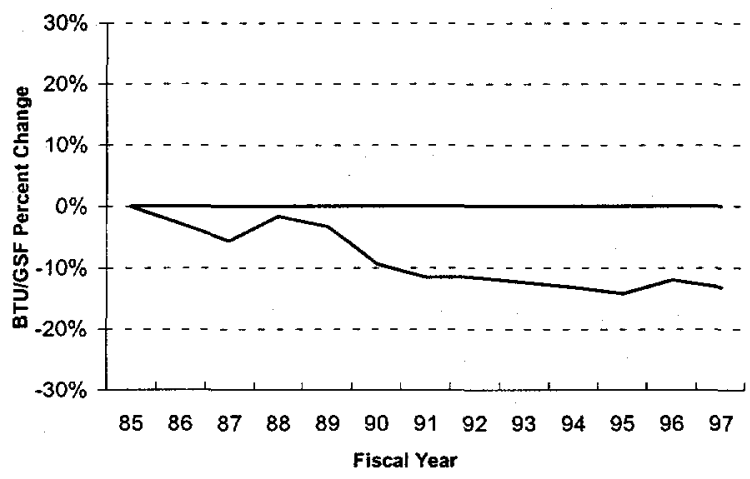

VA Buildings Energy Use and Costs, FY97

$\begin{array}{lrr} & \text { BBtu } & \text { \$(Thou.) } \\ \text { Electricity } & 9,116.7 & 157,136.8 \\ \text { Fuel Oil } & 1,181.7 & 5,788.2 \\ \text { Natural Gas } & 14,240.8 & 54,734.7 \\ \text { Propane } & 4.6 & 38.2 \\ \text { Coal } & 150.2 & 161.9 \\ \text { Purchased Steam } & 1,229.0 & 9,398.8 \\ \text { Other } & 139.0 & 588.8 \\ & & \\ \text { Total } & 26,062.0 & 227,847.4\end{array}$

In order to meet the requirements of NECPA, EPACT, and Executive Order 12902, the Department of Veterans Affairs developed a 13-year plan for FY 1993 to FY 2005.

As part of the VA's plan, each medical center has been assigned a target energy consumption goal in Btu per square foot for FY 2005. They are monitored regularly by the Energy Management Division, which publishes its findings every quarter in the Energy Management and Control Quarterly Report that is distributed to each medical center.

During FY 1997, the VA has continued to concentrate heavily on research for and the development of costeffective approaches such as utility rebate programs and energy savings performance contracts (ESPCs) to reduce overall electrical consumption and associated costs. Increased demands to satisfy the needs of modern medical care have resulted in an increase of electrical consumption of 25.9 percent compared to consumption in the FY 1985 base year. The following methods have been implemented to offset this increase:

- Design criteria for all new construction and retrofit projects were revised to include the use of the most energy-efficient lighting fixtures.

- Energy management and control systems with direct digital controls are specified as part of new construction and retrofit of HVAC systems.

Building retrofit projects under way at VA facilities include the installation of energy management control systems, modifications of the existing HVAC systems, steam trap replacement, improvement of boiler efficiency and lighting and power systems, installation of additional insulation and storm windows, and water conservation projects.

The following projects have been completed in FY 1997:

- VA Medical Center, Lake City, Florida, completed the retrofit of lighting fixtures throughout its facility;

- VA Medical Center, Dallas, Texas, completed the installation of a thermal water storage system;

- VA Medical Center, Richmond, Virginia, completed the installation of cooling towers; and

- VA Medical Center, Portland, Oregon, completed the retrofit of about 10,000 lighting fixtures, 500 exit signs, and 800 occupancy sensors.

\section{Training}

In FY 1997, many VA medical center engineering staff members participated in classes offered by the Association of Energy Engineers and by DOE's Federal Energy Management Program.

\section{Funding}

Approximately $\$ 7.4$ million was allocated for energy conservation retrofits and capital improvements in FY 1997. In the upcoming year, the VA plans to fund costeffective projects that have been approved by the Veterans Integrated Service Network for implementation at medical centers. 


\section{Energy Savings Performance Contracts}

The VA completed its first energy savings performance contract in FY 1993. The energy savings have proven to be accurate, and the Medical Center is very satisfied with the performance of the contractor.

The following Veterans Integrated Service Networks (VISNs) have signed Memoranda of Agreement with the U.S. Army Corps of Engineers, Engineering and Support Center, Huntsville, Alabama, for the various services they offer under their ESPC program:

- VISN 5, with five medical centers;

- VISN 6, with eight medical centers; and

- VISN 8, with seven medical centers.

\section{Utility Partnerships}

The VA has partnered with the Southern California Edison Company to develop an electricity saving program at the West Los Angeles VA Medical Center. The project will replace lighting and air conditioning equipment with more efficient systems. All project costs will be paid from savings in electricity resulting from the new equipment. While the agreement is not an ESPC, the endeavor replaces inefficient equipment and requires no capital expenditure by the agency.

The VA also owns, operates, and maintains one cogeneration plant. VA is evaluating the effectiveness of thermal storage systems (water or ice) at many medical centers. The VA has completed such projects at Charleston, South Carolina, and Dallas, Texas, with incentives from local utility companies.

\section{Energy Management Contact}

Mr. Rajinder P. Garg

Chief, Energy Management Division (138C1)

U.S. Department of Veterans Affairs

Room 417-LAF

810 Vermont Avenue, NW

Washington, DC 20420

Phone: 202-273-5843

Fax: 202-273-6298 


\section{ENVIRONMENTAL PROTECTION AGENCY (EPA)}

\section{Energy Efficiency Performance and \\ Implementation Strategies}

In FY 1997, the Environmental Protection Agency reported a decrease in buildings energy of 11.3 percent in Btu per gross square foot compared to FY 1985.

\section{EPA Performance Toward Buildings Energy Reduction Goals}

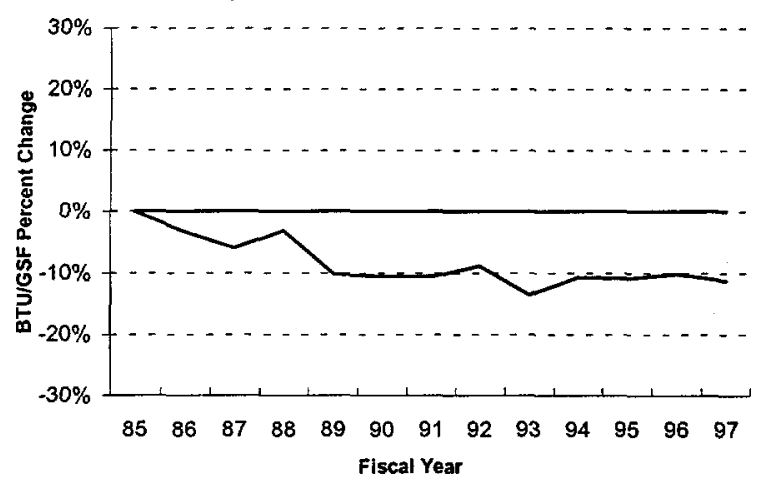

EPA Buildings Energy Use and Costs, FY97

$\begin{array}{lrr} & \text { BBtu } & \text { \$(Thou.) } \\ \text { Electricity } & 438.0 & 7,017.3 \\ \text { Fuel Oil } & 25.5 & 124.6 \\ \text { Natural Gas } & 515.8 & 2,329.2 \\ \text { Propane } & 0.6 & 8.8 \\ \text { Purchased Steam } & 31.5 & 262.7 \\ & & \\ \text { Total } & 1,011.5 & 9,742.6\end{array}$

The main objective of EPA's Energy and Water Conservation Program is to effectively and efficiently use natural resources when designing, constructing, and maintaining the agency's facilities and facility systems. The program is committed to reduce energy consumption by upgrading existing HVAC systems with nonCFC technologies, and by incorporating innovative energy-efficient and renewable technologies where feasible.

While striving to implement this program, EPA has learned that its largest energy conservation opportunity is within the HVAC systems of its laboratories. Due to energy-intensive health and safety requirements for onepass air for a laboratory, EPA's energy consumption is extraordinarily high.

EPA's strategy for achieving the 20 percent reduction goal by 2000 is to incorporate energy-efficient HVAC technologies in all of EPA's most energy-intensive laboratories. The 30 percent reduction by 2005 will be met by installing automated control systems to monitor and adjust those technologies so that they run at the most efficient levels, and by conducting energy upgrades at other facilities.

EPA visited six of its laboratories in FY 1997 to assess and monitor existing energy-intensive mechanical equipment and energy management practices, and to evaluate conservation opportunities. Details of the site visits are listed below:

- Ada, Oklahoma. Developed a strategic energy monitoring plan to determine a facility baseline. Conducted an energy audit. Installed monitoring equipment. Conducted a technical analysis of a ground source heat pump application.

- National Vehicle and Fuel Emissions Laboratory (NVFEL), Ann Arbor, Michigan. Helped develop data to provide better understanding of energy consumption.

- Andrew W. Breidenbach Environmental Research Center (AWBERC), Cincinnati, Ohio. Conducted assessment of energy conservation opportunities. Discussed potential demonstration project, including heat pipe and indirect evaporative cooling technologies.

- Edison, New Jersey. Assessed operation of existing desiccant dehumidification system. Provided recommendations for use of solar hot water system.

- Gulf Breeze, Florida. Installed monitoring equipment. Linked the air conditioning system of a newly renovated building to an oversized chiller in an adjacent building, saving both renovation costs and energy consumption.

- Narragansett, Rhode Island. Conducted comprehensive energy audit. Conducted technical analysis of a geothermal source heat pump application as the foundation of a comprehensive energy upgrade.

In FY 1998, EPA anticipates visiting the following laboratories to assess energy savings opportunities: Ada, Oklahoma; Ann Arbor, Michigan; Athens, Georgia; Duluth, Minnesota; Edison, New Jersey; Gulf Breeze, Florida; Manchester, Washington; Narragansett, Rhode Island; and Richmond, California. 
Throughout FY 1997, EPA continued to provide technical support to ongoing projects, incorporating new innovative technologies, and planning for future energy upgrades. Some details of these projects are below:

- Ada, Oklahoma. A ground source heat pump system will soon be installed.

- NVFEL, Ann Arbor, Michigan. An ESPC to conduct a complete energy upgrade will be awarded in FY 1998. A photovoltaic energized active daylighting system was installed to provide natural lighting in a high-bay area. NVFEL's energy conservation efforts last year saved $\$ 45,000$ in utility bill costs. FY 1997 also saw NVFEL break ground on its new energy efficient office building. Target date for completion is March or April 1998.

- Athens, Georgia. A biomass feasibility study is under way. A partnership between the EPA, DOE, Tennessee Valley Authority, USDA, University of Georgia, and Georgia State Forestry will be the foundation of this project. Also, a solar hot water system was installed at the day care center.

- Duluth, Minnesota. Green Lights lighting projects were incorporated and energy efficient windows were installed. Geothermal cooling is being used.

- Edison, New Jersey. A combination desiccant wheel/heat transfer system has been installed as a pilot program at the laboratory to recover energy from fume hood exhausts and to control humidity and conditioning in analytical chemistry laboratory modules. A statement of work is in place to install a solar hot water heating system.

- New EPA Headquarters, Washington, DC. Many energy-efficient and productivity-promoting HVAC and lighting features were incorporated into the design.

- Fort Meade Environmental Science Center, Fort Meade, Maryland. EPA, with DOE and DOD, assembled a public-private partnership to potentially demonstrate the world's first megawatt- class solid oxide fuel cell power station.

- Gulf Breeze, Florida. Heat pipe technology has provided realized reductions in the existing DX cooling system by precooling and dehumidifying outside supply air in the analytical laboratory building. Timers have been installed on 20 electric water heaters, saving significant amounts of en- ergy. In FY 1998, a photovoltaic system will be installed to generate on-site electricity.

- Houston, Texas. A cooling tower condensate return system was installed to reduce water consumption, reduce operating costs, and enhance environmental conditions.

- Narragansett, Rhode Island. EPA is designing an HVAC system upgrade which will use high efficiency chillers, geothermal heat pumps, and latent energy recovery technologies.

- Research Triangle Park, North Carolina. The Environmental Research Center has installed energy-efficient lights, chillers, air compressors, and vacuum pumps.

In FY 1997, EPA established a relationship with the Corporation for Solar Technology and Alternative Renewable Resources (CSTRR), a public corporation charged with developing and distributing solar and renewable energy. This is to incorporate the use of purchased solar energy at the EPA's Las Vegas laboratory.

\section{Training}

EPA participated in, and hosted, numerous training events during FY 1997. Product demonstration seminars and trips with various vendors were arranged for EPA's engineers, architects, and facility managers to encourage use of proven innovative technologies.

EPA's Office of Administration, in cooperation with Lawrence Berkeley National Laboratory and the National Renewable Energy Laboratory, has instituted a semi-annual conference entitled Laboratories for the 21 st Century for agencies pursuing energy upgrades in Federal laboratories. The first conference was held in Washington, DC, in September 1997. The second is scheduled for May 1998, in San Francisco, California.

EPA hosted its annual national conference to provide training to EPA employees responsible for facility management, operations, and safety. Sessions on energy and water conservation, pollution prevention, and environmental regulatory compliance were presented. The session on energy conservation focused on several subjects, including efforts to implement ESPCs, energy flows within laboratory environments, and integration of energy-efficient technologies.

\section{Funding}

For FY 1997, EPA's Energy and Water Conservation Program nationwide had a budget of approximately 
$\$ 1.6$ million. The budget for FY 1998 will be approximately the same.

\section{Energy Savings Performance Contracts}

EPA is aggressively developing an ESPC for the total energy upgrade project at the NVFEL. The ESPC will implement the principles of energy consumption reduction, pollution prevention both at the site and the source, maximizing the use of "waste free" energy, and the use of innovative and renewable technologies. Bids have been received, and EPA expects to provide an award in the spring of 1998.

NVFEL currently pays approximately $\$ 1.1$ million per year in energy costs. It is expected that the facility will realize at least a 30 percent annual reduction in energy consumption through the ESPC upgrade. EPA will use the NVFEL ESPC as a template for pursuing energy upgrades at its other facilities:

- Kerr Laboratory, Ada, Oklahoma. An energy efficiency upgrade through the incorporation of a geothermal heat pump is under consideration. The facility currently pays around $\$ 239,000$ per year in energy costs. Projections indicate savings of 30 percent would be possible through the use of an ESPC.

- The Narragansett, Rhode Island, laboratory is also is looking into the installation of a geothermal heat pump via an ESPC. The facility currently pays approximately $\$ 390,000$ per year in energy costs.

\section{Vehicles}

During FY 1997, EPA operated a total of 125 alternative fuel vehicles (AFVs): 101 methanol (M-85), 10 ethanol (E-85), 14 dedicated compressed natural gas (CNG), and one bi-fuel CNG. AFVs constitute 18 percent of all vehicles leased from GSA by EPA.

\section{Environmental Activities}

Posters illustrating the benefits of installing energyefficient HVAC systems and describing the ESPC process were displayed at the annual EPA buildings and facilities conference, the EPA headquarters in Washington, DC, and at the EPA Region VIII office in Denver, Colorado.

Through the DOE-sponsored "You Have the Power" campaign, EPA identified and recognized seven EPA employees for being energy champions. Promotional materials were developed for the campaign, including energy champion posters that highlighted the selected EPA individuals and their work; "Hometown Hero" newspaper articles describing them and their work; a large "You Have the Power" banner displayed at the
EPA headquarters for a month beginning on Earth Day, April 1997; and an industry partnership agreement to be issued upon award of the NVFEL ESPC.

The EPA newsletter Conservation News featured several energy awareness articles during FY 1997. Conservation News can now be accessed on the Internet.

In FY 1997, EPA distributed awareness packages to all facility and energy managers. The package included:

- A computer spreadsheet to track energy consumption, automatically develop quarterly consumption reports, graph energy usage, and calculate associated pollution generated;

- Tips to conserve energy on a daily basis;

- Computer screen savers to encourage energy conservation; and

- Posters with energy conservation related facts that employees can use to save energy.

\section{Energy Management Contact}

Mr. Philip Wirdzek

Facilities Management and Services Division

Mail Stop 3204

United States Environmental Protection Agency

401 M Street, SW

Washington, DC 20460

Phone: 202-260-2094

Fax: 202-401-8971 


\section{GENERAL SERVICES ADMINISTRATION (GSA)}

\section{Energy Efficiency Performance and Implementation Strategies}

In FY 1997, GSA reported a 13.5 percent decrease in energy consumed in owned and leased buildings compared to FY 1985 in Btu per gross square foot.

\section{GSA Performance Toward Buildings Energy Reduction Goals}

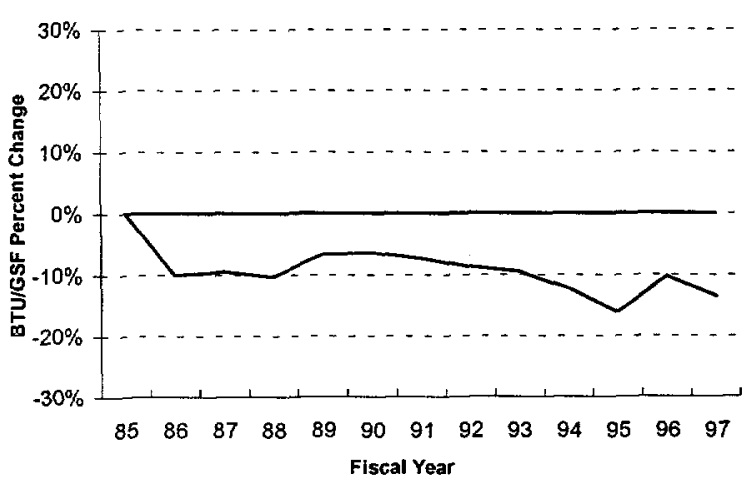

GSA Buildings Energy Use and Costs, FY97

$\begin{array}{lrr} & \text { BBtu } & \text { \$(Thou.) } \\ \text { Electricity } & 8,580.4 & 180,910.6 \\ \text { Fuel Oil } & 143.0 & 725.0 \\ \text { Natural Gas } & 3,225.0 & 16,286.5 \\ \text { Purchased Steam } & 1,405.2 & 21,452.7 \\ & & \\ \text { Total } & 13,353.7 & 219,374.8\end{array}$

GSA has implemented an Energy and Water Management Business Plan to reduce energy consumption by promoting optimal energy use while protecting the environment and ensuring a quality workspace for its clients. In FY 1997, GSA established an Energy Center of Expertise (ECOE) in Kansas City, Missouri, to implement this plan. The ECOE has a total of 19 members, five in the Kansas City headquarters, seven in the National Energy and Water Management Center (NEWMC) in Fort Worth, Texas, and seven in the Public Utilities Office in Washington, DC. Additionally, each of GSA's 11 regions contributes at least one associate to the ECOE.

GSA has recognized the opportunity for reducing costs and energy consumption with the onset of deregulation of the electric industry and increased availability of non-Federal financing for energy projects. A strategy has been developed to take advantage of this new environment. Inherent to this strategy is the need for flexibility in achieving both cost reduction and energy reduction and the institutionalization of life-cycle cost savings philosophy throughout the Public Building Service.

The GSA buildings energy program relies on six major strategies:

- Optimize utility management;

- Seize opportunities inherent in deregulation;

- Use innovative procurement methods;

- Enhance building operations efficiency;

- Partner to increase energy program leverage; and

- Expand energy program training.

GSA has a 10 year audit plan in place in which approximately 10 percent of all space is audited in any given year. The plan is updated every year. Comprehensive audits are performed, some by in-house personnel, some by energy savings performance contractors, and some by $\mathrm{A} / \mathrm{E}$ contractors. Audits performed in the past resulted in a large number of energy efficiency and water conservation projects during FY 1997. GSA currently has 92 projects under way as a result of funding received in FY 1997.

When GSA performs an energy audit of a facility, renewable opportunities are identified and implemented if they are cost-effective. In addition, the Facility Standards for Public Buildings (PBS PQ 100.1) incorporates language for solar/renewable energy sources to be considered in the proposed design.

The Corporation for Solar Technologies conducted an intergovernmental workshop cosponsored by GSA and DOE for State, local, and Federal governments and private utility companies in the state of Nevada. Also, GSA intends to award a solar installation project to a Honolulu Federal building using alternative financing from Hawaiian Electric under the GSA Public Utility area wide contract.

\section{Environmental Showcases}

In FY 1997, GSA designated four showcase facilities:

- The Hawthorne Federal Building in Hawthorne, California;

- Chet Holyfield Federal Building in Laguna Niguel, California;

- Tampa Federal Courthouse II in Tampa, Florida; and 
- Alexander Hamilton Customs House in New York, New York.

\section{Training}

GSA has fulfilled and exceeded the requirements of EPACT to hold five workshops (one in each standard Federal region over a two-year cycle) during the past fiscal year and has embarked on additional initiatives that promote the exchange of energy conservation technology between the Federal, State, and local governments and tribal communities.

In 1997, GSA held five workshops, including:

- Corporation for Solar Technologies Conference cosponsored with DOE and FEMP for target audience from State, local, and Federal agencies and private utilities in Nevada;

- Education on Tribal Community, Environmental and Building Issues Workshop with the Southwestern Tribal Commission in New Mexico;

- Energy Savings Performance Contracts Workshop for State energy professionals from Maryland, Virginia, and the District of Columbia;

- Cool \$ense Integrated Solutions to CFC Phaseout in Commercial Cooling Workshops cosponsored with Lawrence Berkeley Laboratory, DOE, and FEMP for State and private building owners, and Federal building and facility managers from Colorado and Massachusetts; and

- Energy Efficiency in Government Facilities Workshop cosponsored with the Washington Metropoli$\tan$ Council of Governments for energy professionals from Maryland, Virginia, and the District of Columbia.

GSA currently has on staff 28 certified energy managers and has incorporated energy management training into routine training of facility managers and facility management interns.

\section{Funding}

All GSA energy projects are selected based on lifecycle cost effectiveness. In FY 1997, GSA committed $\$ 20$ million to fund 92 energy projects nationwide, which produced $\$ 532,587$ in utility rebates.

Energy projects funded in FY 1997 represent the following types of work:

- lighting systems retrofits;
- installation of energy management and control systems;

- improvements in HVAC, boiler, and chiller control systems;

- improvement in building envelope thermal efficiency;

- increased insulation; and

- chiller replacement.

\section{Energy Savings Performance Contracts}

To date, GSA has entered into one energy savings performance contract. Johnson Controls is financing a \$1.6 million energy management control system upgrade in the Deconcini Courthouse and Federal Building in Tucson, New Mexico.

GSA has an additional 26 alternative financed projects scheduled for FY 1998 and FY 1999.

GSA's Northeast and Caribbean region signed a Memorandum of Understanding with DOE to establish a deliver order under the Northeast Regional Super ESPC. GSA designated the O'Brien Federal Building in Albany, New York for this project.

\section{Utility Partnerships}

The Public Utilities Team of the ECOE is developing contracting vehicles which enable GSA customers to procure utility services at the lowest cost to the taxpayer. Current emphasis is on the positioning of the Government to take advantage of potential cost savings which may be possible upon the restructuring of the electric industry.

Area wide contracts have been highly successful, with approximately 140 in effect. Area wides are master blanket contracts for public utility services. GSA area wide contracts spell out the general terms and conditions of utility service, contain all applicable Federal clauses, and provide instructions for Federal agency use. They provide simple, standardized procedures for ordering services. These various utilities are providing comprehensive energy audits of GSA-owned Federal buildings. The energy audits represent a significant cost saving to GSA, and they are currently being conducted on an expedited schedule using area wide utility contracts.

Utility rebate projects entered into during FY 1997 include:

- Hawaiian Electric financing a $\$ 4$ million energy retrofit at the Prince Kuhio Federal Building in Honolulu, Hawaii; 
- ENVEST-SoCal Edison financing a \$4.5 million energy retrofit at the Chet Holyfield Federal Building in Laguna Niguel, California;

\section{Vehicles}

GSA now has approximately 9,600 alternative fuel vehicles, representing 7 percent of its total fleet.

To conserve energy and to reduce pollution, GSA will have introduced telecommuting facilities for over 3,000 Federal employees by the end of FY 1998. It is estimated that the telecommuting program saves 6,000 passenger miles per Federal employee per year.

\section{Environmental Activities}

GSA's environmental activities include several internal and external conservation programs. The external programs include alternative fuel vehicles, energy savings programs, water conservation programs, procurement of recycled products, efficient packaging and shipping methods, alternative work sites, flex-time, and ridesharing.

In FY 1997, GSA's national recycling program recovered nearly 400,000 tons of material from the waste stream. The material was sold for almost $\$ 900,000$ and all moneys were returned to those Federal agencies participating in the program.
Internal programs include resource conservation, procurement and use of energy-efficient appliances, indoor air quality monitoring, and daytime cleaning.

GSA continues to provide product supply schedules that promote energy-efficient and environmentally preferable products, and to mandate the purchase of Energy Star computers and office equipment. GSA is a signatory and active participant in the "Procurement Challenge," a DOE and FEMP interagency program designed to identify the most energy-efficient products and to increase the purchase of these products.

GSA annually participates in the DOE Federal Energy and Water Awards program and received six awards at the November 1997 Awards. GSA internally honors each one of the DOE award recipients with a ceremony and a monetary award.

\author{
Energy Management Contact \\ Ms. Beth Shearer \\ 6PNE \\ General Services Administration \\ 1500 E Bannister Road \\ Kansas City, MO \\ Phone: 816-926-7232 \\ Fax: 816-9.26-5139
}




\section{NATIONAL AERONAUTICS AND SPACE ADMINISTRATION (NASA)}

\section{Energy Efficiency Performance and Implementation Strategies \\ During FY 1997, the National Aeronautics and Space Administration reported a 25.2 percent reduction in buildings energy consumption in Btu per gross square foot compared to FY 1985.}

\section{NASA Performance Toward Buildings Energy Reduction Goals}

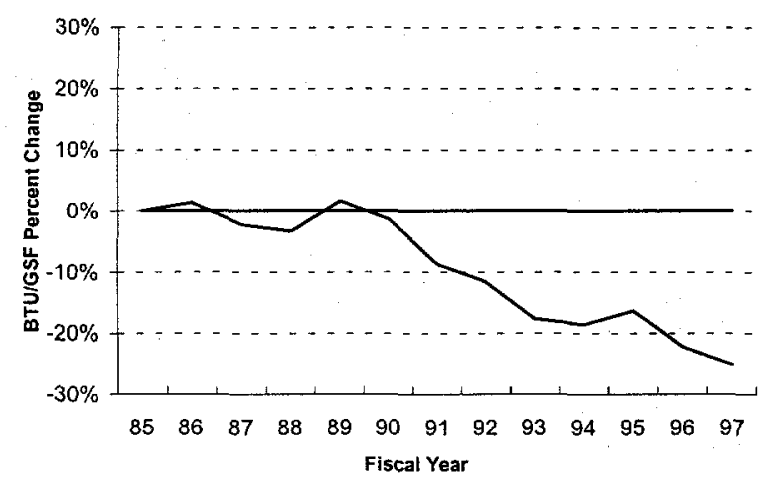

NASA Buildings Energy Use and Costs, FY97

$\begin{array}{lrr} & \text { BBtu } & \text { \$(Thou.) } \\ \text { Electricity } & 2,459.9 & 36,008.0 \\ \text { Fuel Oil } & 87.0 & 499.0 \\ \text { Natural Gas } & 1,298.1 & 5,151.0 \\ \text { Propane } & 6.2 & 54.0 \\ \text { Purchased Steam } & 73.9 & 973.0 \\ \text { Total } & & \\ & 3,925.0 & 42,685.0\end{array}$

NASA manages 10 major Centers in the United States, as well as other Component Facilities and overseas tracking stations. NASA revised its comprehensive Energy Conservation and Management Implementation Plan (ECMIP) in March 1994 as required by NECPA. The ECMIP is based on the Centers' 15 -year energy conservation plans and defines the agency's 10-part strategy to meet Federal energy goals.

From FY 1991 through FY 1997, NASA completed energy audits for 44.6 percent of its total building square footage.

Energy efficiency activities conducted by NASA Centers and Component Facilities fall under four main categories: surveys, metering, operation and maintenance procedures, and energy efficiency projects. The energy efficiency projects implemented or under way during FY 1997 are as follows:

- Two boilers were replaced at Dryden Flight Research Center (DFRC), which also received an interior lighting system upgrade. Annual savings are estimated at $\$ 25,000$, giving the project a three year payback.

- Goddard Space Flight Center (GSFC), Maryland, continued its lighting system upgrade through the EPA/DOE Green Lights Program. A Federal Energy Efficiency Fund project for lighting and HVAC system improvements in four buildings was also completed. Various projects to upgrade building HVAC systems and install direct digital control (DDC) systems were also implemented. GSFC is implementing multi-year projects to upgrade the Center's central chilled water distribution system and the central steam and condensate systems.

- Kennedy Space Center (KSC) continued a project expanding the Industrial Area Chiller Plant in order to consolidate chilled water generating capacity. Inefficient $\mathrm{CFC}$ refrigerant chillers will be replaced with high-efficiency chillers and variable-speed chilled water pumping systems. The new chillers are rated at 0.58 to 0.63 kilowatt (KW) per ton versus $0.97 \mathrm{KW}$ per ton for the old chillers, an increase in efficiency of 64 percent. Thermal optimization control valves and variablespeed pumps are also being used to reduce the amount of chilled water that must be circulated through the system.

- Lewis Research Center (LeRC), Cleveland, Ohio, completed major modifications to the Composite Technology Center. The scope of the $\$ 19$ million project included conversion of the heating system from steam to hot water, replacement of direct expansion air conditioning equipment with chilled water units, segregation of office and laboratory ventilation systems, segregation of the existing domestic water supply system into separate potable and non-potable water systems, high-efficiency motors and pumps, energy-efficient lighting system upgrades, and lighting occupancy sensors for offices, conference rooms, corridors, and bathrooms.

- Marshall Space Flight Center (MSFC), Huntsville, Alabama, has implemented one-third of the energy 
and water conservation measures identified in nonexempt facilities and 60 percent of similar measures in exempt facilities.

- Wallops Flight Facility (WFF) completed a lighting system upgrade for seven buildings. WFF has installed energy efficiency fluorescent lighting systems in 80 percent of its facilities. DDC systems were installed in three exempt and two nonexempt buildings, resulting in the control of 25 WFF buildings by the new energy management control system. Improvements in HVAC control, elimination of redundancy, control of intermittently occupied buildings, and streamlining of control strategies have all contributed to an overall reduction in the use of electric power for chilled water production and the consumption of heating oil.

- The Office of Space Communications complex reported an increase in mission efficiency from 0.88 tracking hours per megawatt hour (MWH) in FY 1985 to 3.24 tracking hours per MWH in FY 1997, an efficiency improvement of over 268 percent. This improvement is due in part to increased mission workload, but also to upgrading Deep Space Network communication equipment with modern, energy-efficient components.

- Langley Research Center (LaRC), Hampton, Virginia, began a major renovation of the National Transonic Facility in FY 1997 that will significantly improve the operational efficiency of the facility. This includes the installation of a new 135,000-horsepower variable-speed drive motor. LaRC also consolidated facilities serving the central compressed air utility system, leading to the shutdown of the East Area Compressor Station.

- Santa Susana Field Laboratory, California has implemented several changes that substitute recycled water for potable water and use timers and controls to avoid running water pumps during periods of high electrical demand. Savings from these process changes are estimated at $\$ 17,000$ per year.

- A $\$ 400,000$ project for energy efficiency improvements to the Ames Research Center Administration Building was implemented.

White Sands Test Facility (WSTF) is planning to award a contract in early FY 1998 for comprehensive energy and water audits of several facilities totaling approxi- mately 200,000 gross square feet. WSTF conducted a $\$ 6,800$ study to assess the condition of the water distribution piping in the 300 and 400 Areas. A CoF project has been requested for FY 2000 to replace piping runs that are deteriorated or prone to leaking.

\section{Energy Showcase Facility}

The Marshall Space Flight Center Project Engineering Facility, Building 4203, was designated as NASA's showcase facility. The facility features many state-ofthe-art energy efficiency and environmental quality measures, such as tinted windows, a variable air volume HVAC system, HCFC-123 chillers, an automated energy management system with direct digital controls, self-illuminating exit signs, and a radon venting system. The building is heated with steam from the Army's Redstone Arsenal steam distribution system, which is connected to the City of Huntsville's solid-waste-tosteam plant. A comprehensive audit of the facility identified additional energy and water conservation measures, including lighting upgrades and occupancy sensors, high-efficiency motors, variable-frequency drives for the air handling units and chilled water pumping system, water-saving devices, and operations and maintenance recommendations. The water conservation measures, funded through the Federal Energy Efficiency Fund, will be completed by early FY 1998.

\section{Training}

NASA contracted with the National Renewable Energy Laboratory to provide training in energy savings performance contracting procedures and water conservation technology at two agency-wide training sessions for NASA energy managers.

The Ames Research Center energy manager attended training on the deregulation of the California electrical power market, infrared thermography, and the use of precision laser alignment to reduce energy losses associated with misalignment of motors on shaft-driven equipment. The GSFC energy manager attended the Maryland Energy Administration's conference on municipal and cooperative aggregation in response to electric industry restructuring. One $\mathrm{LaRC}$ employee attended the DOE FEMP Life Cycle Cost/Energy Analysis course in Rockville, Maryland. The LaRC energy manager also joined the Hampton Roads Water Efficiency Team to provide the Center with water conservation and awareness ideas and water consumption and cost benchmarks. WFF provided. Energy Management Control System training to operations personnel at a cost of $\$ 13,000$. MSFC personnel attended the World Energy Engineering Congress in Atlanta sponsored by the Association of Energy Engineers. 
LaRC established the Outstanding Energy Achievement Award in FY 1993 for outstanding contributions to the implementation of energy conservation measures. The Award is presented at the Langley Awards Day observance, and the recipients are, in turn, nominated for the annual Federal Energy and Water Management Awards.

\section{Funding}

Projects and surveys are proposed by the energy manager at each Center and Component Facility, and the projects and surveys compete for funding along with other Center requirements. To compete successfully, projects having energy conservation as their sole purpose must have relatively short amortization periods since construction funds are very limited.

NASA-funded energy conservation projects are divided into two categories. The first consists of minor capital improvement projects (under $\$ 200,000$ ) that can be achieved with Center funds. The second consists of major capital improvement projects (over $\$ 200,000$ ) requiring Construction of Facilities $(\mathrm{CoF})$ program funding. Energy conservation projects must compete with all other construction projects for $\mathrm{CoF}$ funding.

NASA Procedures and Guidelines (NPG) 8820.2B, Facility Project Implementation Handbook, specifies procedures for submitting CoF projects. Life-cycle costing is the primary tool for analyzing energy retrofit projects.

Only one CoF project was implemented in FY 1997 for the sole purpose of energy or water conservation. This was the project undertaken at the Ames Research Center Administration Building. However, many $\mathrm{CoF}$ projects do contain features which will conserve energy or water and reduce costs. Examples include: HVAC system modernization, upgrade of energy monitoring and control systems, lighting and electrical system efficiency improvements, weatherization and other building envelope measures, and water conservation measures including conservation, recycling, and reuse projects.

It is not possible to accurately break out the cost of energy efficiency and water conservation measures from the overall budgeted amount for CoF discrete, repair, and rehabilitation and modification projects. The following estimate of FY 1997 and FY 1998 direct agency expenditures for energy efficiency and water conservation improvement projects and audits is based on data reported by the Centers and component facilities:
FY 1997

FY 1998

Direct Agency Expenditures $\$ 15,919 \mathrm{~K} \quad \$ 13,997 \mathrm{~K}$

\section{Energy Savings Performance Contracts}

NASA has limited experience with ESPC contracts. Although several Centers are actively pursuing ESPC projects, no ESPC contracts or delivery orders have been awarded, with the exception of the Energy Cost Reduction Program (ECRP) at Michoud Assembly Facility (MAF). MAF, a Government-owned, contractor-operated facility, implemented an ECRP with Lockeed-Martin Marietta Space Systems (LMMSS) in 1988. Under this program, LMMSS's prime contract with NASA was modified to include an energy conservation incentive clause. The program rewards LMMSS for exceptional performance in the management of energy usage at MAF by providing 8 to 14 percent of energy savings achieved as an additional award fee. The program also includes provisions for sharing savings achieved through energy conservation projects proposed by LMMSS. The share of savings is determined by whether NASA or LMMSS funds the capital investment. In FY 1995, the ECRP was modified to include cost savings for contractor recovery of utility company overcharges and negotiation of lower utility rates. Cumulative savings under the MAF ECRP program since FY 1988 total almost $\$ 15$ million, of which approximately 18 percent was awarded to LMMSS. Savings from the MAF ECRP were used to reduce the overall cost of the Space Shuttle External Tank program.

The following NASA Centers and Component Facilities are investigating ESPC contracts:

- Johnson Space Center (JSC) received contractor proposals for ESPC services through its base operations support services contract. The proposals identified cost-effective energy and water conservation measures requiring an investment of over \$20 million, with a corresponding annual cost savings of more than $\$ 2.5$ million. JSC is working with the National Renewable Energy Laboratory to contract for these services through the DOE Central Region Super ESPC.

- GSFC expects to award its first ESPC contract in the second quarter of FY 1998. This contract will install energy-efficient equipment in various GSFC buildings, including replacement of light fixtures, installation of motion sensors, and LED exit signs. 
- $\mathrm{KSC}$ is working with DOE to issue a delivery order under the Southeast Region Super ESPC contract. The project will include HVAC modifications and lighting retrofits in eight buildings totaling 2.3 million square feet.

- LeRC is working with DOE to participate in the Midwest Region Super ESPC. The project will include lighting retrofits, steam distribution system improvements, and chiller modifications for 20 buildings.

\section{Utility Partnerships}

NASA Centers received a total of $\$ 207,970$ in utility rebates during FY 1997. The rebates were received by the Kennedy Space Center $(\$ 201,070)$ and the Goddard Space Flight Center $(\$ 6,900)$. Stennis Space Center is in the third year of the standby generator program with the Mississippi Power Company. Utility cost credits in FY 1997 amounted to more than $\$ 47,000$.

\section{Energy Management Contact}

Mr. Richard A. Wickman

Environmental Management Division (JE)

National Aeronautics and Space Administration 300 E Street, SW

Washington, DC 20546-0001

Phone: 202-358-1113

Fax: 202-358-2861 


\section{NATIONAL ARCHIVES AND RECORDS ADMINISTRATION (NARA)}

\section{Energy Efficiency Performance and \\ Implementation Strategies}

The National Archives and Records Administration (NARA) owns and operates 12 separate facilities, dedicated to the preservation, storage, display, and use of historical documents and artifacts. Because the stringent records storage requirements are very energy intensive and preclude major changes in operational parameters to conserve energy, all of the NARA facilities are excluded from the energy reduction requirements of the National Energy Conservation Policy Act (NECPA).

During FY 1996, NARA initiated development of an agency energy plan in concert with the agency strategic planning process. The refinement and implementation of this plan continued in FY 1997.

Energy surveys of existing facilities are ongoing and are included in the design specifications for new facilities. Energy-efficient equipment, lights, and motors are specified in renovation work. An energy survey of the National Archives building, Washington, DC, and the National Archives at College Park, Maryland, identified several energy saving projects which are currently being implemented. Examples are:

- National Archives. Two chillers have been replaced with more efficient models and lights have been retrofitted.

- National Archives at College Park. Lights have been retrofitted and variable-frequency drives have been installed.

NARA's agency-wide policy is to incorporate energyefficient design into all new construction and renovation. An example of this effort is the recently completed NARA facility in Texas. Energy-efficient equipment is purchased whenever economical and feasible.

NARA operates an overall incentive award program which includes an award for exceptional performance in the energy conservation area.

\section{Funding}

NARA spent $\$ 618,470$ on facility energy efficiency improvements during FY 1997. Savings of 858.9 megawatt hours and $\$ 40,320$ per year are anticipated. NARA expects to spend $\$ 753,000$ in FY 1998.

\section{Energy Savings Performance Contracts}

NARA has entered into negotiations with a utility contractor for an energy savings performance contract.

\section{Utility Partnerships}

NARA has participated in rebate programs offered by the electrical utilities on energy-efficient lighting and variable-frequency drives. To date, $\$ 22,575$ in incentives have been received. Annual savings resulting from these projects are anticipated to be 736.9 megawatt hours and $\$ 15,120$.

\section{Energy Management Contact}

Mr. Patrick Alexander

Chief, Facilities Management Branch

NAFM Room 2320

National Archives and Records Administration

8601 Adelphi Road

College Park, MD 20740-6001

Phone: 301-713-6470, ext. 231 


\section{NUCLEAR REGULATORY COMMISSION (NRC)}

Energy Efficiency Performance and

Implementation Strategies

In FY 1997, the Nuclear Regulatory Commission's (NRC) One White Flint North (OWFN) building, Rockville, Maryland, reported a 1.5 percent increase in energy consumption as compared to FY 1989 , the first full year the building was occupied. The increase was attributed to a revision in NRC's FY 1997 building operation plan. During FY 1997, OWFN began a major renovation. As a result, air handler units were operated after normal working hours to ensure adequate filtration of dust and airborne particles.

NRC Buildings Energy Use and Costs, FY97

$\begin{array}{lrr} & \text { BBtu } & \text { S(Thou.) } \\ \text { Electricity } & 87.1 & 1,608.0 \\ \text { Natural Gas } & 1.0 & 8.3 \\ \text { Total } & 88.1 & 1,616.3\end{array}$

Energy consumption in NRC's Two White Flint North (TWFN) building reported a 6.1 percent increase in energy consumption as compared to FY 1995. The increase was attributed to HVAC design deficiencies, which allowed air to infiltrate the building at key employee and public access areas.

The NRC manages both facilities under a delegated authority agreement with the General Services Administration.

NRC's Energy Management Implementation Plan was developed in FY 1989 and is updated annually to identify strategies to meet the energy reduction goals of NECPA and Executive Order 12759. The energy management strategies implemented for both the OWFN Building and the TWFN Building in FY 1997 are:

- Use of automated energy management system to maximize energy efficiency of HVAC equipment;

- Use of interior lighting occupancy sensors;

- Implementation of an energy conservation employee awareness program;

- Utilization of HVAC free cooling using load curtailment program;

- Reduced chiller operations;
- Use of energy-efficient design technologies in construction and space renovation;

- Enhanced water treatment and filtering to enhance energy-efficient equipment operation;

- Installation of energy-efficient light bulbs and fixtures, including replacement of incandescent bulbs with compact fluorescent bulbs;

- Utilization of water management conservation technology; and

- Implementation of Commercial Facilities Management contract requirements to conserve energy by prudent equipment operating procedures and maintenance.

In addition, the HVAC system in the TWFN Building was retrofitted by the lessor in March 1997 to properly pressurize the building and balance the air distribution system.

\section{Training}

NRC is an active participant in the Interagency Energy Management Task Force, and staff members have attended seminars, workshops, and conferences sponsored by DOE and the Association of Energy Engineers.

\section{Energy Savings Performance Contracts}

NRC's Division of Facilities and Security is responsible for determining the feasibility and cost-effectiveness of energy savings performance contracts. As recommended by the DOE, the savings-to-investment ratio is used to calculate the projected energy and cost savings associated with the proposed project.

No energy savings performance contracts were awarded in FY 1997 for OWFN or TWFN. In FY 1998, NRC will examine the feasibility of awarding performance contracts to install occupancy sensors, LED exit signs, and electronic ballasts.

\section{Utility Partnerships}

During FY 1997, NRC's OWFN and TWFN buildings participated in the Potomac Electric Power Company's voluntary load curtailment program. Additionally, in FY 1998, a formal request will be made to PEPCO to conduct an energy audit of OWFN and TWFN to identify potential energy savings. 


\section{Vehicles}

NRC has an ongoing project to improve vehicle efficiency, including acquiring alternative fuel vehicles and downsizing the NRC vehicle fleet.

NRC has implemented several initiatives to reduce gasoline consumption, including:

- a video teleconferencing program which reduces the number of personnel traveling, and

- a transportation program which promotes the use of car and van pools and provides priority parking onsite to NRC employees who use them, provides a subsidy for employees who use public transit, provides bicycle racks and shower facilities for bicycle commuters, and includes participation in the Washington Metropolitan Council of Government's Guaranteed Ride Home Program (which provides free transportation home when an employee who commutes by car/van pool or public transit has an emergency.

These strategies have enabled NRC to reduce daily vehicle trips to the NRC headquarters site by 227 trips.

\section{Environmental Activities}

NRC installed a refrigerant purifier purge system on the chillers at OWFN to ensure compliance with the Clean Air Act of 1990. The equipment minimizes the level of ozone-depleting CFCs.

NRC has a strong program for recycling, waste reduction, and purchase of materials containing recovered materials. In FY 1997 NRC's accomplishments included:

- Recycled approximately 442,000 pounds of paper at its headquarters building;

- Recycled other materials, including newspapers, aluminum, glass, polystyrene, laser printer cartridges, and telephone directories;

- Consolidated various announcements and flyers into a single, effective weekly publication and equipped all photocopy machines with doublesided copying capacity; and

- Followed a formal purchasing policy that requires that products containing recovered materials be given preference over virgin material products.
Energy Management Contact

Mr. Edward Halman

Director, Office of Administration

Nuclear Regulatory Commission

Washington, DC 20555

Phone: $301-415-6222$

Fax: $301-492-5400$ 


\section{PANAMA CANAL COMMISSION (PCC)}

\section{Energy Efficiency Performance and \\ Implementation Strategies}

During FY 1997, the Panama Canal Commission reported a 25.2 percent increase in buildings energy consumption in Btu per gross square foot compared to FY 1985.

\section{PCC Performance Toward Buildings Energy Reduction Goals}

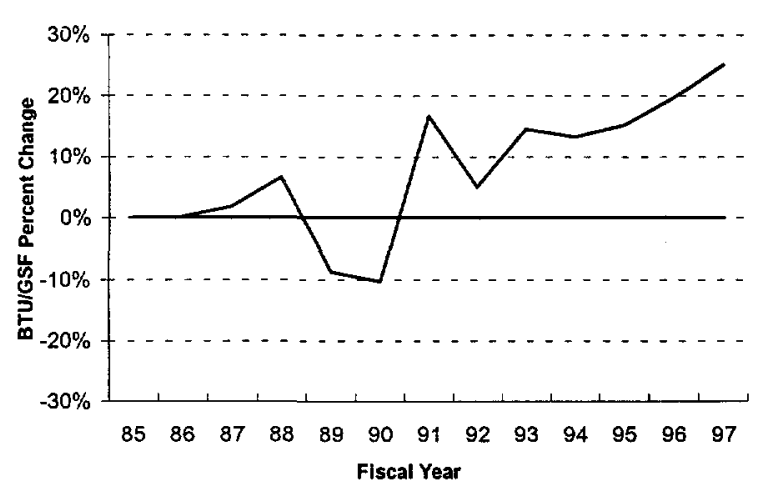

PCC Buildings Energy Use and Costs, FY97

$\begin{array}{rrr} & \text { BBtu } & \text { \$(Thou.) } \\ \text { Electricity } & 33.9 & 596.4 \\ \text { Total } & 33.9 & 596.4\end{array}$

The Commission, given its unique mission in the Republic of Panama, is not bound by targeted reductions of electrical power and associated energy for buildings/facilities, reductions of fuel use by vehicles, and procurements of alternative-fueled vehicles. Nevertheless, PCC will continue to manage the waterway consistent with these Federal efforts to the extent practical, until termination of the Commission and United States operation of the Panama Canal in December 1999 .

The Office of Executive Planning oversees agency-wide actions to implement energy plans and achieve projected goals through its Environmental/Energy Unit, and prepares guidance on procedures, policies, and other matters governing Federal energy management. Technical and engineering coordinators in energy consuming areas of the organization also provide needed assistance to maintain maximum operational energy efficiencies. To most effectively monitor consumption trends, reports on unit-level usage of electri- cal power, gasoline, diesel, and distillate fuel are submitted monthly to the environmental/energy staff.

PCC's Buildings Energy Plan was the basis for ongoing buildings maintenance, monitoring, and improvement programs. In FY 1997, the agency maintained a strong interest in technical advances that enhance energy efficiency. State-of-the-art energy savings measures were incorporated where practical in buildings and facilities under construction or renovation. Facilities with the highest consumption rates received first priority for energy-related lighting and air conditioning improvements.

Ongoing maintenance includes relamping and light fixture cleaning every three years or as needed. This program was established in conjunction with surveys performed to help determine specific requirements for reflectors, new ballasts, lenses, and changes from incandescent or mercury vapor to fluorescent or highpressure sodium/metal halide lights. Virtually all of the Commission's buildings have been retrofit with energyconserving lamps and light fixtures.

Additional energy conservation projects undertaken in FY 1997 include:

- Installation of programmable lighting controllers at two large industrial facilities, allowing for more efficient electricity usage during non-operating hours; and

- Installation of variable-speed drives on air handling units in three large office buildings, permitting more efficient use of electricity for cooling.

Annual energy savings from these projects are estimated at over $\$ 26,000$ annually.

\section{Training}

During FY 1997, one engineer received energy conservation training at a cost to the agency of $\$ 2,400$. In previous years, engineers have participated in energy conservation seminars, conferences, and the Department of Energy's TeleFEMP satellite video broadcasts.

\section{Funding}

The PCC functions on a self-financing basis, with recovery of all operating costs, including interest, depreciation, capital for plant replacement, expansion and improvements, and payments to the Republic of Panama for public services and annuities, through tolls and other revenues. Revenues from tolls and all other 
sources are deposited with the United States Treasury into the Panama Canal revolving fund. Resources in this account are available for continuous use, serve to finance Canal operating and capital programs, and are reviewed annually by Congress. PCC does not seek separate funding of its energy-related projects.

\section{Energy Savings Performance Contracts}

The Commission did not enter into energy savings performance contracts during the fiscal year. There is not sufficient economic opportunity for this type of initiative with PCC, given its self-financing basis, location overseas, and terminal status, in addition to the advanced service life of most of its buildings. Nevertheless, in FY 1997, PCC continued to implement a buildings/facilities retrofit program that has been responsive to the Federal effort for minimizing energy consumption and costs.

\section{Utility Partnerships}

The Commission maintains its own electrical power generation systems, including two hydropower plants that harness energy from Canal reservoirs. Thus, utility incentive programs are not available. PCC additionally distributes electrical power from its plants to other Canal area consumers, primarily U.S. military components that implement their own energy conservation programs in accordance with Federal guidelines and objectives.

\section{Mobility Fuel Usage/Vehicles}

Diesel fuel needed each year by dredges, drillboats, towboats, launches, and other floating gear dominates PCC energy consumption. Operation of this equipment is governed by cyclic maintenance and improvement schedules, ship traffic, and other requirements beyond agency control. Over the years PCC engineers have significantly improved fuel conservation of its dredges by replacing or converting old heavy fuel oil steampowered plants to diesel units and by intense renovation and modernization.

PCC's gasoline-operated vehicles have been replaced by diesel units where feasible. Agency policy further supports vehicle fuel savings by ensuring appropriate classes of vehicles for assignments, driver training, conservative driving practices, trip consolidation and similar measures. Gasoline and diesel/petroleum distillate fuel consumption in FY 1997 totaled 284,400 and 5,272,100 gallons respectively, at costs of $\$ 241,700$ and $\$ 3.4$ million.

\section{Energy Efficient Procurement}

Close procurement coordination with PCC operating units ensures that environmentally-friendly products are obtained for buildings retrofits, replacements, and other energy improvement initiatives. The Commission considers conservation and efficiency in acquisition decisions, and purchases recycled items when they meet criteria for availability, cost, and performance standards.

During FY 1997, PCC continued its program of replacing old computer monitors with models that consume less energy during idle time. All new computers purchases meet the EPA Energy Star specifications stipulated by Executive Order 12845.

\section{Environmental Activities}

PCC's active recycling projects include recovery of computer paper for offer in Panama at fair market value. Scrap iron, used oil, and surplus items also are collected for resale and recycling as part of conservation and waste minimization operations.

The U.S. Military in Panama publishes a weekly newspaper and operates an English-language television station accessible to Commission employees that actively promotes conservation and carries tips and information on energy use. PCC also furnishes agencywide directives and prints bilingual articles in its bimonthly official publication, The Spillway, to provide information on energy-related concerns.

\section{Energy Management Contact}

Mr. Juan H. Diaz

Environmental/Energy Control Officer

Office of Canal Improvements, Unit 2300

Panama Canal Commission

APO AA $34011-2300$

Phone: 202-634-6441

Fax: 202-634-6439 


\section{RAILROAD RETIREMENT BOARD (RRB)}

Energy Efficiency Performance and

Implementation Strategies

In FY 1997, the Railroad Retirement Board (RRB) reported a decrease of 2.2 percent in Btu per gross square foot compared to FY 1987, their first full year of reporting.

\section{RRB Buildings Energy Use and Costs, FY97}

$\begin{array}{lrr} & \text { BBtu } & \text { S(Thou.) } \\ \text { Electricity } & 22.4 & 536.3 \\ \text { Natural Gas } & 20.7 & 77.9 \\ \text { Total } & & \\ & 43.1 & 614.2\end{array}$

The headquarters building in Chicago, Illinois is the only building over which the Railroad Retirement Board has operational control. RRB operates and maintains the building under a delegation of authority agreement with the General Services Administration.

RRB updated its energy conservation plan in March 1993 to incorporate the requirements of NECPA, Executive Order 12759, and EPACT.

During FY 1997, the RRB invested in energy-efficient equipment and items such as T-8 fluorescent lamps, electronic ballasts, compact fluorescent bulbs, occupancy sensors, and air controllers. Additionally, building operation procedures have been refined to achieve the maximum energy savings.

The following projects and energy efficiency actions further reduced energy consumption in FY 1997:

- Installed automatic light sensors in public areas and conference rooms,

- Replaced incandescent bulbs with compact fluorescent lights in the Data Center and floor and desk lamps,

- Added caulk to inside of windows

- Reinsulated steam and chilled water pipes, and

- Significantly reduced agency man-hours worked on Saturdays, resulting in less energy usage.

\section{Training}

This agency does not meet the definition of an executive department under section 101 of Title 5, and therefore, is not subject to the energy management training provision of the Energy Policy Act. However, personnel responsible for energy management will receive the additional training that is to be provided by the General Services Administration under the EPACT requirements.

\section{Funding}

RRB utilizes building operation funding for energy conservation measures. Between $\$ 10,000$ and $\$ 20,000$ per year of building operating funds are available for such measures. GSA, as the Government owner of the RRB building, has the responsibility to fund projects over $\$ 50,000$ and has future projects planned, but not funded.

\section{Energy Savings Performance Contracts}

RRB has not entered into any ESPC contracts. The comparatively small size of potential contracts available to RRB - at a \$50,000 limit because of the delegation of authority agreement with GSA - is not practical for this type of procurement.

\section{Utility Partnerships}

No opportunities exist for utility demand-side services, incentives, or rebates, but RRB will continue to monitor its utilities for opportunities that may develop.

\section{Vehicles}

RRB owns no vehicles. However, RRB is developing information to be provided to their employees concerning ridesharing awareness and fuel usage reduction measures.

\section{Environmental Activities}

All obsolete fluorescent ballasts have been and will continue to be disposed of safely. Older CFC drinking fountains are being replaced with new, energy-efficient, non-CFC refrigerant fountains.

RRB has developed procedures to ensure procurement of energy-efficient products whenever cost effective.

\author{
Energy Management Contact \\ Mr. Henry M. Valiulis \\ Director of Supply and Service \\ U.S. Railroad Retirement Board \\ Room 1230 \\ 844 North Rush Street \\ Chicago, IL 60611 \\ Phone: 312-751-4565 \\ Fax: 312-751-4923
}




\section{SOCIAL SECURITY ADMINISTRATION (SSA)}

Energy Efficiency Performance and Implementation Strategies

SSA's strategy for meeting the goals of EPACT and Executive Order 12902 includes a combination of energy audits and energy conservation projects. For each of its delegated buildings, SSA has developed a Building Action Plan that identifies possible energyand cost-saving projects.

\section{SSA Buildings Energy Use and Costs, FY97}

$\begin{array}{lrr} & \text { BBtu } & \text { \$(Thou.) } \\ \text { Electricity } & 642.8 & 9,641.4 \\ \text { Fuel Oil } & 11.8 & 66.9 \\ \text { Natural Gas } & 131.1 & 728.4 \\ \text { Purchased Steam } & 28.2 & 377.4 \\ & & \\ \text { Total } & 814.0 & 10,814.1\end{array}$

SSA has planned more than $\$ 67$ million of building renovations between FY 1996 and FY 2000. While not exclusively energy projects, these renovations will include energy-efficient central heating and air conditioning plants, energy-efficient windows and doors, new central energy management systems, and lighting controls.

SSA has analyzed a variety of solar and renewable energy technologies for its headquarters buildings. Natural day lighting has been a viable technology, but so far neither solar water heating nor solar lighting have been proven economically viable.

Seven SSA facilities, comprising nearly half of SSA's square footage, have had comprehensive energy audits. These audits have identified projects that meet energy and water conservation project requirements. Savings and job cost estimates have been completed to ascertain a savings-to-investment ratio and life-cycle cost for each project in the audit.

The National Computer Center (NCC), SSA's most energy-intensive facility, underwent a comprehensive energy audit and a central chiller plant optimization study in FY 1997. The NCC has the highest energy consumption of any SSA facility because of the intensive computer operations to support SSA's automated systems. These efforts identified $\$ 700,000$ in energy conservation projects. Also, a new central heating/ cooling plant is being installed as a result of the study. The new plant should provide $\$ 73,000$ in annual demand savings and the energy projects should save
$\$ 271,000$, or 4.6 megawatt hours, per year. Construction began in June 1997 and will continue for one year.

Other energy savings projects completed or initiated during FY 1997 included:

- Installation of an energy management system at the Operations Building which will enable the lighting system to be programmed, resulting in savings of $\$ 250,000$ per year in lighting costs.

- Installation of low-flush toilets and low-flow faucets in the West High Rise Building, reducing water consumption by 60 percent.

- The retrofit of the Supply Building warehouse lights, along with the installation of a computer controlled lighting system.

- The initiation of a project at the Western Program Service Center in San Francisco, California that will use water from an underground stream for irrigation, flushing toilets, and to provide make up water for the cooling tower.

- Installation of low-flush toilets and aerators at the Mid-Atlantic Program Service Center in Philadelphia, Pennsylvania.

- Installation of revolving doors and improving building insulation at the Northeast Program Service Center in Jamaica, New York.

- The renovation of the East High and Low Rise buildings continued. Upon completion, the HVAC and electrical systems will have been upgraded, exterior walls and windows will have been replaced, variable-speed pumps will have been installed, and the lighting will have been retrofitted.

SSA has prospective projects planned through 2006. Through these projects, many of SSA's older buildings will receive new central plants, upgraded exteriors, energy-efficient lighting, and demand side management technologies.

\section{Training}

Building managers and staff have attended a variety of training classes and conferences on several subjects, including life-cycle cost analysis, alternative fuels, lighting, controls, and demand side management practices. SSA staff attend GSA regional conferences to 
stay familiar with current strategies in GSA's program to reduce energy consumption. SSA is developing a training plan for SSA employees to become trained energy managers. This plan is to be implemented in FY 1998. SSA has technical and contracting staff trained in energy savings performance contracts.

While SSA has not established an incentive program for employees implementing EPACT and Executive Order 12902, SSA does award employees whose job descriptions require energy management skills and whose overall performance or individual acts are exceptional.

\section{Funding}

SSA has aggressively pursued GSA funding to install energy-efficient systems and equipment. SSA received $\$ 700,000$ from GSA's energy efficiency fund for the lighting retrofit and energy-efficient motor installation at the NCC.

GSA's energy conservation funds for delegated agencies has been the primary source of SSA funding. However, SSA has included funding specifically for energy conservation measures in its annual budget for FY 1998. SSA is using both agency and delegation funds to accomplish energy conservation projects that do not meet GSA's funding criteria.

\section{Energy Savings Performance Contracts}

SSA has not initiated any energy savings performance contracts to date. Many of the ideal candidate projects (primarily lighting) have either been accomplished or will be through GSA prospectus work. To date, direct funding has been used for energy efficiency projects.

However, smaller projects may be feasible through energy savings performance contracts. These include remaining lighting retrofits and installation of energyefficient motors. SSA is exploring the use of DOE's Regional Super ESPC being developed for the MidAtlantic and Northeast regions. SSA has several potential projects that may be accomplished through this vehicle.

\section{Utility Partnerships}

GSA has several area wide utility contracts which include SSA headquarters buildings in Baltimore and the Northeast Program Services Center. SSA is designated as an ordering official on these projects and has used them to perform energy audits and energy conservation projects.

\section{Environmental Activities}

In FY 1997, three plants (the Great Lakes Program Service Center in Chicago, the Western Program Services Center, and the Mid-Atlantic Program Services Center) were converted to CFC-compliant equipment. In 1997, a contract was awarded to replace chillers in the NCC. At the conclusion of this contract, eight out of 13 central plants will be CFC-compliant. One of the three remaining non-CFC plants should be converted in FY 2000.

It is SSA practice to recycle both lamps and ballasts. This requirement has been incorporated into SSA contracts. All existing motors which have been replaced with energy-efficient motors have been recycled.

\author{
Energy Management Contact \\ Mr. Ed Harmon \\ Office of Realty Management \\ Social Security Administration \\ 1-B-25 Operations Building \\ 6401 Security Boulevard \\ Baltimore, MD 21235 \\ Phone: 410-965-4989 \\ Fax: 410-966-0668
}




\section{TENNESSEE VALLEY AUTHORITY (TVA)}

\section{Energy Efficiency Performance and} Implementation Strategies

During FY 1997, the Tennessee Valley Authority reported a 17.2 percent decrease in energy consumption in Btu per gross square foot compared to FY 1985.

TVA Performance Toward Buildings Energy Reduction Goals

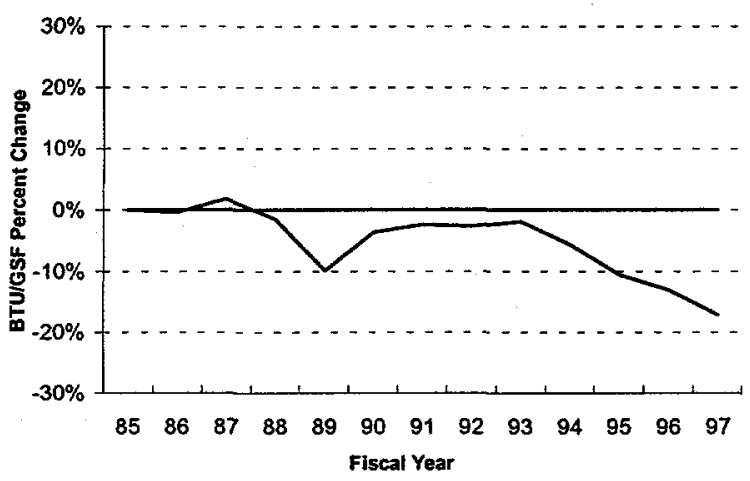

TVA Buildings Energy Use and Costs, FY97

$\begin{array}{lrr} & \text { BBtu } & \text { \$(Thou.) } \\ \text { Electricity } & 660.3 & 8,515.5 \\ \text { Natural Gas } & 5.3 & 51.3 \\ \text { Total } & 665.6 & \mathbf{8 , 5 6 6 . 9}\end{array}$

TVA's Energy Plan ensures the efficient use of energy in the operation, maintenance, and design of TVA buildings and facilities. During FY 1997, TVA implemented energy conservation opportunities (ECOs) costing $\$ 1.16$ million, with potential annual savings of more than $\$ 600,000$. This is an average payback of 1.9 years.

To meet the challenge of surveying more buildings, the DOE Facility Energy Decision System(FEDS) building energy analysis program is being used to identify and evaluate potential ECOs. Cost-effective ECOs are identified through the FEDS software, allowing manpower to be used more effectively and efficiently for implementation of measures.

The following are sample retrofits performed on buildings during FY 1997:

- A pilot program designed to upgrade lighting systems at remote buildings was started in FY 1997;
- Large water tanks in the Chattanooga Office Complex were retrofitted to accept chilled water in the summer and hot water during the winter. These are now used to supplement building heating and cooling requirements;

- A new energy-efficient chiller was installed in Monteagle Place;

- A new chiller, cooling tower, heat pumps, circulating pumps and piping at the Chickamauga Power Service Center were installed;

- Water reduction project put in place at Muscle Shoals; and

- Energy management and control systems (EMCS) were installed in eight facilities. TVA now has EMCS installed in 20 buildings.

During FY 1997, TVA also completed 73 fossil energy reduction projects at 11 different sites, 16 hydro energy reduction and modernization projects at 10 different sites, and nine nuclear energy reduction projects at three different sites.

\section{Training}

TVA provides training for employees in order to accomplish objectives for the Internal Energy Management Program (IEMP). TVA provides updates on current Federal requirements and regulations for employees, managers, and TVA customers when requested. Ongoing energy management training is provided to managers of facilities. Building energy monitors are appointed and trained for all primary corporate buildings. TVA also educates staff in both energy- and environmental-related topics through the TVA University.

\section{Funding}

TVA is establishing funding procedures for energy management projects under the IEMP and through the Agency Energy Management Committee. Buildings projects are primarily funded through renovation and modernization efforts. General operations projects are ranked for economic benefit compared to other TVA projects to determine funding availability and implementation status and are funded mainly through the capital budgeting process.

\section{Energy Savings Performance Contracts}

TVA considers the use of energy savings performance contracts when cost effective for TVA and its custom- 
ers. During 1997, TVA did not enter into any energy savings performance contracts.

\section{Utility Partnerships}

TVA supports energy-saving demand-side activities when cost effective and in the best interest of its customers. TVA is currently investigating the potential for partnerships with its customers for development of demand-side programs and activities. Strategies recommended in TVA's Integrated Resource Plan (IRP) would increase TVA's activity in the implementation of demand-side management programs.

\section{Vehicles}

In FY 1997, TVA operated its sedan fleet using a combination of primarily 1995 Chevrolet Corsicas and 1996 Dodge Stratas. During FY 1997, TVA eliminated the sedan motor pool fleet and initiated efforts to reduce the size of the work vehicle fleet. At the close of FY 1997, the sedan fleet consisted of 168 compact, 39 mid-size, and 74 full-size sedans.

In FY 1997, TVA did not purchase any additional alternative fuel vehicles (AFVs) and the AFV fleet consisted of 21 M-85 flexible fuel vehicles (FFV), two compressed natural gas (CNG) dedicated vans, and 15 electric vehicles (EVs).

TVA discontinued the use of the M-85 FFVs and the CNG dedicated vans in FY 1996. These vehicles are now targeted for sale and disposal.

As a major supplier of electricity, TVA is particularly interested in supporting the use of EVs. TVA continues to incorporate EVs into its fleet operations, and continues to support power distributors and local communities with $\mathrm{EV}$ technology demonstrations

\section{Environmental Activities}

In keeping with its goal of environmental responsibility, TVA became the first Federal agency to join the EPA/DOE Green Lights Program and is in the process of becoming a partner in the EPA/DOE Energy Star Building program. TVA is also involved in solid waste minimization, sustainable architecture, by-products with recycle content, reduction of greenhouse gas programs, and other applications of environmental stewardship in conduct of its business.

TVA has developed a pilot program named SWAP as part of its commitment under the Green Lights program. SWAP was developed to eliminate the cycle time for lighting upgrades and to reduce survey and design costs as part of these efforts. The agency-wide net present value of SWAP is over $\$ 1$ billion. In FY 1998, a pilot program, SWAP II, will be initiated to evaluate the implementation of lighting controls as a first step in the reduction of energy.

TVA continues the "Waste Free" program in its corporate buildings. The reductions were achieved by replacing paper towels with hand dryers; employing reusable beverage mugs in place of styrofoam and paper cups; and recycling white and mixed paper, cardboard, newspaper, plastic, glass, and steel and aluminum cans. Employees have multi-compartmented recycle boxes in place of their trash cans to separate items at their desks. In addition to typical office waste, TVA continues to recycle used batteries, fluorescent light tubes, and PCB ballasts. Many light tubes which are still usable after group relampings are donated to local schools, then collected for recycling by TVA after they burn out.

TVA's Sustainable Architecture Program was established to promote and support efforts to use sustainable building materials in TVA. Sustainable materials use recycled content, are nontoxic, are produced locally, use minimum amounts of natural resources in the manufacturing process, and can be reused or recycled at the end of its life.

TVA was awarded a Closing the Circle award in May 1997 for its Sustainable Architecture Program. This award is given in celebration of environmental excellence in Government. TVA's renewable home design won the Government Design of Choice. It incorporated solar and renewable design, sustainable materials, and overall energy efficiency.

TVA undertook 34 water management activities during FY 1997 to help reduce energy consumption and environmental impact.

\author{
Energy Management Contact \\ Mr. Stephen L. Brothers, Jr. \\ Power Utilization Engineer \\ Internal Energy Management Program \\ Tennessee Valley Authority \\ Facilities and Realty Management \\ 1101 Market Street \\ Chattanooga, TN 37402-2801 \\ Phone: 423-751-7369 \\ Fax: 423-751-6309
}




\section{UNITED STATES POSTAL SERVICE (USPS)}

\section{Energy Efficiency Performance and}

Implementation Strategies

In FY 1997, energy use in U.S. Postal Service facilities decreased by 12.1 percent in Btu per gross square foot compared to FY 1985.

\section{USPS Performance Toward Buildings Energy Reduction Goals}

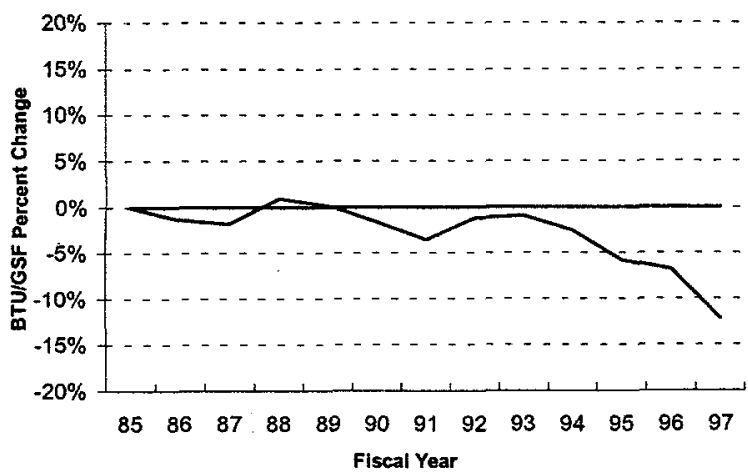

USPS Buildings Energy Use and Costs, FY97

$\begin{array}{lrr} & \text { BBtu } & \text { \$(Thou.) } \\ \text { Electricity } & 13,218.6 & 292,111.8 \\ \text { Fuel Oil } & 819.0 & 5,727.6 \\ \text { Natural Gas } & 7,428.8 & 41,863.4 \\ \text { Other } & 540.0 & 5,486.4 \\ & & \\ \text { Total } & 22,006.4 & 345,189.2\end{array}$

Since 1985, the Postal Service has deployed energy intensive automation equipment which has improved the efficiency of mail operations. Surveys indicate that the automation and mechanization deployment has caused a calculated increase in the process energy usage of 8 percent in FY 1997. This increase is offsetting the energy efficiency gains made in Postal facilities.

To provide a better measure of the energy-efficient status of Postal Service facilities, the USPS has factored out the process energy consumed by mail processing equipment from energy efficiency calculations for USPS facilities.

If the process energy used by the automated equipment were not factored out, energy consumption in USPS facilities would have shown a decrease in Btu per gross square foot of only 4.3 percent in FY 1997 compared to FY 1985
The United States Post Office Engineering group has overall responsibility for the Postal Service energy program. The Environmental Management Program (EMP) located at USPS headquarters is the focal point for the coordination, development, and execution of corporate energy management plans. EMP coordinates and solicits participation from representatives from USPS Facilities, Transportation, Procurement, Finance, and Engineering divisions to annually review existing energy plans and develop new strategies to assure compliance with the Energy Policy Act of 1992.

In each of the 10 area offices, area environmental compliance coordinators (AECCs) are responsible for program administration of energy conservation within their geographical areas and receive technical assistance from the maintenance support units. AECCs are responsible for the development of area wide energy conservation plans and execution of energy projects.

At processing and distribution facilities, the maintenance manager typically is appointed as facility energy coordinator (FEC) and is in charge of the day-to-day conservation efforts. FECs report energy consumption, monitor performance, and identify energy retrofit projects. The postmaster or station manager is responsible for energy conservation at the customer service level. The District Environmental Compliance $\mathrm{Co}$ ordinator (DECC) and manager of field maintenance operations provide program administration and technical support to FECs and postmasters. DECCs monitor and report energy performance for their districts, identify energy retrofits and provide planning assistance to their AECCs in developing the area energy plan.

The Postal Service's strategy to attain the energy consumption reduction goals are:

- capital investment of energy-efficient equipment;

- affirmative purchasing of energy conservation products and services;

- education and awareness of employees;

- continued execution of energy savings performance contracts;

- participation in utility demand side management programs;

- design and construction of energy-efficient buildings; 
- improved operation and maintenance procedures;

- capital investments for energy retrofit projects;

- procurement of energy-efficient products; and

- installation of automatic controls.

The Postal Service plans to focus its audit priorities on processing and distribution facilities and customer service facilities over 5,000 square feet in size. In FY 1997 , over 3,000 building surveys were conducted to establish priorities for energy conservation projects. Additional comprehensive and detailed energy audits were performed at larger facilities which will identify further energy savings opportunities. The results of these studies allowed the Postal Service to invest $\$ 16$ million in FY 1997 on projects with a return on investment of 20 percent or higher.

During FY 1997, the Postal Service developed the USPS Green Building Design Guide, which provides design standards for energy-efficient systems. The Guide also includes initiatives which incorporate environmental consideration in the design and construction of new facilities.

In FY 1997, the Postal Service purchased and installed over 30,000 LED exit signs. The total cost was approximately $\$ 750,000$, generating an estimated savings of $\$ 2$ million per year, taking into consideration savings to purchasing, maintenance operations, and actual energy savings.

The Postal Service is working with Granger Inc. to develop a catalog of energy-efficient products and supplies for use by facility managers. Granger also agreed to perform motor surveys and provide replacement motor recommendations with a high energy efficiency rating.

Application of renewable energy as an alternative fuel source is investigated as a part of the energy surveys. The evaluation of renewable energy for securing duelfuel capability is encouraged during the design process of new postal facilities. In FY 1997, several postal facilities installed solar lighting, including facilities in Hawaii, South Carolina, and southern California.

Also during FY 1997, the USPS Baltimore District installed 12 geothermal pump HVAC systems in Maryland post offices. As a direct result, 40 underground storage tanks are to be eliminated. The capacity of the geothermal pumps range from 5 to 15 tons for buildings ranging in size from 5,000 to 18,000 square feet. In FY 1998, a 100-ton unit is being designed for installation at a USPS facility in Maryland.

\section{Energy Showcase Facilities}

The Postal Service has designated three buildings as energy showcases. These facilities are located in Portland, Oregon; St. Paul, Minnesota; and Fort Lauderdale, Florida. Energy audits have been completed at the three facilities and various retrofit projects are scheduled for completion. These projects include installing T-8 lights with electronic ballasts, upgrading central HVAC systems, and installing better energy management controls.

The Postal Service is working with DOE, local utility companies, and other contractors to make these facilities examples of energy conservation and efficiency efforts.

\section{Training}

In FY 1997, the Postal Service developed a series of training seminars on energy savings performance contracts, energy program management, and utilities procurement strategy. These training classes were attended by appointed energy managers and procurement officials responsible for buying utilities and awarding energy retrofit projects. The Postal Service will continue to provide additional training in energy as the need is identified.

A quarterly newspaper for purchasing personnel covers specific energy and environmental issues. Training materials have been developed to emphasize the role and responsibility of contracting officers in complying with energy and environmental regulations. Development of energy-specific guidance for inclusion in the Postal Service Procurement Manual is ongoing. Also, the Postal Service has signed a memorandum of understanding with the EPA to participate in the Energy Star program.

Energy awareness programs include several articles presented on energy-efficient initiatives on the USPS electronic postal link system, Web page, Postal Bulletin, newspapers, etc. Facility and individual energy efficiency awards were presented to USPS employees in early FY 1998.

The Postal Service participated in the "You have the Power" energy campaign, and more than 10,000 posters were distributed throughout 36,000 postal facilities. Six Postal Service energy champions were identified and featured in these posters. 


\section{Funding}

Energy projects within the Postal Service are prioritized using criteria such as operational needs, safety and health issues, and environmental benefits, in addition to energy savings. Economic benefits are measured by net present value and return on investment to the Postal Service. Funds for implementation of energy retrofit projects may be provided by the local and area office budgets or by headquarters.

In 1997 , the Postal Service centrally funded $\$ 16$ million for the purpose of improving the energy efficiency of its facilities. Headquarters and Area funds for energy retrofits are made available for projects which are prioritized based on return on investment. Projects are ranked primarily based on this and are funded until budgeted funds are depleted.

The Postal Service's "best value" buying philosophy fits well with the procurement of energy-efficient goods and products. Factors other than price, such as energy consumption, energy efficiency, and other life cycle costing factors relating to energy conservation should carry as much or more weight in determining contract awards.

\section{Energy Savings Performance Contracts}

The Postal Service began overseeing shared energy savings (SES) contracts, the agency equivalent to energy savings performance contracts, in 1987. The Postal Service now has 22 SES contracts in place covering 926 facilities. The total investment cost so far is $\$ 20.8$ million, and the expected total energy savings is $\$ 3.43$ million per year.

In FY 1997, the Postal Service implemented seven additional SES projects covering 417 facilities in Royal Oak, Michigan; Detroit, Michigan; Alexandria, Virginia; Washington, DC; Jamaica, New York; Atlanta, Georgia; and Hawaii. The total investment was $\$ 2.84$ million, and the annual savings will be $\$ 523,000$.

\section{Energy Management Contact}

Mr. Bernie Denno

Environmental Programs Analyst

Environment Management Policy

United States Postal Service

Room 6830

475 L'Enfant Plaza, SW

Washington, DC 20260-2810

Phone: 202-268-6014

Fax: 202-268-6016 
This Page Intentionally Left Blank 


\section{APPENDIX A \\ LIST OF AUTHORITIES}

ENERGY POLICY AND CONSERVATION ACT (Public Law 94-163), December 1975

SECTION 381 - FEDERAL ENERGY CONSERVATION PROGRAMS

DEPARTMENT OF ENERGY ORGANIZATION ACT (Public Law 95-91), August 1977 TITLE III - TRANSFERS OF FUNCTIONS

NATIONAL ENERGY CONSERVATION POLICY ACT (Public Law 95-619), November 1978

FEDERAL ENERGY MANAGEMENT IMPROVEMENT ACT OF 1988 (Public Law 100615), November 1988

ENERGY POLICY ACT (Public Law 102-486), October 1992

EXECUTIVE ORDER 12759, April 17, 1991

FEDERAL ENERGY MANAGEMENT

EXECUTIVE ORDER 12902, March 6, 1994

ENERGY EFFICIENCY AND WATER CONSERVATION AT FEDERAL FACILITIES

OFPP POLICY LETTER NO. 76-1, August 6, 1976

FEDERAL PROCUREMENT POLICY CONCERNING ENERGY POLICY AND

CONSERVATION

SUPPLEMENT NO. 1 TO OFPP POLICY LETTER 76-1, July 2, 1980

\section{OTHER FEDERAL REGULATIONS}

FEDERAL ACQUISITION REGULATION

48 C.F.R. $\S \S 23.201-203$ (1995)

FEDERAL ENERGY MANAGEMENT AND PLANNING PROGRAMS

10 C.F.R., Part 436 (1996)

FEDERAL PROPERTY MANAGEMENT REGULATION

41 C.F.R., Part 101-25 (1996) 


\section{APPENDIX B \\ DATA COLLECTION}

Buildings and Facilities

Excluded Buildings/Process Operations

The Federal agencies that own or control buildings are required to report the energy consumption in these buildings to FEMP 45 days after the end of each fiscal year. The General Services Administration (GSA) reports the energy of buildings it owns and operates, including usage by other Federal agency occupants. For buildings which have been delegated by GSA to other agencies, the individual agencies are responsible for reporting the energy consumption and square footage figures.

The data shown in this report do not include leased space in buildings where the energy costs are a part of the rent and the Federal agency involved has no control over the building's energy management.

The Federal agencies submit their annual reports expressed in the following units: megawatt hours of electricity; thousands of gallons of fuel oil; thousands of cubic feet of natural gas; thousands of gallons of liquefied petroleum gas (LPG) and propane; short tons of coal; billions of Btu of purchased steam; and billions of Btu of "other." DOE reviews this data for accuracy and confers with the submitting agency to clarify any apparent anomalies. The data are then entered into a computer database management program.

The tables shown in this Annual Report are expressed in billions of Btu derived from the following conversion factors:

$\begin{array}{lll}\text { Electricity } & - & 3,412 \mathrm{Btu} / \text { kilowatt hour } \\ \text { Fuel Oil } & - & 138,700 \mathrm{Btu} / \text { gallon } \\ \text { Natural Gas } & - & 1,031 \mathrm{Btu} / \text { cubic foot } \\ \text { LPG/Propane } & - & 95,500 \mathrm{Btu} / \text { gallon } \\ \text { Coal } & - & 24,580,000 \mathrm{Btu} / \text { short ton } \\ \text { Purchased Steam } & - & 1,000 \mathrm{Btu} / \text { pound }\end{array}$

In addition, the Federal agencies annually report to FEMP the gross square footage of their buildings and the cost of their buildings' energy.

This report excludes those agencies that have been unable to provide complete fiscal year consumption data prior to the publication date. All agency omissions, as well as any anomalies in the data, are indicated by footnotes on the tables or in the text of the report. 


\section{Vehicles and Equipment}

Federal agencies are required to report the energy consumption of their vehicles and equipment to FEMP within 45 days after the end of each fiscal year.

The fuels used in vehicles and equipment are automotive gasoline, diesel and petroleum distillate fuels, aviation gasoline, jet fuel, navy special, liquefied petroleum gas/propane, and "other." All the fuels in this category with the exception of "other" are reported in thousands of gallons.

"Other" is reported in billions of Btu.

The conversion factors for these fuels are:
Automotive Gasoline - $125,000 \mathrm{Btu} /$ gallon
Diesel-Distillate $\quad-138,700 \mathrm{Btu} /$ gallon
Aviation Gasoline - $\quad 125,000 \mathrm{Btu} /$ gallon
Jet Fuel
- $130,000 \mathrm{Btu} /$ gallon
Navy Special
- 138,700 Btu/gallon
LPG/Propane
- 95,500 Btu/gallon

Missing data and anomalies are addressed in the same fashion as those described previously in this appendix. 


\section{Calculation of Estimated Carbon Emissions}

Carbon emissions were calculated by multiplying energy consumption for each fuel type by an associated carbon coefficient shown below. These coefficients are derived from DOE/EIA-0573, Emissions of Greenhouse Gases in the United States, 1987 - 1992, November 1994; Tables 5, $\mathrm{A} 1, \mathrm{~A} 3$, and $\mathrm{A} 4$.

Carbon coefficients are calculated by dividing the carbon content of a particular fuel (for example, 0.85 metric tons of carbon per ton of fuel) by the energy content of that fuel (say, 43 million Btu per metric ton), producing an emissions coefficient (in this example, 19.8 million metric tons of carbon per quadrillion Btu (quad), which is the same as 19.8 metric tons per billion Btu). The different coefficients result from differences in the amount of carbon released when the various fossil fuels are burned. The amount of carbon released depends, in turn, on the density, carbon content, and gross heat combustion of the fuel in question.

The coefficients used in this report are as follows:

Energy Type

Electricity

Fuel Oil

Natural Gas

LPG/Propane

Coal

Purchased Steam

Auto Gas

Diesel

Aviation Gas

Jet Fuel

Navy Special

\section{Metric Tons/Billion Btu}

(Site-Delivered)

50.16

19.95

14.47

17.16

25.69

35.71

19.41

19.95

18.87

19.74

21.49

The electricity coefficient is based on 1992 carbon emissions from electric utilities per 1992 sitedelivered electricity consumption. (Table 5, DOE/EIA-0573 and Table 8.1, DOE/EIA-0384(93), Annual Energy Review 1993.) This coefficient of 50.16 metric tons per billion Btu (or million metric tons per quad) is applied to site-delivered Btu consumption of electricity. It is equivalent to a coefficient of 14.75 metric tons per billion Btu used for primary Btu consumption of electricity and reflects a generation mix of electricity consumption of approximately 55 percent coal, 10 percent natural gas, 3 percent fuel oil, 22 percent nuclear, and 9 percent hydro/ renewables.

The purchased steam coefficient applies the coefficient for coal to the primary energy Btu (converted from site-delivered Btu by using a factor of 1.39). 


\section{APPENDIX C}

FEDERAL ENERGY EXPENDITURES,

FY 1985 THROUGH FY 1997 
TABLE C

FEDERAL ENERGY EXPENDITURES, FY 1985 THROUGH FY 1997 (CONSTANT 1997 DOLLARS)

\begin{tabular}{|c|c|c|c|c|}
\hline Year & $\begin{array}{c}\text { Annual } \\
\text { Energy Use } \\
\text { (BBTU) }\end{array}$ & $\begin{array}{l}\text { Annual } \\
\text { Energy Cost } \\
\text { (\$ MILLION) }\end{array}$ & $\begin{array}{l}\text { Annual } \\
\text { Energy Cost } \\
\text { (\$MMBTU) }\end{array}$ & $\begin{array}{l}\text { Change in Energy } \\
\text { Costs from } 1985 \\
\text { (\$ MILLION) }\end{array}$ \\
\hline \multicolumn{5}{|c|}{ Buildings \& Facilities } \\
\hline 1985 & $471,621.4$ & $5,723.085$ & 12.135 & 0.000 \\
\hline 1986 & $447,005.0$ & $5,170.697$ & 11.568 & -552.387 \\
\hline 1987 & $468,659.3$ & $5,172.321$ & 11.037 & -550.764 \\
\hline 1988 & $443,721,5$ & $4,697.505$ & 10.586 & $-1,025.579$ \\
\hline 1989 & $440,577.1$ & $4,291,122$ & 9.739 & $-1,431.963$ \\
\hline 1990 & $441,134.1$ & $4,771.078$ & 10.815 & -952.006 \\
\hline 1991 & $404,193.8$ & $4,331.128$ & 10.716 & $-1,391.956$ \\
\hline 1992 & $413,142.0$ & $4,111.071$ & 9.951 & $-1,612.014$ \\
\hline 1993 & $403,110.9$ & $4,285.832$ & 10.632 & $-1,437,252$ \\
\hline 1994 & $385,668.4$ & $4,057.369$ & 10.520 & $-1,665.715$ \\
\hline 1995 & $366,493.2$ & $3,793.069$ & 10.349 & $-1,930.016$ \\
\hline 1996 & $358,455.2$ & $3,705.707$ & 10.338 & $-2,017.377$ \\
\hline 1997 & $350,329.7$ & $3,559.962$ & 10.162 & $-2,163.123$ \\
\hline \multicolumn{5}{|c|}{ Vehicles \& Equipment } \\
\hline 1985 & $934,333.0$ & $8,687.862$ & 9.298 & 0.000 \\
\hline 1986 & $924,833.7$ & $5,240.022$ & 5.665 & $-3,447.840$ \\
\hline 1987 & $958,904.3$ & $5,546.240$ & 5.783 & $-3,141.623$ \\
\hline 1988 & $846,896.1$ & $5,245.953$ & 6.195 & $-3,441.909$ \\
\hline 1989 & $959,994.5$ & $5,875.294$ & 6.120 & $-2,812.568$ \\
\hline 1990 & $926,994.8$ & $6,325.125$ & 6.824 & $-2,362.738$ \\
\hline 1991 & $970,454.3$ & $7,789.163$ & 8.027 & -898.700 \\
\hline 1992 & $783,122.4$ & $4,618.530$ & 5.898 & $-4,069.332$ \\
\hline 1993 & $772,633.7$ & $4,852.848$ & 6.280 & $-3,835.015$ \\
\hline 1994 & $722,790.8$ & $3,452.663$ & 4.777 & $-5,235.199$ \\
\hline 1995 & $687,143.4$ & $3,574.554$ & 5.202 & $-5,113.309$ \\
\hline 1996 & $675,111.3$ & $3,499.797$ & 5.184 & $-5,188.066$ \\
\hline 1997 & $665,385.6$ & $4,032.599$ & 6.061 & $-4,655.263$ \\
\hline \multicolumn{5}{|c|}{ Energy Intensive Operations } \\
\hline 1985 & $39,723.2$ & 584.265 & 14.708 & 0.000 \\
\hline 1986 & $38,285.3$ & 539.057 & 14.079 & -45.208 \\
\hline 1987 & $38,631.6$ & 530.119 & 13.723 & -54.146 \\
\hline 1988 & $69,668.3$ & 871.338 & 12.507 & 287.073 \\
\hline 1989 & $63,873.1$ & 706.475 & 11.060 & 122.210 \\
\hline 1990 & $65,262.1$ & 792.550 & 12.144 & 208.285 \\
\hline 1991 & $83,681.1$ & 918.341 & 10.975 & 334.076 \\
\hline 1992 & $97,993.2$ & $1,001.449$ & 10.219 & 417.184 \\
\hline 1993 & $70,838.9$ & 662.386 & 9.350 & 78.120 \\
\hline 1994 & $70,686.0$ & 681.691 & 9.644 & 97.426 \\
\hline 1995 & $75,822.8$ & 615.318 & 8.115 & 31.053 \\
\hline 1996 & $74,124.4$ & 648.726 & 8.752 & 64.460 \\
\hline 1997 & $66,501.2$ & 662.227 & 9.958 & 77.962 \\
\hline
\end{tabular}

${ }^{1}$ Changes in energy costs from 1985 should not be construed as savings resulting from Federal energy management activities. Many variables contribute to fluctuations in annual energy costs, including changes in square footage, building stock, weather, energy efficiency investments, service level, fuel mix, fuel prices, and vehicle, naval, and aircraft fleet composition.

NOTE: This table incorporates revisions to previously published energy consumption and cost data submitted to DOE by Federal agencies.

Source: Federal Agency Annual Energy Management Data Reports 


\section{APPENDIX D \\ BUILDINGS EXEMPTED FROM NECPA'S \\ PERFORMANCE GOAL IN FY 1997}

Section 543(a)(2) of NECPA states, "An agency may exclude from the requirements of paragraph (1) any building, and the associated energy consumption and gross square footage, in which energy intensive activities are carried out. Each agency shall identify and list in each report made under section 548(a) the buildings designated by it for such exclusion." These buildings are not included in the calculations for determining performance toward the buildings Btu/GSF reduction goals. Instead, they are included under the category of excluded buildings/process energy. The energy consumed in these buildings is included on tables and figures which show total consumption (buildings and facilities, vehicles and equipment, and excluded buildings/process).

\section{Department of Commerce}

National Institute of Standards and Technology

Gaithersburg, Maryland Sites

101 Administration

102 Gate House

202 Eng. Mech.

205 Fire Research

206 Concr. Mtrls.

220 Metrology

221 Physics Lab

222 Chemistry

223 Mtrls. Test.

224 Polymers

225 Technology

226 Building Research

230 Fluid Mech.

231 Industrial

233 Sound

235 Reactor CNRF

236 Hazards

237 Non-magnetic

238 Non-magnetic

245 Radiation

301 Supply and Pln.

302 SCWPG Cooling TWR

303 Service

304 Instr. Shops

305 Switchgear

306 Elec. Sub.

307 Chemical Waste

308 Bowman House

309 Grounds

310 Hazards Strg.

311 Grounds Strg.

411 TRF

412 Temp. Ofc
413 Temp. Ofc

415-418 Temp. Ofc

419 Temp. Childcare

Boulder, Colorado Sites

1 Radio

1A Radio Building

1B Radio Building

1C Radio Building

1D Radio Building

2 Cryogenics

2A Cryogenics - Annex A

3 Liquifier

3A Liquifier - Annex A

4 Camco

5 Camco Annex

8 Mesa Test Site

9 Gas Meter

11 Ionospheric Observatory

14 Field Strength

21 Maintenance Garage

22 Warehouse

24 Plasma Physics

24A Plasma Physics - Annex A

25 Maintenance Shops

26 Day Care Facility

27 High Frequency

National Oceanic and Atmospheric Administration

AKWO11 E.T. Shop

AKW129 Elec. Storg. Bldg. \& Fac.

AKW130 Marine Warehouse

ARM004 WFO

CAW072 SW Fisheries Cntr

CAW107 WSO 
CA4486 WSFO

COC004 WSFO

COM017 Optics Bldg \& Fac.

COM018 Lab. Bldg

COM019 Lab. Bldg

COM053 Lab. Bldg

CTE005 Chem. Storg. Bldg. \& Fac.

FLE078 Port of Miami

FLM024 WSO

HIW015 WSO

LAM048 Ofc. Bldg

MAE032 Morris Island Observ

MEE00S NWS Forecast Ofc

MOC036 WSFO

MOC037 NEXRAD Bldg

MSM011 WFO

MTW006 Radar Bldg

MTW0119 Balloon Infltn. Bldg

NCC001 Dive Locker \& Fac.
NEC008 Balloon Infltn. Bldg. \& Fac.

NMM021 WFO

NVW016 Balloon Infltn. Bldg

NY5451 30 Rockefeller Plaza

ORW012 Fire Station/WSO

ORW065 WSO

PAE013 Storage Bldg. \& Fac.

TNM006 WFO

TXM029 WSO

UTW004 Balloon Infltn. Bldg

VAE014 Antenna Deck \& Fac.

WAW052 Behavior Lab. \& Fac.

WVE002 NWS Bldg

Bureau of Census

Charlotte Computer Center

\section{Department of Defense}

Process energy use at Department of Defense (DOD) facilities, or "buildings" under the definition of PL 100-615, is separately identified from the building and facilities energy use reported under the goal of section 543. Some DOD facilities have both building and facility use, and process energy use. DOD actively manages process energy facilities in such a manner as to achieve a 10 percent energy efficiency improvement goal by FY 1995. The following lists those facilities which report process energy and are exempt from NECPA's performance goal.

$\underline{\text { Army }}$

Cold Region R\&E Lab, Hanover, NH

Dist. Engr., Huntington, WV

Dist. Engr., Jacksonville, FL

Dist. Engr., Mobile, AL

Dist. Engr., Wilmington, NC

Dist. Engr., Charleston, SC

Dist. Engr., Little Rock, AR

Dist. Engr., Galveston, TX

Dist. Engr., Rock Island, IL

Dist. Engr., Detroit, MI

Dist. Engr., Kansas City, MO

Dist. Engr., Omaha, NE

Dist. Engr., Los Angeles, CA

Dist. Engr., San Francisco, CA

Stratford Engine Plant, CT

21st SUPCOM, Germany

Dist. Engr., New York, NY

Dist. Engr., Baltimore, MD

Lima ARMODCTR, OH

Tobyhanna ARDEP, PA

Scranton AAP, PA

Radford AAP, VA

Redstone Arsenal, Huntsville, AL
V Corps, Frankfurt, Germany

Holston AAP, Kingsport, TN

Pine Bluff Arsenal, AR

Dist. Engr., New Orleans, LA

Louisiana AAP, Shreveport, LA

Sunflower AAP, Laurence, KS

Detroit Arsenal, Warren, MI

Lake City AAP, Independence, MO

Fort Leonard Wood, Waynesville, MO

Dist. Engr., Sacramento, CA

Mississippi AAP, Picayune, MS

$\underline{\text { Air Force }}$

Tyndall AFB, Panama City, FL

Rhein Main AB, Germany

Little Rock AFB, AR

Pope AFB, Fayetteville, NC

Dover AFB, DE

Offutt AFB, Omaha, NE

Beale AFB, Marysville, CA

Holloman AFB, Alamogordo, NM

Seymour Johnson AFB, Goldsboro, NC

MacDill AFB, Tampa, FL

Canon AFB, Clovis, NM

Bergstrom AFB, Austin, TX 
Davis Monthan AFB, Tucson, AZ

Mountain Home AFB, ID

Sparrevohn AFS, Alaska

Shemya AFB, Alaska

\section{$\underline{\text { Navy }}$}

NSY, Portsmouth, NH

NSY, Philadelphia, PA

NAC, Indianapolis, IN

NSY, Portsmouth, VA

NSC, Norfolk, VA

NSY, Charleston, SC

NSY, Mare Island, CA

NSC, Oakland, CA

NSC, San Diego, CA

NSY, Puget Sound, WA

NSY, Pearl Harbor, Hawaii

NAVSUBASE, Pearl Harbor, Hawaii

NSC, Puget Sound, WA

NSC, Pearl Harbor, Hawaii

NSC, Charleston, SC

NSY, Long Beach, CA

NAPC, Trenton, NJ

NSRF Guam, Marianas Islands

NSSPO, Magna, UT

NARF, Alameda, CA

NARF, Jacksonville, FL
NARF, Norfolk, VA

NARF, San Diego, CA

NARF, Pensacola, FL

NARF, Cherry Point, NC

NSPASURSTA, Chula Vista, CA

NSPASURSTA, Maricopa, AZ

NSPASURSTA, Truth or Consequences, NM

NSPASURSTA, Archer City, TX

NSPASURSTA, Lewisville, AR

NSPASURSTA, Hillandale, MS

NSPASURSTA, Wetumpka, AL

NSPASURSTA, Hawkinsville, GA

NSPASURSTA, Savannah, GA

NWIRP, Toledo, $\mathrm{OH}$

NIROP, Rochester, NY

Grumman Aerospace, Bethpage, NY

NIROP, Pittsfield, MA

NIROP, Minneapolis, MN

NIROP, Sunnyvale, CA

Allegany Ballistics Lab, Pinto, WV

NIRP, St. Paul, MN

NWIRP, Bloomfield, CT

NIROP, Pomona, CA

NWRIP, Bedford, MA

Grumman Aircraft Eng., Calverton, NY

DLA

DCSC, Columbus, $\mathrm{OH}$

\section{Department of Energy}

\section{Los Alamos National Laboratory}

Equipment Test Lab

Lab Meson Facility

Operations Bldg

Service Corridor

Accelerator Tec Bldg

LANSCE/WNR Bldg

Proton Storage Ring

High Res Beam Facility

General Purpose Lab

WNR Lab Support Facility

Warehouse

Proton Storage Staging Ring

FMIT Bldg

Acceleraior Tec BIdg

Development \& Testing

Computer Maintenance

Data Analysis Center

Accelerator Maintenance Bldg

Sub-Stockroom/Wjse

JCl Craft Shop

Proton Storage Ring Eqp
Experimental Area

Neutron Scattering Exper

NPB Technical Support

Shop \& Storage Bldg

Office Bldg

Warehouse

Office Bldg

Med Resolution Spect

Neutron Exper Service

GTA Facility

ML Neutron Scattering

322 Trailers, Transportables \& Small Service Sheds

Kansas City Plant

Industrial Wastewater Pretreatment Facility

Pantex Plant

16-4/Paint and Sand Blast

16-10/Vehicle Wash

Security Lighting 
Sandia National Laboratories, Albuquerque

(Site No. 0112)

Building 880

Building 827

858/Microelectronics Development Lab

878/Process Development Lab

Naval Petroleum and Oil Shale Reserves in Colorado, Utah, and Wyoming

Maintenance Shop

LTS Gas Plant Main Compressor Building

Steam Generator \#1 Facility

Warehouse Quonset

Water Treatment Facility

Field Core Facility

Steam Generator \#2 Facility

Steam Generator \#3 Facility

Steam Generator \#4 Facility

Steam Generator \#5 Facility

Field Operations Office

Environmental, Safety, and Health Office

Water Treatment Facility Expansion

UPS Building

LTS Gas Plant Office

Water Disposal Facility

LTS Gas Plant Shop

Polymer Plant

LTS Gas Plant PAMCO Building

LTS Gas Plant Lab

LTS Gas Plant Pump House

Fireflood Pump Building

South Terminal Main Building

South Gate Guard Shack

\section{Idaho Operations}

Utility Building

Laboratory

Transportation Complex

Service Building Powerhouse

New Waste Calcining Facility

Coal-Fired Boiler House

Coal Plant Unloading Building

Liquid Effluent Treatment and Disposal Facility

Hot Shop/Manufacturing and Assembly

SMC Manufacturing and Assembly

ATR Building

ATR Cooling Tower Pumphouse

Deep Well Pump-House \#4

Diesel Generator Building

Waste Heat Recovery Building
ICF Kaiser, Hanford Site

Riggers Loft

Tritium Vault

Tritium Laboratory

6 Reactor Facilities

Decon Station Foundation

4 Effluent Water Outfall Structures

3 Retention Basins

Filter Plant Power Operation Facility

Mechanical Development Lab (D\&D in prog-'94)

Main Pump House

Fresh Metal Storage

Development Laboratory (D \& D in Prog-'94)

Main Pump HSE-Includes North and South Annex

Biology Laboratory

ERDS Towers On Hanford Site

Warehouse

Mobile Office@105H

Change Room Trailer@105H

Mobile Office (FKA:1131N)

Mobile Office@105H

Gas Recirculation Building

2 Exhaust Air Sample Building

Power Control Building Columbia River Monitorin

Effluent Water Treatment Pilot Plant

Water Studies Semiworks Facility

Offices and Telephone Exchange

Filter Plant Head House, Chlorine

11 Office Buildings

Badge House Temporary

3 Carpenter Shops

Change Room Building

Crib Effluent Iodine Monitoring Facility

9 Storage Buildings

Demineralization Plant Building

Fuel Oil Storage Tank and Unloading Platform

Vehicle Gate Inspection Bldg

Patrol Boat House

Rivr Guard Tower

Mobile Office W. of 1167A

Process Facility

Tank Farm Waste Support Facility

Gas Preparation Building

Underground Waste Storage Tank Farm

Waste Disposal Tank Farms (4)

Tank

Tank and Vault

Radioactive Particle Research Laboratory

Cask Loading Building

Guard Station for 209E

Office Administration and Gate House

Office Administration Building

Paint Storage Building

Critical Mass Storage

Office Machine Storage 
Field Mobile @ Slab Yard

Canine Facility

Fabrication, Mockup Shop Building

Warehouse Essential Materials, NO. Of Purex

Solvent Handling Building

Filter Building

Fanhouse

Mobile Office @ 4th \& Baltimore (57B)

Graphics Facility @ 284E (ATT TO MO931)

Survey Mobile Office @ 4th \& Baltimore (2910E)

Change Room Trailer@284E

Mobile Office@202A (ATT'D TO MO948)

Mobile Office@202A (ATT'D TO MO542)

Mobile Office@ 202A (ATT'D/ID'D MO355)

Mobile Ofc@Baltimore N/O 4th

2 Mobile OFC @ Baltimore N/O 4th

1 Janitorial Storage @284E

2 Mobile Office @200 Area ETF

Mobile Office@ Baltimore N/O 4th

Mobile Office @ 4th \& Baltimore

Lunchroom Trailer@Slab Yard

Mobile Office @ 4th \&Baltimore (AKA: 2910E)

Graphics Trlr@284E (ATT MO203)

4 Mobile Office@ 4th and Baltimore (AKA:2911E)

Mobile Office@Purex

Mobile Office@202A (ATT'D/D'D AS MO347)

Mobile Office @ 224B

Office Administration Building

Office and Laboratory Building

Concentration Facility, U03 Plant

Calcination Facility

Electrican Shop

Pipefitter Storage

Pipefitter Small Shop

Gas Bottle Dock

Pipefitter Small Shop

Sheetmetal Shop

Material Storage

Insulator Shop

Paint Storage(W-25)

Laborer Storage

Non-Tracable Bench Stock Storage

Ice House

Heavy Equipment Operator Shack

Paint Mixing Shop

Paint Shop

2 Paint Storage

Mask Laundry and Office Building

Materials Engineering Laboratory

Waste Incinerator Facility

Plutonium Concentration Facility

Exhaust Filter Building

Change House

Coal Handlers Shelter

First Aid Station and Offices

Office and Service Building
PU Storage

Welding Laboratory Building

D\&D Female Change Trailor @ 271T

Chemical Storage Warehouse

Power House Stream Plant

Packaged Boiler

Water Tower

Exhaust Fan Control House and Stack

Jet Pit House

Acid Recovery and Gas Treatment Building

2 Mobile Office@2704w

Mobile Office@222T

SWP Changeroom Trailer@211U

DeconTrailer@242S

Material Evaluation Laboratory

Material Storage Building

Waste \& Material Storage

Uranium Oxide Facility

Uranium Concretion Facility

Uranium Concretion Change Room

Electrician and Pipefitter Shop

Storage

Materials Development Laboratory

2 Fuel Development Laboaratory

SP-100 Ges Tesr Facility

Emergency Storage, Part if 309 Building

N Fuel Manufacturing Support FAX.

Engineering Development Laboratory

Stress Rupture Test Facility

Hydromechanical/Seismic Facility

Model Heat Loop, Part of 321 Building

Mechanical Properties Laboratory

Chemical Engineering Building

Stack Sampling Facility

Post Irradiation Test Laboratory

Virology Laboratory

Dog Kennel

Animal Resources Storage Building

Packaging Test Facility

N Fuel Building

Waste Acid Storage Building

Waste Neutralization Facility

Waste Retention Building

Maintenance Shop

Communication and Documentation Services

Change House

Radioanalytical Laboratory

Organic Chemistry Laboratory

Spare Parts Warehouse

Materials Archive Building

Laboratory Equipment Central Pool Building

Sodium Storage Facility

Chemistry and Metal Sciences Laboratory

Classified Incinerator Facility

Fabrication Shop

Solvent and Acid Storage Building 
Emergency Air Bottle Bldg(ATT to 3701d)

Classified Vault

Geotechnicl High-Bay

Gamma Irrdiation Facility Laboratory Equipment

Central Pool

Graphite Machine Shop

Paint Storage Building

Radiological Calibrations and Standards

Electron Acclerator Facility

Irradiation Physics Building

Conference Training Building

Technical Security

Offices

Laboratory

Mobile Office 329 T.2

Mobile Office 329 T.1

Mobile Office (377 Trl 1)

Mobile Office 3760 T.1

Mobile Office $(3745 \operatorname{Trl} 1)$

Mobile Office 326 T.2

Mobile Office 306W T.2

Mobile Office 328 T.5

Mobile Office (3705 Trl 1)

Mobile Office (318 Trl 3)

Mobile Office 331 T.5

Mobile Office (323 Tr1 2)

Mobile Office (333 Trl 1)

Mobile Office 306W T.6

Mobile Office (366 Trl 4)

Mobile Office (3770 $\operatorname{Trl} 2)$

Mobile Office (3770 Trl 1)

4 Mobile Office

Mobile Office 318 T.2

Mobile Office @ FMIT

Mobile Office 325 T.1

Mobile Office 320 T.2

Mobile Office (FMIT TRL 3)

Mobile Office (FMIT TRL 5)

Escort Trailor

Mobile Office to be Excessed 7/94

Mobile Office Also Known As 377 Trl 2

HPT Office@340

Mobile Office 306W T.5

Mobile Office Shop (306 Trl 7)

Mobile Office (FMIT Trl 9)

Mobile Office N/O 4 th \& Buffalo (A Farm)

Mobile Office (FMIT Trl 4)

Mobile Office 3760 T.3

Mobile Office (FMIT Trl 10)

Mobile Office ( $3763 \mathrm{Trl} 1$ )

Mobile Office to be Excessed 10/94

Mobile Office@ESML Constr. Site

Radio Maintenance Shop(655W-AVE)

$\mathrm{X}$ Ray Facility

Sand Blast Facility

Telephone Exchange (959FIRSTST)
Hevy Equipment Repair Shop and Office

Oil Storage

Bottled Gas Storage

Fabrication Shop

Compressor Shop

Warehouse and Safety Hall

Combustible Material Storage

Administration Building

Administration and Engineering Office Bldg

Office Building (2770U-Ave)

Consolidated Personnel Building

Telecommunication Shop@1154(2671W-Ave)

Telecommunications Office@ 1154 (2675W-Ave)

Mobile Office Near 1262 Building (2730U-Ave)

Restroom Trlr@1209 Bldg Gate

Telecommunications Office@ 1154 (2665W-Ave)

Men's Restroom Trailers S. Of 1226

Previously Called Trl. 4 Near 1301

Mobile Office Att to 1154-Formerly TrIF 7

Mobile Office Near MO-850(2726U-AVE)

Field Changeroom Trailer S of 1226

2 Telecommunications Parts Storage @1154

Mobile Office@1154 (2667W-AVE)

Mobile Office (2735U-AVE)

Mobile Office Near 1226(2648W-AVE)

Mobile Office @ EMSL Site EMSL Tr.1

Visitor's Center

Training Facility

Maintenance and Storage Facility (MASF)

Former Guard Station, Kentucky Blyd

Guard Station, Grant Ave.

Guard Station, Hayes St.

Security Maintenance Shop

400 Area Fire Station

400 Area Site Support Office

Medical Aid Station

Site Service Maintenance Shop

Warehouse (Special Tools)

Warehouse

Mobile Office Of W. Of 4706

Mobile Office (Trl 100) W. Of 4706

Mobile Office (Trl 102) W Of 4706

Field Trailer W. Of 4706

Mobile Office W. Of 4706

Patrol Utiltity Building

Radioecology Field Laboratory, Rattlesnake SPRI

Space Science Laboratory

Pump House

Lysimeter Preparation Building

Ale Field Storage Building

ALE Laboratory 11

Pump House

Fallout Laboratory

Fire Protection Pump House

Mobile Office@ Grout

Escort Trailor@Gate814 
Mobile Office s/o 622G

Portable GEN/Water Tank @ CTRL Landfill

Mobile Office@243G

Boar House/Storage Building

Savannah River Operations Office

3 Pumphouses

4 Reactor Buildings

4 Area Cooling Water Pumphouses

4 Area Fuel Unloading Facilities

4 Emergency Diesel Generator/Fuel Oil Storage

Facilities

\section{Brookhaven National Lab}

Accelerator Storage

Medical Research Reactor

AGS Switchhouse

Pumphouse, Cooling Tower

Valvehouse

Equipment House

NAT Synchrotron Light Source

Gamma-Ray Beam Reactor

High Flux Beam Reactor

Cold Neutron Facility

Fanhouse

Dynam Van De Graaff

Cyclotron

Machine Shop

Tandem Van De Graaff

Magnet Development

Magnet Assembly

Electricians Work Area

Cryogenic Test Facility

Pett VI

Heavy Ion Power Supply A

Heavy Ion Power Supply B

Heavy Ion Beam Tunnel

AGSExperimental Halls

Mechanical Equipment

AGS Tunnel

Fan House A

Fan House B

Fan House C/A-10 House

Fan House D

Fan House E

Proton House D18

Proton House E18

Proton House F18

Proton House G18

Proton House $\mathrm{H} 18$

Proton House I18

Proton House J18

Proton House K18
Proton House L18

Booster Equipment House L18A

Proton House A18

Proton House B18

Proton House $\mathrm{C} 18$

H-10 Equipment House

Booster

Warehouse

7 Works Building

E-10 Power Supply

Exp. Power Supply Building G-2

Scientific Assembly

Works Building

N. Experimental Tunnel

MG Power Supply

RF Power Supply

200 MEV Linac

Irradiation Facility (Cliffo

Isotope Producer (BLIP)

F-10 House Equipment

Radiation Effects Tunnel

On-Line Data Facility

Booster Tunnel

Blip Pump House

4 Storages

Dead Storage

Experimental Computer/Electrical Building

Compressor Building

Electronic Equipment Repair

Strategic Petroleum Reserve

41 Field Instruments Buildings

5 Foam Storage Buildings

6 Control Center Buildings

Maintenance Building

Foam Storage A Building

Potable Water Building

5 Sky Switchgear Building

Maintenance Strg equipment Building

3 Soc Building

Main Guard House Building

3 Property Warehouse Buildings

4 Flammable Storage Buildings

3 Foam Deludge Building

Rwis Pump Hpuse Building

2 Gun Cleaning Building

Weld Shop Building

Grass Maintenance Equipment Building

2 Foam Generator Buildings

Maintenance Facility Building

Radio Repairer Building

Skva Supr Bloc F \& G

1 Firewater Pumps

6 Administration Buildings 
Fire Pumps on Trucks Building

Paper Recycling Building

Guard House Building

Electrical Moa Building

Substation Electrical Building

Deludge Valve Building

Moc Be-2 Building

Guard House Corner Building

3 Gun Cleaning Building

Water Storage Building

2 Motor Control Center Building

Maintenance \& Warehouse Building

Erner Properness Building

Rwis Ups Building

2 Communications Buildings

Warehouse E Building

Main Fire Water Building

Fire At Black Lake Building

ACUS Small Shed

Control Room Taxoma Building

Sky Foam Deluge Building

Fab Shed Building

Deluge Valve

Flammable Storage Shed

Guard Conet Gate Building

Ravis Microwave Building

Ravis Computer Conrno Building

Sky West Building

Sky East Building

Switchgear Building

Contruction and Maintenance Building

Sample Lab Building

Pump House Foam Building

Inert gas Gen Building

$\mathrm{P} / \mathrm{S}$ Head Frame

MOCS s/s Area Building

Equipment Storage Building

Fire Truck Building

Well Water Pump Hou Building

Fire Transformer Dei Building

Fill Site Storage Building

Maintanance Receiving Building

Lab Building

Radio Tower Building

Guard House On Site

Foam Prop. \#3 Building

Foam Prop.\#2 Building

Foam Prop. \#1 Building

Foam Prop. \#4 Building

Operator Control Dk1 Building

Operator Control Dk2 Building

Foam Prop Dock 1 Building

Firewater Pump Dk 1 Building

Foam Prop. Dock 2 Building

Property Whse/Maint Building
Vehicle Maintenance Building

Wash Rack Building

Wheeled Equip Building

Sample Storage Building

Gatehouse Front Hard Building

Gatehouse \#3 Building

Firewater Pump Building

Foam Proportioning Building

Covered Laydown Building

Rwis Guardhouse Har Building

Substation Building

Rwis Control Building

Prefab. Paint Storage Building

Rwis Comm Building

Microwave Building

HPP/Permit/Fire Pump

$\mathrm{S} / \mathrm{S}$ Hoist

S/S Head Frame

2 Property Warehouse

Warehouse D

Rwis

Warehouse Guard House

Stanford Linear Accelerator Center

Accelerator Tunnel

Klystron Gallery

Beam Switch Yard (BSY)

Damping Ring Vault, South

Damping Ring Vault, North

Damping Ring RF - South

Damping Ring RF - North

Collider Housing North Arc

Collider Housing South Arc

Power Conversion

Casting Pad Shelter

Test Laboratory

Hydrogen Furnace Housing

Deionization Plant

Main Control Center (MCC)

Cryogenics Building

Test Cell Facility

Electronics Building Annex

End Station A

Final Focus Test Beam Bldg

Final Focus Test Beam Bldg

Bubble Chamber / 40"

Bubble Chamber Bldg / 82"

Spear Interaction Area/East

Spear Control Building

Spear Interaction Area/West

SSRL, North Annex

Test Beam Facility (TBF)

SSRL South Arc Building

SSRL Lab/Office/Shop Bldg 
SSRL Spear Injector (in Const.)

Van Group D

Experimental Control C-Beam

East Pit Control Room

82" BC Support

82" BC Support

Control Room B/L 19

Cryo Eng. \& Operations

West Pit Detector Support Bldg

Beamline 6 Test Building

Final Focus Test Beam

Laser Storage Building

E 137 Experimental Building

IR 2 Hall

IR 2 Hall Annex

IR 2 Counting House

IR 2 Support Building

IR 4 Hall

IR 4 Counting House

IR 4 Support Building

IR 6 Hall

IR 6 Counting House

IR 6 Support Building
IR 8 Hall

IR 8 Support Building

IR 10 Support Building

IR 12 Hall

IR 12 Counting House

IR 12 Support Building

SSRL PBF 18

CEH SLC Experimental Hall

MkII Leach

MCC Portable Building

Light Fabrication Building

Heavy Fabrication Building

Plating Shop Annex

Vacuum Assembly Building

Light Assembly Building

EFD Shops and Storage

EFD Shop Building

Rigging Loft

PMU Shops Building

Transport Tire Shop

Electronics Shop Trailer

Research Yard Machine Shop

\section{Department of Transportation--Federal Aviation Administration}

62 Automated Flight Service Stations

Airport Information Desk

Automated International Flight Service Station

119 Approach Light Systems

Airway Beacon

127 Air Route Surveillance Radar -

FAA and Military

Air Route Traffic Control Center

189 Automated Radar Terminal Systems

23 Airport Surface Detection Equipment

647 Altimeter Setting Indicators

263 Airport Surveillance Radar -

FAA and Military

568 Airway/Terminal Building Maintenance

23 Air Traffic Control Beacon Interrogator

331 Air Traffic Control Radar Beacons

464 Airport Traffic Control Towers

398 Automatic Terminal Information Systems

356 Automated Weather Observing Systems

Aerial Tramway

597 BRITE Radar Indicator Terminal Equipment

294 Backup Emergency Communications

116 Computer Based Instruction

2 Central Computer Complexes

120 Closed Circuit TVs

229 Common Digitizers

10 Cloud Height Indicators

Computer Display Channel

Combined Center/RAPCO
11 Control Circuit Equipment

407 Control Line Maintenance

17 Communications Microwave Link Terminals

23 Command Communications Outlets

Center Building Maintenance

23 Direct Access Radar Channels

Display Channel Complex

337 Direction Finders - VHF

226 Direction Finder Indicators

584 Distance Measuring Equipment

51 Distance Measuring Equipment Remaining

558 Data Multiplexors

811 Data Terminal Equipment

En Route Automated Radar

Tracking System

5 Electronic Data Processing Systems

468 Electrical Distribution Systems

12 Emergency Operating Facilities

50 Flight Data Entry and Printout

23 Flight Data Input/Output Centers

391 Flight Data Input/Output Remotes

Flight Data Remoting System Intermediate

Fields and Landing Areas

39 Fan Markers

20 Flight Service Data Processing Systems

189 Flight Service Stations

46 Ground/Air Transmitter Receivers

Guidance Light Facility

Gap Filler Radar 
85 Geostationary Operational

Environmental Satellite Systems

864 Glide Slopes

1143 Homing Radio Beacons

5 Central Heating Facilities - Per Unit

22 Heliports

Homing Radio Beacon - High Power

1 International Aeronautical

Telecommunications Switching Center

260 Integrated Communications

Switching Systems

26 Identification, Friend or Foe

International Flight Service Station

International Flight Service

Transmitter Station

81 Inner Markers

136 VHF/UHF Link Terminals

23 Localizer Type Directional Aids

20 Lead-in Light Facilities

37 Living Quarters

114 Low Level Wind Shear Alert Systems

Compass Locator at the ILS

Middle Marker

4 Link Repeaters

1053 ILS Localizers

473 Compass Locators at the ILS

Outer Marker

94 Medium-Intensity Approach

Lighting Systems

633 Medium-Intensity ALS (MALS)

with Runway Alignment

Indicator Lights (RAIL)

4 Meteorological and Aeronautical

Presentation Systems

9 Marine Equipment Boats and Docks

625 Multichannel Recorders

17 Military Height Finder Radar

33 Military Interface Groups

Military Interface Modification

272 Microwave Landing Systems

Azimuth

160 Microwave Landing Systems

Back Azimuth

271 Microwave Landing System Distance

Measuring Equipment Precision

276 Microwave Landing System Elevation

1 Microwave Landing System Flare

828 Middle Markers

14 Mobile Laboratories

105 Mode S/Data Links

46 Maintenance Processing Systems

400 Mobile Engines or Generator Plants

28 National Data Interchange Networks

1282 National Radio Communications Systems
39 Next Generation Weather Radar

65 Off Airways Weather Stations

50 Omnidirectional Airport Lighting Systems

Oceanic Display and Planning System

325 Heavy Equipment and Off-Road Vehicles

831 Outer Markers

General Oil Distribution System

180 Precision Approach Path Indicators

2 Precision Approach Radar

707 Power Conditioning Systems

19 Primary Power Engines or Generator Plants

68 Quarters Building - Other than

Living Quarters

8 Radar Approach Control - Air Force

111 Rotating Beam Ceilometers

11 Radar Bright Display Equipment

22 Radar Beacon Data Processor Equipment

277 Remote Beacon Performance Monitor

685 Remote Center Air/Ground

Communications Facilities

99 Remote Control Interface Units

752 Rádio Communications Link Repeat

233 Radio Communications Link Terminals

1837 Remote Communications Outlets

692 Runway End Identification Lights

215 Remote Monitor Control Facilities

214 Radar Microwave Link Repeaters

138 Radar Microwave Link Terminals

189 Remote Readout Hygrothermometers

95 Radar Remote Weather Display Indicators

135 Radar Remote Weather Display Systems

12 Remote Tower Communications

Control Systems

1222 Remote Transmitter Receivers

537 Runway Visual Range

Shortened Approach Light System

Sanitation System

661 Storage Buildings

Systems Command Center

Sensor, Receiver, and Processor

72 Simplified Short Approach Lighting

Systems with Runaway Alignment

Indicator Lights (RAIL)

Simplified Short Approach Lighting System

Self Sustained Outlet

49 Sewerage Systems

666 Tactical Air Navigation

8 Tower Cab Digital Displays

144 Terminal Data Display Systems

496 Telephone Exchanges

589 TELC Interface Maintenance

19 Terminal Information Processing Systems

125 Television Microwave Link Indicators

110 Television Microwave Link Repeaters

138 Television Microwave Link Transmitters 
414 Tower Buildings

529 Trails and Ruads

25 Terminal Radar Approach Controls

17 Teletypewriter Facilities

137 Transcribed Weather Broadcast

743 Utility Buildings
1387 Visual Approach Slope Indicators

769 Vehicle Maintenance

1025 VHF Omnidirectional Range

95 VHF Omnidirectional Range Test

Weather Message Switching Center

Water System Maintenance

\section{General Services Administration}

Region 1

GSA Cd Depot 234, Watertown, MA

Federal Building, Lowell,MA

EPA Laboratory, Lexington, MA

US Border Station, Calais, ME

US Border Station, Coburn Gore, ME

US Border Station, Fort Fairfield, ME

28 Lord Road, Marlborough, MA

US Border Station, Houlton, ME

US Border Station, Jackman, ME

US Border Station, Limestone, ME

US Border Station, Orient, ME

US Border Station, Vanceboro, ME

US Border Station, Van Buren, ME

US Border Station, Calais, ME

USBS,St.Pamhille, Saint Francis, ME

US Border Station, Madawaska, ME

USBP Sec Hd Houlton, Hodgdon, ME

Parking Facility, Portland, ME

US Border Station, Fort Kent, ME

Warren B. Rudman, Concord, NH

USBS Highgate Springs, VT

US Border Station, Derby Line, VT

US Border Station, Highgate Springs, VT

US Border Station, Norton, VT

US Border Station, Beebe Plain, VT

US Border Station, Alburg Springs, VT

US Border Station, North Troy, VT

US Border Station, West Berkshire, VT

US Border Station/USPO, Derby Line, VT

US Border Station, Beecher Falls, VT

US Border Station, Canaan, VT

US Border Station, East Richford, Richford, VT

US Border Station, Richford, VT

Border Station, Sector Hdqtrs, Swanton, VT

US Border Station, Twp20, Saint Francis, ME

US Border Station, Township 11, Saint Francis, ME

Swanton Bdr Ptl Building, Highgate Springs, VT

Region 2

3000 JFK Blvd., Jersey City, NJ

FB, New York-Kings, NY

Border Station, Rouses Point, NY

Mech Equip Garage, Champlain, NY

Corporate Place, Rochester, NY

17 Cronin Road,Glens Falls, NY
10 Bouck Ct, New York-Kings, NY

25-27 East Park Ave., Long Beach, NY

80-02 Q Gardens, New York-Queens, NY

Century Mall, Amherst, NY

16 Court St. Bklyn, New York-Kings, NY

B\&B Bldg, San Sebastian, PR

Nazario Building, San German, PR

AL Cohen Plaza, Charlotte Amalie, VI

US Border Station, Champlain, NY

Inspection Bld Borde, Chateaugay, NY

Main Inspector Station, Massena, NY

Inspection Building, Mooers, NY

US Border Station, Fort Covington, NY

US Border Station, Rouses Point, NY

US Border Station, Trout River, NY

Administration Building, Alexandria Bay, NY

Gateway I, Newark, NJ

W/S Jamiesons Line, Burke, NY

Quaker Village, Glenn Falls, NY

NY5 Washington Sq Alba, Albany, NY

Greenway Plaza, Melville, NY

76 Eleventh Avenue, New York, NY

Mayaguez Mall, Mayaguez, PR

Region 3

Annapolis Comm. P.K.E, Annapolis, MD

Gwynn Oak Building, Woodlawn, MD

Federal Building 01, Philadelphia, PA

The Metro Center, Philadelphia, PA

5000 Wissahickon Ave., Philadelphia, PA

Erie Library, Erie, PA

Custom House, Norfolk, VA

Berris Plaza, Philadelphia, PA

Gateway, Philadelphia, PA

Wise County Plaza, Wise, PA

FairGrounds Dist Ctr, Richmond, VA

Region 4

FB PO, Port Gibson, MS

Battlefield Mall, Vicksburg, MS

Judicial Building, Biloxi, MS

MICC-DEA Warehouse, Miami, FL

E Pointe Bus Ctr, Jacksonville, FL

Cobb Corporate Ctr, Marietta, GA

BP Building, Macon, GA

Courthouse Annex, Columbia, SC 
Region 5

Illini Fin Center, Springfield, IL

GSA Interag Mtr Pool, Chicago, IL

US Border Station, Sault Ste Marie, MI

Fed Parking Facility, Detroit, MI

Cust Cargo Insp Fac, Detroit, MI

US Border Station, Grand Portage, MN

Custom \& Immig Stat, Noyes, MN

US Border Station, International Falls, MN

Federal Building, Medina, $\mathrm{OH}$

Federal Building, Zanesville, $\mathrm{OH}$

Fed Parking Facility, Dayton, $\mathrm{OH}$

Bankers Building, Chicago, IL

Social Security Building, Danville, IL

Park Ridge Ofc Ctr, Park Ridge, IL

O'Hare Lake Ofc Plz, Des Plaines, IL

Insurance Exchange $B$, Chicago, IL

Plaza Tower Office, Evergreen Park, IL

Clyde Savings Building, North Riverside, IL

2100 N California, Chicago, IL

Wash Bicentennial Bg, Springfield, IL

Smoke Tree Bus Park, North Aurora, IL

Glen Hill North Bg A, Glen Ellyn, IL

10 West Jackson Blvd, Chicago, IL

O'Hare Lake Off. Pla, Des Plaines, IL

One Congress Center, Chicago, IL

E Empire \& Eastport, Bloomington, IL

Burrell Building, Chicago, IL

Oakmont Corporation, Westmont, IL

1455 Golf Mill Road, Des Plaines, IL

1279 North Milwaukee, Chicago, IL

Bank Of America, Chicago, IL

901 Warrenville Road, Lisle, IL

1700 South Wolf Road, Des Plaines, IL

Elm Plaza So. Tower, Hinsdale, IL

Soc. Sec. Office, Chicago, IL

125 Fairfield Way, Bloomingdale, IL

IL Business Center, Springfield, IL

2360 E. Devon Ave., Des Plaines, IL

923-25 Dillon, Wood Dale, IL.

River Center, Chicago, IL

Schaumburg Atrium, Schaumburg, IL

600 Joliet Rd, Willowbrook, IL

2350 E. Devon, Des Plaines, IL

Gateway IV, Chicago, IL

Citicorp Center, Chicago, IL

Liberty Business Park, Elk Grove Village, IL

29 North Wacker Drive, Chicago, IL

Governors' Off. Park, Olympia Fields, IL

One Oakbrook Terrace, Oakbrook Terrace, IL

Xerox Centre, Chicago, IL

Stewart Square, Rockford, IL

635 Butterfield Rd, Oakbrook Terrace, IL

Governors Off Pk IV, Olympia Fields, IL

Glenwood Plaza, Glenwood, IL

Northwestern Building, Evanston, IL
The Rookery, Chicago, IL

1600 Corporate Cntr, Rolling Meadows, IL

4849 N. Milwaukee Av, Chicago, IL

AT\&T Corporate Cntr, Chicago, IL

801 Warrenville Road, Lisle, IL

1000 Tower Lane Building, Bensenville, IL

Olympian Office Cntr, Lisle, IL

The Park at NW Point, Elk Grove Village, IL

945 Lakeview Parkway, Vernon Hills, IL

2860 River Road, Des Plaines, IL

One S. Wacker Building, Chicago, IL

Governors Office Pk, Olympia Fields, IL

Fox River Center, Ottawa, IL

1600 Lebanon Avenue, Belleville, IL

Lakeside Ofc Building, Indianapolis, IN

429 Penn Center, Indianapolis, IN

The Furniture Co., Grand Rapids, MI

Ambassador Bridge, Detroit, MI

Arlington Plaza, Sault Ste Marie, MII

5015 South Cedar Str, Lansing, MI

Domino's Farm House, Ann Arbor, MI

Brewery Park Phase I, Detroit, MI

Plaza Nine Building, Cleveland, $\mathrm{OH}$

Commerce Place, Middleburg Heights, $\mathrm{OH}$

Plaza South I, Middleburg Heights, $\mathrm{OH}$

Sanning Apartments, Cincinnati, $\mathrm{OH}$

One Cleveland Ctr, Cleveland, $\mathrm{OH}$

Lakewood Center West, Lakewood, $\mathrm{OH}$

Plaza South I, Middleburg Heights, $\mathrm{OH}$

2026 West Main Stree, Springfield, OH

Corporate Center, Middleburg Heights, $\mathrm{OH}$

4411 Montgomery Road, Norwood, $\mathrm{OH}$

CBLD Building, Cincinnati, $\mathrm{OH}$

Bank One Center, Cleveland, $\mathrm{OH}$

Eaton Center, Cleveland, $\mathrm{OH}$

Wright Executive Ctr, Fairborn, $\mathrm{OH}$

Renaissance, Cleveland, $\mathrm{OH}$

228th \& Lake Shore B, Euclid, $\mathrm{OH}$

Society Tower, Cleveland, $\mathrm{OH}$

6161 Oaktree, Independence, $\mathrm{OH}$

Rockside Center III, Independence, $\mathrm{OH}$

Old Bayfield Cthse, Bayfield, WI

Social Security Off, Wisconsin Rapids, WI

Vander Heyden II, West Bend, WI

575 Lester Street, Onalaska, WI

1830 2nd Ave. Rock Island, IL

Midway Business Ctr, Chicago, IL

5353 S. Laramie, Chicago, IL

Illinois Financial Ctr, Springfield, IL

Burr Ridge Executive, Burr Ridge, IL

Lucy and Water St., Saugatuck, MI

IRS Data Center, Pontiac, MI

Pontiac Place Building, Pontiac, MI

Social Security Building, West Branch, MI

Federal Building, Redwood Falls, MN

Federal Building Courthouse, Minneapolis, MN 
U.S. Courthouse, Minneapolis, MN

Building 201, St. Paul, MN

Custom and Immigration Stat., Baudette, MN

Moraine Business Center II, Moraine, $\mathrm{OH}$

Moraine Business Center III, Moraine, $\mathrm{OH}$

Peck Engraving Co., Lakewood, $\mathrm{OH}$

The Esplanade, 2001Butterfield Rd,

Downers Grove, IL

1207 Network Centre Blvd, Effingham, IL

IRS Data Center, Detroit, MI

BP America Building. Cleveland, OH

Ace Industrial Dr., Cudahy, WI

FWS Center, Onalaka,WI

700 Regent St, Madison,WI

Region 6

$T$-Hangar " $G$ ", Grand Island, NE

2610 Ave "Q", Kearney, NE

US Courthouse, Kansas City, MO

Herbert Hoover Library, West Branch, IA

Eisenhower Library, Abilene, KS

U.S. Geological Survey Building, Rolla, MO

2323 Grand Building, Kansas City, MO

\section{Region 7}

USBP Sh Building 13, New Orleans, LA

Open Land - FDA Site, New Orleans, LA

US Border Station, Columbus, NM

USBS, Santa Teresa, NM

Federal Building, Altus, OK

USBS B\&M Bridge, Brownsville, TX

Gateway USBS Building A, Brownsville, TX

Columbia USBS, Laredo, TX

US Border Station, Laredo, TX

USBS Admin Building, Del Rio, TX

BPSH Building 1, Hqtrs, Del Rio, TX

USBS Br Of The Amers, El Paso, TX

U S Border Station, Eagle Pass, TX

Juarez-Lincoln USBS, Laredo, TX

USBS Admin Building, Los Indios, TX

BPSH Building A, Laredo, TX

BPSH Administratn Bd, McAllen, TX

Headquarters Building, Marfa, TX

USBS Paso Del Norte, El Paso, TX

USBS Main Building, El Paso, TX

USBS Good Neighbr Br, El Paso, TX

Unnamed Building, Fort Smith, AR

Unnamed Building, Metairie, LA

Building 27, Houma, LA

Sun Belt Buis Ctr, Albuquerque, NM

SSA District Office, Poteau, OK

US Border Sta -New, Hidalgo, TX

US Border Station, Progreso, TX

US Border Station, Rio Grande City, TX

US Border Station, Presidio, TX
Unnamed Building, Laredo, TX

Vicar Center, San Antonio, TX

USBS IntI Rr Land, Laredo, TX

T \& P Building, Fort Worth, TX

USBS Admin Building, Hidalgo, TX

Chase Plaza SVC CTR, Oklahoma City, OK

USBS Pharr Admin BId, PHARR, TX

USBS Paso Del Norte, El Paso, TX

USBS Admin Building, Progreso, TX

USBS Admin Building, Roma, TX

GEO H Mahon FB CTHS, Lubbock, TX

Region 8

GSA Parking Lot, Denver, CO

Chief Mtn BS \& Qtrs, Babb, MT

Piegan BS \& Qtrs, Babb, MT

Roosville BS, Eureka, MT

Sweetgrass BS, Sweetgrass, MT

Bdr Patrol Sector HQ, Havre, MT

Turner BS, Turner, MT

Ambrose BS, Ambrose, ND

Dunseith BS, Dunseith, ND

Portal BS, Portal, ND

St John BS, St John, ND

Pembina BS, Pembina, ND

GSA Storage Building, Bismarck, ND

Bdr Patrol Sector HQ, Grand Forks, ND

New Parking Lot, Bismarck, ND

Sunbeam Appl Svc, Salt Lake City, UT

Garage, Cheyenne, WY

Tatum Parking Lot, Helena, MT

Region 9

US Border Station, Lukeville, AZ

BS Old Cus Building, Nogales, AZ

BS Garage, Sasabe, AZ

BS Main Building, Douglas, AZ

Bdr Patl Sector Hqrs, Tucson, AZ

BS Main Building, San Luis, AZ

BS Main Building, Naco, AZ

BS Office Building, Nogales, AZ

Tucson L. E. Site, Tucson, AZ

BS Old Customs Building, Calexico, CA

BS Exist Main Building, San Diego, CA

BS Main Building, Andrade, CA

BS Main Building, Tecate, CA

US Border Patrol Sta, Calexico, CA

Federal Building, Sacramento, CA

Parking Garage, Los Angeles, CA

Motor Pool, San Francisco, CA

1303 Albee Street, Eureka, CA

Building 1, Flagstaff, AZ

NPS Building, Grand Canyon, AZ

Buildings 4 \& 5, Flagstaff, AZ

Sorrento Exec Plaza, San Diego, CA

15650 Devonshire Street, Los Angeles, CA 
Region 10

Dalton Cache Bor Sta, Haines, AK

Station Building, Tok, AK

Int Ag Motor Pool, Anchorage, AK

Skagway Border Stat, Skagway, AK

US Border Station, Eastport, ID

US Border Sta New, Porthill, ID

Station Building No.1 \& 2, Blaine, WA

Danville Border Sta, Danville, WA

Station \& Quarters, Curlew, WA

Station, Laurier, WA

Station, Metaline Falls, WA

US Border Station, Oroville, WA

US Border Station, Sumas, WA

Building 601, Walla Walla, WA

Kenneth G. Ward BS, Lynden, WA

US Border Station, Point Roberts, WA

Border Patrol Sect HQ, Blaine, WA

Border Patrol Sect HQ Annex, Blaine, WA

Border Patrol Sect HQ, Spokane, WA

Miuw Facility, Portland, OR

U.S. Courthouse, Portland, OR

USDA Building, Blaine, WA

Operations Building, Moses Lake, WA

Border Patrol Sec HQ Annex, Blaine, WA
Region 11

FOB 6, Washington DC

White House, Washington DC

Delasalle, Avondale, MD

1800 G Street NW, Washington DC

Doggett Building, Washington DC

Central Htg Plant Stm., Washington DC

West Htg Plant Stm., Washington DC

U.S. International Tr, Washington DC

1724 F Street NW, Washington DC

Reagan Building FOB, Washington DC

6014 th St, NW, Washington DC

Universal, Washington DC

Penn-Belt Center, Forrestville, MD

9620 Medical Center, Rockville, MD

Manor Business Ctr, Landover, MD

Census Computer Fac., Bowie, MD

5000 Philadelphia Way, Lanham, MD

Mat Land Co Office \& Lab, Glendale Heights, MD

Rockwall Building, Rockville, MD

Herndon Industrial Park, Herndon, VA

7405 \& 7407 Lockport, Lorton, VA

Poplar Run Park Builing 5, Alexandria, VA

Gunston Industrial Park C, Arlington, VA

Arlington Center, Arlington, VA

AV Bryan Sr Courtshe, Alexandria, VA

\section{National Aeronautics and Space Administration}

Ames Research Center (ARC)

Computational Fluid Dynamics Building

Vertical Gun

3.5 Ft. Wind Tunnel Model Building

12 Ft. Pressure Wind Tunnel

12 Ft. Wind Tunnel Auxiliaries

Propulsion Simulations Calibration Laboratory

Ballistic Range

Flight Support Facility

Model Development Facility

$7 \times 10 \mathrm{Ft}$. Wind Tunnel \#1

$7 \times 10$ Ft. Wind Tunnel \#2

Model Preparation Facility

Model Assembly

Magnetic Calibration Laboratory

Magnetic Test Laboratory

$14 \mathrm{Ft}$. Transonic Wind Tunnel

14 Ft. Electrical Equipment Building

Fan Blade Shop

Technical Services Shop

$40 \times 80$ Ft. Wind Tunnel

20-G Centrifuge

$80 \times 120 \mathrm{Ft}$. Wind Tunnel

$2 \times 2$ Ft. Transonic Wind Tunnel

Electrical Substation
Electrical Substation North

6x6 Ft. Supersonic Wind Tunnel

Unitary Plan Wind Tunnel Building

$11 \mathrm{Ft}$. Transonic Wind Tunnel

$9 \times 7$ Ft. Subsonic Wind Tunnel

$8 \times 7$ Ft. Subsonic Wind Tunnel

Unitary Plan Wind Tunnel Auxiliary Building

3.5 Ft. Hypersonic Wind Tunnel

3.5 Ft. Hypersonic Wind Tunnel Auxiliary Building

3.5 Ft. Hypersonic Wind Tunnel Storage Building

Fluid Dynamics Laboratory

Central Computation Facility

Advanced Computation Facility

Thermal Protection Facility

Thermal Protection Boiler

Bioscience Laboratories

Hypervelocity Free Flight Facility

Arc Jet Facility

Life Sciences Research Laboratory

Life Sciences Equipment Facility

Airborne Missions/Life Science Facility

Vestibular Research Facility

Vertical Motion Simulator

Vertical Motion Simulator Equipment Facility

Space Projects Facility

Space Sciences Research Laboratory 
Model Construction Facility

Aircraft Service Facility

Aircraft Service Facility

Aircraft Service Facility

RSRA Calibration Facility

Aircraft Service Facility

Outside Aerodynamic Research Facility

High Pressure Air Housing

Propane Facility

Program Support Communication Network Facility

Flight Data Complex

Flight Data Facility

Man-Vehicle System Research Facility

Numerical Aeronautics Simulator

High Altitude Aircraft Support Facility

Fluid Mechanics Laboratory

Biomedical Research Laboratory

Human Performance Research Laboratory

Hazardous Material Storage Facility

Automated Sciences Research Facility

NASA Industrial Plant (Downey) and USAF Plant

42, Production Site 1 (Palmdale)

Entire Facilities are Mission Variable

Goddard Space Flight Center (GSFC)

Central Flight Control Range

Construction/Development Laboratory

Payload Testing Facility

Environmental Testing Laboratory

Network Control Center

Spacecraft Operations Facility

Data Interpretation Laboratory

Spacecraft Systems Development/Integration Facility

EOS/DIS Building

Goddard Geophysical and Astronomical Observatory Area

Jet Propulsion Laboratory (JPL)

Environmental Laboratory

$25 \mathrm{Ft}$. Space Simulator

Spacecraft Assembly Facility

Space Flight Operations Facility

10 Ft. Space Simulator

Space Flight Support

Frequency Standards Laboratory

Earth \& Space Sciences Laboratory

Micro Devices Laboratory

Johnson Space Center (JSC)

Flight Operations Support
Flight Operations

Jake Garn Simulator and Training

Crew Systems Laboratory

Photographic Technology Laboratory

Central Data Office

Avionics Systems Laboratory

Central Heating \& Cooling Plant

Auxiliary Chiller Facility

Mission/Space Station Control Center

Planetary \& Earth Sciences Laboratory

Space Environment Simulation Laboratory

Mission Simulation Development Facility

Life Sciences Laboratory

Central Computer Facility

Emergency Power Building

Vibration and Acoustic Test Facility

Atmospheric Re-Entry Materials \&

Structures Evaluation Facility

Radiant Heat Facility

Thermochemical Test Area

Kennedy Space Center (KSC)

Hangar L, Life Sciences Support Facility

Hangar AE, Missile Assembly Building

Robot Wash

Manufacturing Building

Launch Complex 39 A \& B

Communication Distribution \& Switching Center

Operations Building

Operations and Checkout Building

Space Station Processing Facility

Hypergol Module Process North

Hypergol Support Building

Payload Spin Test Facility Replacement

Spacecraft Assembly \& Encapsulation Facility

Hypergol Module Process South

Payload Hazardous Service Facility

Vertical Processing Facility

Central Instrumentation Facility

Langley Research Center (LaRC)

8 Ft. Transonic Pressure Tunnel

University of Virginia and ART Management Office

Building

$30 \times 60 \mathrm{Ft}$. Tunnel

Transonic Dynamic Tunnel

Hydrodynamics Research Facility

Space Environmental Effects Laboratory

16 Ft. Transonic Tunnel.

Subsonic Tunnel Offices

High Speed $7 \times 10$ Ft. Tunnel

$14 \times 22 \mathrm{Ft}$. Subsonic Tunnel

Central Heating and Steam Generation Plant 
Conference Center

Anechoic Noise Facility

Hypersonic Propulsion Facility

High Intensity Noise Research Laboratory

Frequency Converter Building

National Transonic Facility (NTF)

NTF Tunnel Model Storage

Foundry \& Glass Blowing Shop

Drive Control Facility

0.3 Meter Transonic Cryogenic Tunnel

Gas Dynamics/Fluid Mechanics Research Facility

Hypersonic Facilities Complex - West Wing

Hypersonic Facilities Cooling Tower

Hypersonic Facilities Complex - East Wing

Compressor Station

60-Inch M18 Helium Tunnel Facility

Vacuum Pumping station - Gas Dynamics Complex

Atmospheric Sciences/Systems Development

Laboratory

Atmospheric Sciences Laboratory Annex

Unitary Wind Tunnel

$8 \mathrm{Ft}$. High Temperature Tunnel

Central Scientific Computing Facility

Flight Simulation Laboratory

Central Scientific Computing Facility

EOSDIS-DAAC Facility

Lewis Research Center (LeRC)

Engine Research Building

Chemistry Laboratory

Icing Research Tunnel

Special Projects Laboratory

Materials Research Laboratory

Materials \& Structures Laboratory

Central Air Equipment Building

Instrument Research Laboratory

Engine Research Building Combustion Air Heater

Engine Components Research Laboratory

Materials Processing Laboratory

Basic Materials Laboratory

Aero-Acoustic Propulsion Laboratory

\& Control Room

PSL Heater Building

Electric Power Laboratory

Energy Conversion Laboratory

Space Power Research Laboratory

$8 \mathrm{X} 6 \mathrm{Ft}$. Supersonic Wind Tunnel

10 X 10 Ft. Supersonic Wind Tunnel

Operations/Integration Building

Marshall Space Flight Center (MSFC)

Microwave Anechoic Chamber

Communications Facility
Photographic Laboratory

SSME - Block II Facility

LIDAR Facility

Power Systems Laboratory

MAST/FSL Simulation Facility

Space Science Labortory

Laboratory \& Office Building

Test Stand Support Building

Test Facility 300

Test Facility 116

Structural Test Facility

Test Facility Terminal Building

Hot Gas Test Facility

Test Control and Service Building

TPTA Refurbishment Facility

Pump and Boiler House

Propulsion and Structural Test Facility

Test \& Data Recording Facility

Space Environmental Effects Laboratory

Materials \& Processes Laboratory

Atmospheric Research Facility

Heat Treatment Facility

Structural Dynamics \& Thermal Vacuum Laboratory

Hydrogen Test Facility

Air Compressor Building

High Pressure Test Facility

Multi-Purpose High Bay Facility

Hydraulic Equipment Development Facility

LH2 Vaporization Facility

High Pressure GN2 Facility

Boiler Plant

Computer Facility

Pump House

Advanced Engine Test Facility

Test Support Building

Block House

Boiler House

Helium Compressor Building

Non-Destructive Evaluation Laboratory

Shops \& Neutral Buoyancy Simulator

Productivity Enhancement Facility

Engineering \& Developmental Laboratory

Developmental Processes Laboratory

$X-R a y ~ C a l i b r a t i o n$ Facility

Office and Wind Tunnel

Compressed Air Facility

Air Compressor Facility

High Bay Shop Building

Space Station Development Laboratory

Surface Treatment Facility

High Reynolds Number Facility

Low Density Flow Facility

Engine Dynamic Fluid Flow Facility 
Michoud Asssembly Facility (MAF)

Entire Facility is Industrial

Plum Brook Station (PBS)

Entire Facility is Mission Variable

Santa Susana Field Laboratory (SSFL)

Entire Facility is Mission Variable

\section{Tracking Stations}

Deep Space Network, Goldstone, CA
TDRSS Ground Terminals, White Sands, NM

STDN Site, Ponce de Leon, FL

Wallops Flight Facility (WFF)

Radar Facility

Machine Shop - Fabrication

Aircraft Projects/Hangar Area

Electronics Support/Storage

Mainland/Island

White Sands Test Facility

Altitude Simulation System (Steam Generator)

Diesel Pad

\section{Panama Canal Commission}

Marine Bureau ( 159 buildings)

Lock chambers

Electrical towing locomotives

Canal navigational lighting

Computerized marine traffic control

Repair facilities

Related infrastructure

Engineering \& Construction Bureau ( 257 buildings)

Industrial sector
Tug, locomotive, and dredging-related equipment repair shops

Potable water processing

Communication

Utility services

General Services Bureau (239 buildings)

Vehicle maintenance and repair shops

Fire stations

Sanitation and grounds management facilities

High energy-consuming activities

\section{U.S. Information Agency}

Relay Station, Greenville, North Carolina

Relay Station, Delano, California

Relay Station, Dixon, California (inactive)

Relay Station, Bethany, Ohio

Relay Station, Munich, Germany

Relay Station, Kavala, Greece

Relay Station, Rhodes, Greece
Relay Station, Bangkok, Thailand

Relay Station, Tangier, Morocco

Relay Station, Colombo, Sri Lanka

Relay Station, Botswana

Relay Station, Belize

Relay Station, Philippines

\section{U.S. Department of Agriculture}

242 Barns

2 Bus Stations

87 Chemical Storage Buildings

8 Engineering Facilities

4 Filling Stations

5 Fire Stations

479 Greenhouses

76 Garages

98 Headhouses

137 Housing Buildings

2 Incinerator Buildings

514 Laboratory Buildings
78 Office Buildings

85 Office/Laboratory Buildings

Chapel

6 Restroom Buildings

215 Sheds

158 Shops

426 Storage Buildings

54 Trailers

Weather Station

2 Waste Treatment Buildings

494 Other Building Types 


\section{U.S. Department of Justice}

FBI Headquarters, J. Edgar Hoover Building

FBI Academy, Quantico

FBI Miami

FBI Western Region
FBI West Virginia Complex

Justice Data Center, Washington, DC

Immigration \& Naturalization Service Repeater

Stations - Nationwide

\section{U.S. Department of State}

Main State Complex

Blair House Complex
Beltsville Information Management Center International Chancery Center

\section{National Archives and Records Administration}

National Archives Building, Washington DC, National Archives at College Park, MD

Herbert Hoover Library, West Branch, IA

Harry S. Truman Library, Independence, MO

Dwight D. Eisenhower Library, Abilene, KS

Lyndon B. Johnson Library, Austin, TX
Gerald R. Ford Library, Ann Arbor, MI

Gerald R. Ford Museum, Grand Rapids, MI

Jimmy Carter Library, Atlanta, GA

Ronald Reagan Library, Simi Valley, CA

John Fitzgerald Kennedy Library, Boston, MA

Franklin D. Roosevelt Library, Hyde Park, NY

\section{Social Security Administration}

National Computer Center, Baltimore, MD 


\section{APPENDIX E \\ DEPARTMENT OF ENERGY: EDUCATION, EXTENSION, AND INFORMATION SERVICES}

Energy Efficiency and Renewable Energy Clearinghouse (EREC)

Contact: Pat Rose, (202) 586-9645

Office of Public Affairs

Contact: F. Chester Gray, (202) 586-6827

Industrial Assessment Center (IAC) Program

Contact: Charles J. Glaser, (202) 586-1298

Energy-Related Inventions Program (ERIP)

Contact: Rolf Butters, (202) 586-1479

Gas Mileage Guide

Contact: Shelia Perez, (202) 586-6723

National Energy Information Center, Energy Information Administration (NEIC/EIA)

Contact: Sandra Wilkins, (202) 586-1173

Office of Federal Energy Management Programs (FEMP)

Contact: John Archibald, (202) 586-5772

Office of Scientific and Technical Information (OSTI)

Contact: Brian Hitson, (423) 576-1199

Technical Information Program, National Renewable Energy Laboratory (NREL)

Contact: Nancy Reece, (303) 275-3688

State Energy Program

Contact: Michelle Brown, (202) 586-2377

Technical Information and Communication Program

Contact: Marsha Quinn, (202) 586-2097

Weatherization Assistance Program

Contact: Jean Diggs, (202) 586-8295 



\section{APPENDIX F \\ FEDERAL INTERAGENCY ENERGY POLICY COMMITTEE \\ "656" COMMITTEE \\ FY 1997}

Committee Chair

Mr. Dan W. Reicher

Assistant Secretary

Energy Efficiency and Renewable Energy

U.S. Department of Energy, EE-1

Forrestal Building, Room 6C-016

1000 Independence Avenue, SW

Washington, DC 20585

Phone: 202-586-9220

Fax: 202-586-9260

\section{Agriculture}

Mr. Pearlie Reed

Assistant Secretary for Administration

U.S. Department of Agriculture

Administration Building, Room 240W

14th and Independence Avenue, SW

Washington, DC 20250-0103

Phone: 202-720-3590

Fax: 202-720-2191

\section{Commerce}

Mr. Scott Gould

Chief Financial Officer and

Deputy Assistant Secretary for Administration

U.S. Department of Commerce

Main Commerce, Room 5830

14th and Constitution Avenue, NW

Washington, DC 20230

Phone: 202-482-4951

Fax: 202-482-3592

Defense

Mr. John Goodman

Deputy Under Secretary of Defense

Industrial Affairs and Installations

3330 Defense Pentagon, Room 3E-1074

Washington, DC 20301-3330

Phone: 703-697-0051

Fax: 703-695-4277

Education

Mr. Gary J. Rasmussen

Director for Management

U.S. Department of Education

600 Independence Avenue, SW, Room 2164

Washington, DC 20202

Phone: 202-401-0470

Fax: 202-401-0485
Environmental Protection Agency

Mr. John C. Chamberlin

Director Office of Administration and Resources Management

Environmental Protection Agency

Room 1109 West Tower, MS3201

401 M Street, SW

Washington, DC 20460

Phone: 202-260-8400

Fax: 202-260-8408

General Services Administration

Mr. Robert A. Peck

Commissioner of Public Buildings Service

General Services Administration

Room 6344

18 th and F Streets, NW

Washington, DC 20405

Phone: 202-501-1100

Fax: 202-219-2310

Health and Human Services

Mr. John Callahan

Assistant Secretary

for Management and Budget

U.S. Department of Health

and Human Services

Hubert H. Humphrey Building,

Room 416-G

200 Independence Avenue, SW

Washington, DC 20201

Phone: 202-690-6396

Fax: 202-690-5405

Housing and Urban Development

Mr. Willie Gilmore

Deputy Assistant Secretary for Administration

U.S. Department of Housing and

Urban Development

Room 10110

4517 th Street, SW

Washington, DC 20410

Phone: 202-708-0940

Fax: 202-619-8129 
$\underline{\text { Interior }}$

Mr. Brooks B. Yeager

Acting Assistant Secretary for Policy,

Management and Budget

U.S. Department of the Interior

Mail Stop 6130, Room 6130

1849 C Street, NW

Washington, DC 20240

Phone: 202-208-4203

Fax: 202-208-4561

$\underline{\text { Justice }}$

Mr. Stephen R. Colgate

Assistant Attorney General

for Administration

U.S. Department of Justice

Room 1111

10th and Constitution Avenue, NW

Washington, DC 20530

Phone: 202-514-3101

Fax: 202-514-1778

Labor

Ms. Patricia W. Lattimore

Acting Assistant Secretary

for Administration and Management

U.S. Department of Labor

Room S-2514

200 Constitution Avenue, NW

Washington, DC 20210

Phone: 202-219-9086

Fax: 202-219-1270

National Aeronautics and

Space Administration

Mr. Jeffrey E. Sutton

Acting Associate Administrator for Management Systems and Facilities

National Aeronautics and Space Administration

Code J, Room 6W17

300 E Street, SW

Washington, DC 20546-0001

Phone: 202-358-2800

Fax: 202-358-3068

\section{Postal Service}

Mr. William Dowling

Vice President, Engineering

U.S. Postal Service

8403 Lee Highway

4th Floor

Merrifield, VA 22082-8101

Phone: 703-280-7001

Fax: 703-280-8401 $\underline{\text { State }}$

Mr. Patrick S. Kennedy

Assistant Secretary

for Administration

U.S. Department of State

Room 6330

22nd \& C Streets, NW

Washington, DC 20520

Phone: 202-647-1492

Fax: 202-647-1558

\section{Transportation}

Ms. Melissa Spillenkothen

Assistant Secretary for Administration

U.S. Department of Transportation

Room 10314

4007 th Street, SW

Washington, DC 20590

Phone: 202-366-2332

Fax: 202-366-9634

Treasury

Ms. Nancy Killefer

Assistant Secretary

for Management/Chief Financial Officer

U.S. Department of the Treasury

Room 2426, Main Treasury Building

1500 Pennsylvania Avenue, NW

Washington, DC 20220

Phone: 202-622-0410

Fax: 202-622-2337

\section{Veterans Affairs}

Dr. Thomas L. Garthwaite

Deputy Under Secretary for Health (10A)

U.S. Department of Veterans Affairs

Room 806

810 Vermont Avenue, NW

Washington, DC 20420

Phone: 202-273-5803

Fax: 202-273-7090

Office of Management and Budget

Dr. Kathleen Peroff

Deputy Associate Director

Energy and Science Division

Office of Management and Budget

New Executive Office Building

Room 8001

725 17th Street, NW

Washington, DC 20503

Phone: 202-395-3404

Fax: 202-395-4817 


\title{
APPENDIX G \\ PERSONNEL OF THE DEPARTMENT OF ENERGY'S \\ FEDERAL ENERGY MANAGEMENT PROGRAM
}

FY 1997 Personnel

\author{
Dan W. Reicher \\ Assistant Secretary, Energy Efficiency and Renewable Energy \\ and Chair, Federal Interagency \\ Energy Policy Committee
}

Federal Energy Management Program Staff:

John Archibald, Acting Director

Executive Secretary, Federal Interagency Energy Policy Committee, Executive Director, Interagency Energy Management Task Force

Veronica Bellamy

Ted Collins

Jerry Dion

Judy Florance

Curtis Framel

Mike Fulton

Nancy Hapstack

Louis Harris

Annie Haskins

Arun Jhaveri

April Johnson

Randy Jones

Paul King

Bill Klebous

Rick Klimkos
Katie-Kroehle

Helen Krupovich

Will Litner

Dean McCauley

Bob McLaren

Pat O'Brien

Vic Petrolati

Will Prue

Ernie Rios

Tanya Sadler

Cheri Sayer

Fred Singleton

Anne Sprunt Crawley

Tatiana Strainic Muessel

Nellie Tibbs 